\title{
REPEATABILITY AND UNCERTAINTY ANALYSES OF NASA/MSFC LIGHT GAS GUN TEST DATA
}

\author{
Dr. William P. Schonberg \\ Associate Professor \\ Civil and Environmental Engineering Department \\ David Cooper \\ Graduate Research Assistant \\ Mechanical and Aerospace Engineering Department \\ University of Alabama in Huntsville \\ Huntsville, Alabama 35899
}

FINAL REPORT

Contract NAS8-36955/D.0.74

\begin{abstract}
National Aeronautics and Space Administration George C. Marshall Space Flight Center
\end{abstract}

March 1993 


\section{ACKNOWLEDGMENTS}

The authors are grateful for support from the NASA/Marshall Space Flight Center under contract NAS8-36955, Delivery Order 74. The authors would like to acknowledge the assistance and guidance provided by the NASA/MSFC Technical Contracting Officer, Ms. Miria Finckenor (Engineering Physics Division, Physical Sciences Branch). The authors would like to express their appreciation to Mssrs. Jim Zweiner, Roy Taylor (ret.), Hubert Smith (ret.), and Joe Lambert (ret.) of the NASA/Marshall Space Flight Center Laboratory Support Branch, Mssrs. Phillip Petty and Robert Stowell of the Martin Marietta Corporation, and Mssrs. Mike Bjorkman, Ben Ramsey and Earl Shirley of the Boeing Corporation for conducting the impact testing that made this investigation possible. In addition, the authors are grateful to the NASA/MSFC Structural Development Branch (Structures Division) for providing support to the U.S. Army Corps of Engineers to perform the HULL code impact simulations that were analyzed in one of the Delivery Order tasks. Finally, the authors would like to express their gratitude to Dr. Hugh Coleman, Professor of Mechanical and Aerospace Engineering at the University of Alabama in Huntsville for his advice on matters pertaining to experimental repeatability and uncertainty analysis. 
Table of Contents

ACKNOWLEDGMENTS $\ldots \ldots \ldots \ldots \ldots \ldots \ldots \ldots \ldots \ldots \ldots \ldots \ldots \ldots \ldots \ldots \ldots \ldots$

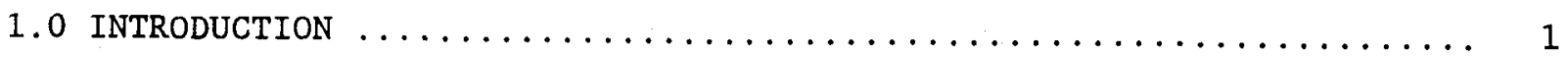

1.1 Background Information $\ldots \ldots \ldots \ldots \ldots \ldots \ldots \ldots \ldots \ldots \ldots \ldots$

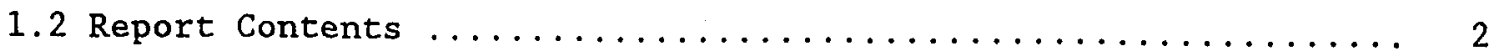

1.3 References $\ldots \ldots \ldots \ldots \ldots \ldots \ldots \ldots \ldots \ldots \ldots \ldots \ldots \ldots \ldots \ldots \ldots$

2.0 HYPERVELOCITY IMPACT TESTING AT THE NASA/MARSHALL

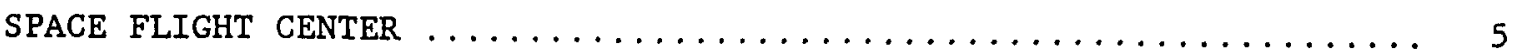

2.1 An Overview of NASA/MSFC Hypervelocity Impact Testing $\ldots . \ldots .5$

2.2 References $\ldots \ldots \ldots \ldots \ldots \ldots \ldots \ldots \ldots \ldots \ldots \ldots \ldots \ldots \ldots \ldots$

2.3 Summary of NASA/MSFC Hypervelocity Impact Test Shot

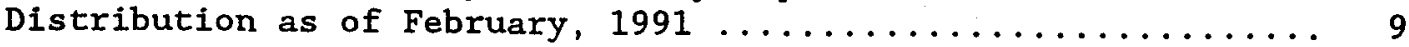

2.4 Detailed NASA/MSFC Hypervelocity Impact Test Shot

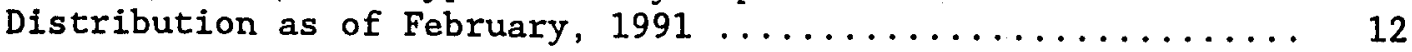

3.0 REPEATABILITY AND UNCERTAINTY ANALYSES $\ldots \ldots \ldots \ldots \ldots \ldots \ldots \ldots$

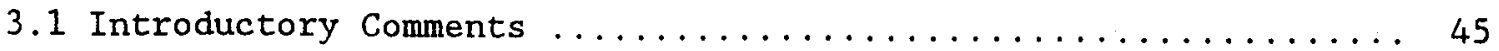

3.2 Concepts in Experimental Repeatability and

Unceratinty Analyses ........................ 45

3.3 Methodology $\ldots \ldots \ldots \ldots \ldots \ldots \ldots \ldots \ldots \ldots \ldots \ldots \ldots \ldots \ldots \ldots$

3.4 Results and Discussion - - Repeatability Analysis ......... 55

3.5 Results and Discussion - Uncertainty Analysis .......... 67

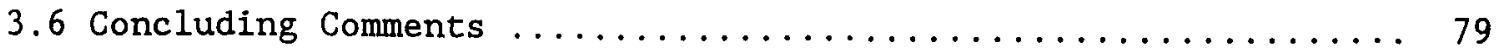

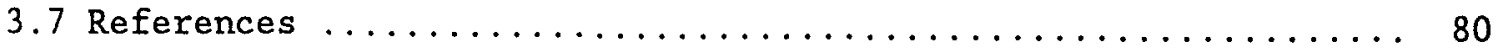

3.8 Uncertainty Analysis Test Data $\ldots \ldots \ldots \ldots \ldots \ldots \ldots \ldots \ldots \ldots$ 
4.0 CONCLUSIONS AND RECOMMENDATIONS $\ldots \ldots \ldots \ldots \ldots \ldots \ldots \ldots \ldots$

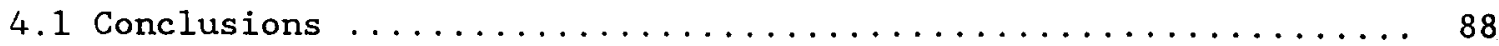

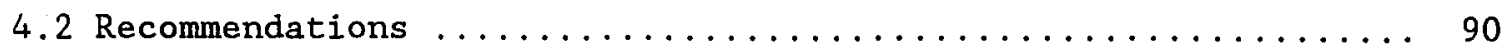

APPENDIX I $\ldots$ PHASE $C / D$ TESTING PARAMETER DATABASE $\ldots \ldots \ldots \ldots \ldots \ldots \ldots$

APPENDIX II - PHASE $\mathrm{C} / \mathrm{D}$ TESTING DAMAGE DATABASE $\ldots \ldots \ldots \ldots \ldots \ldots$ 


\subsection{INTRODUCTION}

\subsection{Introductory Comments}

Al1 large spacecraft are susceptible to impacts by meteoroids and pieces of orbiting space debris. These impacts occur at extremely high speeds and can damage flight-critical systems, which can in turn lead to catastrophic failure of the spacecraft. Numerous impact craters have been found on Space Shuttle Orbiter windows and on the Shuttle's heat resistant tiles while a preliminary examination of the recently recovered LDEF satellite revealed tens of thousands of craters, pits, and holes. While it is not precisely known how many of these are due to orbital debris impacts and how many are due to meteoroid impacts, the susceptibility of earth-orbiting spacecraft to high-speed impacts is clearly evident. Naturally, the susceptibility of such spacecraft increases with increased mission duration. Therefore, the design of a spacecraft for a long-duration mission must take into account the possibility of such impacts and their effects on the spacecraft structure and on all of its exposed subsystem components.

One of the ways to obtain information on the response of a structure to a meteoroid impact or an orbital debris impact is to simulate the impact conditions of interest and analyze the resulting damage to a target structure. Hypervelocity impact testing began at the NASA/Marshall Space Flight Center in 1964 with the installation of a light gas gun in what is now known as the Materials and Processes Laboratory. The initial need and function of the facility was to provide a means of simulating meteoroid impacts on spacecraft and to provide the data required to determine the perforation probability of candidate spacecraft wall designs by such impacts. In the 1970 's, the interest in testing for protection against meteoroid impacts 
declined. However, the increased launch activity in recent years has renewed interest in high speed impact testing at the NASA/MSFC facility and at other such facilities around the world. The attention of this new wave of testing has been focused on mitigating the threat posed by orbital debris particle impacts.

\subsection{Report Contents}

This Final Report presents an overview of the impact tests performed at NASA/MSFC in the time period 1985 to 1991 and the results of phenomena repeatability and data uncertainty studies performed using the information obtained from those tests. An analysis of the data from over 400 tests conducted between 1989 and 1991 was performed to generate a database to supplement the Hypervelocity Impact Damage Database developed under a previous effort [1.1]. The database in Reference [1.1] contains the results of 540 high speed impact tests performed at the NASA/MSFC between 1985 and 1989.

In addition to the repeatability and uncertainty studies described herein, the analyses performed during the course of this study included the following tasks:

1) a study of the effects of internal module wall pressure on perforation resistance $[1.2]$;

2) a study the effects of MLI thickness and placement within a dualwall system [1.3];

3) a study of the differences in perforation resistance of aluminum 2219-T87 and 5456-H116 under similar impact conditions [1.4]; and,

4) a comparison of HULL code predictions with experimental results for dual-wall structures under hypervelocity projectile impact $[1.5,1.6,1.7]$. 
The supplemental database developed as part of this investigation consists of two parts. The first part contains the geometric, material, and impact parameters for each test, including test number, projectile velocity, diameter, material, and shape, trajectory obliquity, bumper plate material and thickness, pressure wall plate material and thickness, the thickness and location of MLI (if applicable), and the total stand-off distance between the bumper and pressure wall plate. The second part contains a summary of the damage sustained by the impact targets, including bumper plate hole dimension(s), whether or not the pressure wall was perforated or spalled, the equivalent pressure wall single hole diameter (if applicable), the diameter of the three largest perforated holes in the pressure wall plate (if applicable), the depth of the three deepest craters on the pressure wall plate and corresponding surface diameters, the total area of front-surface pressure wall plate damage, and the total area of rear-side pressure wall spall (if applicable).

The next section presents an overview of hypervelocity impact testing that has been done at NASA/MSFC since 1985. Section 3.0 presents the results of the repeatability and uncertainty studies; conclusions and recommendations for future work are presented in Section 4.0. Complete printouts of the supplemental parameter and damage databases can be found in Appendix I and II, respectively, at the end of this report. The names of the LOTUS files in which the data in Appendix I and II can be found on the accompanying floppy disk is also provided. 


\subsection{References}

1.1 Schonberg, W.P., Bean, A.J., and Darzi, K., Hypervelocity Impact Physics, NASA CR-4343, January, 1991.

1.2 Schonberg, W.P., "Effect of Internal Stress Fields on the Perforation Resistance of Dual-Wall Structures Under Hypervelocity Impact", Incernational Journal of Impact Engineering, in press, 1992.

1.3 Schonberg, W.P., "Effect of Multi-Layer Thermal Insulation Thickness and Location on the Hypervelocity Impact Response of Dual-Wall Structures", submitted for publication consideration, Acta Astronautica, 1993.

1.4 Schonberg, W.P., "Aluminum 2219-T87 and 5456-H116: A comparative Study of Pressure Wall Materials in Dual-Wall Structures Under Hypervelocity Impact", Acta Astronautica, Vol. 26, No. 11, pp. 799-812, 1992.

1.5 Schonberg, W.P., and Peck, J.A., "HULL Code Prediction of Multi-Wall Structural Response to Hypervelocity Projectile Impact", International Journal of Impact Engineering, in press, 1992.

1.6 Schonberg, W.P., and Peck, J.A., "Paramteric Investigation of Multi-Wall Structural Response to Hypervelocity Cylindrical Projectile Impact", Computers and Structures, submitted for publication, 1992.

1.7 Schonberg, W.P., Predicting Multi-Wall Structural Response to Hypervelocity Impact Using the HULL Code, NASA CR-4486, January, 1993. 


\subsection{HYPERVELOCITY IMPACT TESTING AT THE NASA/MARSHALL SPACE FLIGHT CENTER}

\subsection{An Overview of Hypervelocity Impact Testing at NASA/MSFC}

Orbital debris impact testing began at NASA/MSFC in July, 1985 at the Space Debris Simulation Facility of the Materials and Processes Laboratory at the NASA/Marshall Space Flight Center. The facility consists of an instrumented two-stage light gas gun capable of launching $2.5 \mathrm{~mm}$ to $12.7 \mathrm{~mm}$ projectiles at velocities of 2 to $8 \mathrm{~km} / \mathrm{sec}$. Projectile velocity measurements are accomplished via pulsed X-ray, laser diode detectors, and a Hall photographic station. For a detailed description of the gun and its instrumentation, the reader is referred to Reference $[2.1]$.

As part of the Phase $B$ development activities for the Space Station Freedom, 540 impact tests were performed using the NASA/MSFC light gas gun through March 1989; an additional 410 were performed as part of the Phase C/D activities through February 1991. Testing has been focused primarily on multi-wall target structures that were designed to simulate possible space Station module wall Configurations. These target systems consisted of 'bumper', 'pressure wall', and 'witness' plates and multi-layer thermal insulations (MLI). The parameters of the tests, as well as the results of the Phase B damage analyses, can be found in Reference [2.2].

In the Phase C/D tests, aluminum projectiles ranging in diameter from $3.175 \mathrm{~mm}$ to $9.53 \mathrm{~mm}$ were fired at velocities ranging from approximately 2 to $8 \mathrm{~km} / \mathrm{sec}$. The target structures consisted primarily of aluminum plates of various thicknesses and spaced apart at various distances. Tests were performed with and without multi-layer insulation (MLI) of various thicknesses and at various positions within the spacing between the bumper plate and the pressure wall plate in the test specimens. Although the majority of the 
testing was performed normal to the plane of the target, a significant number of oblique impact tests was performed as well. A general summary of the Phase $B$ and Phase C/D tests is presented in Section 2.3 where test shots are grouped in broad categories such as Impact Obliquity, Configuration, and Stand-off Distance. Examination of the information in these tables reveals several features about NASA/MSFC impact testing through February 1991.

1) The number of tests conducted at impact velocities in excess of 7 $\mathrm{km} / \mathrm{sec}$ is relatively small - only approximately $12.7 \%$ of all the tests conducted were in this impact velocity regime.

2) Only a few shots (approximately $2.9 \%$ of all the tests conducted) have been fired using very large projectiles (i.e. greater than $1 \mathrm{~cm}$ in diameter).

3) of the 950 total tests in Phase B and Phase C/D, approximately $57.3 \%$ were fired normal to the plane of the target and and only $16.1 \%$ were conducted at trajectory obliquities at or above $60^{\circ}$.

4) Nearly $82.9 \%$ of the impact tests through February 1991 have been performed on single bumper all-aluminum target structures.

5) All but 16 of the tests through February 1991 (i.e. approximately 98.3\%) have been performed using spherical projectiles.

Section 2.4 contains a series of charts that detail the distribution of all the single bumper tests performed through February 1991. Only single bumper testing was considered in the development of these charts because of the scarcity of multi-bumper testing and the increased number and complexity 
of test parameters that describe such test shots. The test and configuration parameters for the single bumper shots are defined on the first page of Section 2.4. Any deviations from these baseline parameters are signified with footnotes, a legend for which is also provided in Section 2.4.

The test distribution charts in Section 2.4 categorize the test shots according to the presence of MLI, the projectile diameter D (in inches), the impact velocity $\mathrm{V}$ (in $\mathrm{km} / \mathrm{sec}$ ), and the thickness of the bumper plate (in inches). The number in the upper right hand corner of these charts is a number that identifies the impact obliquity, velocity range, and spacing for the test shots in a particular chart. For example, the number 45V23S4 implies that the test shots in that chart were all fired at 45 degrees with velocities between 2 and $3 \mathrm{~km} / \mathrm{sec}$ and that the target was a single bumper specimen with a stand-off distance of 4 inches (approximately $10 \mathrm{~cm}$ ).

It is noted that the charts in Section 2.4 contain the distribution of the Phase $C / D$ tests as well as the Phase $B$ tests. The Phase $C / D$ tests can be distinguished from the Phase $B$ tests by the different numbering systems used in the two test phases. The Phase $C / D$ tests all begin with four numbers followed by a letter or a dash and another number; all other tests are Phase $B$ tests. From these test distribution charts, it is evident that many gaps still exist in the current NASA/MSFC test database. These charts can be used as a guide in the selection of impact parameters for future hypervelocity impact test programs. Specific recommendations are presented in Section 4.2 . 


\subsection{References}

2.1 Taylor, R.A., "A Space Debris Simulation Facility for Spacecraft Materials Evaluation", SAMPE Quarterly, Vol. 18, No. 2, 1987, pp. 28-34.

2.2 Schonberg, W.P., Bean, A.J., and Darzi, K., Hypervelocity Impact Physics, NASA CR-4343, January, 1991. 
Section 2.3

Summary of NASA/MSFC Hypervelocity Impact Testing

Through February, 1991 
Number of Tests Performed

\begin{tabular}{|c|c|c|c|c|}
\hline & & Phase B & Phase $C / D$ & Combined \\
\hline Velocity $(\mathrm{km} / \mathrm{sec})$ & $\begin{array}{l}7.0 \leq \mathrm{V}<8.0^{+} \\
6.0 \leq \mathrm{V}<7.0 \\
5.0 \leq \mathrm{V}<6.0 \\
4.0 \leq \mathrm{V}<5.0 \\
3.0 \leq \mathrm{V}<4.0 \\
2.0 \leq \mathrm{V}<3.0 \\
1.0 \leq \mathrm{V}<2.0\end{array}$ & $\begin{array}{r}61 \\
165 \\
94 \\
103 \\
85 \\
31 \\
1 \\
540\end{array}$ & $\begin{array}{r}60 \\
137 \\
82 \\
57 \\
60 \\
14 \\
0 \\
410\end{array}$ & $\begin{aligned} & 121(12.7 \%) \\
& 302(31.8 \%) \\
& 176(18.5 \%) \\
& 160(16.8 \%) \\
& 145(15.3 \%) \\
& 45(4.8 \%) \\
& 1(0.1 \%) \\
& 950(100 \%)\end{aligned}$ \\
\hline Diameter $(\mathrm{cm})$ & $\begin{array}{l}1.00 \leq \mathrm{D} \leq 1.25 \\
0.75 \leq \mathrm{D}<1.00 \\
0.50 \leq \mathrm{D}<0.75 \\
0.25 \leq \mathrm{D}<0.50\end{array}$ & $\begin{array}{r}16 \\
218 \\
200 \\
106 \\
540\end{array}$ & $\begin{array}{r}12 \\
173 \\
137 \\
88 \\
410\end{array}$ & $\begin{aligned} & 28(2.9 \%) \\
& 391(41.1 \%) \\
& 337(35.5 \%) \\
& 194(20.5 \%) \\
& 950(100 \%)\end{aligned}$ \\
\hline Obliquity (deg.) & $\begin{array}{r}0^{\circ} \\
15^{\circ} \\
25^{\circ} \\
30^{\circ} \\
45^{\circ} \\
55^{\circ} \\
60^{\circ} \\
65^{\circ} \\
75^{\circ}\end{array}$ & $\begin{array}{r}337 \\
1 \\
1 \\
11 \\
128 \\
3 \\
10 \\
44 \\
5 \\
540\end{array}$ & $\begin{array}{r}207 \\
0 \\
0 \\
11 \\
99 \\
0 \\
40 \\
20 \\
33 \\
410\end{array}$ & $\begin{aligned} 544 & (57.3 \%) \\
1 & (0.1 \%) \\
1 & (0.1 \%) \\
22 & (2.3 \%) \\
227 & (23.8 \%) \\
3 & (0.3 \%) \\
40 & (5.3 \%) \\
64 & (6.7 \%) \\
38 & (4.1 \%) \\
950 & (100 \%)\end{aligned}$ \\
\hline Configuration & $\begin{array}{l}\text { Single Wall } \\
1 \text { Bumper } \\
2 \text { Bumpers } \\
3 \text { Bumpers } \\
4 \text { Bumpers } \\
6 \text { Bumpers } \\
\text { Windows } \\
\text { Bottles }\end{array}$ & $\begin{array}{r}11 \\
396 \\
89 \\
6 \\
3 \\
1 \\
26 \\
8 \\
540\end{array}$ & $\begin{array}{r}0 \\
392 \\
13 \\
5 \\
0 \\
1 \\
0 \\
8 \\
410\end{array}$ & $\begin{aligned} 11 & (1.1 \%) \\
788 & (82.9 \%) \\
102 & (10.7 \%) \\
11 & (1.1 \%) \\
3 & (0.3 \%) \\
1 & (0.1 \%) \\
26 & (2.8 \%) \\
8 & (1.0 \%) \\
950 & (100 \%)\end{aligned}$ \\
\hline$\frac{\text { Stand-Off Distance }}{\frac{\text { (Single Bumper) }}{}}$ & $\begin{array}{l}10.16 \mathrm{~cm} \\
15.24 \mathrm{~cm} \\
17.78 \mathrm{~cm} \\
20.32 \mathrm{~cm} \\
30.48 \mathrm{~cm} \\
40.64 \mathrm{~cm}\end{array}$ & $\begin{array}{r}334 \\
52 \\
1 \\
3 \\
5 \\
1 \\
396\end{array}$ & $\begin{array}{r}333 \\
11 \\
0 \\
0 \\
48 \\
0 \\
410\end{array}$ & $\begin{aligned} 667 & (84.6 \%) \\
63 & (8.0 \%) \\
1 & (0.1 \%) \\
3 & (0.3 \%) \\
53 & (6.8 \%) \\
1 & (0.1 \%) \\
950 & (100 \%)\end{aligned}$ \\
\hline
\end{tabular}




$\begin{array}{clr}\text { Miscellaneous } & \text { Cadmium Bumpers } & 10 \\ \text { (Totals) } & \text { Cadmium Projectiles } & 10 \\ & \text { Composite Bumpers } & 45 \\ & \text { Corrugated Bumpers } & 11 \\ & \text { Non-1100 Projectiles } & 36 \\ & \text { Cylindrical Projectiles } & 16 \\ & \text { Non-2219 Walls } & 48 \\ & \text { Non-Standard MLI } & 4 \\ & \text { Stressed Pressure Walls } & 34 \\ & \text { MLI on Bumper } & 11 \\ & \text { MLI 0.635 cm off Bumper } & 148 \\ & \text { MLI 5.08 cm off Bumper } & 21\end{array}$


Section 2.4

Detailed NASA/MSFC Hypervelocity Impact Test Shot Distribution Through February, 1991 


\section{BASELINE PARAMETERS}

Pressure Wall Thickness ... 0.125 in.

Stand-Off Distance .....4.0 in.

Number of Bumper Plates ... I

Projectile Shape ........ Sphere

Projectile Material ....... Al 1100

Bumper Plate Material ..... A1 6061-T6

Pressure Wall Material ... Al 2219-T87

MLI Thickness ........ 30 1ayers

MLI Materials ......... Kapton $/ \beta$-cloth

MLI Location ........... On Pressure Wall

IDENTIFICATION CODE: $\quad 45 \mathrm{~V} 23 \mathrm{~S} 4$

$$
\underset{\theta=45^{\circ} \mid}{\mid S=4 i n}
$$




\section{FOOTNOTES}

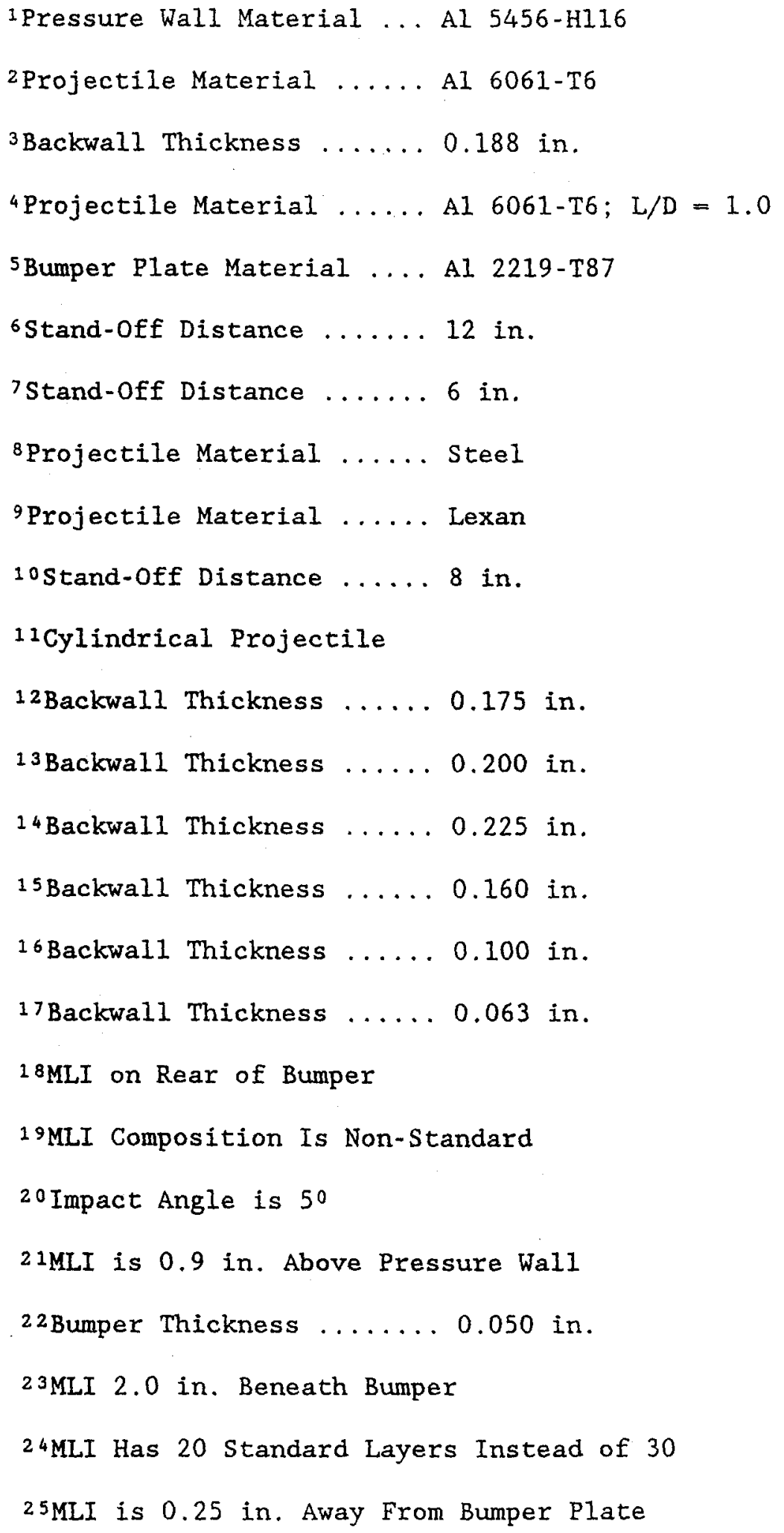




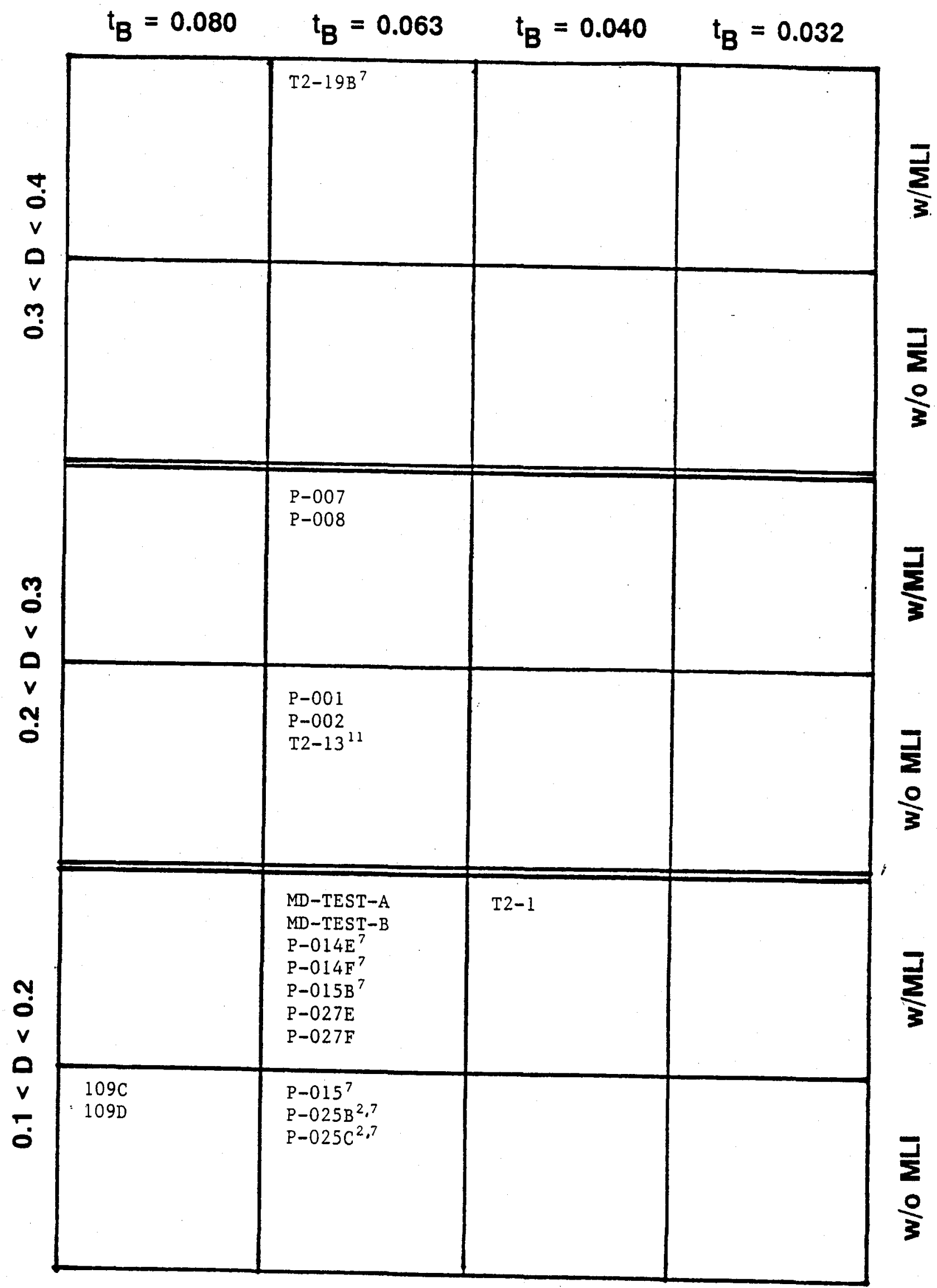




$$
t_{B}=0.080 \quad t_{B}=0.063 \quad t_{B}=0.040 \quad t_{B}=0.032
$$
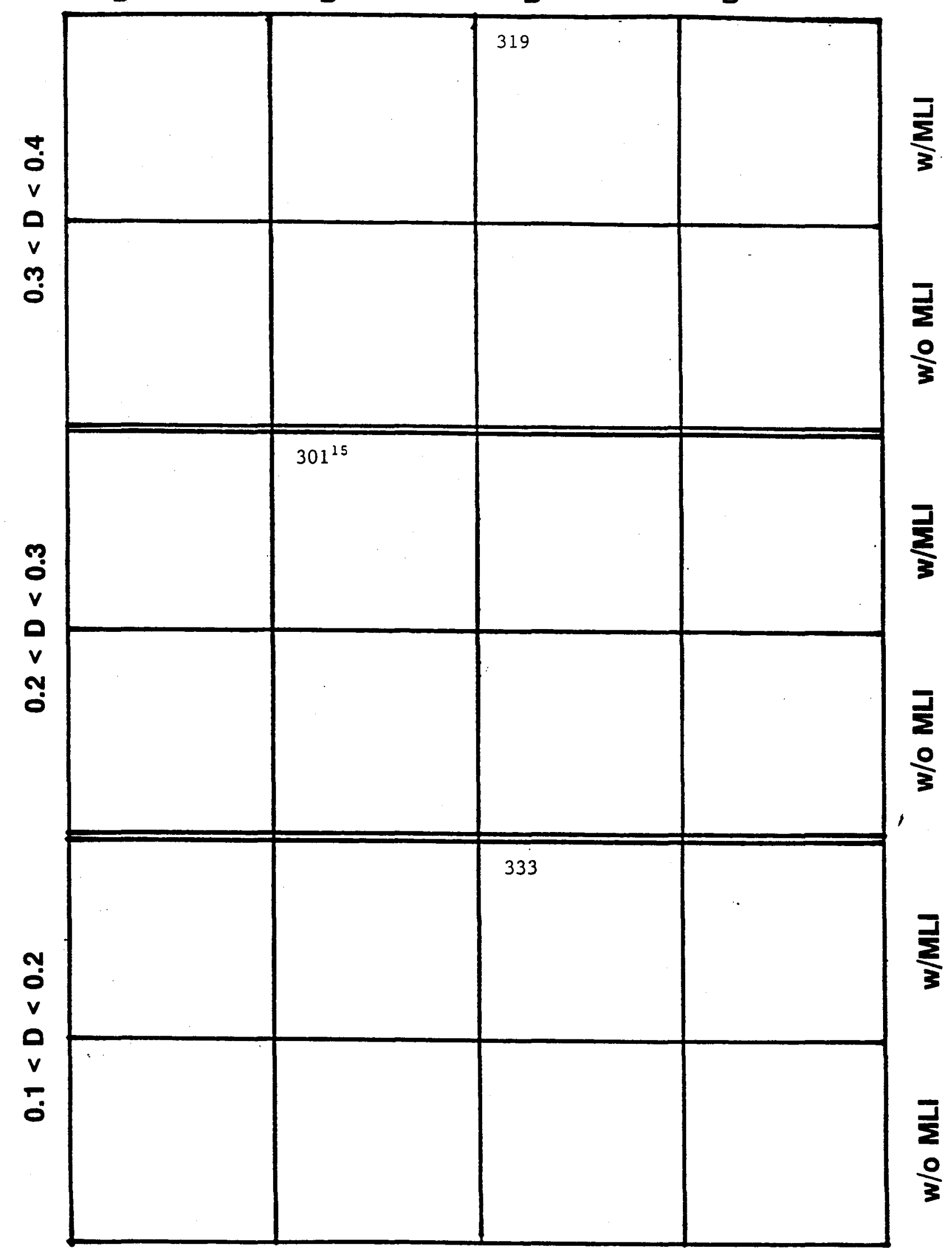


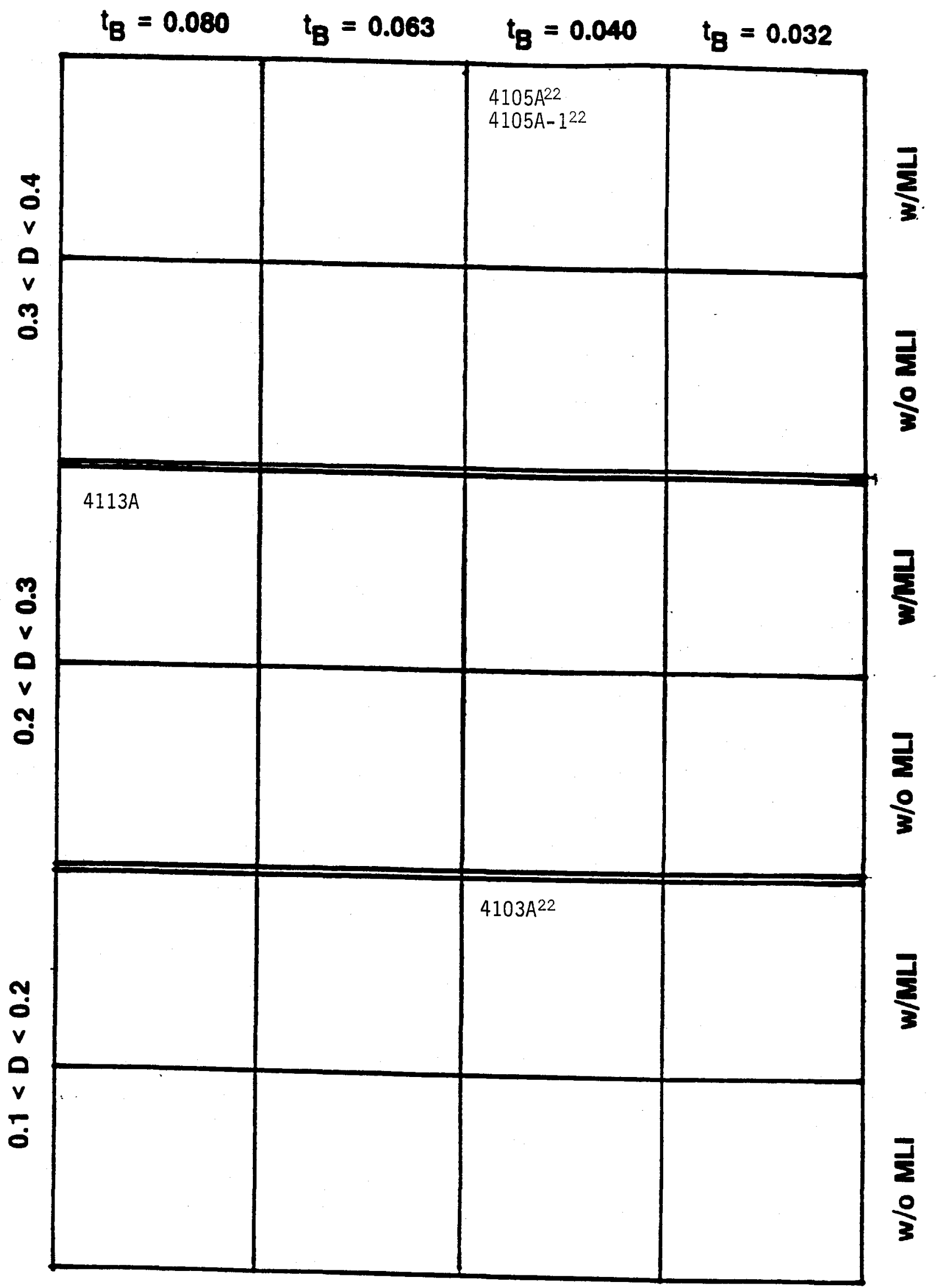




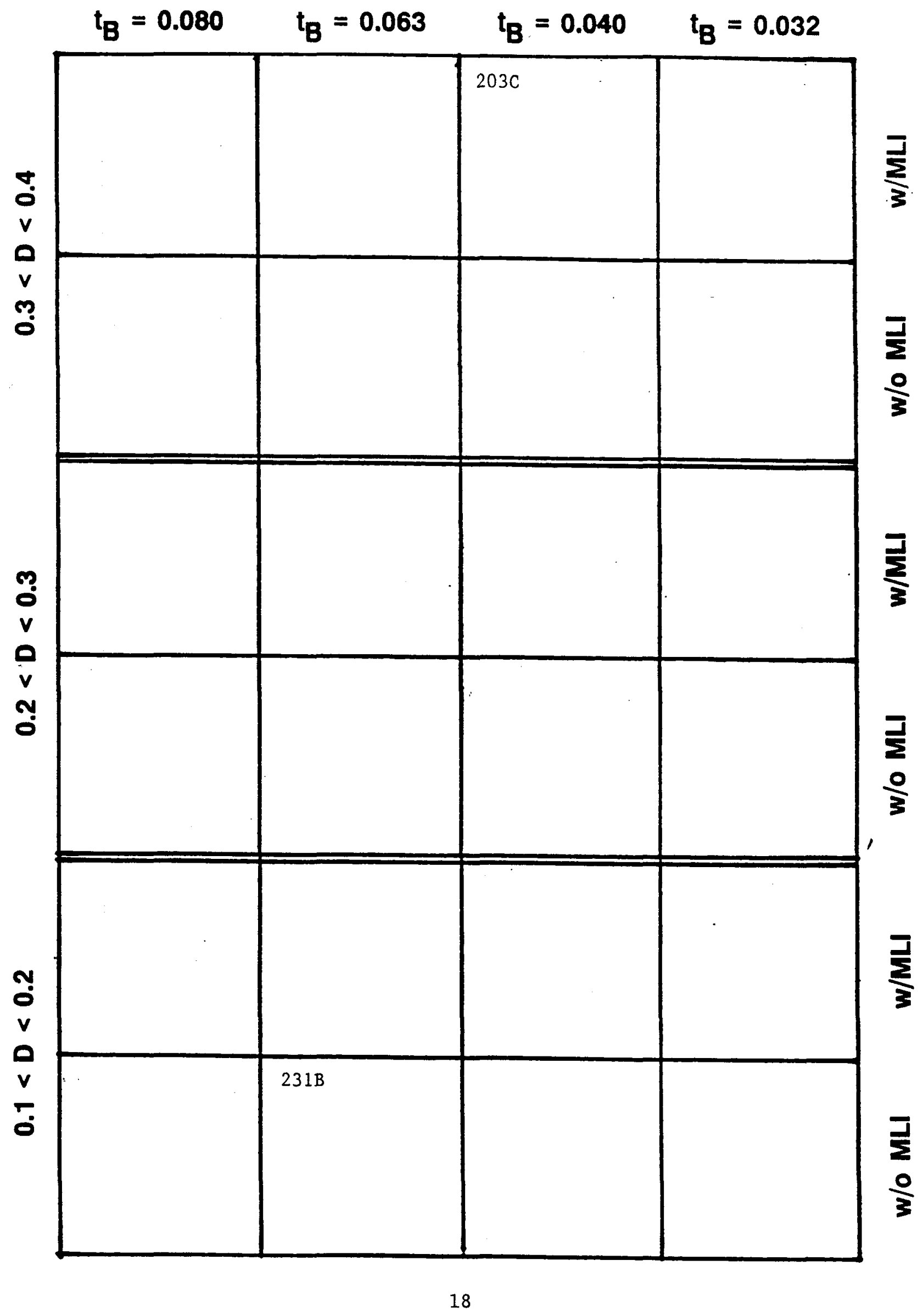




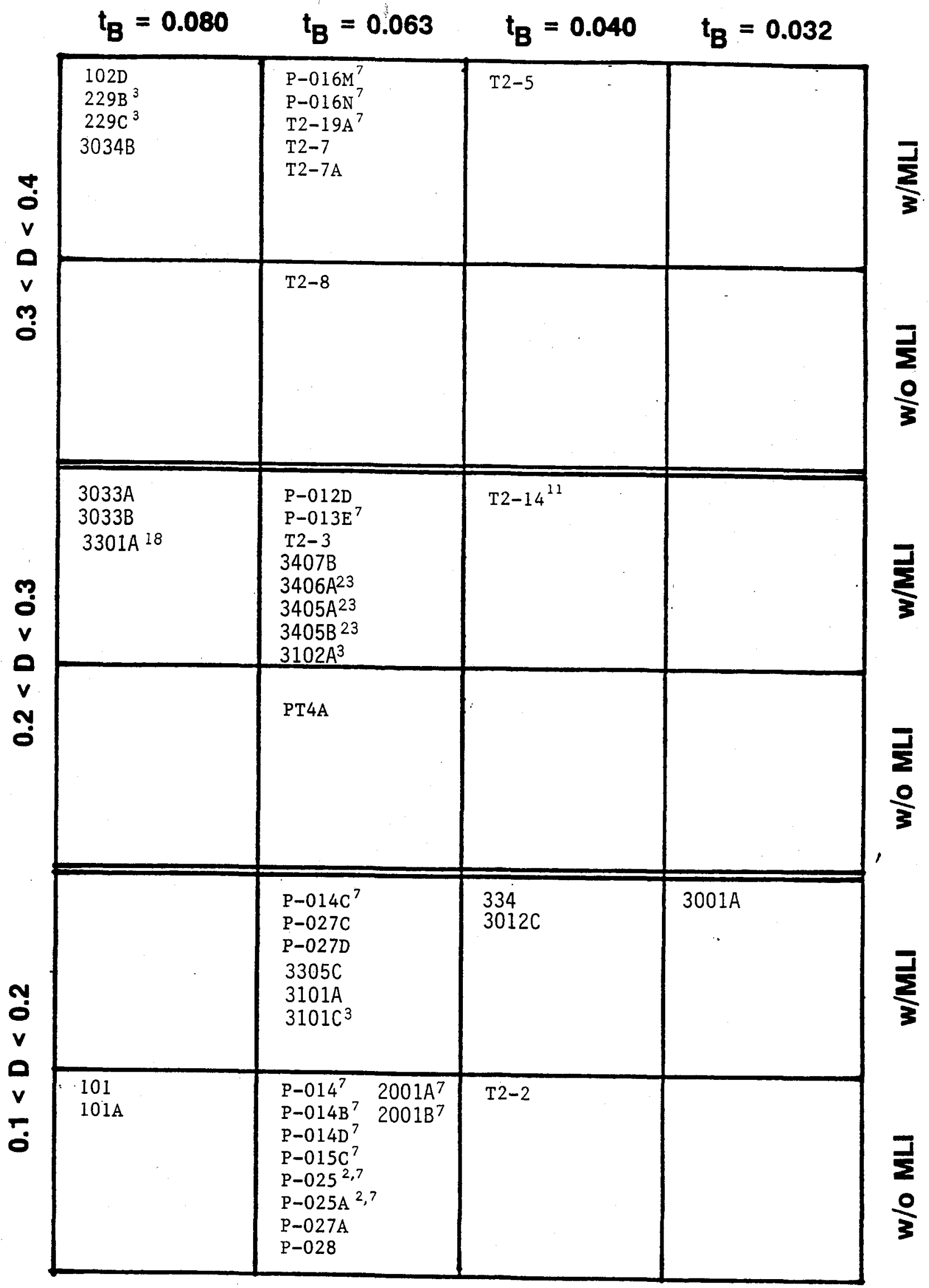




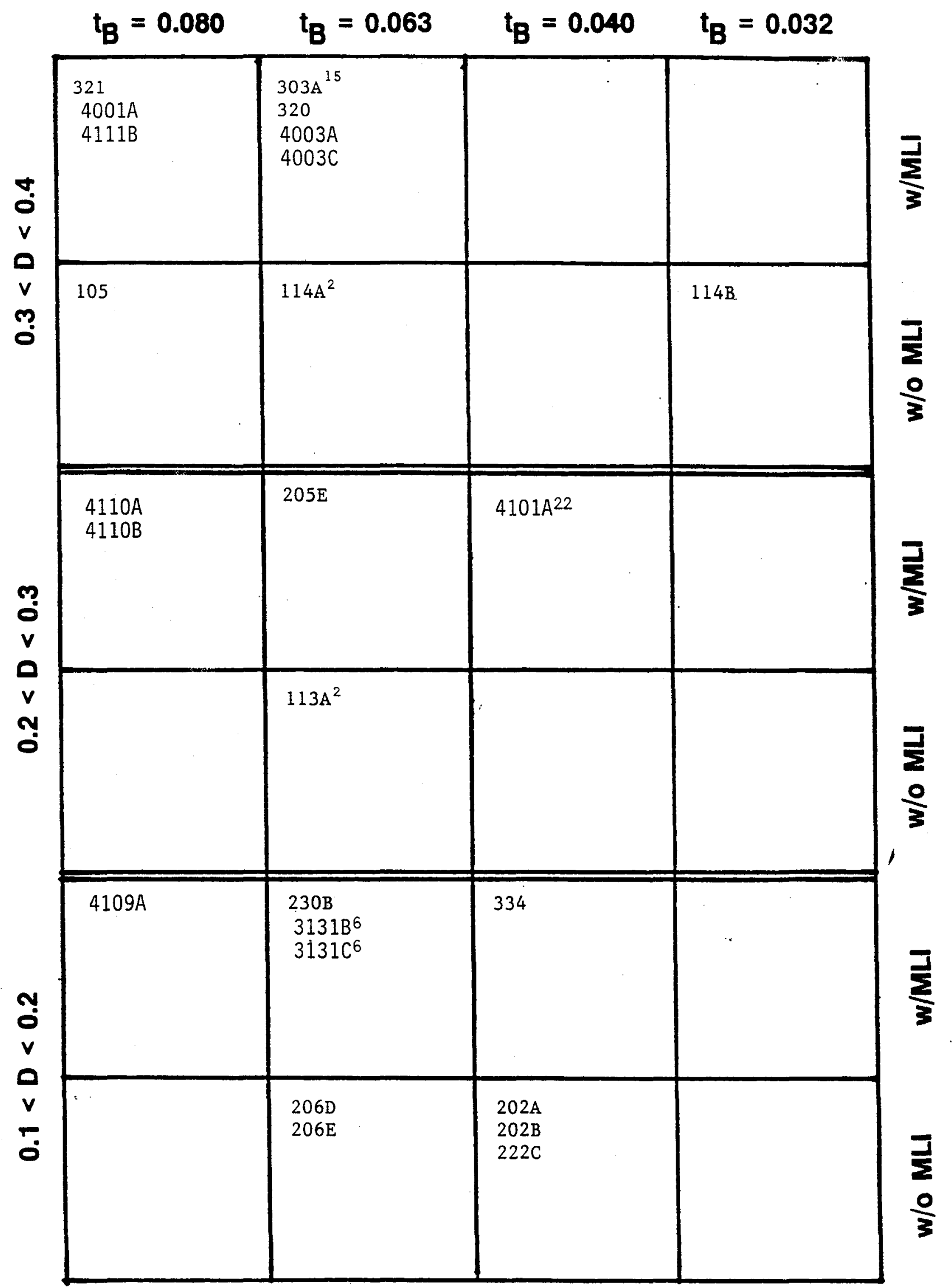




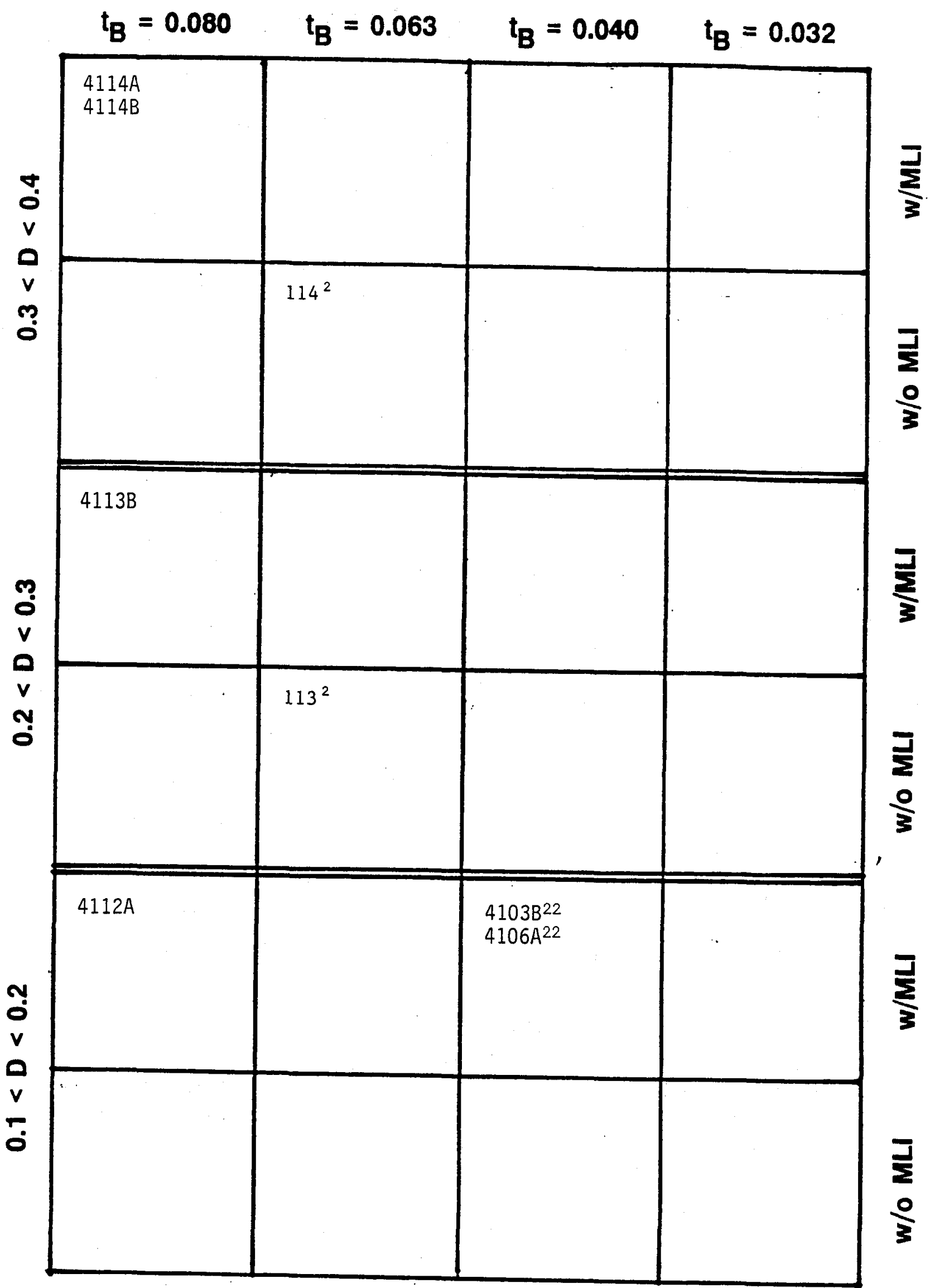




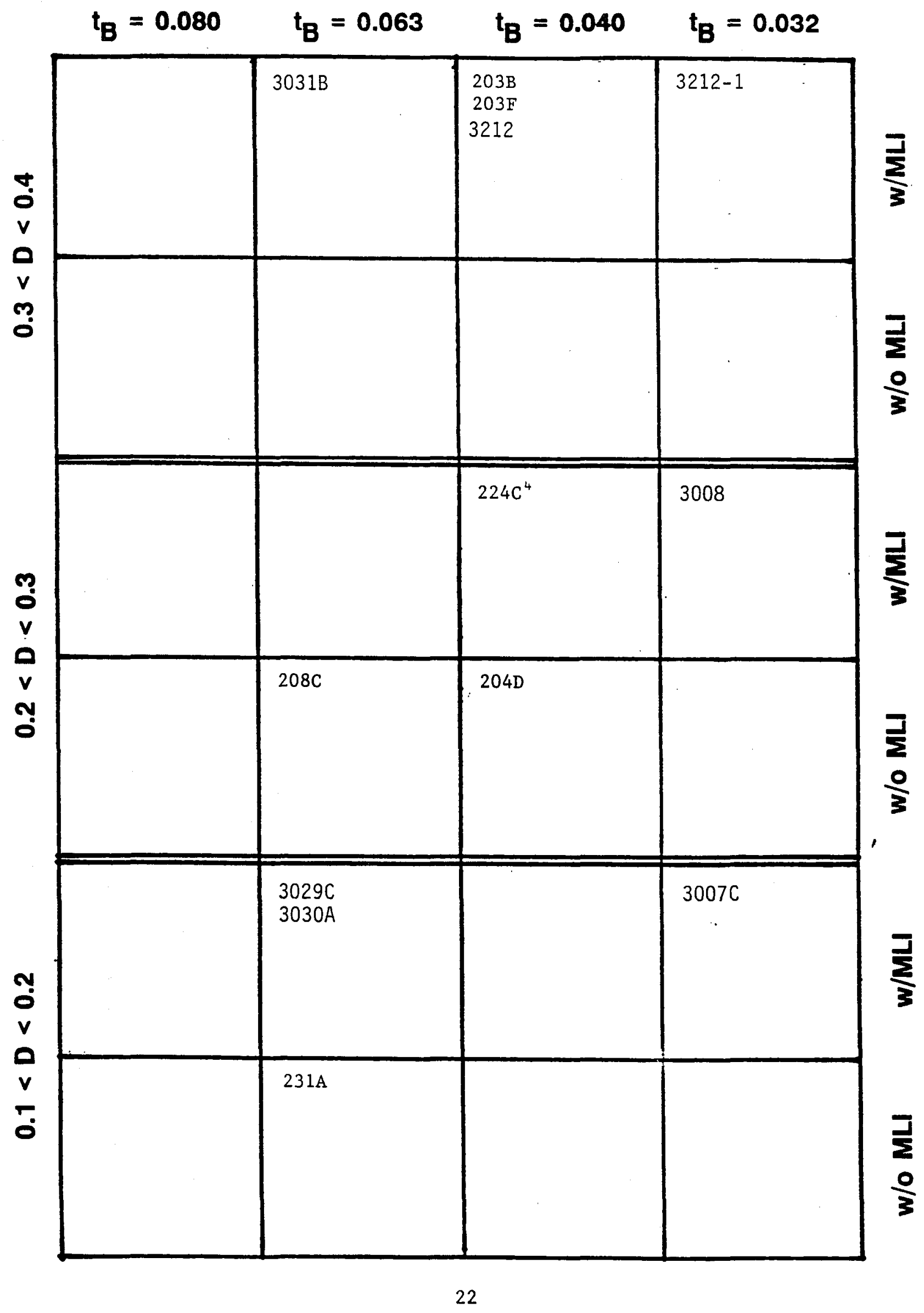




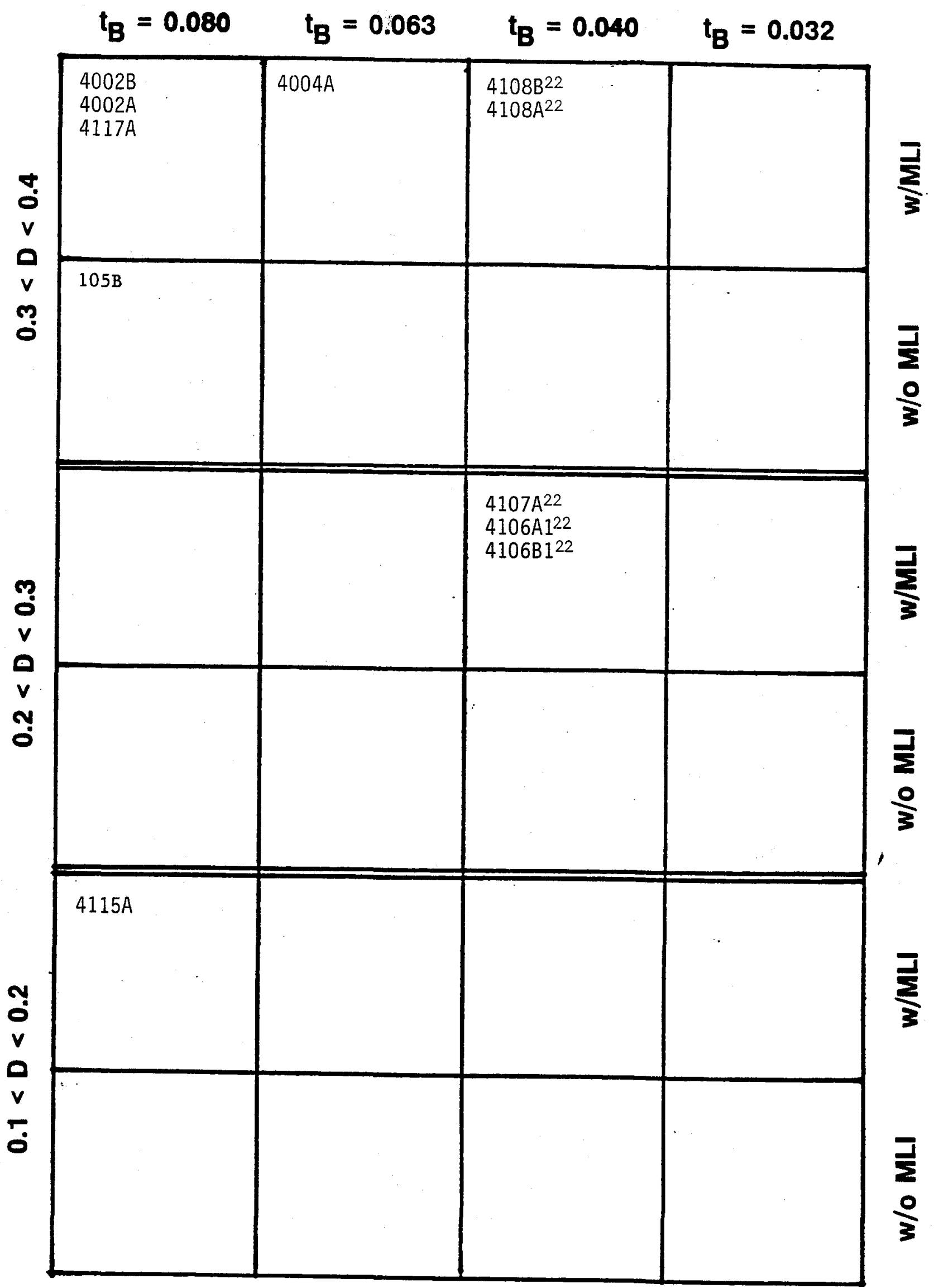




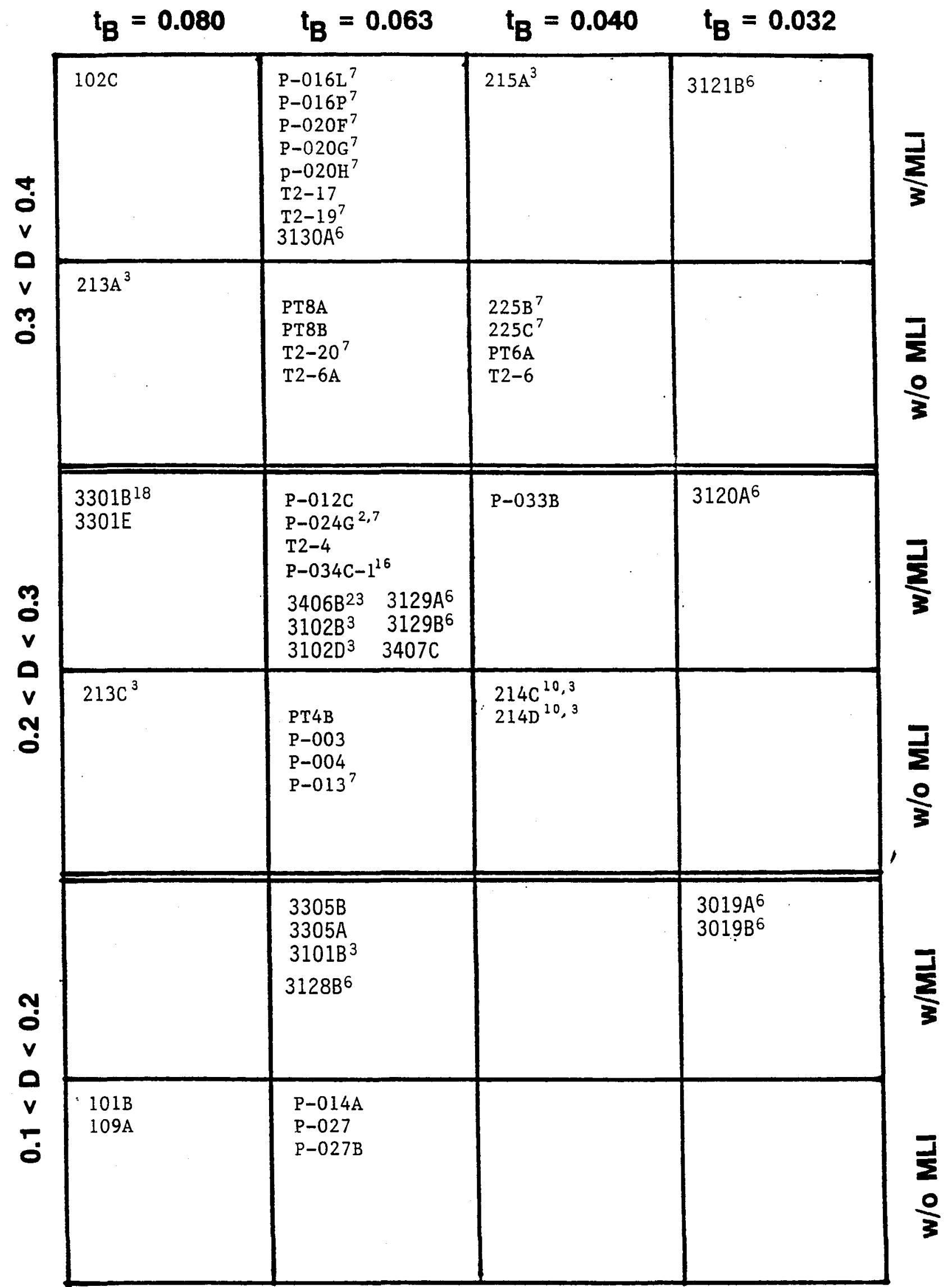




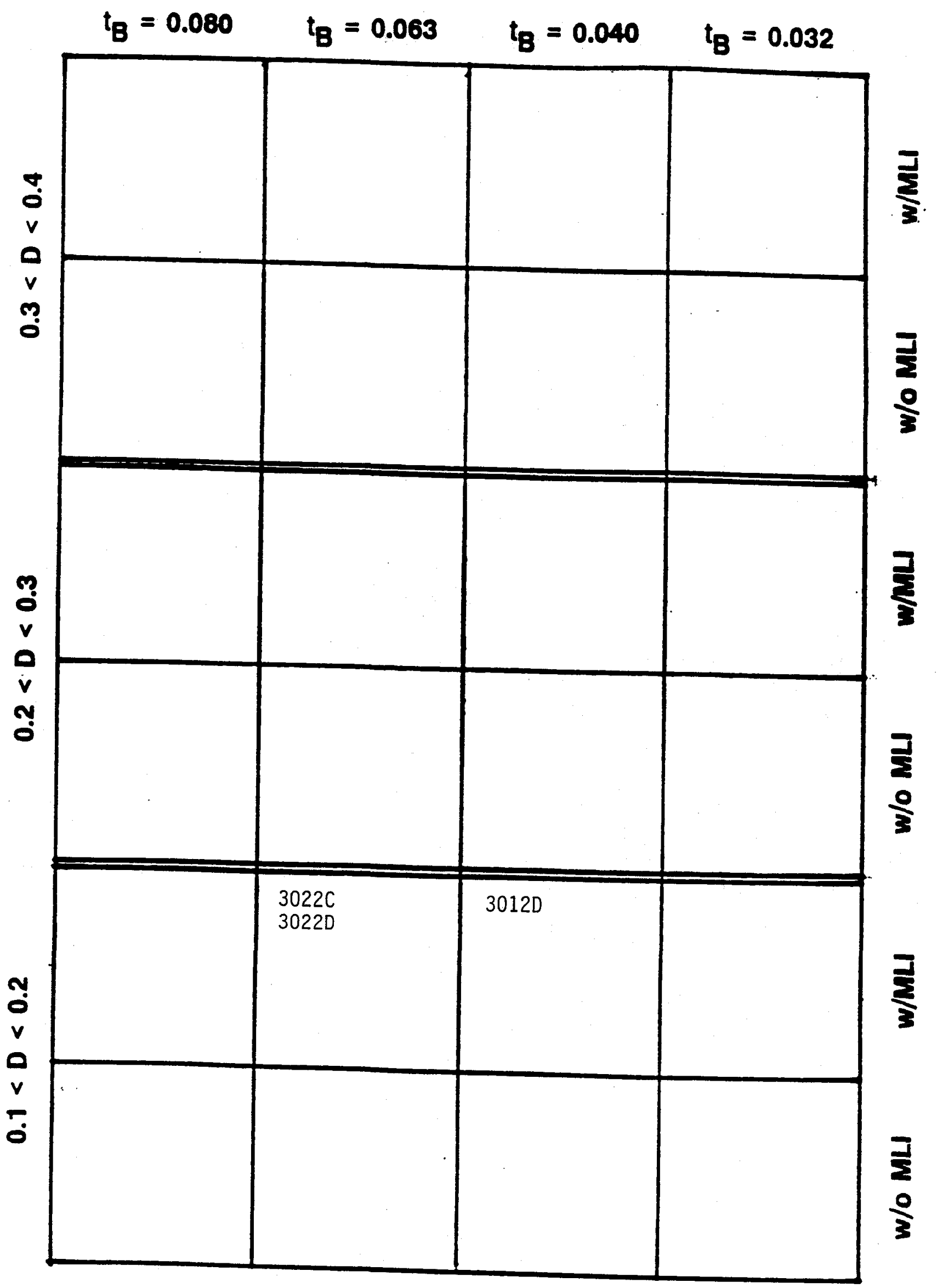




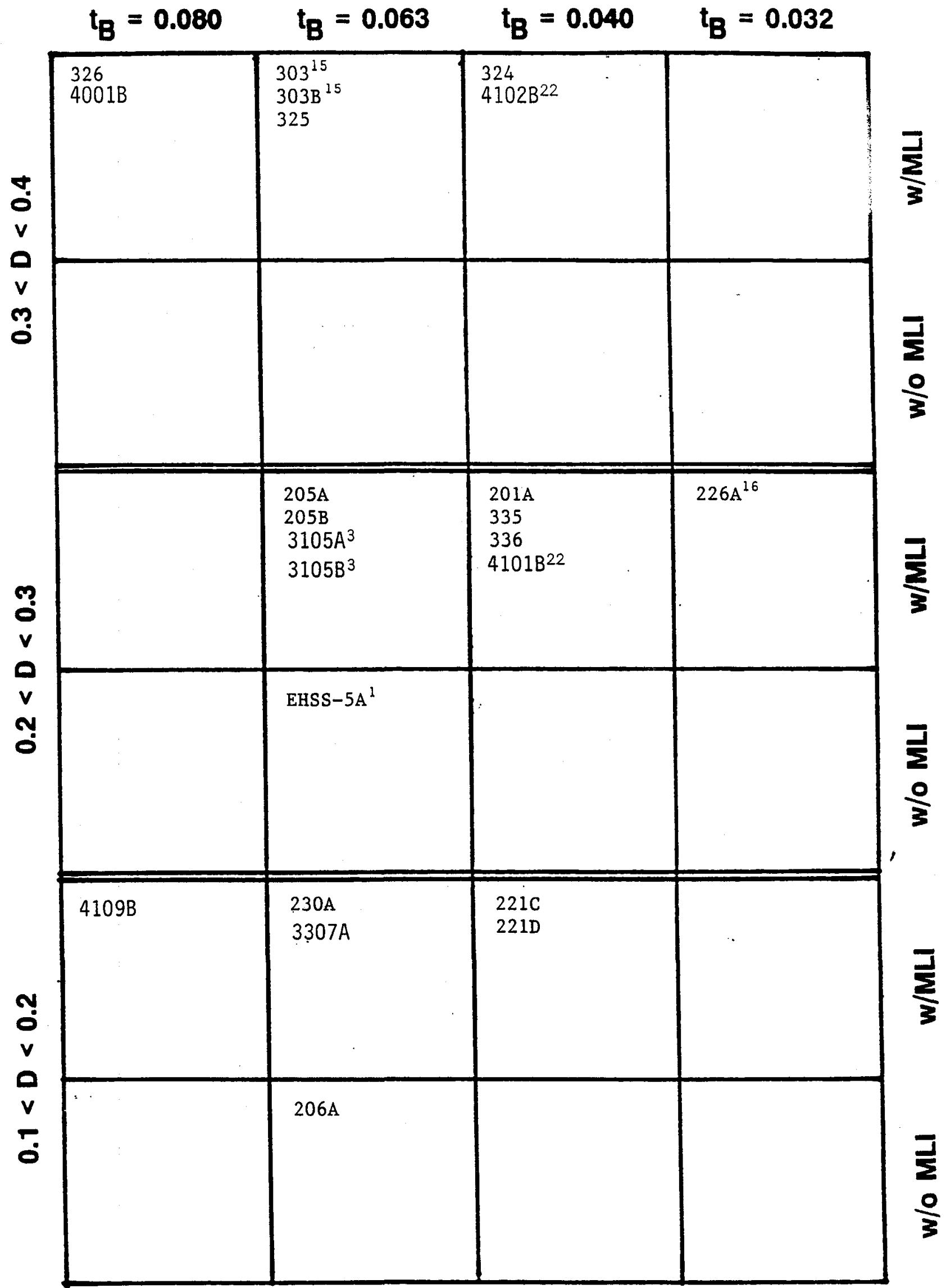




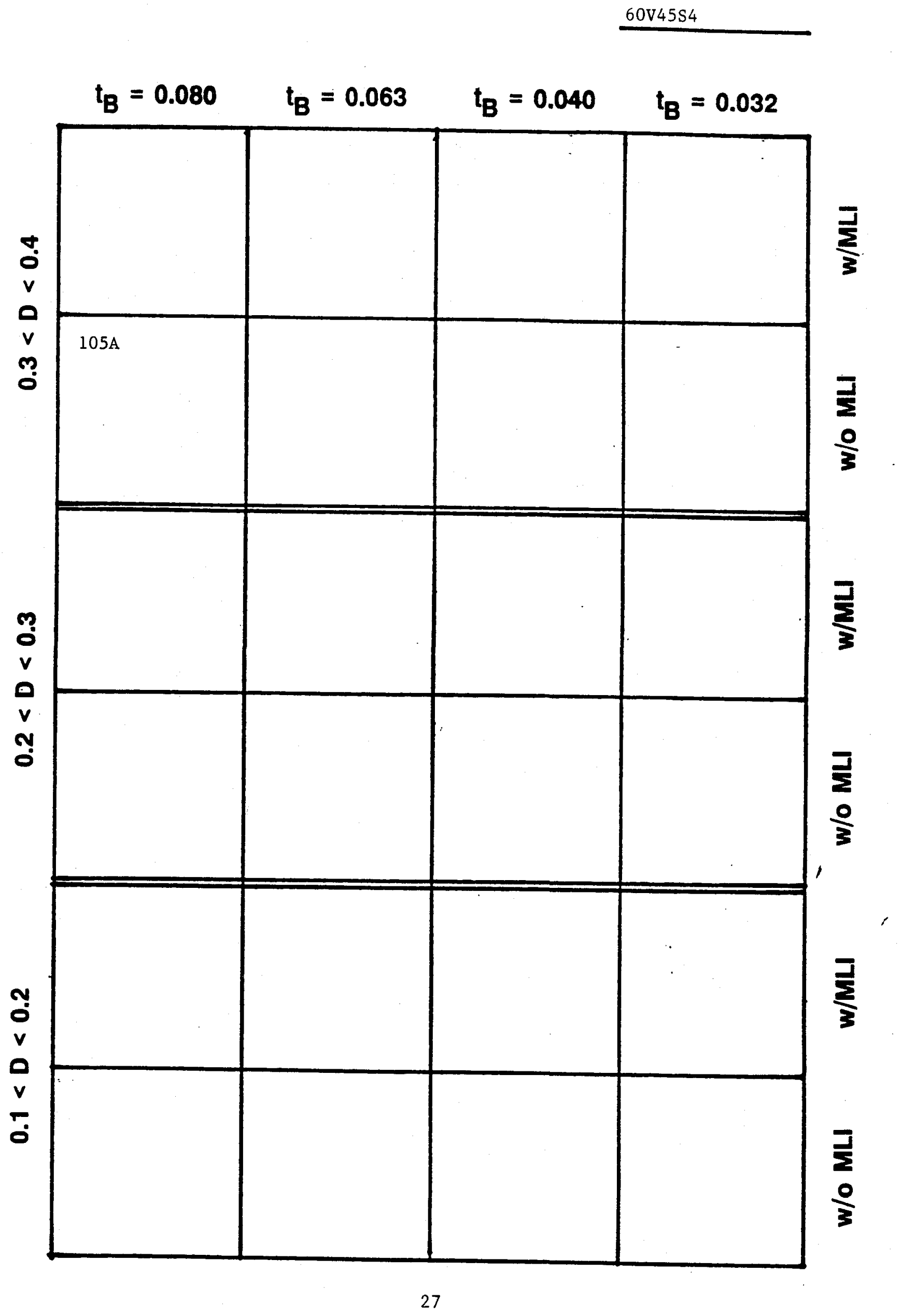




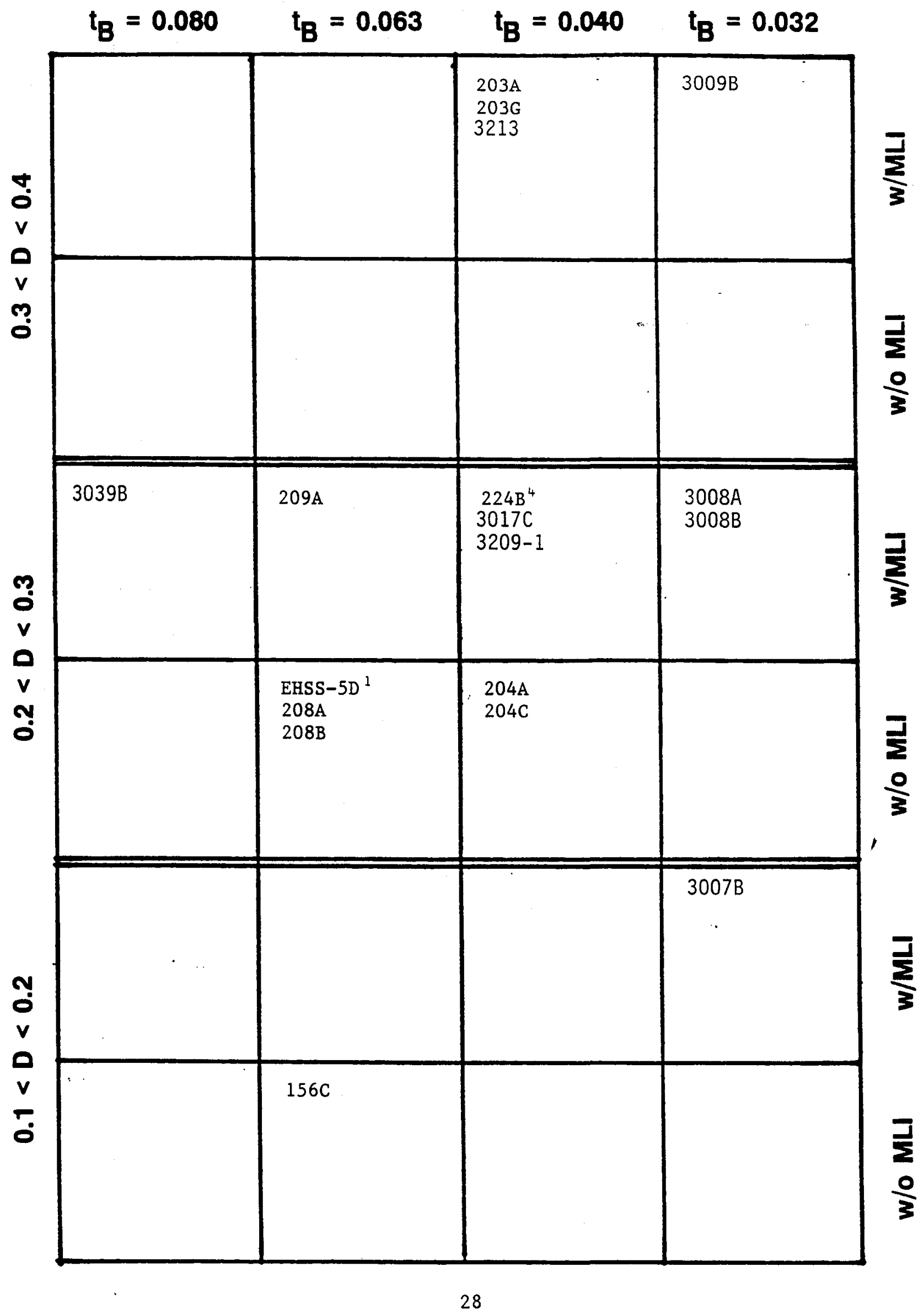




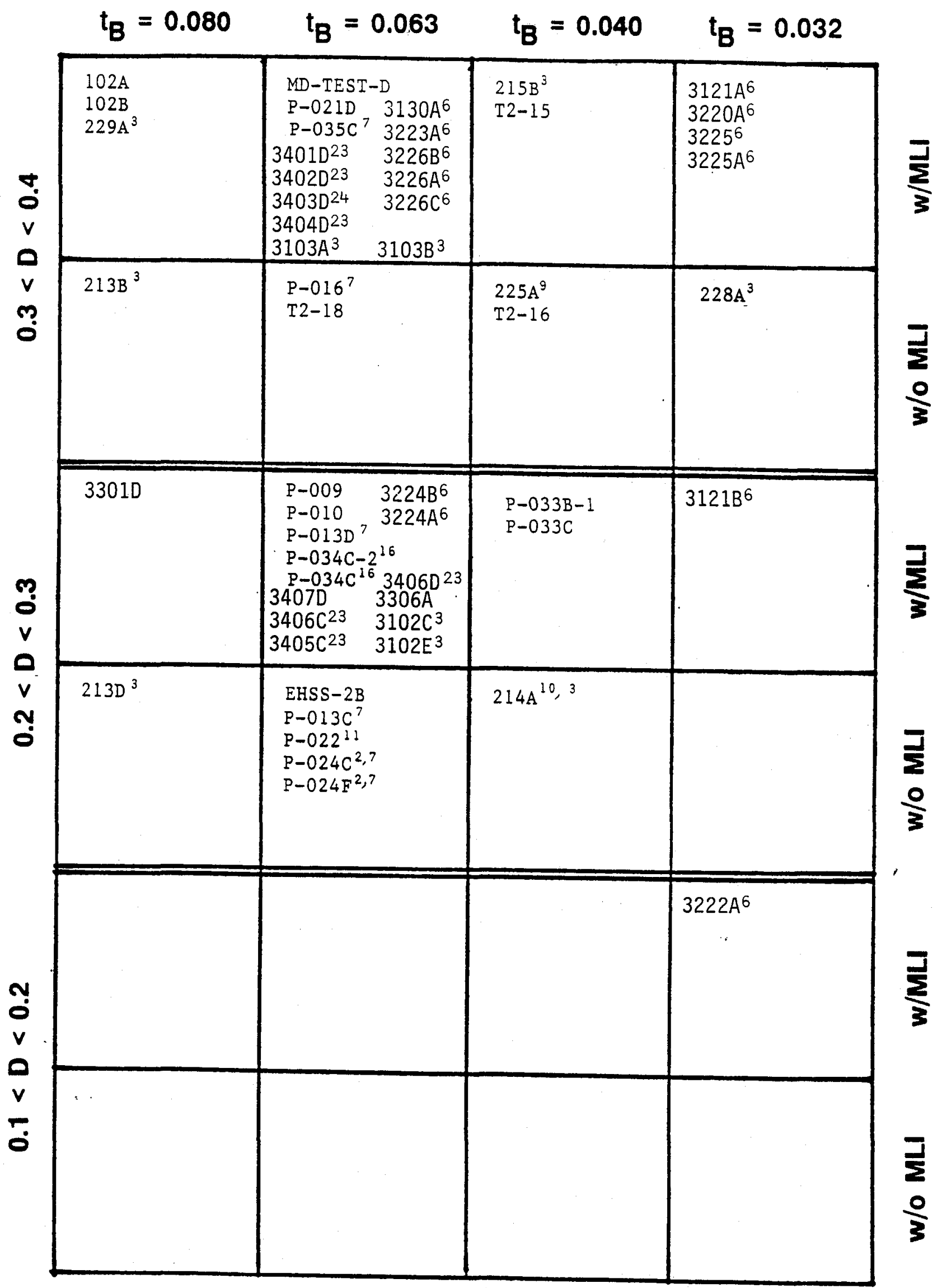




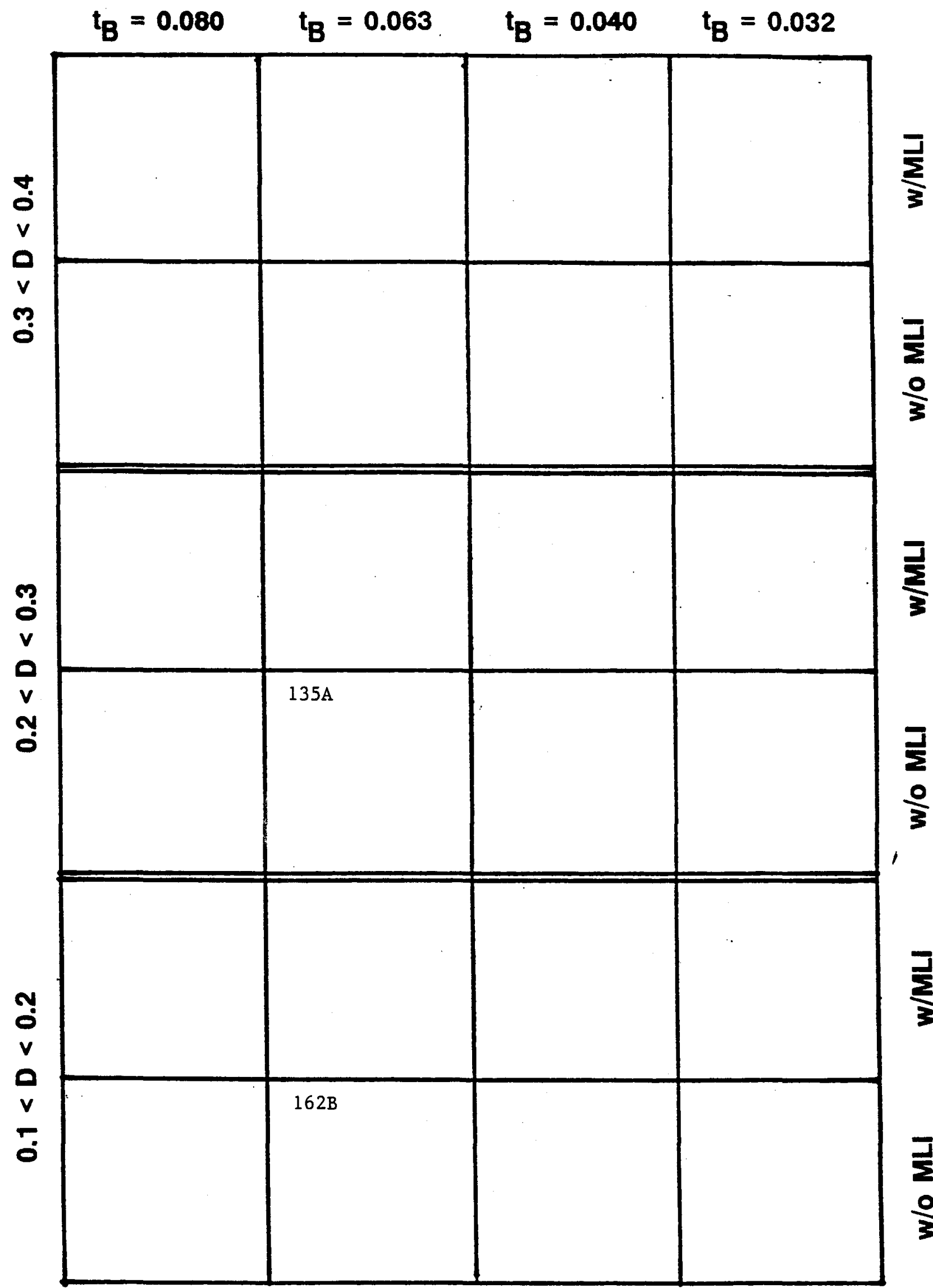




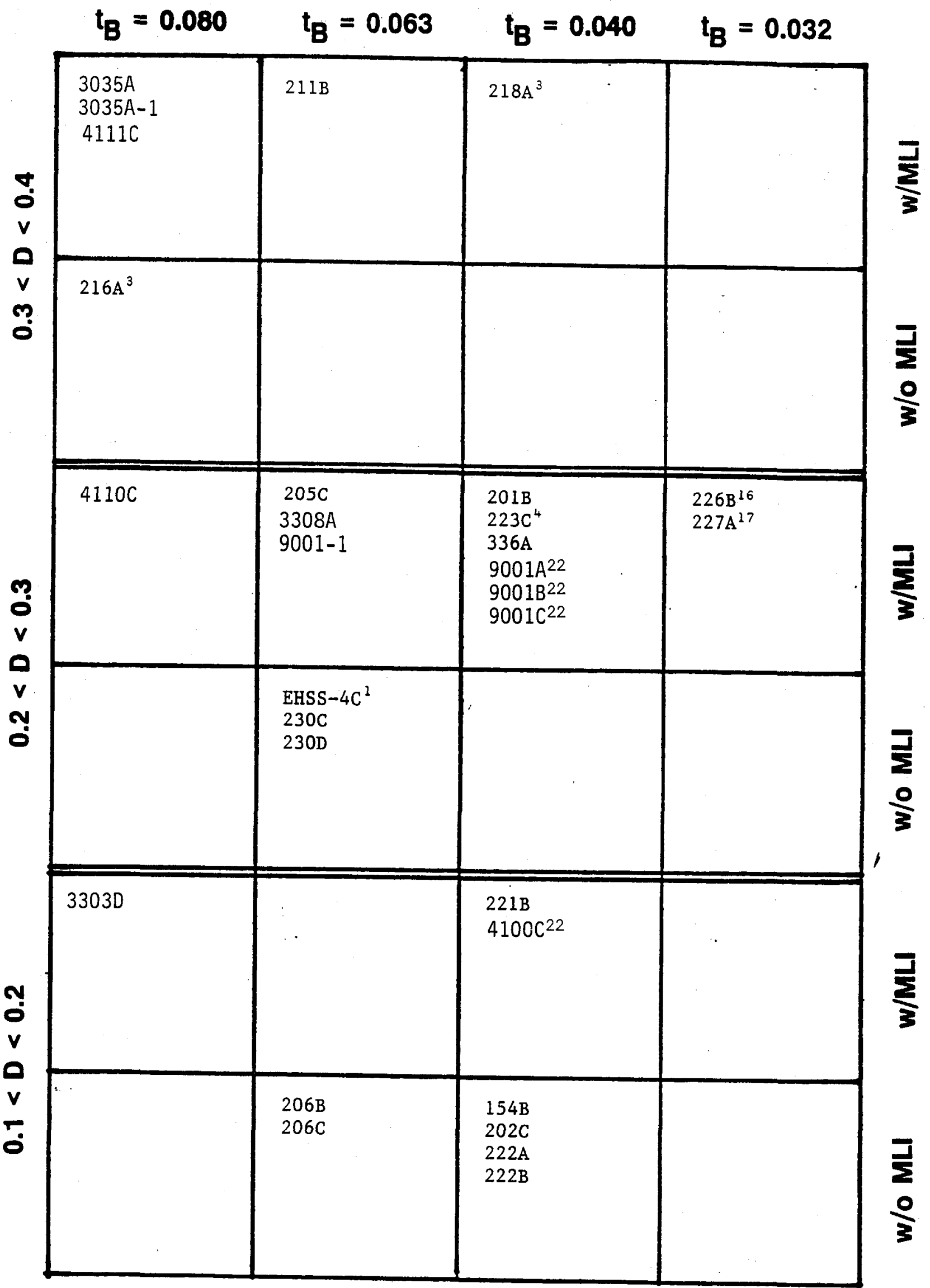




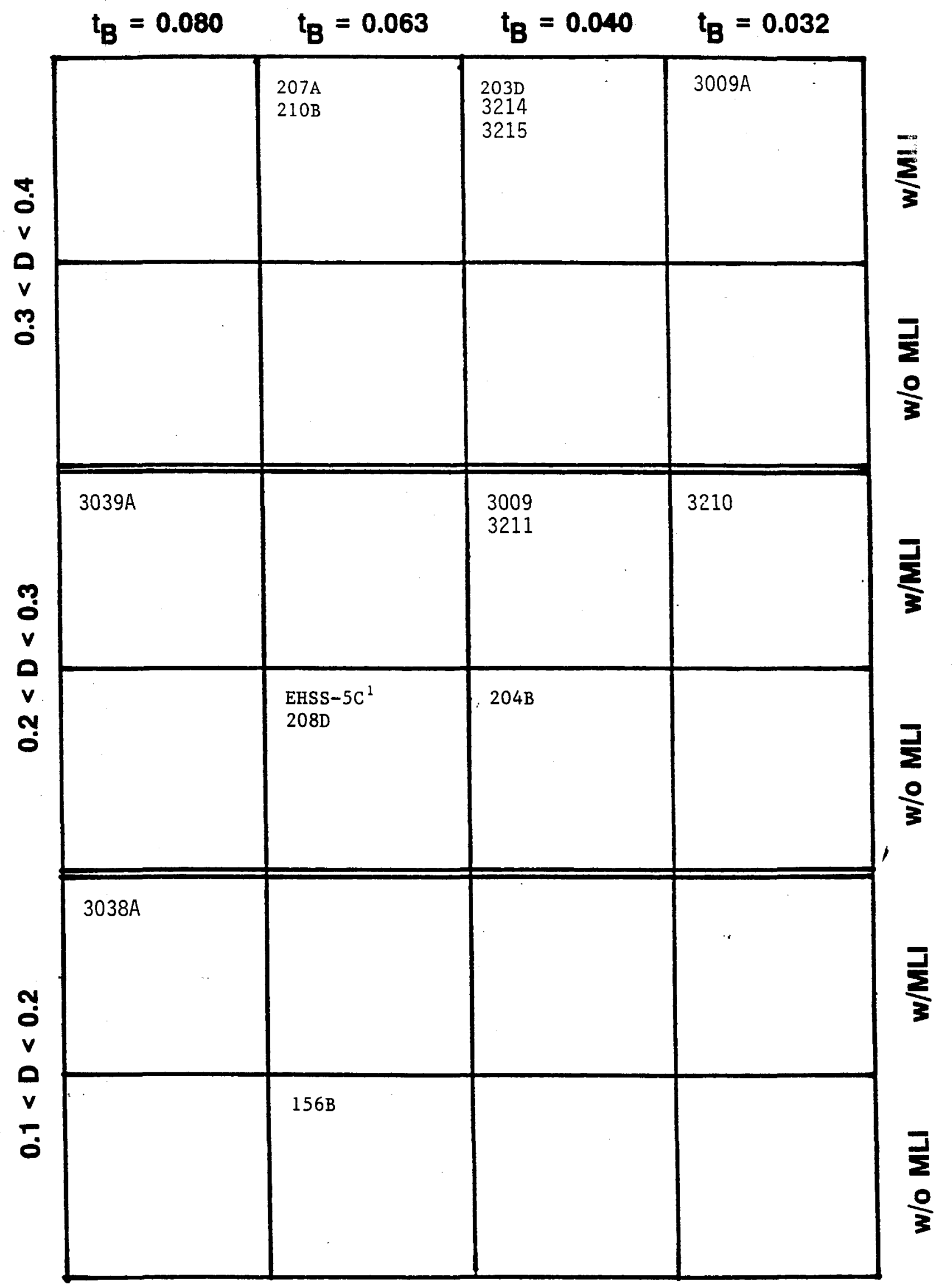




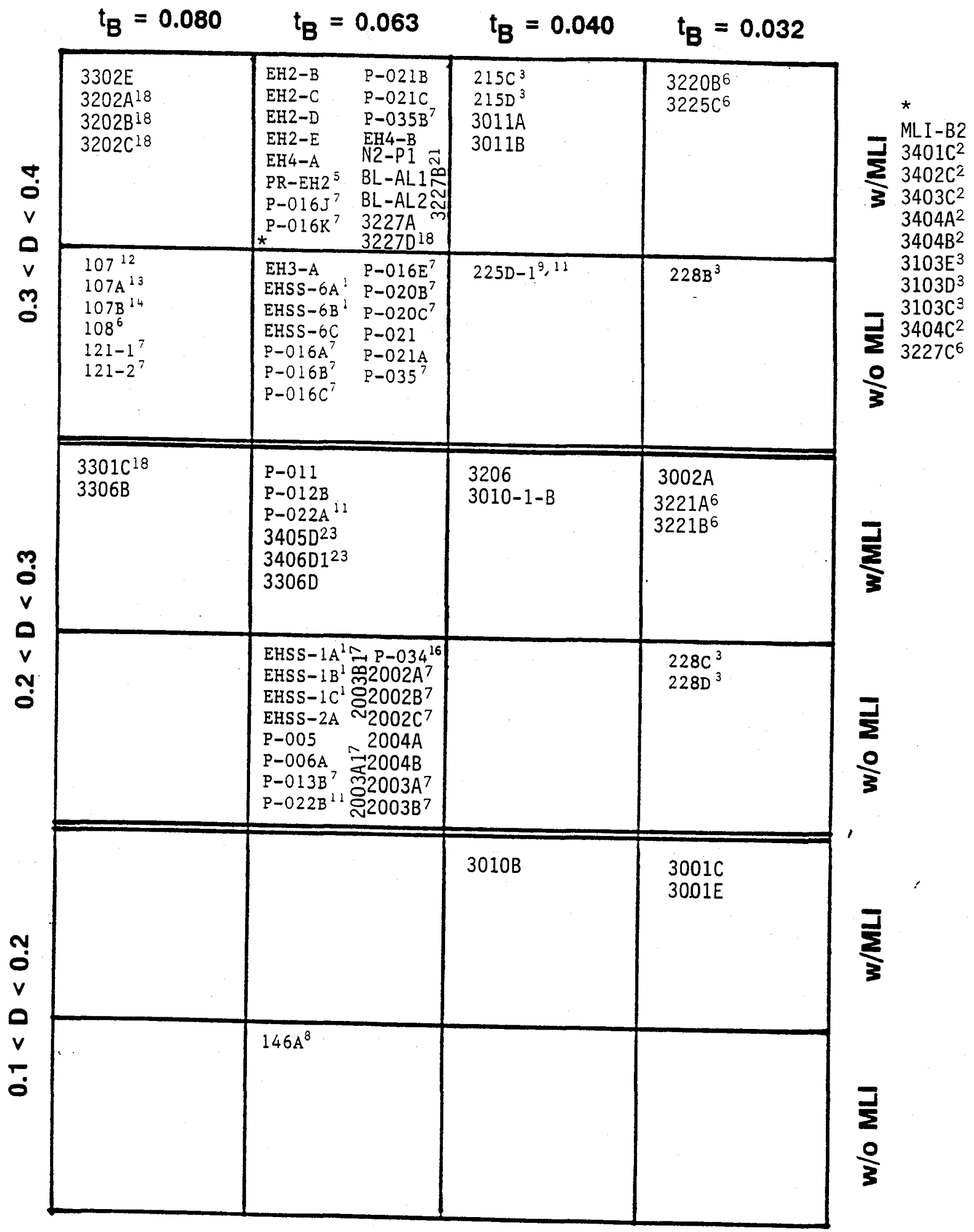




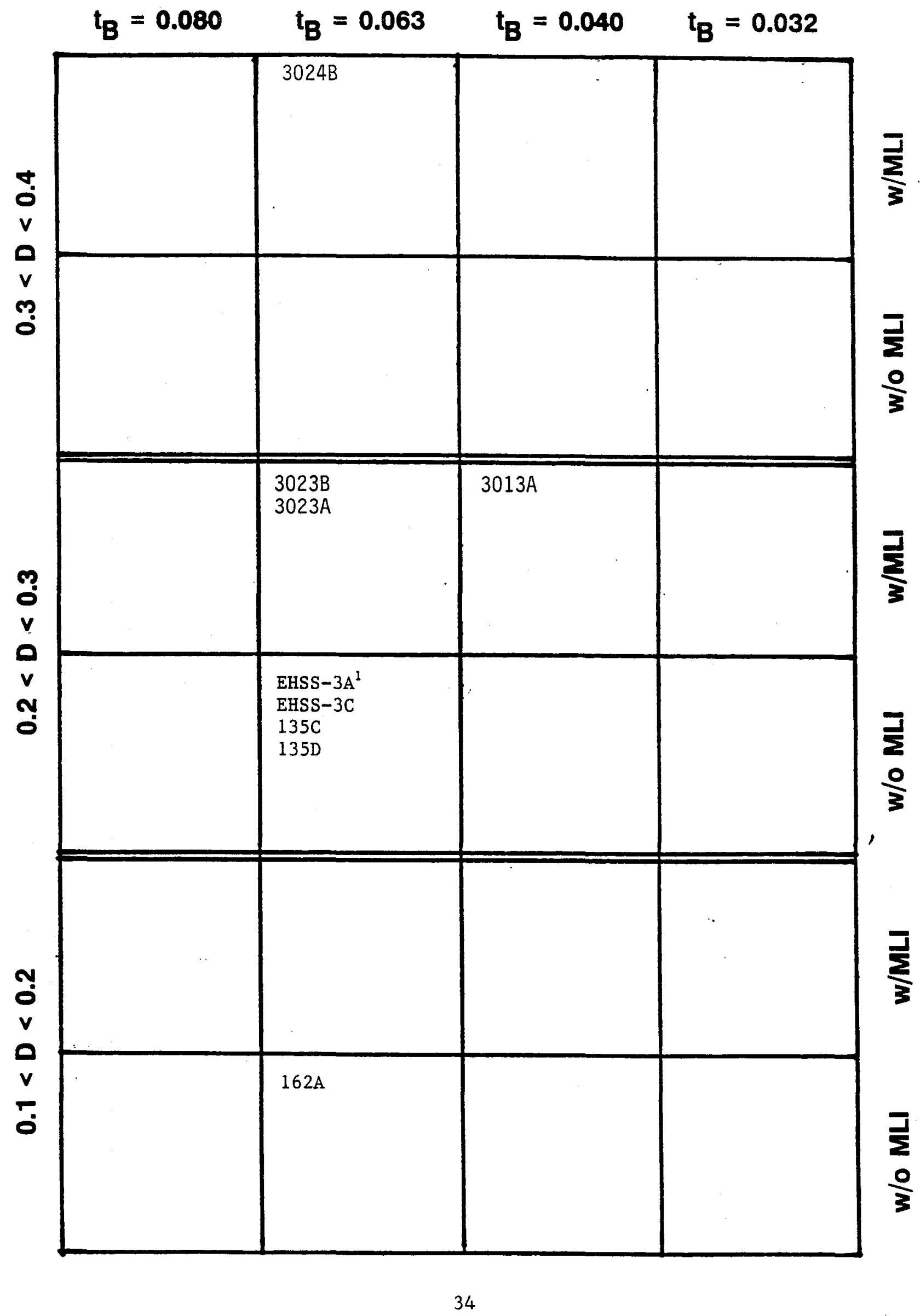




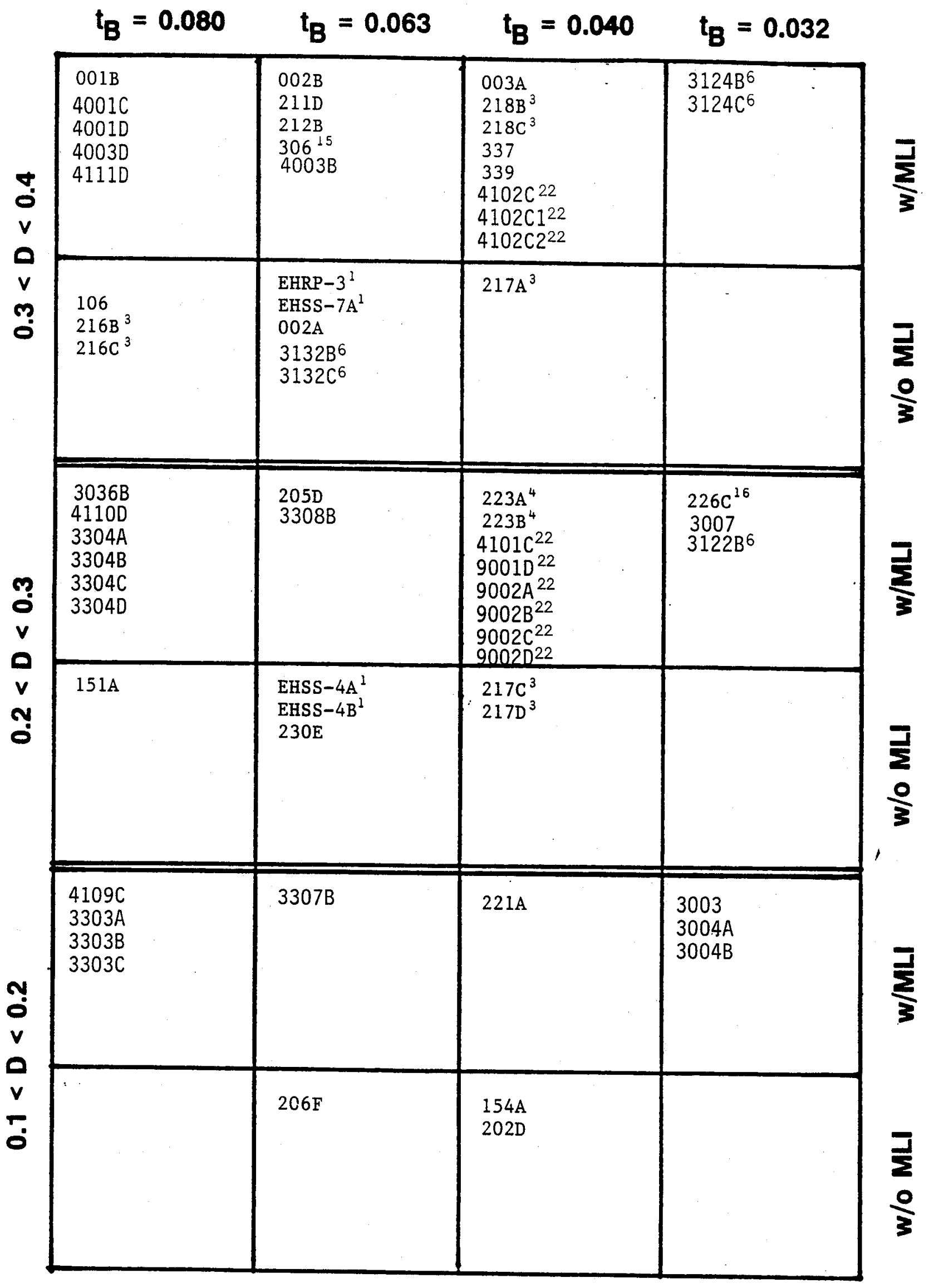




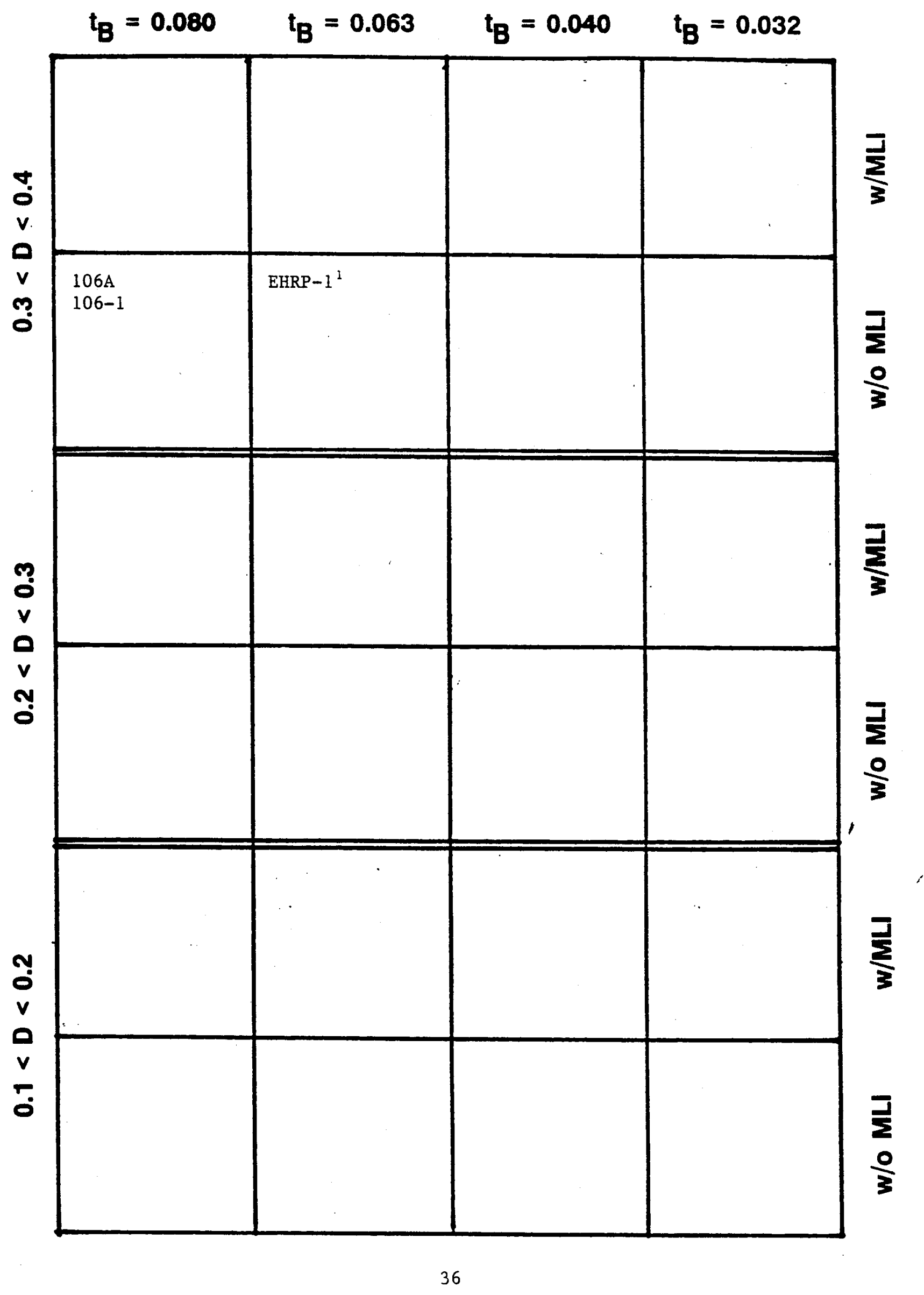




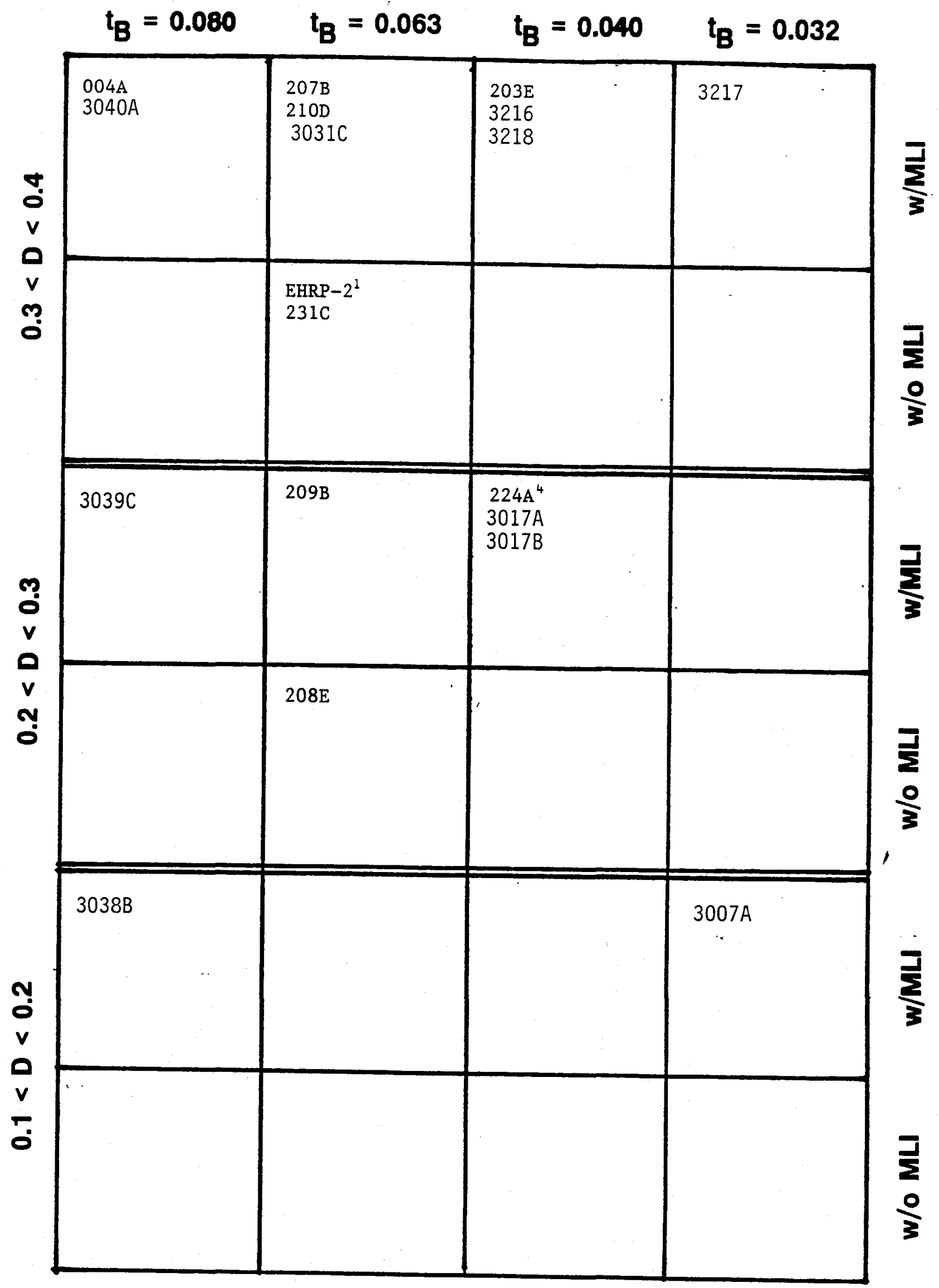




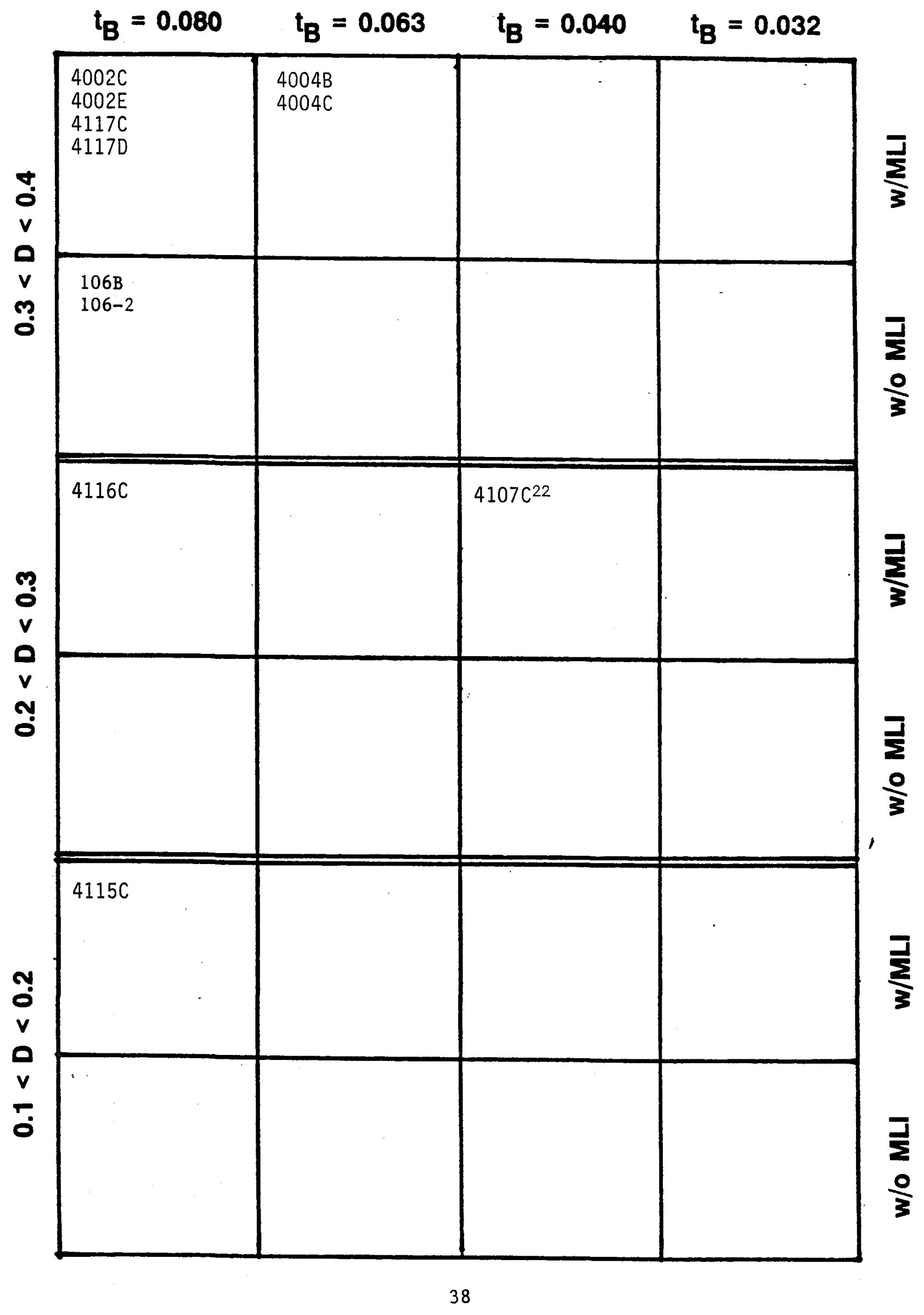




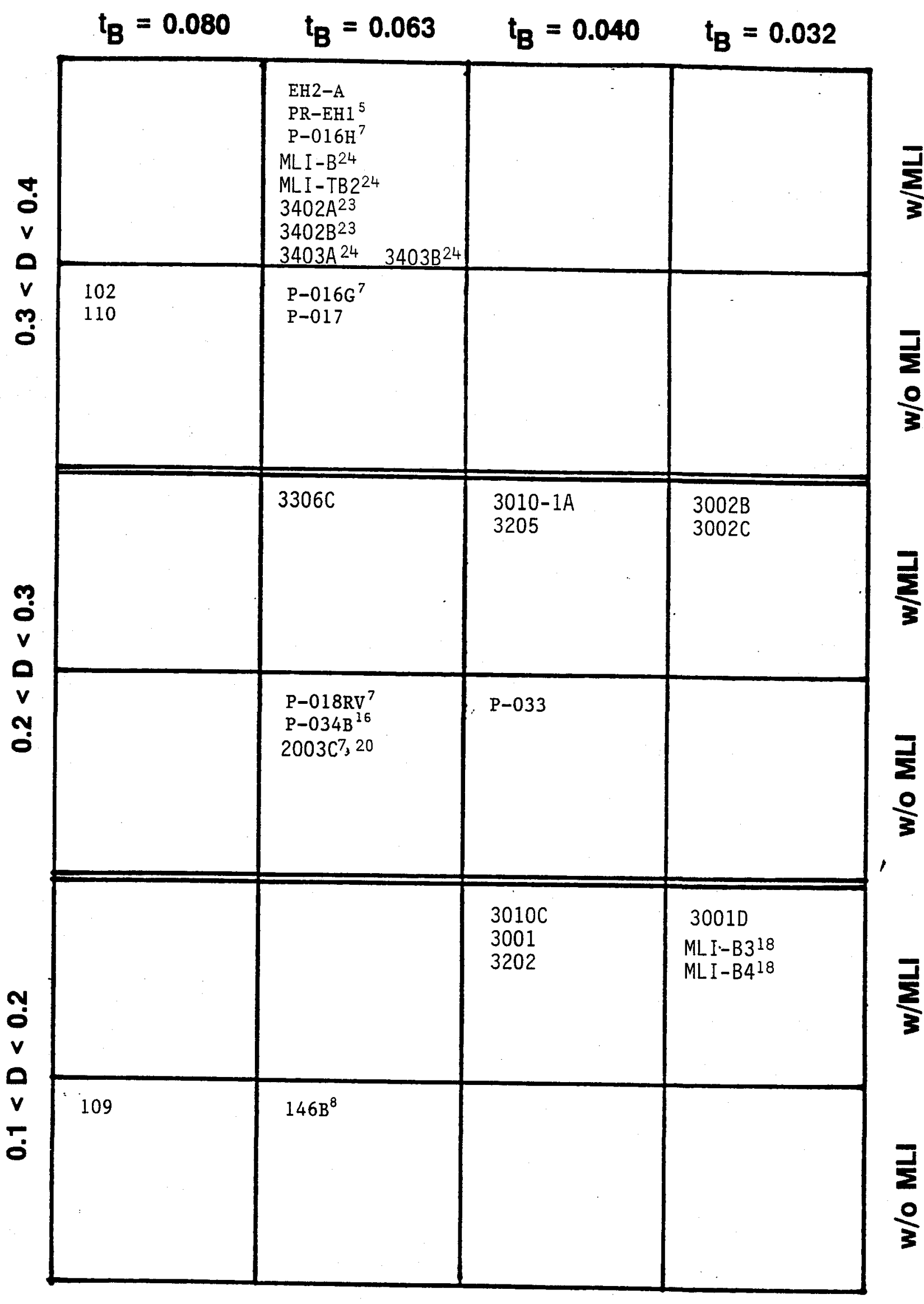




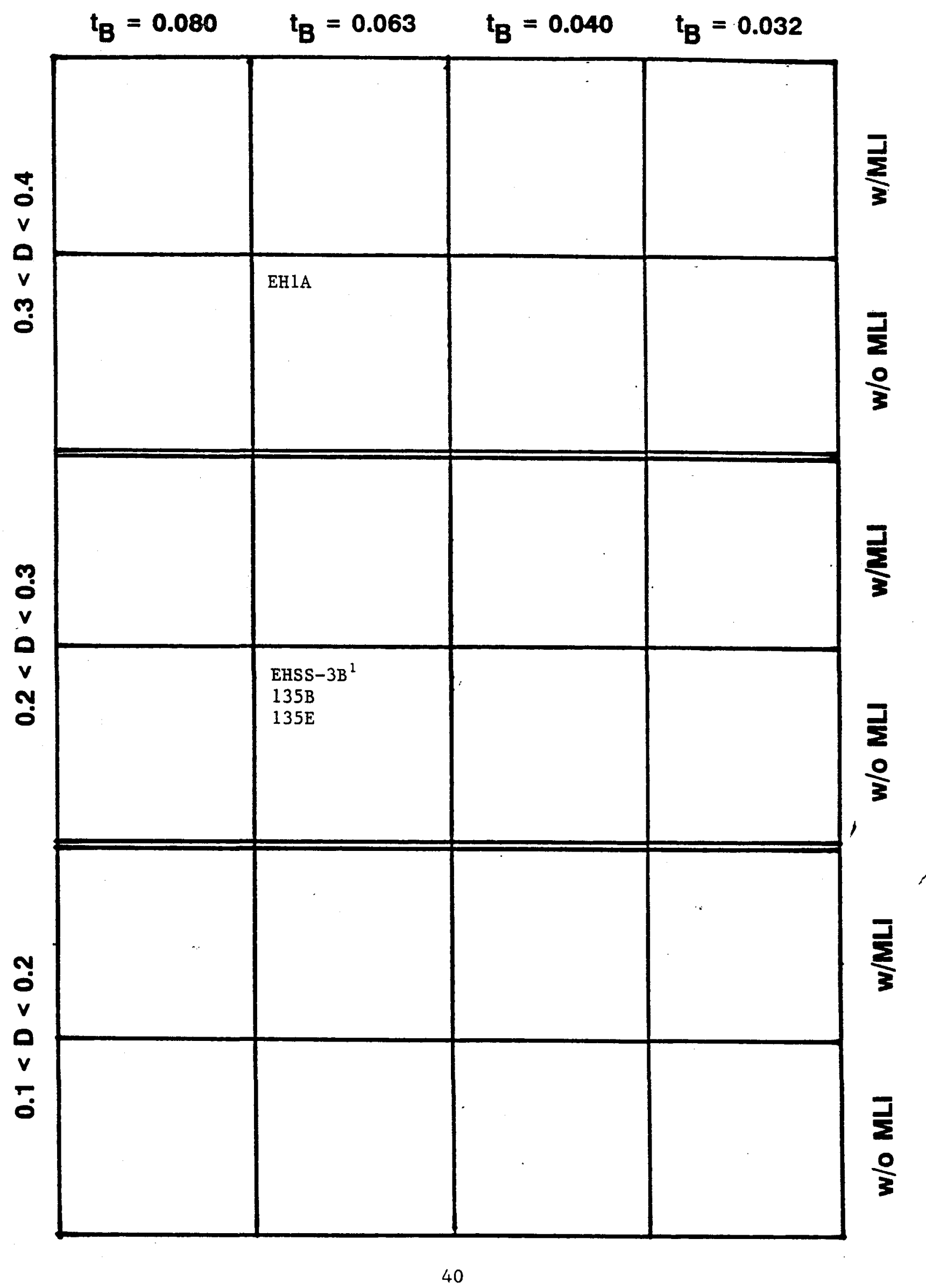




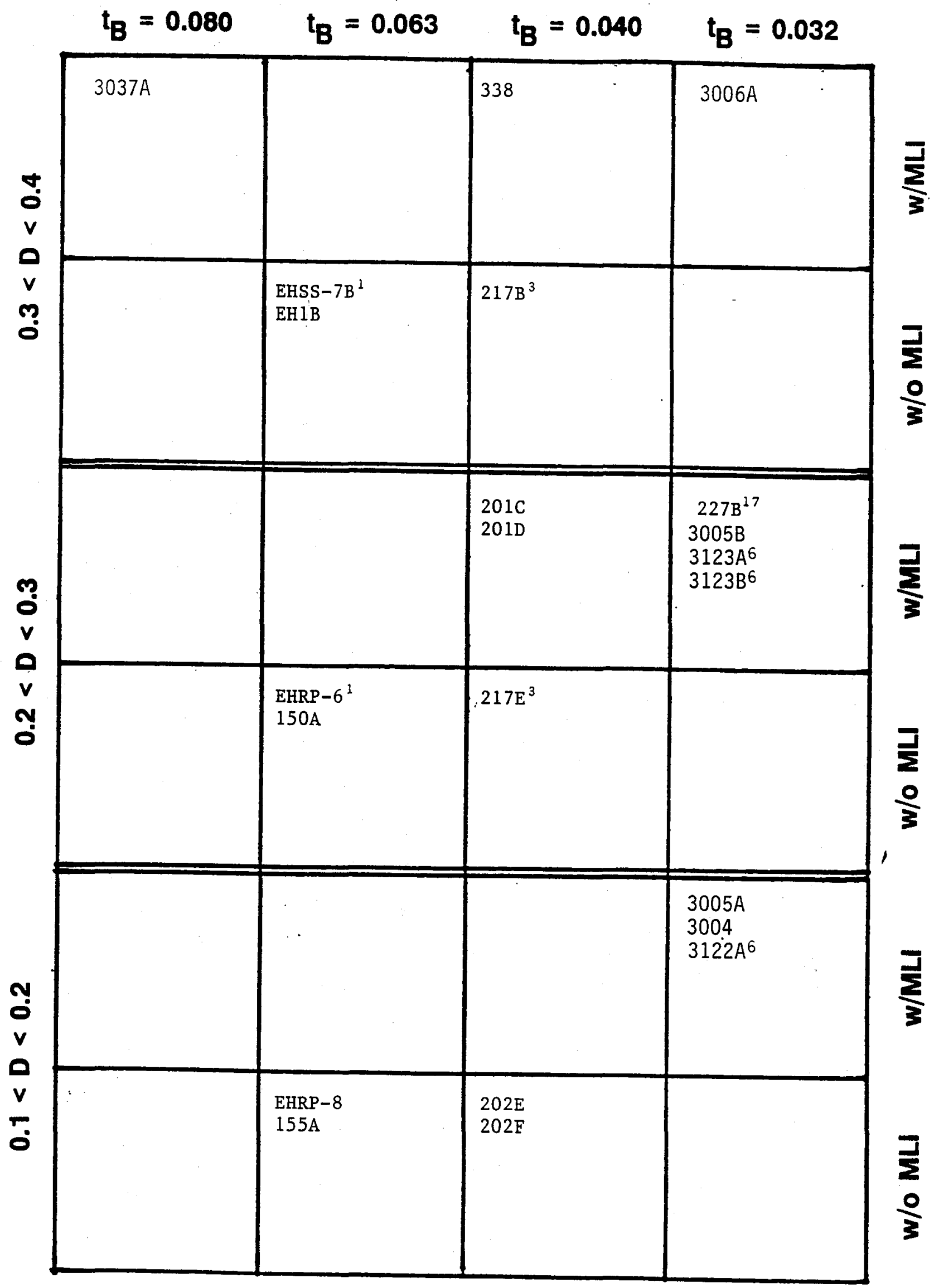




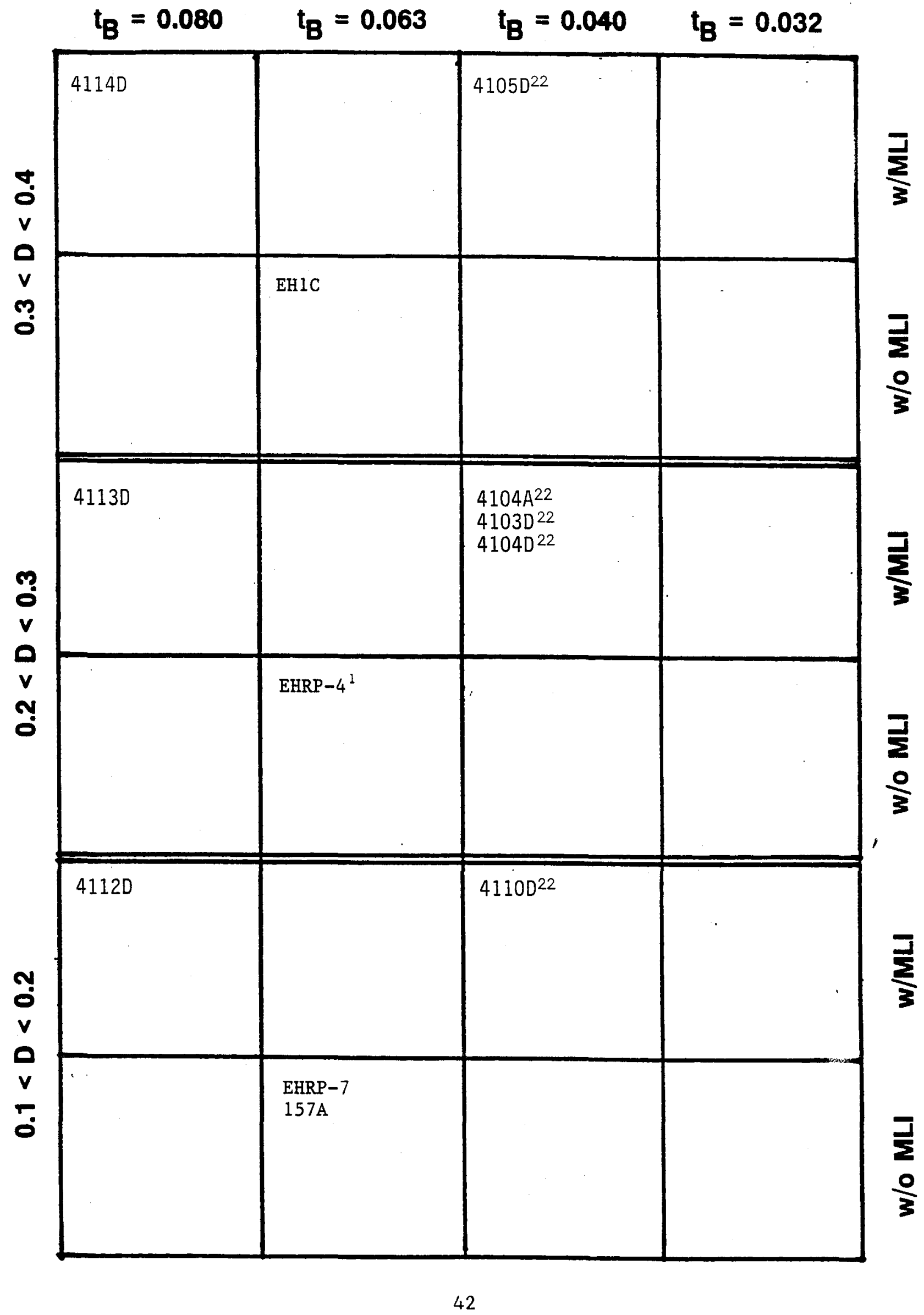




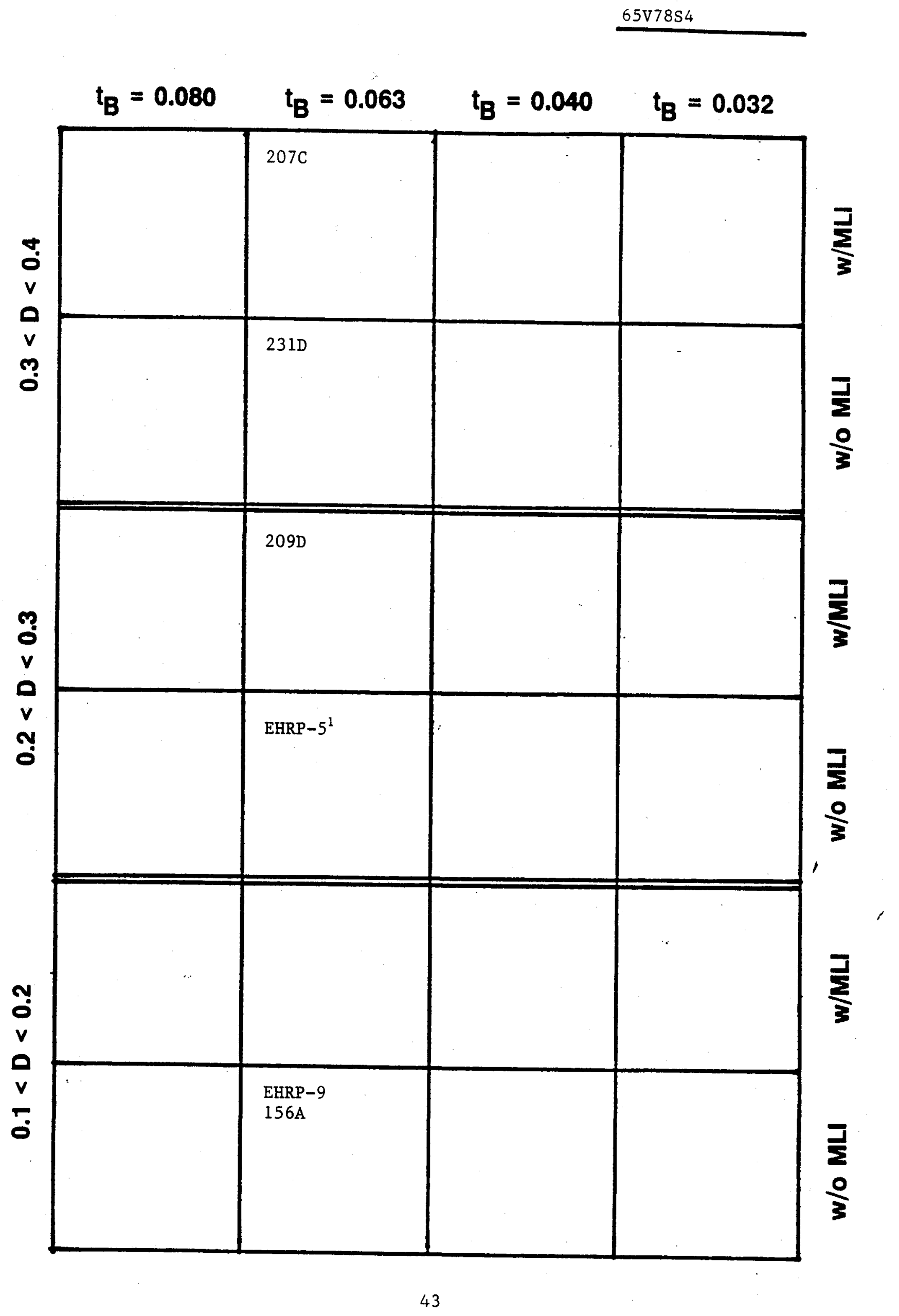




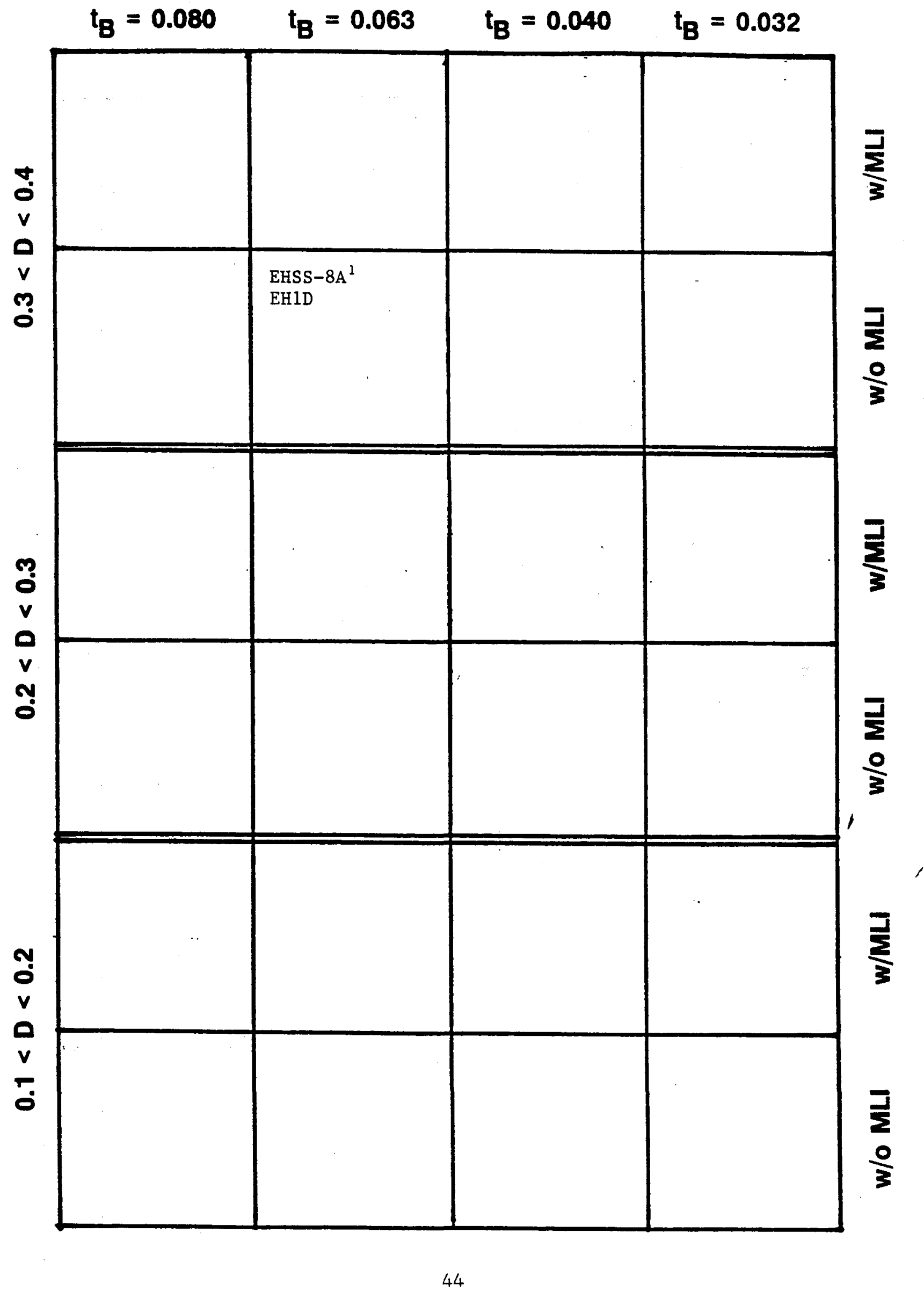




\subsection{REPEATABILITY AND UNCERTAINTY ANALYSES}

\subsection{Introductory Comments}

This section presents the results of the experimental phenomena repeatability and data uncertainty analyses performed using the NASA/MSFC Phase B and Phase C/D hypervelocity impact test data. Following a summary of the principles involved in uncertainty analysis, the methodologies used in the analyses is described. The principles discussed are a synopsis of those presented in Ref. [3.1] and can be explored in greater detail by consulting that text. The results of the analysis are then presented and discussed. Recommendations are offered for future test programs that would enhance and expand the results presented herein.

\subsection{Concepts in Uncertainty Analysis}

In any experimental procedure, a question exists as to whether or not the procedure will yield the same results if the experiment were to be repeated under identical conditions. In almost all cases, the answer is negative. A simple explanation for this is that there is no such thing as a perfect experiment with a perfect measuring device. All measurements are bound to contain errors that may vary from trial run to trial run, even under the same experimental conditions. The nature of these errors must be well understood if experimental results are to be used in subsequent calculations, comparisons, or design exercises.

Measurement error, i.e. the difference between a measured value and the true value of a measureable quantity, can be said to consist of two parts. One part, called 'bias error', refers to a fixed component of the total error that is present in all measurements of a specified quantity. Another part, the 'precision error', refers to the random component of the total 
error that varies from one measurement to the next, even of the same quantity by the same individual.

Unfortunately, we never know the true value of any quantity we measure. Therefore, it is impossible to explicitly state what the error is in the measurement of an experimental quantity. However, it is still possible to make a statement about our perception of the true value of a quantity based on our measurements of it. This statement typically consists of specifying how confident we are (usually in the form of a percentage) that the true value lies within an interval about the mean value of our measurements of a specific quantity. The extent of that interval about that mean value is called the uncertainty in the quantity for our specified confidence value. For example, we can say that we are $95 \%$ sure that the actual elastic modulus of a material is $100 \mathrm{GPa} \pm 20 \mathrm{GPa}$, but only $75 \%$ confident that it is $100 \mathrm{GPa}$ $\pm 5 \mathrm{GPa}$. As illustrated in this example, our confidence that the true value of a quantity lies within a certain interval decreases as the interval decreases.

The analysis of uncertainties in experimental measurements provides the user of experimental data with an estimate of experimental error. It also provides a measure of how 'good' the experimental results really are. Traditional uncertainty analysis requires that a relatively large number of experimental runs be performed under the same conditions in order to have a fairly large level of confidence that the results obtained are either representative of the true value or are all off by a fixed amount. However, if an experiment is performed only once or just a few times, it is very difficult to assess the level of uncertainty in the experimental results. 


\subsection{Methodology}

\subsubsection{Overview and Objectives}

The objectives of the analyses performed were two-fold: first, to quantify the repeatability of the phenomena ocurring in dual-wall structures under hypervelocity impact based on the testing performed at the NASA/MSFC light gas gun during the time period 1985-1991; and second, to determine the uncertainty of the measurements taken from damaged test-specimens. These objectives were achieved through the following two stage analysis procedure.

The first stage of the analysis was concerned with simply whether or not identical dual-wall structures would be perforated or exhibit rear-side spallation under the same impact conditions. This issue was concerned only with consistency in overall response - - perforation vs. no perforation or spall vs. no spall - under the same impact conditions. Since no measureable quantity was involved in this stage of the analysis, standard uncertainty analysis procedures were not used; only an approximate quantifiable measure of the overall repeatability of the phenomena ocurring in dual-wall structures under hypervelocity impact based on testing at the NASA/MSFC light gas gun facility was obtained.

The second stage of the analysis focussed on the uncertainty of the measurements of detailed response characteristics for identical structures under the same impact conditions. Response characteristics such as pressure wall equivalent single hole diameter, pressure wall damage area and rearside spall area were analyzed to determine level of uncertainty in the data produced by the test facility as well as the consistency of the damage levels found in dual-wall structures under hypervelocity impact. 
A review of the Phase $B$ and Phase $C / D$ impact test parameter databases revealed an unfortunate circumstance: wery few of the impactests were repeated under the same impact conditions. Thus, a traditional repeatability analysis of the phenomena involved in the response of dual-wall structures to hypervelocity projectile impact and a traditional uncertainty analysis of the measured test data were impossible to perform. However, rather than abandon the entire exercise, modified repeatability and uncertainty analyses were performed by pooling together several related groups of tests. This resulted in sample sizes of at least 5 to 10 related tests per group. While the pooled test groups were by no means large, at least some sort of comparison and assessment of phenomena repeatability and test data uncertainty became possible. For example, one such grouping was all tests on dual-wall structures without MLI and with $t_{s}=1.6 \mathrm{~mm}, t_{w}=3.175 \mathrm{~mm}$, and $\mathrm{S}=10.16 \mathrm{~cm}$. Within that group, tests were then paired according to similarity in projectile diameter, trajectory obliquity and impact velocity.

All test groups possible using the Phase $B$ and Phase C/D data are shown in Tables 3.10-3.13 in Section 3.8. In Tables 3.10-3.13, the position of the MLI in a particular test is denoted by one of the abbreviations $R B, B B$, HW, or PWP. The abbreviations correspond to on the rear of the bumper plate, 0.25 inches in back of the bumper plate, half-way between the bumper and pressure wall plates, and one the pressure wall plate, respectively. In these tables, it can be seen that the velocities of 'identical' tests are not equal. With a complex test apparatus such as a light gas gun, it is virtually impossible to duplicate impact velocity. At best, one can expect velocities to be within 0.1 or $0.2 \mathrm{~km} / \mathrm{sec}$ of each other. Thus, in the 
pairing of the tests in each group, tests with impact velocities within 0.2 $\mathrm{km} / \mathrm{sec}$ of each other were considered to be similar enough so that their results could be compared against each other. This presumption is justified by the following argument.

The response of the dual-wall structure is governed by the extent to which the projectile and the impacted outer wall fragment, melt, and/or vaporize. The extent of fragmentation, melting, and/or vaporization is in turn governed by the shock pressures generated by the initial impact. A simple one-dimensional shock physics analysis using the shock jump conditions and a linear relationship between shock velocity and particle velocity shows that shock pressures are found by the addition of two terms. The first term is linearly related to particle velocity while the second is a function of particle velocity squared. Since the particle velocity is directly related to the impact velocity, it follows that shock pressures are a function of linear and quadratic terms in impact velocity.

In light of this reasoning, the effect of a difference of $0.2 \mathrm{~km} / \mathrm{sec}$ in impact velocity would only be significant in the linear term; its effect would be negligible in the quadratic term. For an impact velocity of of 3 $\mathrm{km} / \mathrm{sec}$, a change of $0.2 \mathrm{~km} / \mathrm{sec}$ would represent a change of approximately $6.7 \%$ in shock pressure, while at $7 \mathrm{~km} / \mathrm{sec}$ the change in shock pressure would be only $2.9 \%$. In either case, if these low changes in shock pressures do not result in a change in the physical nature of the response (i.e. so long as both velocities are below the velocity required to fragment the projectile and bumper plate, or so long as both are below the incipient melt velocity, etc.), then the effects of a $0.2 \mathrm{~km} / \mathrm{sec}$ difference in impact velocity can be ignored. 


\subsubsection{Phenomena Repeatability Methodology}

In the first stage of the repeatability analysis, a quantifiable level of repeatability for dual-wall systems tested in the NASA/MSFC light gas gun was determined by calculating how mainy test pairs within a group of tests sustained pressure wall perforation or rear-side spall in both tests of each pair and how many did not. The repeatability for that group of tests was then stated as the percentage of test pairs that were in agreement with regard to pressure wall perforation or rear-side spallation. This quantity will be referred to as the 'Repeatability Index' for the specific group of tests under consideration. The results of the analyses performed in this stage are summarized for the various test groupings in Tables 3.1-3.5.

In the test groups presented in these Tables, the position of the MLI within the dual-wall system is accounted for only in the pairing of the tests used in direct comparisons (see Section 3.8). In presenting a summary of the results in Tables 3.1 through 3.5 , no distinction is made between the various MLI positions noted in the tables in Section 3.8. Also, whereas Table 3.1 presents Repeatability Indices for stand-off distances of 10.16 , 15.24, and $30.48 \mathrm{~cm}$, the results presented in Tables 3.2 through 3.5 are only for tests with a 10.16 stand-off distance. The small number of tests at the other larger stand-off distances precluded any further more detailed analyses being performed. Finally, entries of ' $N / A^{\prime}$ in Tables $3.4 \mathrm{a}$ and 3.5 indicate the absence of any test pairs with the particular experimental parameter under consideration (i.e. impact velocity and bumper thickness in Tables $3.4 \mathrm{a}$ and 3.5 , respectively). 


\subsubsection{Uncertainty Analysis Methodology}

The second stage of the analysis consisted of a more traditional uncertainty analysis of the experimental data obtained from the high speed impact tests. These methods were somewhat modified to account for the paucity of tests under identical test conditions. In addition, two different but related approaches were used in performing the uncertainty analyses. Because of the scarcity of tests with the same impact parameters, it was not possible to determine the uncertainty in actual test results for bumper plate hole diameter, for example, or for pressure wall damage area. However, by pooling together the results of several related tests, it became possible to determine the uncertainty in the ratios of, for example, pressure wall damage area for all the pairs of tests within a specific group.

The first approach was based on the presumption that the lack of sufficient information precluded making any specific comments regarding the 'true' value of any parameter based on the experimental data available. However, in this case, it was still possible to calculate for a given confidence level ' $c$ ' and for the parameters of the test group under consideration, the interval within which ' $c \%$ ' of the response parameter ratios would be expected to fall if more tests were performed under similar impact conditions. These results can also be used to state that there would be a 'c\%' probability that a test ratio pair would lie in the calculated response parameter ratio interval.

. The second approach differed from the first in that it was used to calculate, for a given confidence level ' $c$ ' and for the parameters of the test group under consideration, the interval within which it can be supposed lay the 'true' value of a damage response parameter for a given set of 
impact parameters relative to test data obtained at those same parameters. In both approaches, the calculations performed assumed that there were no bias errors present in the data. These two approaches are discussed in more detail in Sections 3.3 .3 .1 and 3.3.3.2, respectively.

Since the analysis in this stage of the effort required comparisons between response characteristics that were sensitive to impact velocity, it was originally thought that the quantities being considered should be adjusted to reflect any difference in velocity between two tests. However, the only way this could have been done was by using an empirical predictor equation for the response characteristic under consideration to determine some sort of 'adjustment factor' for the results of one of the tests. Since the predictions of such equations themselves have some inherent error, such adjustments would be counter-productive and would confuse rather than clarify the issue. Thus, actual test results were used in the second phase of the repeatability study even though the impact velocities for a test pair may have differed by $0.2 \mathrm{~km} / \mathrm{sec}$.

\subsubsection{Uncertainty Analysis -. First Approach}

Mathematically, a 'c\%' response parameter ratio interval can be defined as follows:

$$
\mu_{\rho}-\eta_{c} \sigma_{\rho}<\rho<\mu_{\rho}+\eta_{c} \sigma_{\rho}
$$

where $\mu_{\rho}$ and $\sigma_{\rho}$ are the mean and standard deviations of the ratios $\rho$ for a particular quantity (i.e. hole diameter, damage area, etc.) for the test pairs within a specific test group. The quantity $\eta_{c}$ is a numerical multiplier that is obtained from statistical tables (see, e.g. [3.1,3.2]) and is 
a function of the number of ratios considered in calculating $\mu_{\rho}$ and $\sigma_{\rho}$ and the level of confidence ' $c$ ' specified.

At this point it should be noted that there are two basic ways of calculating the ratios described above. The first is to force all the ratios within a test group to be less than unity by dividing the smaller of the two quantities in the test pairs by the larger; the second is to force all the ratios within a test group to be greater than unity by doing the exact opposite. If all the ratios are less than one, the following modified version of equation (1) provides the interval of interest for a specified confidence level:

$$
\mu_{\rho<1}-\eta_{c} \sigma \rho<1<\rho<\mu_{\rho<1}+\eta_{c} \sigma_{\rho<1}
$$

where $\mu_{\rho<1}$ and $\sigma_{\rho<1}$ are the mean and standard deviation of the ratios for a particular response quantity, respectively, when all the ratios are less than one. If all the ratios are greater than one, the following equation will provide the required interval:

$$
\mu_{\rho>1}-\eta_{c} \sigma \rho>1<\rho<\mu_{\rho>1}+\eta_{c} \sigma \rho>1
$$

where $\mu_{\rho>1}$ and $\sigma_{\rho>1}$ are the mean and standard deviation of the ratios for a particular response quantity, respectively, when all the ratios are greater than one.

Since there is no reason to suppose that the next response parameter ratio will be less than or greater one, it may be argued that the appropriate interval to be calculated for a given confidence level is one whose lower limit given by equation (2a) and whose upper limit given by equation (2b), that is, 


$$
\mu_{\rho<1}-\eta_{c}^{\sigma}{ }_{\rho<1}<\rho_{0}<\mu_{\rho>1}+\eta_{c}^{\sigma} \rho>1
$$

where $\rho_{0}$ represents the ratio of two response parameter values without any specification that the ratio be less than or greater than one. It is this modified c\% confidence interval that will be used to specify the rarge within which 'c\%' of the response parameter ratios would be expected to fall if a large number of tests were to be performed under similar test conditions.

The analyses described in the previous paragraphs require the assumption of a certain confidence level ' $c$ ' to determine a modified ' $c \%$ ' confidence interval. The specified value of ' $c$ ' and the number of degrees-offreedom ' $n$ ' in a particular test group (which equals one less than the number of tests ' $N$ ' within a specific group) is the information required to obtain the appropriate value of $\eta_{c}$ to be used in equation (3). Valies of $\eta_{c}$ for certain values of ' $\mathrm{c}$ ' and $\mathrm{n}=\mathrm{N}-1$ are given in Table 3.6; Tables 3.7-3.9 contain means and standard deviations for the various test groupings considered in this portion of the study.

\subsubsection{Uncertainty Analysis -. Second Approach}

The equations required for the second approach are obtained using the same principles as those which were used in the derivation of the equations for the first approach. Specifically, to obtain a c\% confidence interval for a test value-to-true value ratio that is less than one, equation (2a) is re-written as

$$
\mu_{\rho<1}-\eta_{c}^{\sigma} \sigma_{\rho<1}<\mathrm{x}_{\text {test }} / \mathrm{x}_{\text {true }}<\mu_{\rho<1}+\eta_{c}^{\sigma} \sigma_{\rho<1}
$$

where $\mathrm{X}_{\text {test }}$ is a test value for a response parameter under specific test 
conditions, $x_{\text {true }}$ is the 'true' value of that parameter under the same test conditions, and the quantities $\eta_{c}, \mu_{\rho<1}$ and $\sigma_{\rho<1}$ are as defined in Section 3.3.3.1. Similarly, equation (2b) then becomes

$$
\mu_{\rho>1}-\eta_{c} \sigma \rho 1<x_{\text {true }} / \mathrm{x}_{\text {test }}<\mu_{\rho>1}+\eta_{c} \sigma_{\rho>1}
$$

As before, since we do not know if the 'true' value of a response parameter under consideration is less than or greater than an existing (or a future) test value, equations (4a) and (4b) are combined to yield

$$
\mu_{\rho<1}-\eta_{c}^{\sigma}{ }_{\rho<1}<\rho_{0}<\mu_{\rho>1}+\eta_{c} \sigma \rho>1
$$

where again $\rho_{0}$ represents the ratio of the true value to a test value without any specification that the ratio be less than or greater than one. Values for $\eta_{c}$ are again found using Table 3.6 and as before, Tables 3.7 through 3.9 are used to obtain means and standard deviations for the various test groupings considered.

\subsection{Results and Discussion - Repeatability Analysis}

\section{4 .1 Introductory Comments}

The results of the phenomena repeatability analysis (i.e. phase one of the total effort) presented in Tables 3.1 through 3.5 show that if 3 identical dual-wall structures with $t_{w}=3.175 \mathrm{~mm}$ and $S=10.16 \mathrm{~cm}$ were tested using the NASA/MSFC light gas gun under similar impact conditions (i.e. identical projectile diameter and trajectory obliquity, impact velocity within 0.2 $\mathrm{km} / \mathrm{sec}$ ), then it is entirely likely that either the pressure walls in 2 of these 3 tests will be perforated and 1 will not or the pressure walls in 2 of these tests will not be perforated and 1 will. These Tables also show that the repeatability of rear-side spallation (or the lack thereof) in such 
dual-wall structures is considerably higher: of 10 tests performed, it is highly likely that 9 of them will all either show some sort of rear-side spallation and 1 will not or 9 of them will all either not be spalled and 1 of them will. A more detailed review of Tables 3.2 through 3.5 reveals the following trends in perforation and spallation repeatability for dual-wall structures based on the Phase $B$ and Phase $C / D$ impact testing performed using the NASA/MSFC light gas gun.

\subsubsection{Repeatability as Function of Stand-Off Distance}

Although the number of tests with a $10.16 \mathrm{~cm}$ stand-off distance was much greater than the number of tests with a stand-off distance larger than $10.16 \mathrm{~cm}$, certain trends are still discernable in the data in Table 3.1 . Most apparent in Table 3.1 is that the perforation and spallation Repeatability Indices for $S=15.24$ and $30.48 \mathrm{~cm}$ are much lower than those for $\mathrm{s}=10.16 \mathrm{~cm}$. This can be explained by the following considerations.

The most significant effect that increasing the stand-off distance has on the response of a dual-wall structure is that it allows the debris cloud created by the initial impact to expand still further before sriking the pressure wall plate. When $\mathrm{S}=10.16 \mathrm{~cm}$, the debris cloud is more compact than when $S=30.48 \mathrm{~cm}$. Any inhomogeneities in the debris cloud (e.g. pockets of air, solid particle concentrations, etc.) are more likely to have a significant effect when the debris cloud is allowed to expand as much as possible. Otherwise, when the debris cloud is relatively compact, debris cloud inhomogeneities are overwhelmed by the overall debris cloud loading. Thus, the response among tests with $S=30.48 \mathrm{~cm}$ will vary more from test to test because debris cloud inhomogeneities, which are a function of material defects and metallurgical imperfections, will vary from test to test. 


\subsubsection{Repeatability as Function of MLI Presence}

Where comparisons between perforation Repeatability Indices for structures with and without MLI were possible (ie. in Table $3.2: \theta=00,30^{\circ}$; in Table 3.3: $D=0.635 \mathrm{~cm}$, and $D=0.795,0.953 \mathrm{~cm}$; in Table $3.4 \mathrm{~b}: 6<V<7 \mathrm{~km} / \mathrm{sec}$; and, in Table 3.5: $t_{s}=1.6 \mathrm{~mm}$ ), the perforation Repeatability Indices for structures without MLI were greater than those for structures with MLI by approximately $23 \%$. This increased perforation repeatability for dual-wall structures without MLI is probably due to the fact adding the MLI introduced another variable into the processes underway as a dual-wall system responds intially to the projectile impact loading and then the loading(s) due to the impact of the debris cloud(s) created by the initial impact. This extra variable in the response would naturally affect the interaction of the various processes, increase the range of possible response characteristics, and therefore decrease repeatability as compared to systems in which it was not present.

\subsubsection{Repeatability as Function of Impact Angle}

As the impact angle was increased from $0^{\circ}$ to $75^{\circ}$, the repeatability indices for dual-wall structures with MLI hovered around $72 \%$ and then decreased to approximately $63 \%$ (Table 3.2 ). When the impact angle is below the critical angle of obliquity [3.3], the majority of debris cloud material is forced into the dual-wall system; only a small amount is expelled rearward as backsplash or ricochet debris. However, then the impact angle exceeds the critical angle, the majority of the debris cloud material is expelled as ricochet debris. For aluminum projectile impacting thin aluminum plates, this angle has been shown to have a value of approximately $60-65^{\circ}[3.3]$. 
Thus tests performed near the critical angle (i.e. at $60^{\circ}$ and $65^{\circ}$ ) may show a wide variation in response characteristics as the response of the dualwall system transitions from one mode of response (inward travelling debris clouds) to another (outward travelling or ricochet debris clouds).

While the Repeatability Index for dual-wall structures without MLI was relatively high for near-normal impacts (nearly $80 \%$ ), sufficient information was not available at other trajectory obliquities to be able to quantify repeatability. With regard to spallation repeatability, for dual-wall structures with MLI, the Repeatability Indices increased as the impact angle increased. As noted previously, the presence of MLI effectively eliminates the possbility of rear-side spallation [3.3]. Hence, the agreement observed is for the most part agreement in the fact that spall will not occur. Since the amount of rear-side spall also decreases as impact angle increases, the repeatability of spall not occurring will naturally increase as impact angle increases.

\subsubsection{Repeatability as Function of Projectile Diameter}

Based on Table 3.3 , both the perforation and the spallation repeatability indices increased as projectile diameter increased. This can be explained by considering the nature of pressure wall perforation as a function of impact energy, which is directly related to projectile diameter. When impact energy is relatively low, pressure wall perforation is driven by mechanical processes like fracture. These processes are very sensitive to mechanical or metallurgical imperfections so that in low energy impact, the repeatability of pressure wall perforation will be dependent on metallurgical consistency from test to test. If such consistency is not maintained, perforation repeatability in relatively low energy impacts (i.e. relatively 
small projectile diameters) will be relatively low. It is noted that when the impact energy is low enough so that perforation of the pressure wall is not likely to occur, we can expect repeatability to go up again since the response (i.e. non-perforation) will be more consistent. Alternatively, for a high energy impact, pressure wall perforation is driven by hydrodynamical considerations which are not as sensitive to mechanical defects as mechanical processes. Thus, for high energy impacts (i.e. for impacts with larger projectile diameters), the response will be relatively uniform.

\subsubsection{Repeatability as Function of Impact Velocity}

According to the arguments presented in the discussion of repeatability as a function of projectile diameter, it would be expected that repeatability would be relatively high for impact velocities below approximately 3 to 4 $\mathrm{km} / \mathrm{sec}$ and above approximately $6 \mathrm{~km} / \mathrm{sec}$. Between 3 and $6 \mathrm{~km} / \mathrm{sec}$, where mechanical processes dominate the perforation of the pressure wall plate, repeatability would be expected to be lower than in the other two cases. As can be seen in Tables $3.4 \mathrm{a}$ and $3.4 \mathrm{~b}$, this is indeed the case for dual-wall structures with MLI: the perforation Repeatability Index varies from $90 \%$ at impact velocities below $4 \mathrm{~km} / \mathrm{sec}$ to $57 \%$ for velocities between 5 and 6 $\mathrm{km} / \mathrm{sec}$ to $90 \%$ again for speeds in excess of $7 \mathrm{~km} / \mathrm{sec}$.

\subsubsection{Repeatability as Function of Bumper Thickness}

From Table 3.5 , it can be seen that the perforation Repeatability Index increases from only $50 \%$ at $t_{S}=1.02 \mathrm{~mm}$ to $80 \%$ at $t_{S}=2.03 \mathrm{~mm}$ for dual-wall structures with MLI. The scarcity of data for structures without MLI except in one test group prevents any conclusions from being drawn regarding the effect of bumper thickness on repeatability for such structures. With 
regard to spallation for dual-wall structures with MLI, the repeatability index starts out quite high for very thin bumper plates, decreases slightly as the bumper thickness increases, and then increases to a high level for the thickest bumper plate. Because MLI is present in these dual-wall systems, the agreement is with respect to the non-occurrence of rear-side spall; the spall that did occur in the tests with medium-thickness bumper plates was minimal. Therefore, the variation in the Repeatability Index for rear-side spall as a function of bumper thickness is not very significant. 
Table 3.1 Overview of Perforation and Spallation Repeatability

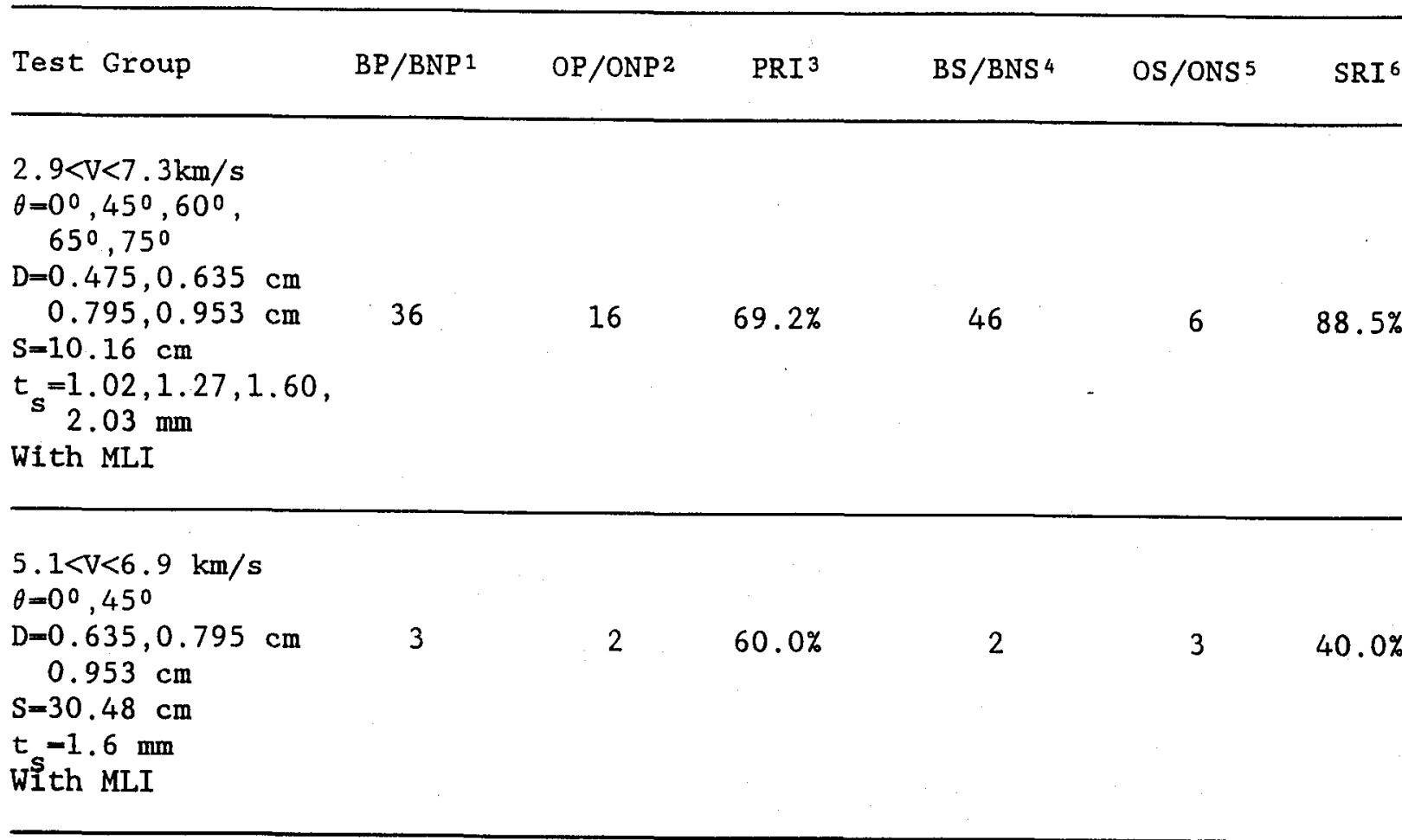

$3.6<\mathrm{V}<7.2 \mathrm{~km} / \mathrm{s}$

$\theta=00,30^{\circ}$

$D=0.475,0.635 \mathrm{~cm}$

$\begin{array}{lllllll}0.795 \mathrm{~cm} & 10 & 2 & 83.3 \% & 12 & 0 & 100.0 \%\end{array}$

$\mathrm{S}=10.16 \mathrm{~cm}$

$t_{s}=1.60,2.03 \mathrm{~mm}$

WIs thout MLI

$3.7<\mathrm{V}<7.1 \mathrm{~km} / \mathrm{s}$

$\theta=00$

$D=0.475,0.635 \mathrm{~cm}$

$\mathrm{S}=15.24 \mathrm{~cm}$

$t_{s}=1.6 \mathrm{~mm}$

Wis thout MLI

$\begin{array}{llllll}4 & 3 & 57.1 \% & 3 & 4 & 42.9 \%\end{array}$

Without MII

Overall

53

23

$69.7 \%$

63

13

$82.9 \%$

1Both tests perforated or both tests not perforated

2 One test perforated and one test not perforated

3 Perforation Repeatability Index

4 Both tests spalled or both tests not spalled

5 One test spalled and one test not spalled

${ }^{6}$ Spallation Repeatability Index 
Table 3.2 Perforation and Spallation Repeatability as a Function of Impact Angle ( $\mathrm{S}=10.16 \mathrm{~cm})$

\begin{tabular}{|c|c|c|c|c|c|c|}
\hline Test Group & $\mathrm{BP} / \mathrm{BNP}$ & OP/ONP & PRI & BS / BNS & os/ONS & SRI \\
\hline \multicolumn{7}{|c|}{$\theta=0^{\circ}, 30^{\circ}$} \\
\hline $\begin{array}{l}.9<\mathrm{V}<7.3 \mathrm{~km} / \mathrm{s} \\
D=0.475,0.635 \mathrm{~cm} \\
0.795,0.953 \mathrm{~cm} \\
t^{s}=1.02,1.60 \mathrm{~mm} \\
\text { With MLI }\end{array}$ & 18 & 7 & $72.0 \%$ & 23 & 2 & $92.0 \%$ \\
\hline $\begin{array}{l}3.6<\mathrm{V}<7.2 \mathrm{~km} / \mathrm{s} \\
\mathrm{D}-0.475,0.635 \mathrm{~cm} \\
\quad 0.795 \mathrm{~cm} \\
\mathrm{t}=1.60,2.03 \mathrm{~mm} \\
\text { Without MLI }\end{array}$ & 7 & 2 & $77.8 \%$ & 9 & 0 & $100.0 \%$ \\
\hline
\end{tabular}

$\theta=45^{\circ}$

$3.1<\mathrm{V}<6.9 \mathrm{~km} / \mathrm{s}$

$\mathrm{D}=0.475,0.635 \mathrm{~cm}$

$0.953 \mathrm{~cm}$

13

$6 \quad 72.2 \%$

16

3

$88.9 \%$

$t-1.27,2.03 \mathrm{~mm}$

Wîth MLI

$6.6<\mathrm{V}<7.0 \mathrm{~km} / \mathrm{s}$

$\mathrm{D}=0.635,0.795 \mathrm{~cm}$

$t=1.60 \mathrm{~mm}$

2

0

(1) 7

2

0

(1) 7

Wisthout MLI

$\theta=60^{\circ}, 65^{\circ}, 75^{\circ}$

$2.9<V<6.5 \mathrm{~km} / \mathrm{s}$

$\mathrm{D}=0.635,0.795 \mathrm{~cm}$

$t_{s}=1.02,1.27 \mathrm{~mm}$

$2.03 \mathrm{~mm}$

With MLI

$7.1<\mathrm{V}<7.3 \mathrm{~km} / \mathrm{s}$

$\mathrm{D}=0.475 \mathrm{~cm}$

10

(1)

1

0

(1)

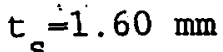

Wisthout MLI

Overall

46

18

$71.9 \%$

59

5

$92.2 \%$

7 Sufficient no. of tests not available for Repeatability Index calculation 
Table 3.3 Perforation and Spallation Repeatability as a

Function of Projectile Diameter $(\mathrm{S}=10.16 \mathrm{~cm})$

\begin{tabular}{ccccccc}
\hline Test Group & BP/BNP & OP/ONP & PRI & BS/BNS & OS/ONS & SRI \\
\hline & $D=0.475 \mathrm{~cm}$ & & \\
\hline
\end{tabular}

$6.4<\mathrm{V}<7.3 \mathrm{~km} / \mathrm{s}$

$\theta=00,45^{\circ}$

$t_{s}=1.02,2.03 \mathrm{~mm}$

$\begin{array}{lllll}1 & 1 & (1) & 2 & 0\end{array}$

(1)

Wîth MLI

$3.6<\mathrm{V}<7.3 \mathrm{~km} / \mathrm{s}$

$\theta=00,650$

$t_{s}=1.60,2.03 \mathrm{~mm}$

$\begin{array}{llllll}2 & 1 & 66.7 \% & 3 & 0 & 100.0 \%\end{array}$

Wisthout MLI

$\mathrm{D}=0.635 \mathrm{~cm}$

$2.9<\mathrm{V}<6.9 \mathrm{~km} / \mathrm{s}$

$\theta=00,45^{\circ}, 65^{\circ}$

$t_{s}=1.02,1.27 \mathrm{~mm}$

$1.60,2.03 \mathrm{~mm}$

16

10

$61.5 \%$

21

5

$76.9 \%$

With MLI

$4.9<\mathrm{V}<7.2 \mathrm{~km} / \mathrm{s}$

$\theta=0^{\circ}, 30^{\circ}, 45^{\circ}$

$t=1.60 \mathrm{~mm}$

4

$1 \quad 80.0 \%$

5

$0 \quad 100.0 \%$

Wis thout MLI

$\mathrm{D}=0.795,0.953 \mathrm{~cm}$

$2.9<\mathrm{V}<7.2 \mathrm{~km} / \mathrm{s}$

$\theta=00,45^{\circ}, 60^{\circ}, 75^{\circ}$

$t_{s}=1.02,1.27 \mathrm{~mm}$

$1.60,2.03 \mathrm{~mm}$

19

$5 \quad 79.2 \%$

24

$0 \quad 100.0 \%$

With MLI

$4.3<V<6.8 \mathrm{~km} / \mathrm{s}$

$\theta=00,45^{\circ}$

$t_{s}=1.60 \mathrm{~mm}$

$\begin{array}{llllll}4 & 0 & 100.0 \% & 4 & 0 & 100.0 \%\end{array}$

Wisthout MLI

\begin{tabular}{lllllll}
\hline Overall & 46 & 18 & $71.9 \%$ & 59 & 5 & $92.2 \%$ \\
\hline
\end{tabular}


Table 3.4a Perforation and Spallation Repeatability as a Function of Impact Velocity $(\mathrm{S}=10.16 \mathrm{~cm}, 2.9<\mathrm{V}<6 \mathrm{~km} / \mathrm{sec})$

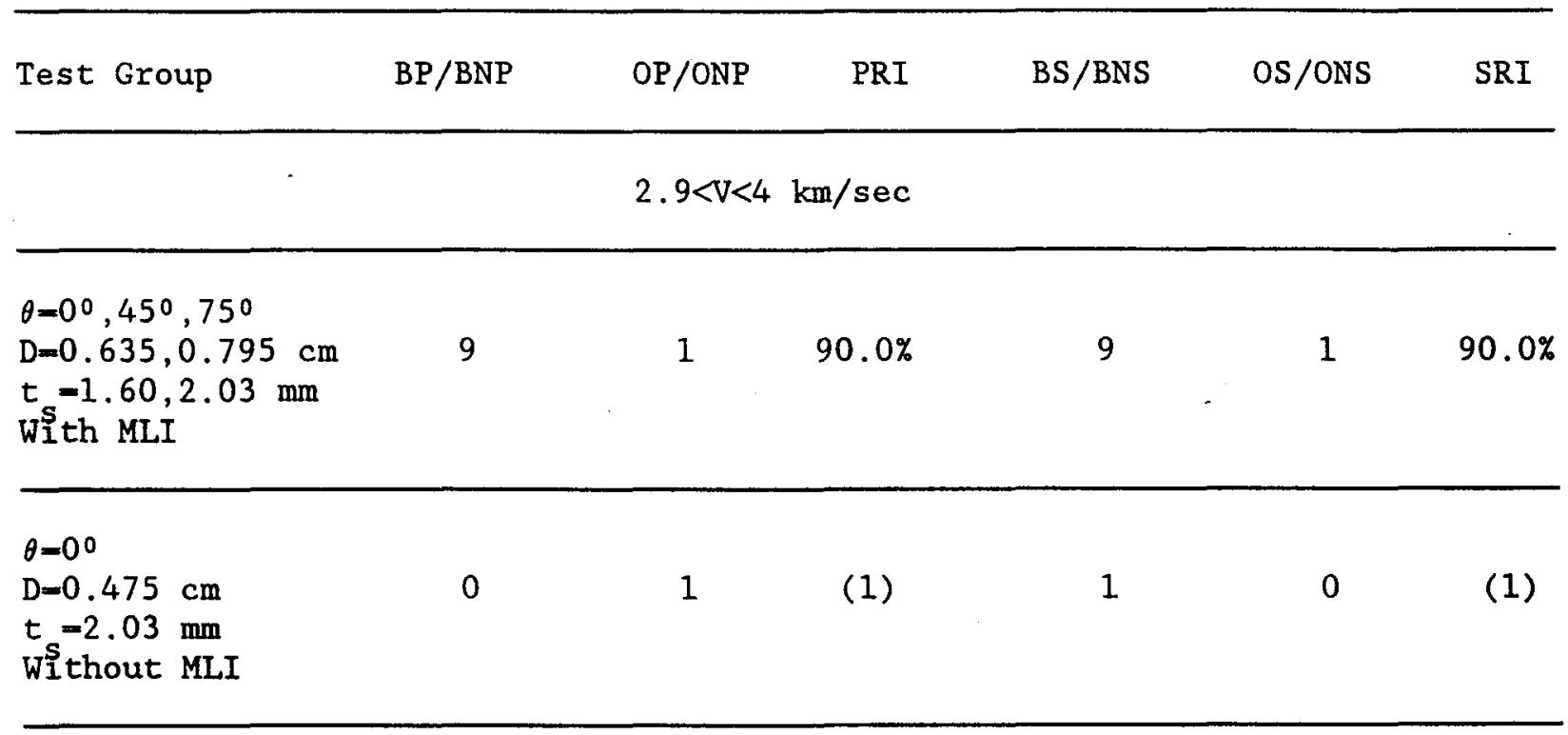

$4<\mathrm{V}<5 \mathrm{~km} / \mathrm{sec}$

\begin{tabular}{|c|c|c|c|c|}
\hline $\begin{array}{l}\theta=0^{0}, 65^{\circ} \\
D=0.635 \mathrm{~cm}\end{array}$ & 1 & 1 & (1) & 1 \\
\hline
\end{tabular}

$\theta=00$

$\mathrm{D}=0.475,0.635 \mathrm{~cm}$

$0.795 \mathrm{~cm}$

$t_{s}=1.60,2.03 \mathrm{~mm}$

$\begin{array}{lllll}3 & 0 & 100.0 \% & 3 & 0\end{array}$

Wisthout MLI

$5<\mathrm{V}<6 \mathrm{~km} / \mathrm{sec}$

$\theta=450$

$\mathrm{D}-0.635 \mathrm{~cm}$

$t_{\mathrm{s}}=1.27 \mathrm{~mm}$

With MLI

$\begin{array}{llllll}4 & 3 & 57.1 \% & 4 & 3 & 57.1 \%\end{array}$

Without MLI

N/A N/A

N/A

N/A

N/A

N/A 
Table 3.4b Perforation and Spallation Repeatability as a Function of Impact Velocity ( $\mathrm{S}=10.16 \mathrm{~cm}, 6<\mathrm{V}<8 \mathrm{~km} / \mathrm{sec})$

\begin{tabular}{|c|c|c|c|c|c|c|}
\hline Test Group & $\mathrm{BP} / \mathrm{BNP}$ & OP/ONP & PRI & BS/BNS & OS/ONS & SRI \\
\hline \multicolumn{7}{|c|}{$6<V<7 \mathrm{~km} / \mathrm{sec}$} \\
\hline $\begin{array}{l}\theta=0^{0}, 45^{\circ}, 75^{\circ} \\
D=0.475,0.635 \mathrm{~cm} \\
0.795,0.953 \mathrm{~cm} \\
t_{\mathrm{s}}=1.02,1.27 \mathrm{~mm} \\
1.60,2.03 \mathrm{~mm} \\
\text { With MLI }\end{array}$ & 15 & 10 & $60.0 \%$ & 24 & 0 & $100.0 \%$ \\
\hline $\begin{array}{l}\theta=00,300,450 \\
D=0.635,0.795 \mathrm{~cm} \\
t_{s}=1.60 \mathrm{~mm} \\
\text { Without MLI }\end{array}$ & 5 & 1 & $83.3 \%$ & 6 & 0 & $100.0 \%$ \\
\hline \multicolumn{7}{|c|}{$7<\mathrm{V}<8 \mathrm{~km} / \mathrm{sec}$} \\
\hline $\begin{array}{l}\theta=00 \\
D=0.475,0.795 \mathrm{~cm} \\
t=1.02,1.60 \mathrm{~mm} \\
\text { With MLI }\end{array}$ & 7 & 1 & $87.5 \%$ & 9 & 0 & $100.0 \%$ \\
\hline $\begin{array}{l}\theta=30^{\circ}, 650 \\
D=0.475,0.635 \mathrm{~cm} \\
t=1.60 \mathrm{~mm} \\
\text { Without MLI }\end{array}$ & 2 & 0 & (1) & 2 & 0 & $(1)$ \\
\hline Overall ${ }^{\dagger}$ & 46 & 18 & $71.9 \%$ & 49 & 5 & $92.2 \%$ \\
\hline
\end{tabular}


Table 3.5 Perforation and Spallation Repeatability as a

Function of Bumper Thickness ( $\mathrm{S}=10.16 \mathrm{~cm}$ )

\begin{tabular}{|c|c|c|c|c|c|c|}
\hline Test Group & $\mathrm{BP} / \mathrm{BNP}$ & OP/ONP & PRI & BS/BNS & OS/ONS & SRI \\
\hline \multicolumn{7}{|c|}{$t_{s}=1.02 \mathrm{~mm}$} \\
\hline $\begin{array}{l}4.6<V<7.3 \mathrm{~km} / \mathrm{s} \\
D=0.475,0.635 \mathrm{~cm} \\
\quad 0.795 \mathrm{~cm} \\
\theta=00,650 \\
\text { With MLI }\end{array}$ & 3 & 3 & $50.0 \%$ & 6 & 0 & $100.0 \%$ \\
\hline Without MLI & $\mathrm{N} / \mathrm{A}$ & $\mathrm{N} / \mathrm{A}$ & $\mathrm{N} / \mathrm{A}$ & $\mathrm{N} / \mathrm{A}$ & $\mathrm{N} / \mathrm{A}$ & $\mathrm{N} / \mathrm{A}$ \\
\hline \multicolumn{7}{|c|}{$t_{s}=1.27 \mathrm{~mm}$} \\
\hline $\begin{array}{l}2.9<\mathrm{V}<6.4 \mathrm{~km} / \mathrm{s} \\
\mathrm{D}=0.635,0.953 \mathrm{~cm} \\
\theta=45^{\circ}, 60^{\circ} \\
\text { With MLI }\end{array}$ & 8 & 7 & $53.3 \%$ & 12 & 3 & $80.0 \%$ \\
\hline Without MLI & $\mathrm{N} / \mathrm{A}$ & $\mathrm{N} / \mathrm{A}$ & N/A & N/A & N/A & $\mathrm{N} / \mathrm{A}$ \\
\hline
\end{tabular}

$2.9<\mathrm{V}<7.2 \mathrm{~km} / \mathrm{s}$

$\mathrm{D}=0.635,0.795 \mathrm{~cm}$

$\begin{array}{lllllll}0.953 \mathrm{~cm} & 17 & 4 & 80.9 \% & 19 & 2 & 90.4 \%\end{array}$

$\theta=00$

With MLI

$4.3<\mathrm{V}<7.3 \mathrm{~km} / \mathrm{s}$

$\mathrm{D}=0.475,0.635 \mathrm{~cm}$

$0.795 \mathrm{~cm}$

$\theta=00,30^{\circ}, 45^{\circ}, 65^{\circ}$

9

$190.0 \%$

10

$0 \quad 100.0 \%$

Without MLI

$t_{s}=2.03 \mathrm{~mm}$

$3.1<\mathrm{V}<6.9 \mathrm{~km} / \mathrm{s}$

$\mathrm{D}=0.475,0.635 \mathrm{~cm}$

$0.795 \mathrm{~cm}$

$\theta=45^{\circ}, 75^{\circ}$

8

$2 \quad 80.0 \%$

10

$0 \quad 100.0 \%$

With MLI

$3.6<\mathrm{V}<4.3 \mathrm{~km} / \mathrm{s}$

$\mathrm{D}=0.475 \mathrm{~cm}$

$\theta=0^{\circ}$

11

(1)

2

0

(1)

Without MLI

\begin{tabular}{lllllll}
\hline Overal1 & 46 & 18 & $71.9 \%$ & 59 & 5 & $92.2 \%$ \\
\hline
\end{tabular}




\subsection{Results and Discussion - Uncertainty Analysis}

\subsubsection{Introductory Comments}

This section consists of a discussion of the results obtained using the two approaches to the data uncertainty analysis developed in Section 3.3.3. Also presented are several examples using the equations derived and the information provided in Tables 3.6-3.9. The use of the Tables and equations for the two approaches is demonstrated first, followed by a-discussion of the observable trends in the uncertainty analysis data. It is noted that in Table 3.7, for a non-zero impact angle, the first and second lines of information pertain to the minimum and maximum hole dimensions, respectively.

\subsubsection{Illustrative Examples -- First Approach}

The data in Tables $3.6-3.9$ can be used to calculate intervals within which a certain percentage of response parameter ratios can be expected to lie, given a certain level of confidence. Alternatively, the specified confidence level is the probability that the a particular response parameter ratio is within the calculated interval. In either case, it is assumed that there is no fixed or bias error present in the experimental readings.

As an example, consider a test series in which $0.795 \mathrm{~cm}(0.313 \mathrm{in.})$ diameter projectiles normally impact a dual-wall system at a speed of 6.5 $\mathrm{km} / \mathrm{sec}$. We wish to know what are the extents of the intervals within which 1ie $75 \%$ and $90 \%$ of the bumper plate hole diameter ratios for the given impact conditions. Using equation (3) together with the values of $\mu_{\rho<1}, \sigma_{\rho<1}$ and $\mu_{\rho>1}, \sigma_{\rho>1}$ in Table 3.7 for a $0^{\circ}$ impact, we have

$$
0.944-0.050 \eta_{c}<\rho_{0}<1.062+0.058 \eta_{c}
$$

where $\eta_{c}$ is dependent on the specified level of confidence ' $c$ ' and the 
number of degrees of freedom $\mathrm{n}=\mathrm{N}-1$ in the test group under consideration. In this case, $N=20$ so that $n=19$; if we specify a $75 \%$ confidence level, then from Table 3.6 we see that $\eta_{0}=0.688$. Substituting $\eta_{c}=0.688$ into equation (4) tells us that there is a $75 \%$ probability that, if fixed errors ir lata collection are ignored, the ratio of the bumper plate hole diameters Eor two additional tests at similar impact conditions will lie between 0.906 and 1.102 .

For a $90 \%$ confidence level, Table 3.6 tells us that $\eta_{c}=1.328$. Substituting this value into equation (6) results in an interval that extends from 0.878 to 1.139 . In this case, as for the previous confidence level considered, the extent of the interval about unity is relatively small (oniy $10-12 \%$ on either side of unity). This is due to the small deviations of the ratios of recorded hole diameter ratios about a value of 1.0 as is evidenced by the proximity of the means $\mu_{\rho<1}$ and $\mu_{\rho>1}$ to 1.0 and the small values of the standard deviations $\sigma_{\rho<1}$ and $\sigma_{\rho>1}$ in Table 3.7.

The same procedure can be used to determine modified confidence intervals for the pressure wall hole diameter data (in the event of a perforation) and the pressure wall damage area data. For example, for a test series using dual-wall systems with MLI at $V=6.5 \mathrm{~km} / \mathrm{sec}$ where pressure wall perforation does occur, equation (3) and the information in Table 3.8 yields

$$
0.712-0.301 \eta_{\mathrm{c}}<\rho_{\mathrm{o}}<1.398+0.150 \eta_{\mathrm{c}}
$$

For a 75\% confidence level with, in this case, $n=13-1=12$, Table 3.6 tellis us that $\eta_{c}=0.695$. Thus, the $75 \%$ modified confidence interval for a test series under these conditions extends from 0.503 to 1.502 . In turn, this tells us that there is a $75 \%$ probability that the ratio between the 
pressure wall hole diameters in two tests in which perforation had occurred will lie between 0.503 and 1.502. Similarly, for a test on dual-wall structure with MLI and in which $t_{s}=0.050$ in., equation (3) and the information in Table 3.9 yield the equation

$$
0.777-0.277 \eta_{c}<\rho_{o}<1.280+0.367 \eta_{c}
$$

For a $75 \%$ confidence interval with, in this case, $n=14-1=13$, Table 3.6 tells us that $\eta_{c}=0.694$. This results in a $75 \%$ modified confidence interval that extends from 0.585 to 1.534 .

As can be seen from these examples, the extent of the modified confidence intervals for the pressure wall hole diameter and damage area data are significantly larger than that for the bumper plate hole diameter data for the same level of confidence. Possible explanations for this as well as a discussion of other observed trends in the uncertainty analysis data are presented in Section 3.5.4.

\subsubsection{Illustrative Examples - - Second Approach}

The data in Tables $3.6-3.9$ can also be used to calculate intervals within which it may supposed that the 'true' value of a response parameter lies, given a certain level of confidence. Alternatively, the specified confidence level is the probability that the supposed 'true' value of a response parameter is within the calculated interval. In either case, as before, it is assumed that there is no fixed or bias error present in the experimental readings.

For the first example, consider Test No. ESSH-6A (see Section 3.8, Table 3.11) in which a $0.795 \mathrm{~cm}(0.313 \mathrm{in.})$ diameter projectile normally 
impacted a dual-wall system at a speed of $6.55 \mathrm{~km} / \mathrm{sec}$. The recorded diameter of the hole in the bumper plate is $1.636 \mathrm{~cm}(0.644 \mathrm{in})$. We wish to know how representative of the actual or true bumper plate hole diameter is the recorded value for the given impact conditions. Using equation ( 5 ), we can determine an interval for a given level of confidence within which the true value of hole diameter for the given conditions is expected to he. Specifically, using the values of $\mu_{\rho<1}, \sigma_{\rho<1}$ and $\mu_{\rho>1}, \sigma_{\rho>1}$ in Table 3.7 for a $0^{\circ}$ impact, equation (5) becomes

$$
0.944-0.050 \eta_{c}<\rho_{0}<1.062+0.058 \eta_{c}
$$

where $\eta_{c}$ is dependent on the specified level of confidence ' $c$ ' and the number of degrees of freedom $n=N-1$ in the test group under consideration. In this case, $\mathrm{N}=20$ so that $\mathrm{n}=19$; if we specify a $75 \%$ confidence level, then from Table 3.6 we see that $\eta_{c}=0.688$. Substituting $\eta_{c}=0.688$ into equation (9) tells us that there is a $75 \%$ probability that, if fixed errors in data collection are ignored, the actual or true value of the bumper hole diameter lies between 0.906 and 1.102 times the recorded value, or between 1.481 and $1.801 \mathrm{~cm}(0.583$ and $0.709 \mathrm{in.})$.

For this example, if we wish to increase our confidence in the interval within which the true value of hole diameter lies, then that interval must increase in size. Thus, for a $90 \%$ confidence level, Table 3.6 tells us that $\eta_{c}=1.328$. Substituting this value into equation (9) results in an interval that extends from 0.878 to 1.139 times the recorded value or between 1.435 and $1.864 \mathrm{~cm}(0.565$ and $0.734 \mathrm{in.})$. In this case, as for the previous confidence level considered, the extent of the interval about the recorded value is relatively small (only $10-12 \%$ on either side of the recorded 
value). This is due to the small deviations of the ratios of recorded hole diameters about a value of 1.0 as is evidenced by the proximity of the means $\mu_{\rho<1}$ and $\mu_{\rho>1}$ to 1.0 and the small values of the standard deviations $\sigma_{\rho<1}$ and $\sigma_{\rho>1}$ in Table 3.7 .

The same procedure can be used to determine modified confidence intervals for the pressure wall hole diameter data (in the event of a perforation) and the pressure wall damage area data. For example, for a test on a dual-wall system with MLI at V=6.5 km/sec where pressure wall perforation occurs, equation (5) and the information in Table 3.8 yields

$$
0.712-0.301 \eta_{c}<\rho_{o}<1.398+0.150 \eta_{c}
$$

For a $75 \%$ confidence level with, in this case, $n=13-1=12$, Table 3.6 tells us that $\eta_{c}-0.695$. Thus, the true value of pressure wall hole diameter for a test in which perforation occurs would lie between 0.503 and 1.502 times a recorded value. Similarly, for a test on dual-wall structure with MLI and in which $t_{s}=0.050$ in., equation (5) and the information in Table 3.9 yield the equation

$$
0.777-0.277 \eta_{c}<\rho_{o}<1.280+0.367 \eta_{c}
$$

For a $75 \%$ confidence interval with, in this case, $n=14-1=13$, Table 3.6 tells us that $\eta_{c}=0.694$. This implies that the true value of pressure wall damage area would lie between 0.585 and 1.534 times the recorded value.

\section{5 .4 Observations on the Data}

As can be seen by inspecting the value of the means and standard deviations in for the various test groups in Table 3.7-3.9, the level of uncertainty in the response data can vary significantly depending on the 
response considered. Specifically, as stated previously, the means of the bumper plate diameter data are all fairly close to 1.0 and the standard deviations are all fairly small (Table 3.8). This implies that we can be fairly confident that the recorded values of bumper plate hole diameto. are fairly consistent and may indeed be representative of the actual or true hole diameter values. However, this is not necessarily the case for the pressure wall hole diameter or pressure wall damage area values: there can be a significant amount of uncertainty in the pressure wall response data. This issue is discussed in detail in the following paragraphs.

For pressure wall hole diameter in the event of a perforation (Table 3.8 ), the means are larger and the standard deviations are smaller for $0^{\circ}$ impacts than for $45^{\circ}$ impacts. For pressure wall damage area (Table 3.9), they are similar for $0^{\circ}$ and $45^{\circ}$ impacts but in general smaller than those for $60^{\circ}, 65^{\circ}$, and $75^{\circ}$ impacts. Tests with lower impact velocities (ie. below approximately $5.5 \mathrm{~km} / \mathrm{sec}$ ) also exhibited less variability in pressure wall hole diameter data than did tests with impact velocities above $5.5 \mathrm{~km} / \mathrm{sec}$ (Table 3.8); however, the variability in pressure wall damage area data was approximately the same for all impact velocities. In terms of bumper thickness, the variability in the pressure wall hole diameter and damage area data decreased (ie. larger means, smaller standard deviations) as bumper thickness increased. As a function of projectile diameter, the variability in the data was relatively the similar for the 0.635 and $0.795 \mathrm{~cm}(0.250$ and 0.313 in.) diameter projectiles, but smaller than that for those with a $0.475 \mathrm{~cm}(0.187 \mathrm{in.})$ diameter.

The observations in the previous paragraph can be explained by the 
following considerations. First, at lower impact velocities and in normal impacts there are fewer competing processes at work during the impact event than at higher impact velocities (where fragmentation and melting occur simultaneously) and in oblique impacts (where two or three debris clouds are created instead of just one). This would result in more consistent pressure wall response values such as hole diameter and damage area. Second, the larger projectiles were deformed less in their flights through the light gas gun than were the $0.475 \mathrm{~cm}(0.187 \mathrm{in}$.) diameter projectile. This in-flight projectile deformation for the smaller projectiles naturally affected the orientation of the smaller projectile at impact which significantly affected the consistency of system response in such cases.

While the information presented in Tables 3.7-3.9 has been used in this report to assess the uncertainty in the impact test data obtained thus far, it also can be used in another related manner. Specifically, the data in Tables 3.7-3.9 to provide insight into the sensitivity of dual-wall system response to minute differences in impact conditions, material composition, specimen thickness, etc. This use of the data is discussed in the following paragraphs.

Consider a response paramter, such as bumper plate hole diameter, whose modified confidence interval is relatively small (e.g. $\pm 10 \%$ ) at a relatively high confidence level (e.g. 90\%). In this case, it can be said that the parameter is relatively insensitive to small changes such as those listed in the previous paragraph, and that the data for this parameter are expected to be consistent from one test to another, despite the fact that there may be small unavoidable differences present. This in turn implies that a relatively small number of tests will be required to characterize such a para- 
meter under the test conditions of interest.

Alternatively, consider a response parameter, such as pressure wall damage area, whose modified confidence interval is relatively large (e.g. $\pm 50 \%$ ) even at relatively low confidence levels (e.g. $75 \%$ ). In this case, it may be argued that the parameter is in fact highly sensitive to minute changes in test conditions. The data for this parameter are highly scattered and are not expected to be consistent from one test to another. However, this does not imply that there is necessarily anything wrong with the data. On the contrary, the results of the individual tests are appropriate for the specific conditions of a specific test. For such a response parameter, small unavoidable variations from test to test will apparently result in differences in response which will in turn result in the unsightly scatter of the test data. The final implication is that a relatively large number of tests will be required to characterize such a response parameter under the test conditions of interest. 
Table 3.6 Values of $\eta_{c}$ as a Function of Number-of-Degrees-of-Freedom ( $n$ ) and Confidence Level (c) [3.2]

\begin{tabular}{|c|c|c|c|c|c|c|c|c|}
\hline$n)^{c}$ & .60 & .75 & .90 & .95 & .975 & .99 & .995 & .9995 \\
\hline 1 & .325 & 1.000 & 3.078 & 6.314 & 12.706 & 31.821 & 63.657 & 636.619 \\
\hline 2 & .289 & .816 & 1.886 & 2.920 & 4.303 & 6.965 & 9.925 & 31.598 \\
\hline 3 & .277 & .765 & 1.638 & 2.353 & 3.182 & 4.541 & 5.841 & 12.924 \\
\hline 4 & .271 & .741 & 1.533 & 2.132 & 2.776 & 3.747 & 4.604 & 8.610 \\
\hline 5 & .267 & 727 & 1.476 & 2.015 & 2.571 & 3.365 & 4.032 & 6.869 \\
\hline 6 & 265 & .718 & 1.440 & 1.943 & 2.447 & 3.143 & $3.70 i$ & 5.959 \\
\hline 7 & .263 & .711 & 1.415 & 1.895 & 2.365 & 2.998 & 3.499 & 5.408 \\
\hline 8 & .262 & .706 & 1.397 & 1.860 & 2.306 & 2.896 & 3.355 & 5.041 \\
\hline 9 & .261 & .703 & 1.383 & 1.833 & 2.262 & 2.821 & 3.250 & 4.781 \\
\hline 10 & 260 & .700 & 1.372 & 1.812 & 2.228 & 2.764 & 3.169 & 4. 587 \\
\hline 11 & .260 & 697 & 1.363 & 1.796 & 2.201 & 2.718 & 3.106 & 4.437 \\
\hline 12 & .259 & 695 & 1.356 & 1.782 & 2.179 & 2.681 & 3.055 & 4.318 \\
\hline 13 & .259 & .694 & 1.350 & 1.771 & 2.160 & 2.650 & 3.012 & 4,221 \\
\hline 14 & .258 & 692 & 1.345 & 1.761 & 2.145 & 2.624 & 2.977 & 4.140 \\
\hline 15 & .258 & 691 & 1.341 & 1.753 & 2.131 & 2.602 & 2.947 & 4.073 \\
\hline 16 & .258 & 690 & 1.337 & 1.746 & 2.120 & 2.583 & 2.921 & 4.015 \\
\hline 17 & .257 & 689 & 1.333 & 1.740 & 2.110 & 2.567 & 2.898 & 3.965 \\
\hline 18 & .257 & 6888 & 1.330 & 1.734 & 2.101 & 2.552 & 2.878 & 3.922 \\
\hline 19 & .257 & 688 & 1.328 & 1.729 & 2.093 & 2.539 & 2.861 & 3.883 \\
\hline 20 & .257 & 687 & 1.325 & 1.725 & 2.086 & 2.528 & 2.845 & 3.850 \\
\hline 21 & .257 & 686 & 1.323 & 1.721 & 2.080 & 2.518 & 2.831 & 3.819 \\
\hline 22 & .256 & 686 & 1.321 & 1.717 & 2.074 & 2.508 & 2.819 & 3.792 \\
\hline 23 & .256 & 685 & 1.319 & 1.714 & 2.069 & 2.500 & 2.807 & 3.767 \\
\hline 24 & .256 & 685 & 1.318 & 1.711 & 2.064 & 2.492 & 2.797 & 3.745 \\
\hline 25 & .256 & 684 & 1.316 & 1.708 & 2.060 & 2.485 & 2.787 & 3.725 \\
\hline 26 & .256 & 684 & 1.315 & 1.706 & 2.056 & 2.479 & 2.779 & 3.707 \\
\hline 27 & .256 & 684 & 1.314 & 1.703 & 2.052 & 2.473 & 2.771 & 3.690 \\
\hline 28 & .256 & 683 & 1313 & 1.701 & 2.048 & 2.467 & 2.763 & 3.674 \\
\hline 29 & .256 & 683 & 1.311 & 1.699 & 2.045 & 2. 462 & 2.756 & 3.659 \\
\hline 30 & .256 & 683 & 1.310 & 1.697 & 2.042 & 2.457 & 2.750 & 3.646 \\
\hline 40 & .255 & 681 & 1.303 & 1.684 & 2.021 & 2.423 & 2.704 & 3.551 \\
\hline 60 & .254 & .679 & 1.296 & 1.671 & 2.000 & 2.390 & 2.660 & 3.460 \\
\hline 120 & .254 & . 677 & 1.289 & 1.658 & 1.980 & 2.358 & 2.617 & 3.373 \\
\hline$\infty$ & .253 & .674 & 1. 282 & 1.645 & 1.960 & 2.326 & 2.576 & 3.291 \\
\hline
\end{tabular}


Table 3.7 Bumper Plate Hole Diameter Ratio Uncertainty Data

\begin{tabular}{cccccc}
\hline$\theta$ & $N$ & $\mu_{\rho<1}$ & $\sigma_{\rho<1}$ & $\mu_{\rho>1}$ & $\sigma_{\rho>1}$ \\
\hline $0^{\circ}$ & 20 & 0.944 & 0.050 & 1.062 & 0.058 \\
$45^{\circ}$ & 18 & 0.940 & 0.060 & 1.068 & 0.074 \\
& & 0.953 & 0.036 & 1.051 & 0.040 \\
$60^{\circ}, 65^{\circ}$ & 9 & 0.937 & 0.055 & 1.070 & 0.067 \\
$75^{\circ}$ & & 0.937 & 0.049 & 1.070 & 0.058 \\
\hline
\end{tabular}


Table 3.8 Pressure Wall Hole Diameter Ratio Uncertainty Data

\begin{tabular}{|c|c|c|c|c|c|c|}
\hline & MLI & $N$ & $\mu_{\rho<1}$ & $\sigma_{\rho<1}$ & $\mu_{\rho>1}$ & $\sigma_{\rho>1}$ \\
\hline \multicolumn{7}{|c|}{ As a Function of Impact Angle $\theta$ (in degrees) } \\
\hline$\theta=0^{\circ}$ & $\begin{array}{l}\mathrm{Y} \\
\mathrm{N}\end{array}$ & $\begin{array}{r}11 \\
5\end{array}$ & $\begin{array}{l}0.855 \\
0.723\end{array}$ & $\begin{array}{l}0.117 \\
0.147\end{array}$ & $\begin{array}{l}1.152 \\
1.439\end{array}$ & $\begin{array}{l}0.185 \\
0.343\end{array}$ \\
\hline$\theta=45^{\circ}$ & $Y$ & 7 & 0.698 & 0.250 & 1.616 & 0.613 \\
\hline \multicolumn{7}{|c|}{ As a Function of Bumper Thickness $t_{s}$ (in inches) } \\
\hline$t_{s}=0.050$ & $\begin{array}{l}\mathrm{Y} \\
\mathrm{N}\end{array}$ & 4 & $\begin{array}{c}0.601 \\
\ldots\end{array}$ & 0.272 & 1.887 & 0.675 \\
\hline$t_{s}=0.080$ & $\begin{array}{l}\mathrm{Y} \\
\mathrm{N}\end{array}$ & 3 & 0.827 & 0.181 & 1.253 & 0.305 \\
\hline \multicolumn{7}{|c|}{ As a Function of Impact Velocity $V$ (in $\mathrm{km} / \mathrm{sec}$ ) } \\
\hline $3<V<5.5$ & $\begin{array}{l}\mathrm{Y} \\
\mathrm{N}\end{array}$ & $\begin{array}{l}5 \\
2\end{array}$ & $\begin{array}{l}0.854 \\
0.822\end{array}$ & $\begin{array}{l}0.093 \\
0.038\end{array}$ & $\begin{array}{l}1.184 \\
1.218\end{array}$ & $\begin{array}{l}0.150 \\
0.056\end{array}$ \\
\hline $5.5<V<8$ & $\begin{array}{l}\mathrm{Y} \\
\mathrm{N}\end{array}$ & $\begin{array}{r}13 \\
3\end{array}$ & $\begin{array}{l}0.712 \\
0.656\end{array}$ & $\begin{array}{l}0.301 \\
0.162\end{array}$ & $\begin{array}{l}1.398 \\
1.586\end{array}$ & $\begin{array}{l}0.150 \\
0.391\end{array}$ \\
\hline As & $\mathrm{Fu}$ & on & Project & Diamet & $D$ (in $j$ & es) \\
\hline$D=0.250$ & $\begin{array}{l}\mathrm{Y} \\
\mathrm{N}\end{array}$ & $\begin{array}{l}8 \\
2\end{array}$ & $\begin{array}{l}0.735 \\
0.837\end{array}$ & $\begin{array}{l}0.235 \\
0.017\end{array}$ & $\begin{array}{l}1.522 \\
1.195\end{array}$ & $\begin{array}{l}0.592 \\
0.024\end{array}$ \\
\hline$D=0.313$ & $\begin{array}{l}\mathrm{Y} \\
\mathrm{N}\end{array}$ & $\begin{array}{l}8 \\
3\end{array}$ & $\begin{array}{l}0.646 \\
0.876\end{array}$ & $\begin{array}{l}0.146 \\
0.123\end{array}$ & $\begin{array}{l}1.169 \\
1.601\end{array}$ & $\begin{array}{l}0.221 \\
0.369\end{array}$ \\
\hline
\end{tabular}


Table 3.9 Pressure Wall Damage Area Ratio Uncertainty Data

\begin{tabular}{|c|c|c|c|c|c|c|}
\hline & MLI & $\mathrm{N}$ & $\mu_{\rho<1}$ & $\sigma_{\rho<1}$ & $\mu_{\rho>1}$ & $\sigma_{\rho>1}$ \\
\hline \multicolumn{7}{|c|}{ As a Function of Impact Angle $\theta$ (in degrees) } \\
\hline$\theta=0^{\circ}$ & $\begin{array}{l}\mathrm{Y} \\
\mathrm{N}\end{array}$ & $\begin{array}{r}21 \\
8\end{array}$ & $\begin{array}{l}0.746 \\
0.735\end{array}$ & $\begin{array}{l}0.223 \\
0.172\end{array}$ & $\begin{array}{l}1.510 \\
1.448\end{array}$ & $\begin{array}{l}0.610 \\
0.442\end{array}$ \\
\hline$\theta=45^{\circ}$ & $\begin{array}{l}\mathrm{Y} \\
\mathrm{N}\end{array}$ & $\begin{array}{l}18 \\
-\ldots\end{array}$ & $\begin{array}{c}0.864 \\
\ldots\end{array}$ & $\begin{array}{c}0.092 \\
-. .-\end{array}$ & $\begin{array}{c}1.170 \\
\ldots\end{array}$ & $\begin{array}{c}0.135 \\
-\end{array}$ \\
\hline $\begin{array}{l}\theta=60^{\circ} \\
65^{\circ}, 75^{\circ}\end{array}$ & $\begin{array}{l}\mathrm{Y} \\
\mathrm{N}\end{array}$ & $\begin{array}{c}8 \\
-\cdots\end{array}$ & $\begin{array}{c}0.571 \\
\ldots\end{array}$ & $\begin{array}{c}0.181 \\
\ldots\end{array}$ & $\begin{array}{c}1.953 \\
\ldots\end{array}$ & $\begin{array}{c}0.762 \\
\ldots\end{array}$ \\
\hline \multicolumn{7}{|c|}{ As a Function of Bumper Thickness $t_{s}$ (in inches) } \\
\hline$t_{s}=0.040$ & $\begin{array}{l}\mathrm{Y} \\
\mathrm{N}\end{array}$ & $\begin{array}{c}6 \\
--.\end{array}$ & $\begin{array}{c}0.610 \\
\ldots\end{array}$ & 0.240 & $\begin{array}{c}1.864 \\
\ldots\end{array}$ & $\begin{array}{c}0.699 \\
-.-\end{array}$ \\
\hline$t_{s}=0.050$ & $\begin{array}{l}\mathrm{Y} \\
\mathrm{N}\end{array}$ & 14 & $\begin{array}{c}0.777 \\
\ldots\end{array}$ & $\begin{array}{c}0.277 \\
\ldots .\end{array}$ & $\begin{array}{c}1.280 \\
\ldots-\end{array}$ & 0.367 \\
\hline$t_{s}=0.063$ & $\begin{array}{l}\mathrm{Y} \\
\mathrm{N}\end{array}$ & $\begin{array}{r}16 \\
8\end{array}$ & $\begin{array}{l}0.784 \\
0.689\end{array}$ & $\begin{array}{l}0.192 \\
0.166\end{array}$ & $\begin{array}{l}1.388 \\
1.534\end{array}$ & $\begin{array}{l}0.570 \\
0.399\end{array}$ \\
\hline$t_{s}=0.080$ & $\begin{array}{l}\mathrm{Y} \\
\mathrm{N}\end{array}$ & $\begin{array}{l}10 \\
\cdots\end{array}$ & $\begin{array}{c}0.739 \\
\ldots\end{array}$ & $\begin{array}{c}0.166 \\
\ldots-\end{array}$ & $\begin{array}{l}1.452 \\
\ldots .\end{array}$ & $\begin{array}{c}0.517 \\
\ldots\end{array}$ \\
\hline \multicolumn{7}{|c|}{ As a Function of Impact Velocity $V$ (in $\mathrm{km} / \mathrm{sec}$ ) } \\
\hline $3<V<5.5$ & $\begin{array}{l}\mathrm{Y} \\
\mathrm{N}\end{array}$ & $\begin{array}{r}12 \\
4\end{array}$ & $\begin{array}{l}0.776 \\
0.568\end{array}$ & $\begin{array}{l}0.226 \\
0.451\end{array}$ & $\begin{array}{l}1.448 \\
1.456\end{array}$ & $\begin{array}{l}0.612 \\
0.649\end{array}$ \\
\hline $5.5<V<8$ & $\begin{array}{l}\mathrm{Y} \\
\mathrm{N}\end{array}$ & $\begin{array}{r}34 \\
6\end{array}$ & $\begin{array}{l}0.763 \\
0.677\end{array}$ & $\begin{array}{l}0.185 \\
0.114\end{array}$ & $\begin{array}{l}1.442 \\
1.518\end{array}$ & $\begin{array}{l}0.490 \\
0.299\end{array}$ \\
\hline As & $\mathrm{aru}$ & ion & Project & Diamet & $D$ (in i & hes) \\
\hline$D=0.187$ & $\begin{array}{l}\mathrm{Y} \\
\mathrm{N}\end{array}$ & $-\cdot$ & 0.520 & 0.345 & 2.552 & 1.519 \\
\hline$D=0.250$ & $\begin{array}{l}\mathrm{Y} \\
\mathrm{N}\end{array}$ & $\begin{array}{r}25 \\
4\end{array}$ & $\begin{array}{l}0.803 \\
0.664\end{array}$ & $\begin{array}{l}0.181 \\
0.147\end{array}$ & $\begin{array}{l}1.338 \\
1.577\end{array}$ & $\begin{array}{l}0.432 \\
0.423\end{array}$ \\
\hline$D=0.313$ & $\begin{array}{l}\mathrm{Y} \\
\mathrm{N}\end{array}$ & $\begin{array}{r}18 \\
4\end{array}$ & $\begin{array}{l}0.725 \\
0.714\end{array}$ & $\begin{array}{l}0.194 \\
0.202\end{array}$ & $\begin{array}{l}1.514 \\
1.489\end{array}$ & $\begin{array}{l}0.555 \\
0.430\end{array}$ \\
\hline
\end{tabular}




\section{6 Concluding Comments}

By examining Tables $3.1-3.5$ and $3.7-3.9$, it is possible to see where additional testing is needed to supplement data already in existence. Additional data will allow the calculation of repeatability indices for test groups for which at present it is not possible. Specifically for dual-wall systems with a $10.16 \mathrm{~cm}$ stand-off distance without MLI, test results are needed at impact angles above $30^{\circ}$, with small and large projectiles, at impact velocities other than between 6 and $7 \mathrm{~km} / \mathrm{sec}$, and with bumper thicknesses other than $1.6 \mathrm{~mm}$. For similar systems with MLI, additional testing is needed at impact angles above $60^{\circ}$, with small projectile diameters, and also at speeds other than between 6 and $7 \mathrm{~km} / \mathrm{sec}$.

It should be noted that the variations in perforation and rear-side spallation indicated in the various Tables in Section 3.8 are probably not due to an inability to properly control the experimental parameters of the tests performed, Geometric parameters (thicknesses and wall-to-wall spacing), material properties (density, modulus, etc.) and impact conditions (diameter, angle, and velocity) can all be controlled to within acceptable tolerances. Rather, the variations observed are probably due to an factor that to date has not be measured, accounted for, or controlled. Such factors include manufacturing defects, metallurgical inconsistencies, and location of the initial impact on the bumper plate, to name a few. Increased attention must be paid to these and other here-to-fore unconsiderd factors if it is desired to increase the repeatability of the phenomena observed through hypervelocity impact testing using the NASA/MSFC light gas gun.

Finally, it is worthy of note that the observations made in the uncertainty analysis phase of this investigation reinforce those made during the 
repeatability phase of the study. Since both phases of the study utilized the same pool of data, this is hardly surprising. Specifically, both phases of this study conclude that repeatability increases (or, conversely, voriability decreases) as the impact angle decreases, the projectile diametef increases, and as the bumper thickness increases.

For impact velocity, the repeatability analysis show that repeatability was relatively similarly high for speeds below 4 to $5 \mathrm{~km} / \mathrm{sec}$ and above 6 $\mathrm{km} / \mathrm{sec}$ and relatively low for impact speeds between 5 and $6 \mathrm{~km} / \mathrm{sec}$. The uncertainty analysis showed lower variability in response for tests with impact velocities below approximately $5.5 \mathrm{~km} / \mathrm{sec}$ than for tests with velocities greater than $5.5 \mathrm{~km} / \mathrm{sec}$. While in not as great detail as are the results of the repeatability analysis for impact velocity, the results of the uncertainty analysis at least support those of the repeatability analysis in the lower impact velocity regime. The apparent contradiction at the higher impact velocities is probably due to the fact that all tests with velocities above $5.5 \mathrm{~km} / \mathrm{sec}$ were included in one test group in the uncertainty analysis and not broken down into two groups as in the repeatability study.

\subsection{References}

3.1 Coleman, H.W. and Steele, W.G., Experimentation and Uncertainty Analysis for Engineers, John Wiley, New York, 1989.

3.2 Fisher, R.A., and Yates, F., Statistical Tables, Oliver and Boyd, Ltd., London, 1938.

3.3 Schonberg, W.P., Bean, A.J., and Darzi, K., Hypervelocity Impact Physics, NASA CR-4343, January, 1991. 
3.8 Uncertainty Analysis Data Tables 


\begin{tabular}{|c|c|c|c|c|c|c|c|c|c|c|c|c|}
\hline $\begin{array}{r}\text { IMPACT } \\
\text { ANGLE } \\
\text { (DEG) }\end{array}$ & $\begin{array}{c}\text { PROJECTILE } \\
\text { DIAMETER } \\
\text { (IN) }\end{array}$ & $\begin{array}{c}\text { TEST } \\
\text { NUMBER }\end{array}$ & $\begin{array}{c}\text { IMPACT } \\
\text { VELOCITY } \\
\text { (KM/SEC) }\end{array}$ & $\begin{array}{l}\text { SHIELD } \\
\text { THICKNESS } \\
\text { (IN) }\end{array}$ & $\begin{array}{l}\text { STAND-OFF } \\
\text { DISTANCE } \\
\text { (IN) }\end{array}$ & $\begin{array}{c}\text { MLI } \\
\text { LOCATION }\end{array}$ & $\begin{array}{l}\text { BUMPER HOLE } \\
\text { DIAMETER } \\
\text { (IN) }\end{array}$ & $\begin{array}{l}\text { PRESSURE WALL } \\
\text { HOLE DIAMETER } \\
\text { (IN) }\end{array}$ & $\begin{array}{c}\text { NUMBER OF } \\
\text { HOLES }\end{array}$ & $\begin{array}{l}\text { DAMAGE } \\
\text { AREA } \\
\text { (SQ.IN.) }\end{array}$ & $\begin{array}{l}\text { MAXIMUM } \\
\text { PETAL LENGTH } \\
\text { (IN) }\end{array}$ & $\begin{array}{c}\text { SPALL } \\
\text { AREA } \\
\text { (SQ.IN.) }\end{array}$ \\
\hline \multirow[t]{2}{*}{0.000} & 0.250 & $3224 B$ & 5.260 & 0.063 & 12.000 & PWP & 0.521 & $\cdots$ & $\cdots$ & 41.280 & $\cdots$ & $\cdots$ \\
\hline & & $3224 \mathrm{~A}$ & 5.150 & 0.063 & 12.000 & PUP & 0.486 & 0.115 & 1 & 47.170 & $-\cdots$ & 0.010 \\
\hline \multirow[t]{2}{*}{0.000} & 0.313 & $3220 \mathrm{~A}$ & 5.960 & 0.032 & 12.000 & PWP & 0.474 & 0.073 & 2 & 30.680 & $\cdots$ & -- \\
\hline & & $3223 A$ & 5.850 & 0.032 & 12.000 & PHP & 0.595 & $\cdots$ & $\cdots$ & 45.720 & $-\cdot$ & 0.090 \\
\hline 0.000 & 0.375 & 3225 & 5.940 & 0.032 & 12.000 & PWP & 0.493 & 7.790 & 1 & 88.750 & 4.000 & $\cdots$ \\
\hline & & $3225 A$ & 5.910 & 0.032 & 12.000 & PWP & 0.483 & 6.630 & 1 & 34.520 & 2.300 & $\cdots$ \\
\hline 0.000 & 0.375 & $3226 B$ & 5.550 & 0.063 & 12.000 & PWP & 0.638 & 0.624 & 5 & 35.790 & $\cdots$ & $\cdots$ \\
\hline & & $3226 A$ & 5.620 & 0.063 & 12.000 & PWP & 0.618 & 0.187 & 3 & 88.580 & $\cdots$ & 0.090 \\
\hline 45.000 & 0.313 & $3133 c$ & 6.910 & 0.063 & 12.000 & PWP & $0.641 / 0.830$ & ---10.422 & $\cdots / 3$ & $16.76 / 11.05$ & $\cdots / \cdots$ & $-\cdots / \cdots$ \\
\hline & & 31330 & 6.780 & 0.063 & 12.000 & PWP & $0.642 / 0.818$ & $---/ 0.518$ & $\cdots / 3$ & $8.30 / 38.49$ & $\cdots / \cdots$ & $---/-\cdot$ \\
\hline \multirow{14}{*}{$\stackrel{\infty}{N}$} & 0.187 & P14 & 3.720 & 0.063 & 6.000 & $\cdots$ & 0.391 & 0.459 & 3 & 7.350 & $\ldots$ & $\cdots$ \\
\hline & & P14B & 3.710 & 0.063 & 6.000 & $\cdots$ & 0.417 & $\cdots$ & $\cdots$ & 20.910 & $\cdots$ & 0.050 \\
\hline & 0.187 & $2001 \mathrm{~A}$ & 3.770 & 0.063 & 6.000 & $\cdots$ & 0.353 & 0.273 & 2 & 23.760 & $\cdots$ & $\cdots$ \\
\hline & & 2001B & 3.930 & 0.063 & 6.000 & $\cdots$ & 0.350 & 0.204 & 2 & 41.280 & $\cdots$ & 0.040 \\
\hline & 0.187 & $2001 \mathrm{~A}$ & 3.770 & 0.063 & 6.000 & $\cdots$ & 0.353 & 0.273 & 2 & 23.760 & $\cdots$ & $\cdots$ \\
\hline & & $2001 C$ & 4.050 & 0.063 & 6.000 & $\cdots$ & 0.377 & $\cdots$ & $\cdots$ & 30.680 & -- & 0.010 \\
\hline & 0.187 & 2001B & 3.930 & 0.063 & 6.000 & $\cdots$ & 0.350 & 0.204 & 2 & 41.280 & $\cdots$ & 0.040 \\
\hline & & $2001 \mathrm{C}$ & 4.050 & 0.063 & 6.000 & $\cdots$ & 0.377 & $\cdots$ & $-\cdot$ & 30.680 & $\cdots$ & 0.010 \\
\hline & 0.187 & P24C & 5.800 & 0.063 & 6.000 & $\cdots$ & 0.560 & 0.190 & 3 & 22.370 & $\cdots$ & 0.480 \\
\hline & & P24F & 5.880 & 0.063 & 6.000 & $\cdots$ & 0.530 & 0.190 & 3 & 25.800 & $\cdots$ & 0.340 \\
\hline & 0.250 & $2003 A$ & 7.000 & 0.063 & 6.000 & $\cdots$ & 0.542 & 0.209 & 5 & 78.540 & $\cdots$ & 0.240 \\
\hline & & 2003B & 7.100 & 0.063 & 6.000 & $\cdots$ & 0.522 & 0.296 & 4 & 70.880 & $\cdots$ & $\cdots$ \\
\hline & 0.300 & P16C & 6.630 & 0.063 & 6.000 & $\cdots$ & 0.600 & 0.695 & 1 & 20.620 & $\cdots$ & 2.030 \\
\hline & & P16E & 6.780 & 0.063 & 6.000 & $\cdots$ & 0.620 & 0.920 & 1 & 28.270 & $\cdots$ & 1.960 \\
\hline
\end{tabular}

Table 3.10 Dual-Wa11 Structure: With and without MLI, S>4 inches 


\begin{tabular}{|c|c|c|c|c|c|c|c|c|c|c|c|c|c|c|c|c|}
\hline \multirow[b]{2}{*}{$\begin{array}{l}\text { IMPACT } \\
\text { ANGLE } \\
\text { (DEG) }\end{array}$} & \multirow[b]{2}{*}{$\begin{array}{l}\text { PROJECTILE } \\
\text { DI AME IER } \\
\text { (IN) }\end{array}$} & \multirow[b]{2}{*}{$\begin{array}{c}\text { TEST } \\
\text { NUMBER }\end{array}$} & \multirow[b]{2}{*}{$\begin{array}{l}\text { IMPACT } \\
\text { VELOCITY } \\
\text { (KM/SEC) }\end{array}$} & \multirow[b]{2}{*}{$\begin{array}{c}\text { SHIELD } \\
\text { THICKNESS }\end{array}$} & \multirow[b]{2}{*}{$\begin{array}{l}\text { MIN BUMPER } \\
\text { HOLE DIA. } \\
\text { (IN) }\end{array}$} & \multirow[b]{2}{*}{$\begin{array}{l}\text { MAX BUMPER } \\
\text { HOLE DIA. } \\
\text { (IN) }\end{array}$} & \multirow[b]{2}{*}{$\begin{array}{l}\text { PRESSURE WALL } \\
\text { HOLE DIAMETER } \\
\text { (IN) }\end{array}$} & \multirow[b]{2}{*}{$\begin{array}{l}\text { MUMBER OF } \\
\text { HOLES }\end{array}$} & \multirow[b]{2}{*}{$\begin{array}{l}\text { NORMAL - } \\
\text { DAMAGE } \\
\text { AREA } \\
\text { (SQ.IN.) }\end{array}$} & \multirow[b]{2}{*}{$\begin{array}{l}\text { MAXIMUM } \\
\text { PETAL LENGTH } \\
\text { (IN) }\end{array}$} & \multirow[b]{2}{*}{$\begin{array}{l}\text { SPALL } \\
\text { AREA } \\
\text { (SQ.IN.) }\end{array}$} & \multirow[b]{2}{*}{$\begin{array}{l}\text { PRESSURE WALL } \\
\text { HOLE DIAMETER } \\
\text { (IN) }\end{array}$} & \multirow[b]{2}{*}{$\begin{array}{l}\text { NUMBER OF } \\
\text { HOL.ES }\end{array}$} & \multirow[b]{2}{*}{$\begin{array}{l}\text { OBLIQUUE } \\
\text { DAMAGE } \\
\text { AREA } \\
\text { (SQ.IN.) }\end{array}$} & \multirow[b]{2}{*}{$\begin{array}{l}\text { MAXIMUM } \\
\text { PETAL LENGTH } \\
\text { (IN) }\end{array}$} & \multirow[b]{2}{*}{$\begin{array}{l}\text { SPALL } \\
\text { AREA } \\
\text { (SQ.IN.) }\end{array}$} \\
\hline & & & & & & & & & & & & & & & & \\
\hline \multirow[t]{2}{*}{0.000} & 0.187 & $101 \mathrm{~A}$ & 3.700 & 0.080 & 0.370 & 0.370 & 0.171 & 2 & 3.970 & $\ldots$ & -.. & $\cdots$ & - & $\cdots$ & $\cdots$ & $\cdots$ \\
\hline & & 1098 & 3.610 & 0.080 & 0.400 & 0.400 & $\cdots$ & -.. & 9.620 & $\cdots$ & $\cdots$ & $\cdots$ &.- & $\cdots$ & -. & $\cdots$ \\
\hline \multirow[t]{2}{*}{0.000} & 0.187 & $101 \mathrm{~B}$ & 4.260 & 0.080 & 0.560 & 0.560 & $\cdots$ & $\cdots$ & 12.560 & $\cdots$ & $\cdots$ & $\cdots$ & $\cdots$ & -. & - - & $\cdots$ \\
\hline & & $109 \mathrm{~A}$ & 4.060 & 0.080 & 0.429 & 0.429 & $\cdots$ & -- & 13.850 & $\cdots$ & $\cdots$ & $\cdots$ & $\cdots$ & $\cdots$ & $\cdots$ & $\cdots$ \\
\hline \multirow[t]{2}{*}{0.000} & 0.250 & P03 & 4.900 & 0.063 & 0.491 & 0.491 & 0.358 & 1 & 12.560 & -. & 0.530 & -. & -. & $\cdots$ & - - & $\cdots$ \\
\hline & & P04 & 4.950 & 0.063 & 0.491 & 0.491 & 0.304 & 1 & 10.010 & $\cdots$ & 0.310 & $\cdots$ & $\cdots$ & $\cdots$ & $\cdots$ & $\cdots$ \\
\hline \multirow[t]{2}{*}{0.000} & 0.250 & P05 & 6.900 & 0.063 & 0.560 & 0.560 & 0.185 & 1 & 14.190 & $\cdots$ & 0.030 & $\cdots$ & $\cdots$ & -. & $\cdots$ & $\cdots$ \\
\hline & & P06A & 6.950 & 0.063 & 0.572 & 0.572 & $\cdots$ & $\cdots$ & 19.640 & $\cdots$ & 0.720 & $\cdots$ & $\cdots$ & $\cdots$ & $\cdots$ & $\cdots$ \\
\hline \multirow[t]{2}{*}{0.000} & 0.313 & PI8A & 4.350 & 0.063 & 0.490 & 0.490 & 1.850 & 1 & 12.620 & $\cdots$ & 0.960 & $\cdots$ & $\cdots$ & -. & $\cdots$ & $\cdots$ \\
\hline & & PI8B & 4.370 & 0.063 & 0.500 & 0.500 & 1.470 & 2 & 13.210 & -- & 0.220 & $\cdots$ & $\cdots$ & $\cdots$ & $\cdots$ & $\cdots$ \\
\hline \multirow{2}{*}{0.000} & 0.313 & EH3A & 6.640 & 0.063 & 0.611 & 0.611 & 1.960 & 2 & 31.960 & $\cdots$ & 1.110 & $\cdots$ & -. & -. & $\ldots$ & - . \\
\hline & & EHSS6C & 6.690 & 0.063 & 0.622 & 0.622 & 1.260 & 1 & 19.630 & $\cdots$ & 0.840 & $\cdots$ & $\cdots$ & $\cdots$ & $\cdots$ & - - \\
\hline \multirow[t]{2}{*}{0.000} & 0.313 & EHSS6B & 6.630 & 0.063 & 0.578 & 0.578 & 2.230 & 7 & 16.800 & $\cdots$ & 0.050 & $\cdots$ & -.. & $\cdots$ & $\cdots$ & $\cdots-$ \\
\hline & & EHSSGA & 6.550 & 0.063 & 0.644 & 0.644 & 1.120 & 1 & 13.360 & $\cdots$ & 1.020 & $\cdots$ & $\cdots$ & $\cdots$ & $\cdots$ & $\cdots$ \\
\hline \multirow[t]{2}{*}{30.000} & 0.250 & EHSS3C & 6.810 & 0.063 & 0.491 & 0.542 & 0.790 & 1 & 10.320 & $\cdots$ & $\cdots$ & $\cdots$ & -. &.- & $\cdots$ & $\cdots$ \\
\hline & & $135 D$ & 6.850 & 0.063 & 0.521 & 0.561 & 0.957 & 1 & 15.210 & $\cdots$ & $\cdots$ & $\cdots$ & $\cdots$ & $\cdots$ & $\cdots$ & $\cdots$ \\
\hline \multirow[t]{2}{*}{45.000} & 0.250 & EHSS4A & 6.780 & 0.063 & 0.573 & 0.747 & $\cdots$ & $\cdots$ & 2.410 & $\cdots$ & $\because \cdot$ & 0.330 & 2 & 1.480 & $\cdots$ & $\cdots$ \\
\hline & & EHSS4B & 6.970 & 0.063 & 0.563 & 0.697 & 0.155 & 1 & 3.140 & $\cdots$ & $\cdots$ & 0.510 & 4 & 5.410 & $\cdots$ & $\cdots$ \\
\hline \multirow[t]{2}{*}{45.000} & 0.313 & EHRP3 & 6.830 & 0.063 & 0.625 & 0.781 & $\cdots$ & $\cdots$ & 6.490 & $\ldots$ & $\cdots$ & 1.010 & 3 & 7.070 & $\cdots$ & - - \\
\hline & & EHSS7A & 6.630 & 0.063 & 0.656 & 0.822 & $\cdots$ & $\cdots$ & 3.140 & $\cdots$ & $\cdots$ & 0.900 & 4 & 3.550 & $\cdots$ & $\cdots$ \\
\hline \multirow[t]{2}{*}{65.000} & 0.187 & EHRPQ & 7.320 & 0.063 & 0.472 & 0.669 & $\cdots$ & $\cdots$ & 15.710 & $\cdots$ & $\cdots$ & -- & -- & $\cdots$ & $\cdots$ & -. \\
\hline & & $156 \mathrm{~A}$ & 7.120 & 0.063 & 0.537 & 0.680 & $\ldots$ & $\cdots$ & 3.800 & $\cdots$ & $\cdots$ & $\cdots$ & $\cdots$ & $\cdots$ & $\cdots$ & $\cdots$ \\
\hline
\end{tabular}

Table 3.11 Dual-Wall Structures, Without MLI, Normal and Oblique Impact, $S=4$ inches 


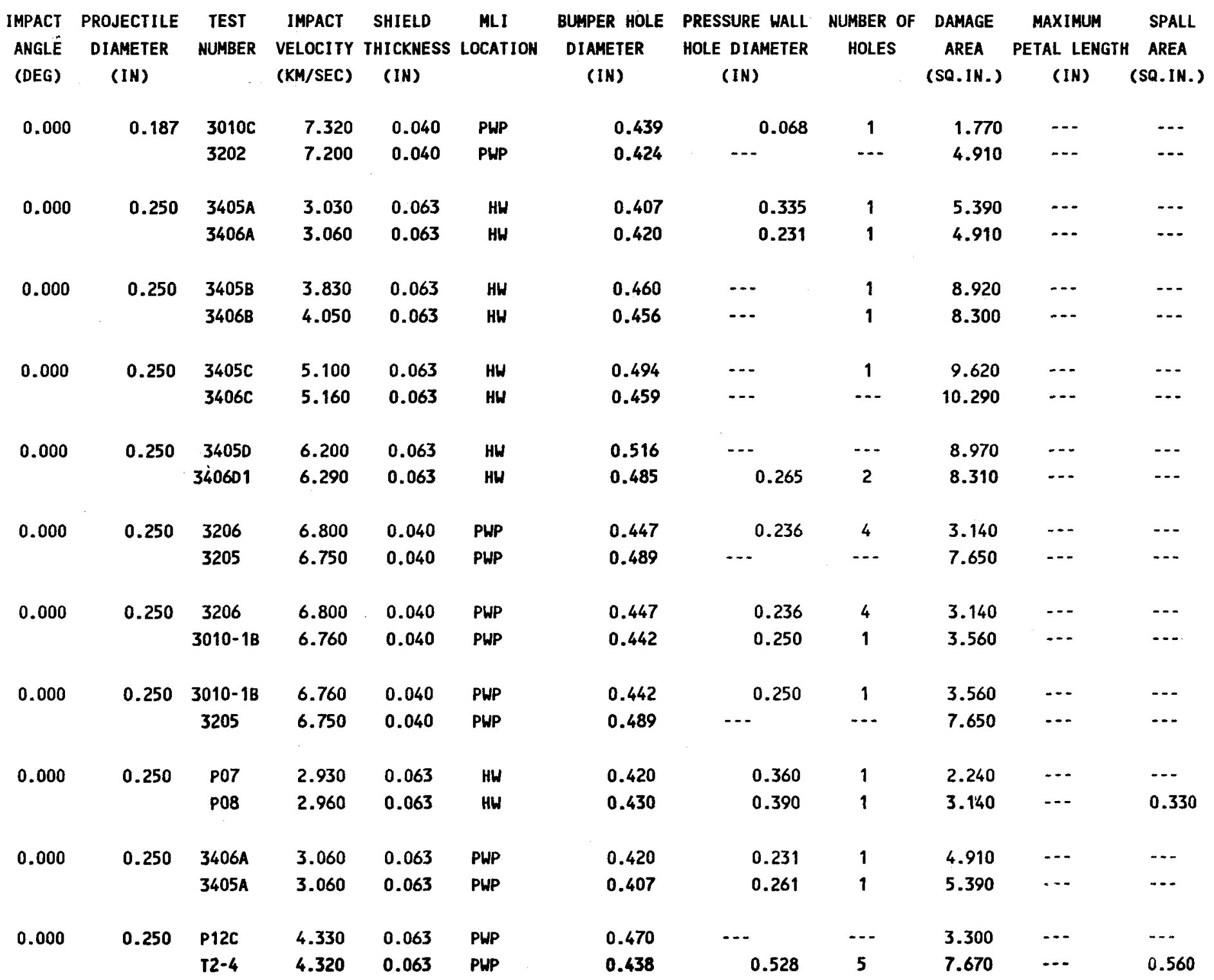

Table 3.12 Dual-Wa11 Structures, With MLI, Normal Impact, S-4 inches 


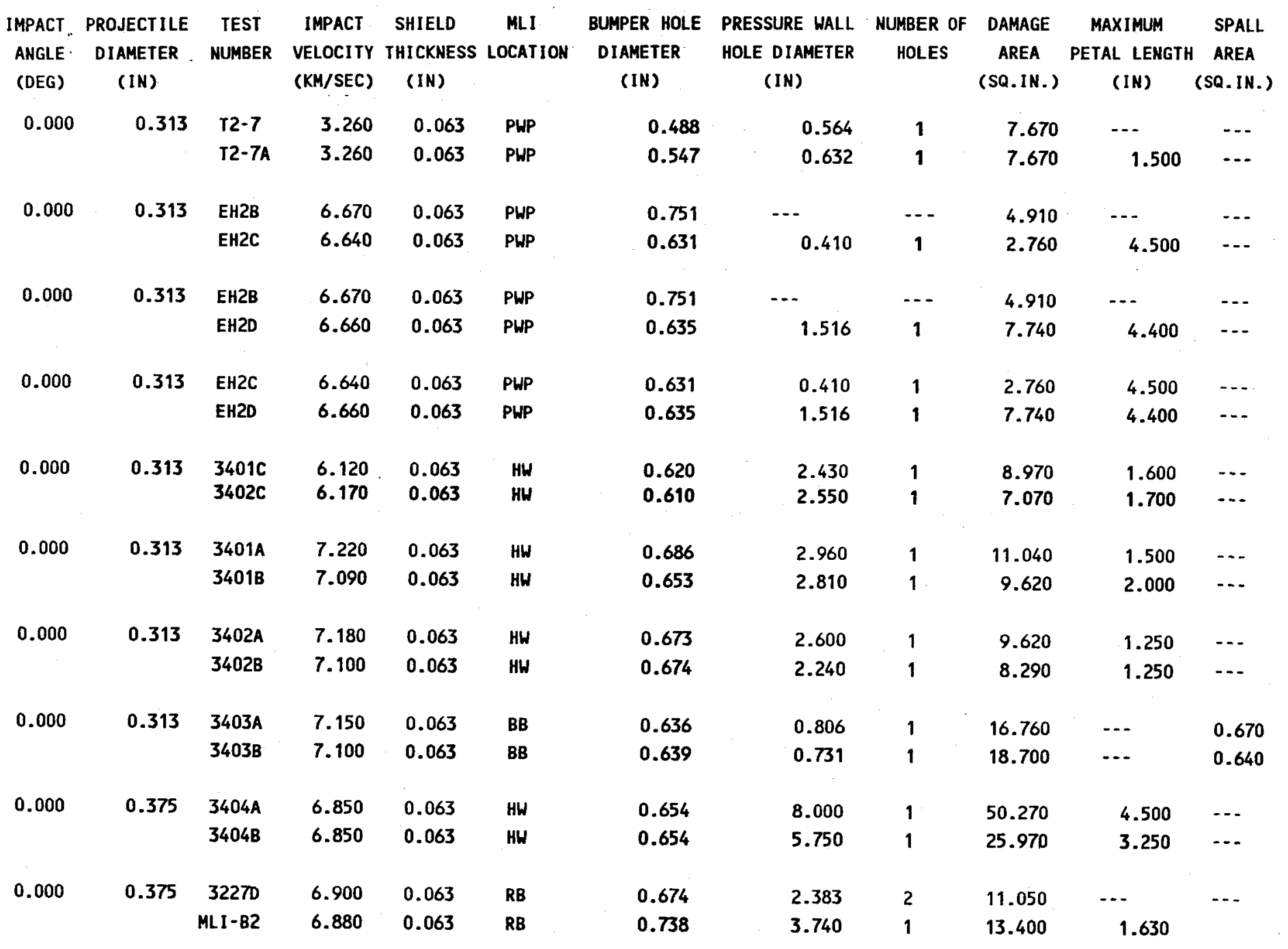

Table 3.12 Continued 


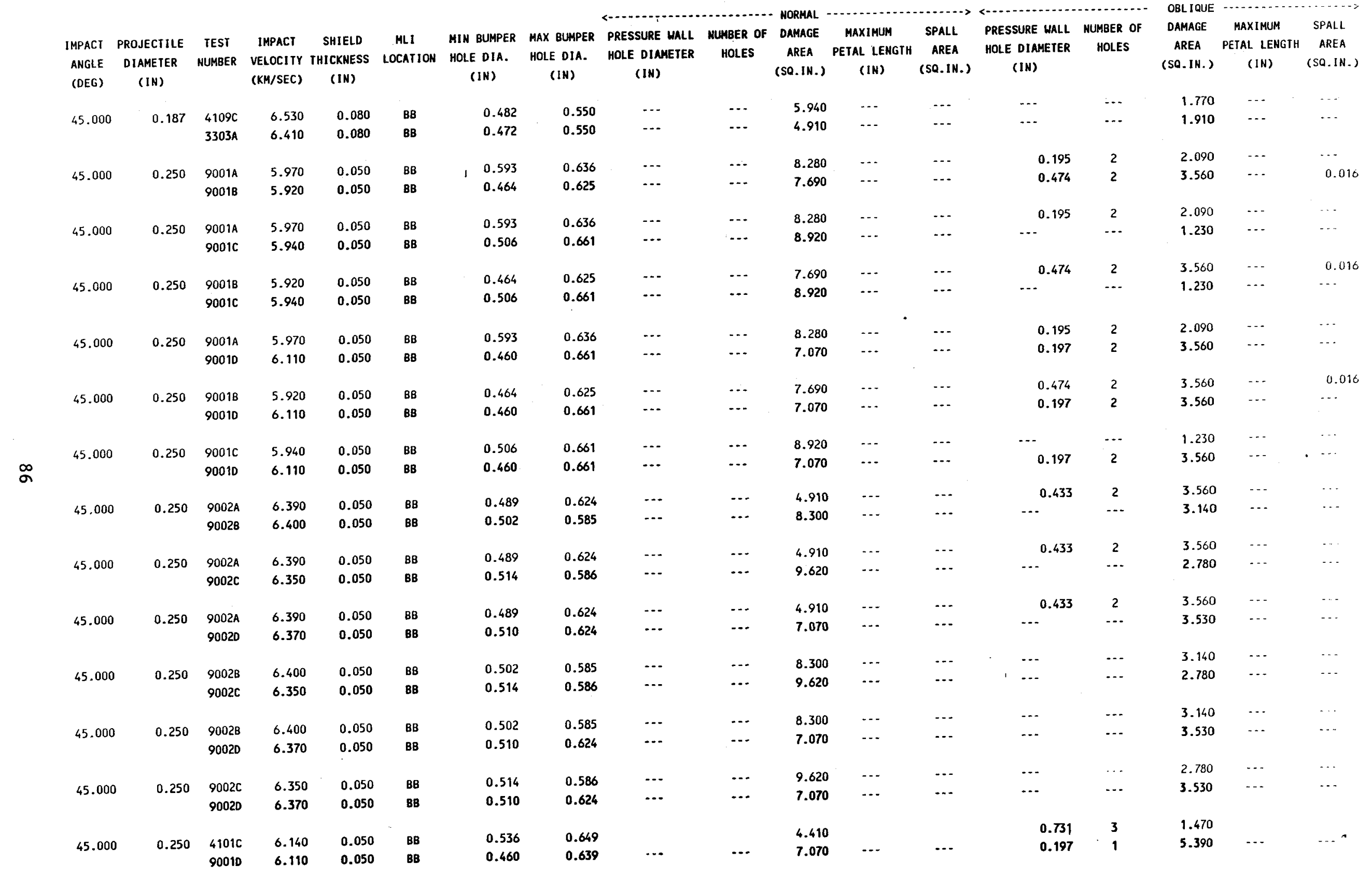




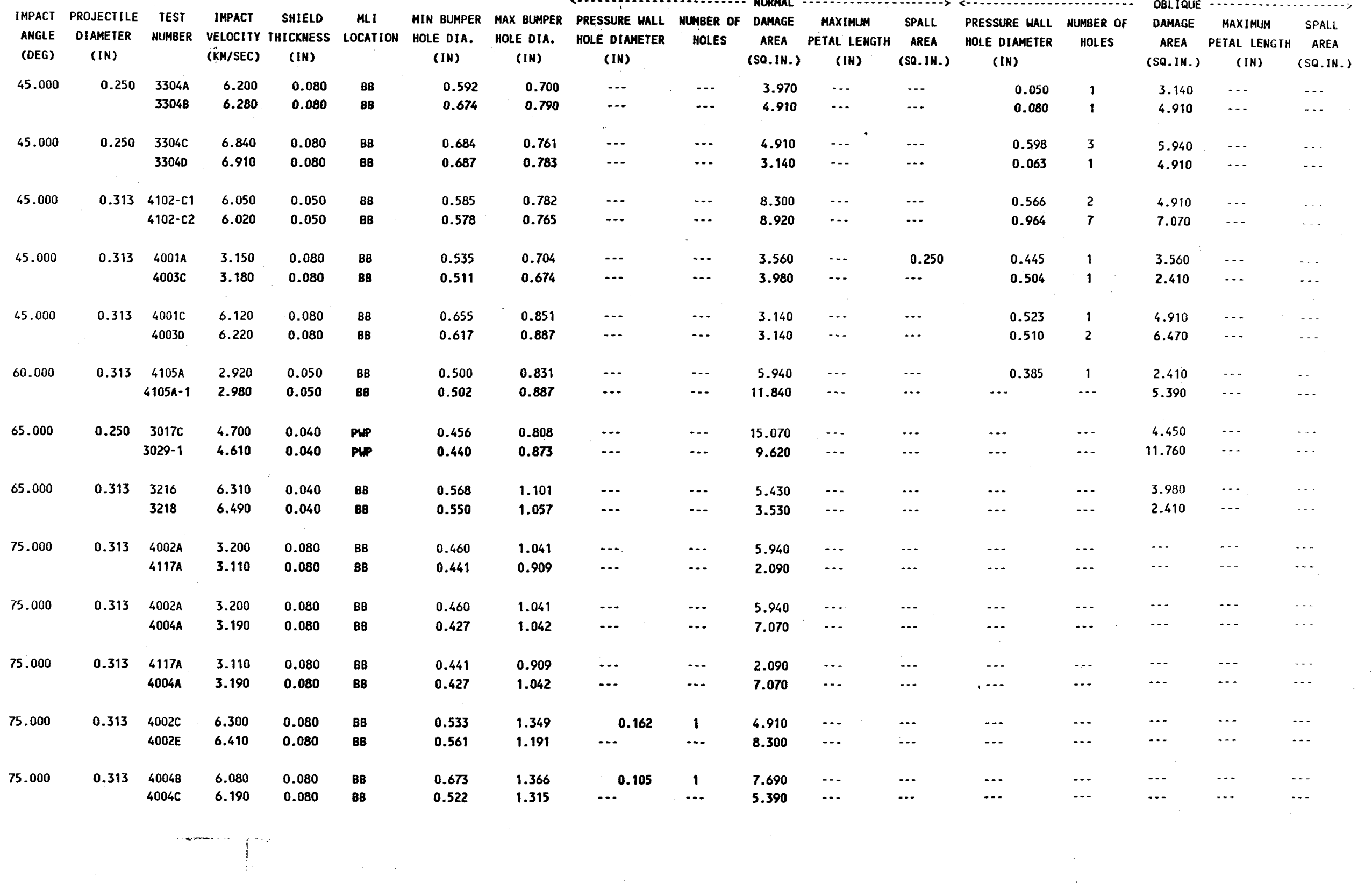

Table 3.13 Continued 


\subsection{CONCLUSIONS AND RECOMMENDATIONS}

\subsection{Summary and Conclusions}

Phenomena repeatability and data uncertainty analyses were performed using the NASA/MSFC Phase B and Phase C/D hypervelocity impact test data was performed. The information used consisted of the 540 Phase B tests in the Hypervelocity Impact Damage Database developed under a previous effort and a supplemental database of 410 Phase C/D tests. The analyses-sought to quantify the repeatability of the phenomena ocurring in dual-wall structures under hypervelocity impact based on the testing performed at the NASA/MSFC light gas gun during the time period 1985-1991 and to determine the uncertainty of the measurements taken from damaged test specimens.

The results of the phenomena repeatability analysis show that if 3 identical dual-wall structures were to be tested using the NASA/MSFC light gas gun under similar impact conditions, then it is entirely likely that either the pressure walls in 2 of these 3 tests will be perforated and 1 will not or the pressure walls in 2 of these tests will not be perforated and 1 will. The results obtained also show that the repeatability of rearside spallation (or the lack thereof) in such dual-wall structures is considerably higher: of 10 tests performed, it is highly likely that 9 of them will all either show some sort of rear-side spallation and 1 will not or 9 of them will all either not be spalled and 1 of them will. The results of the uncertainty analysis show that the level of uncertainty in the response data can vary significantly depending on the response considered. However, the observations made in the uncertainty analysis in general reinforce those made during the repeatability analysis. 


\subsection{Recommendations}

An extensive program of spacecraft materials testing and evaluation under hypervelocity projectile impact has been underway at NASA/MSFC since its inception over almost three decades ago. While an extensive test database has been established, it is evident that further testing is still required to fully understand the phenomena associated with hypervetecity impact and for a more comprehensive hypervelocity impact test datat..e. Additional data will also allow the calculation of Repeatability Indices for test groups for which at present it is not possible. The following recommendations are made for a future high speed impact test program to address current needs.

1) Perform additional testing at higher impact velocities. While an impact velocity of $7 \mathrm{~km} / \mathrm{sec}$ is near the upper limit of the velocities attainable by the light gas gun, it is clear that more testing must be performed at these high velocities in order to be able to even come close to duplicating the anticipated on-orbit impact velocities.

2) Perform additional testing using larger projectiles. Although impacts by smaller pieces of orbital debris are more probable than impacts by excessively large pieces, the effects of large particle impact must be fully understood in order to decide whether or not such impacts can be withstood by existing or newly-developed protective measures.

3) Perform additional testing at higher impact obliquities. With the increasing concern for the pollution of the orbital environment by the secondary ricochet debris particles that are formed in an oblique hypervelocity impact, additional oblique impact testing is necessary, especially in the high obliquity regime (ie. obliquities greater than $60^{\circ}$ ) to fully understand the damage potential of these secondary debris particles. 
4) Perform additional testing of alternate bumper plate materials and alternate wall configurations. With the recent development of many new high-strength materials, it is imperative that additional testing be performed with bumper plates made from materials other than aluminum. Additionally, alternative configurations, such as double or triple bumpers at stand-off distances other than $10 \mathrm{~cm}$, should be test with bumper plates made from these new materials.

5) Perform additional tests using non-spherical projectiles. While this has been done mainly for reasons of consistency and repeatability, it is clear that orbital debris particles are not round, but are rather jagged with varying length-to-diameter ratios. Additional testing must be performed using non-spherical projectiles in order to be able to extrapolate the response of a structure under spherical projectile impact to a structure that is impacted by a non-spherical projectile.

6) Perform additional tests with different density projectiles. It has become evident that the original constant density approximation for orbital debris particles is inaccurate, especially for particles larger than $0.6 \mathrm{~cm}$ in diameter. While the testing to date has produced results that are certainly applicable to small particle impacts, whether or not they can be extended to large particle impact remains to be seen.

7) Perform tests to determine the effects of pressure wall curvature on module wall response. All the tests to date have been performed using flat bumper and pressure wall plates. Does the curvature of the module have an effect on the perforation resistance of a dual-wall structure? Additional testing must be performed with curved inner and outer walls to adequately address this issue. 
APPENDIX I - PHASE C/D TESTING PARAMETER DATABASE 


\begin{tabular}{|c|c|c|c|c|c|c|c|c|c|c|c|}
\hline SHOT NO. & TEST NO. & $\begin{array}{c}\text { BUMPER } \\
\text { MATERIAL }\end{array}$ & $\begin{array}{c}\text { BUMPER } \\
\text { THICKNESS } \\
\text { (IN) }\end{array}$ & $\begin{array}{l}\text { BUMPER } \\
\text { STANDOFF } \\
\text { (IN) }\end{array}$ & $\begin{array}{c}M L I \\
(Y / N)\end{array}$ & $\begin{array}{l}\text { BACK WALL } \\
\text { MATERIAL. }\end{array}$ & $\begin{array}{c}\text { BACK WALL } \\
\text { THICKNESS } \\
\text { (IN) }\end{array}$ & $\begin{array}{c}\text { PROJECTILE } \\
\text { MATERIAL }\end{array}$ & $\begin{array}{l}\text { PROJECTILE } \\
\text { DIAMETER } \\
\text { (IN) }\end{array}$ & $\begin{array}{r}\text { IMPACT } \\
\text { ANGLE } \\
\text { (DEG) }\end{array}$ & $\begin{array}{c}\text { AVERAGE } \\
\text { VELOCITY } \\
\text { (KM/S) }\end{array}$ \\
\hline 960 & 2001-A & $6061-16$ & 0.063 & 6 & NO & 2219-โ 87 & 0.125 & $A L-1100$ & 0.187 & 0 & 3.77 \\
\hline 962 & $2001-8$ & $6061-16$ & 0.063 & 6 & NO & 2219-T87 & 0.125 & $A L-1100$ & 0.187 & 0 & 3.93 \\
\hline 961 & $2001-C$ & $6061-\mathrm{T} 6$ & 0.063 & 6 & NO & 2219-T87 & 0.125 & $A L=1100$ & 0.187 & 0 & 4.05 \\
\hline 929 & 2002-A & $6061-T 6$ & 0.063 & 6 & NO & 2219-T87 & 0.125 & $A L-1100$ & 0.250 & 0 & 6.08 \\
\hline 930 & $2002-B$ & $6061-16$ & 0.063 & 6 & NO & 2219-T87 & 0.125 & $A L-1100$ & 0.250 & 0 & 6.50 \\
\hline 940 & $2002-C$ & $6061-T 6$ & 0.063 & 6 & NO & 2219-T87 & 0.125 & $A L-1100$ & 0.250 & 0 & 6.75 \\
\hline 949 & $2003-A$ & $6061-16$ & 0.063 & 6 & NO & $2219-\mathrm{T} 87$ & 0.125 & $A L-1100$ & 0.250 & 0 & 7.00 \\
\hline 944 & 2003-B & $6061-16$ & 0.063 & 6 & NO & 2219-T87 & 0.125 & $A L-1100$ & 0.250 & 0 & 7.10 \\
\hline 945 & 2003-C & $6061-T 6$ & 0.063 & 6 & NO & 2219-T87 & 0.125 & $A L-1100$ & 0.250 & 0 & 7.28 \\
\hline 959 & 2003-A1 & $6061-T 6$ & 0.063 & 6 & NO & 2219-T87 & 0.125 & $A L-1100$ & 0.250 & 0 & 5.98 \\
\hline 956 & 2003-B1 & $6061-T 6$ & 0.063 & 6 & NO & 2219-T87 & 0.125 & $A L-1100$ & 0.250 & 0 & 6.58 \\
\hline 941 & 2004-A & $6061-T 6$ & 0.063 & 4 & NO & $2219-T 87$ & 0.125 & $A L-1100$ & 0.250 & 0 & 7.20 \\
\hline 939 & $2004-B$ & $6061-16$ & 0.063 & 4 & NO & $2219-187$ & 0.125 & $A L-1100$ & 0.250 & 0 & 6.92 \\
\hline 931 & $2004-C$ & 6061-T6 & 0.063 & 4 & NO & 2219-T87 & 0.125 & AL -1100 & 0.250 & 0 & 5.95 \\
\hline
\end{tabular}

P2000SER. WK1 
BUMPER

SHOT NO. TEST NO. MATERIAL
BUMPER BUMPER THICXNESS STANDOF

(IN) (IN)

MLI $(Y / N)$ MATERIAL

BACKWALL PROJECTILE PROJECTILE THICKNESS MATERIAL DIAMETER

(IN)

AVACT AVRAGE

GLE VELOCITY

$\begin{array}{lccll}965 & 3001 & 6061-T 6 & 0.040 & 4 \\ 798 & 3001-A & 6061-T 6 & 0.032 & 4 \\ 799 & 3001-B & 6061-T 6 & 0.032 & 4 \\ 800 & 3001-\mathrm{C} & 6061-T 6 & 0.032 & 4 \\ 801 & 3001-\mathrm{D} & 6061-\mathrm{T} 6 & 0.032 & 4 \\ 802 & 3001-\mathrm{E} & 6061-\mathrm{T} 6 & 0.032 & 4 \\ 803 & 3002-\mathrm{A} & 6061-\mathrm{T} 6 & 0.032 & 4 \\ 804 & 3002-\mathrm{B} & 6061-\mathrm{T} 6 & 0.032 & 4 \\ 806 & 3002-\mathrm{C} & 6061-\mathrm{T} 6 & 0.032 & 4 \\ 963 & 3003 & 6061-\mathrm{T} 6 & 0.032 & 4 \\ 964 & 3004 & 6061-\mathrm{T} 6 & 0.032 & 4 \\ 807 & 3004-\mathrm{A} & 6061-\mathrm{T} 6 & 0.032 & 4 \\ 810 & 3004-\mathrm{B} & 6061-\mathrm{T} 6 & 0.032 & 4 \\ 808 & 3005-\mathrm{A} & 6061-\mathrm{T} 6 & 0.032 & 4 \\ 811 & 3005-\mathrm{B} & 6061-\mathrm{T} 6 & 0.032 & 4 \\ 812 & 3006-\mathrm{A} & 6061-\mathrm{T} 6 & 0.032 & 4 \\ 818 & 3007-\mathrm{A} & 6061-\mathrm{T} 6 & 0.032 & 4 \\ 819 & 3007-\mathrm{B} & 6061-\mathrm{T} 6 & 0.032 & 4 \\ 820 & 3007-\mathrm{C} & 6061-\mathrm{T} 6 & 0.032 & 4 \\ 821 & 3008-\mathrm{A} & 6061-\mathrm{T} 6 & 0.032 & 4 \\ 822 & 3008-\mathrm{B} & 6061-\mathrm{T} 6 & 0.032 & 4 \\ 823 & 3009-\mathrm{A} & 6061-\mathrm{T} 6 & 0.032 & 4 \\ 824 & 3009-\mathrm{B} & 6061-\mathrm{T} 6 & 0.032 & 4 \\ 813 & 3010-\mathrm{A} & 6061-\mathrm{T} 6 & 0.040 & 4 \\ 814 & 3010-\mathrm{B} & 6061-\mathrm{T} 6 & 0.040 & 4 \\ 815 & 3010-\mathrm{C} & 6061-\mathrm{T} 6 & 0.040 & 4 \\ 816 & 3010-1-\mathrm{A} & 6061-\mathrm{T} 6 & 0.040 & 4 \\ 817 & 3010-1-\mathrm{B} & 6061-\mathrm{T} 6 & 0.040 & 4 \\ 826 & 3011-\mathrm{A} & 6061-\mathrm{T} 6 & 0.040 & 4 \\ 825 & 3011-\mathrm{B} & 6061-\mathrm{T} 6 & 0.040 & 4 \\ 827 & 3012-\mathrm{B} & 6061-\mathrm{T} 6 & 0.040 & 4 \\ 828 & 3012-\mathrm{D} & 6061-\mathrm{T} 6 & 0.040 & 4 \\ 830 & 3013-\mathrm{A} & 6061-\mathrm{T} 6 & 0.040 & 4 \\ 831 & 3017-\mathrm{A} & 6061-\mathrm{T} 6 & 0.040 & 4 \\ 832 & 3017-\mathrm{B} & 6061-\mathrm{T} 6 & 0.040 & 4\end{array}$

\begin{tabular}{|c|c|c|c|c|c|c|}
\hline YES & 2219-T87 & 0.125 & AL- 1100 & 0.187 & 0 & 6.63 \\
\hline YES & 2219-T87 & 0.125 & $A L-1100$ & 0.187 & 0 & 3.90 \\
\hline YES & 2219-T87 & 0.125 & $A L-1100$ & 0.187 & 0 & 5.76 \\
\hline YES & 2219-T87 & 0.125 & $A L-1100$ & 0.187 & 0 & 6.22 \\
\hline YES & $2219-T 87$ & 0.125 & $A L-1100$ & 0.187 & 0 & 7.19 \\
\hline YES & 2219-T87 & 0.125 & $A L-1100$ & 0.187 & 0 & 6.76 \\
\hline YES & 2219-T87 & 0.125 & $A L-1100$ & 0.250 & 0 & 6.99 \\
\hline YES & 2219-T87 & 0.125 & $A L=1100$ & 0.250 & 0 & 7.33 \\
\hline YES & 2219-T87 & 0.125 & $A L-1100$ & 0.250 & D & 7.52 \\
\hline YES & $2219-T 87$ & 0.125 & $A L-1100$ & 0.187 & 45 & 6.10 \\
\hline YES & 2219-T87 & 0.125 & $A L-1100$ & 0.187 & 45 & 7.70 \\
\hline YES & 2219-T87 & 0.125 & $A L-1100$ & 0.187 & 45 & 6.81 \\
\hline YES & 2219-T87 & 0.125 & $A L-1100$ & 0.187 & 45 & 6.57 \\
\hline YES & 2219-T87 & 0.125 & $A L-1100$ & 0.187 & 45 & 7.35 \\
\hline YES & 2219-T87 & 0.125 & $A L=1100$ & 0.250 & 45 & 7.60 \\
\hline YES & 2219-T87 & 0.125 & $A L-1100$ & 0.313 & 45 & 7.01 \\
\hline YES & $2219-T 87$ & 0.125 & $A L=1100$ & 0.187 & 65 & 6.53 \\
\hline YES & $2219-187$ & 0.125 & $A L-1100$ & 0.187 & 65 & 4.78 \\
\hline YES & 2219-T87 & 0.125 & $A L-1100$ & 0.187 & 65 & 3.35 \\
\hline YES & 2219-T87 & 0.125 & $A L-1100$ & 0.250 & 65 & 4.61 \\
\hline YES & $2219-\mathrm{T} 87$ & 0.125 & $A L-1100$ & 0.25 & 65 & 4.25 \\
\hline YES & 2219-T87 & 0.125 & $A L-1100$ & 0.313 & 65 & 5.12 \\
\hline YES & 2219-T87 & 0.125 & $A L-1100$ & 0.313 & 65 & 4.54 \\
\hline YES & 2219-T87 & 0.125 & $A L-1100$ & 0.313 & 0 & 5.86 \\
\hline YES & 2219-โ87 & 0.125 & $A L-1100$ & 0.187 & 0 & 6.82 \\
\hline YES & 2219-T87 & 0.125 & $A L-1100$ & 0.187 & 0 & 7.32 \\
\hline YES & 2219-T87 & 0.125 & $A L-1100$ & 0.250 & 0 & 7.22 \\
\hline YES & $2219-T 87$ & 0.125 & $A L-1100$ & 0.250 & 0 & 6.76 \\
\hline YES & $2219-T 87$ & 0.125 & $A L-1100$ & 0.313 & 0 & 7.02 \\
\hline YES & 2219-T87 & 0.125 & $A L-1100$ & 0.313 & 0 & 6.75 \\
\hline YES & 2219-T87 & 0.125 & $A L-1100$ & 0.313 & 30 & 2.67 \\
\hline YES & 2219-T87 & 0.125 & AL- 1100 & 0.187 & 30 & 4.31 \\
\hline YES & 2219-T87 & 0.125 & AL-1100 & 0.250 & 30 & 6.98 \\
\hline YES & 2219-T87 & 0.125 & $A L-1100$ & 0.250 & 65 & 6.97 \\
\hline YES & 2219-T87 & 0.125 & $A L-1100$ & 0.250 & 65 & 6.25 \\
\hline
\end{tabular}




\begin{tabular}{|c|c|c|c|c|c|c|c|c|c|c|c|}
\hline SHOT NO. & TEST NO. & $\begin{array}{c}\text { BUMPER } \\
\text { MATERIAL }\end{array}$ & $\begin{array}{l}\text { BUMPER } \\
\text { THICKNESS } \\
\text { (IN) }\end{array}$ & $\begin{array}{l}\text { BUMPER } \\
\text { STANDOFF } \\
\text { (IN) }\end{array}$ & $\begin{array}{c}M L I \\
(Y / N)\end{array}$ & $\begin{array}{l}\text { BACKHALL } \\
\text { MATERIAL }\end{array}$ & $\begin{array}{c}\text { BACKWALL } \\
\text { THICKNESS } \\
(1 N)\end{array}$ & $\begin{array}{l}\text { PROJECTILE } \\
\text { MATERIAL }\end{array}$ & $\begin{array}{l}\text { PROJECTILE } \\
\text { DIAMETER }\end{array}$ & $\begin{array}{r}\text { IMPACT } \\
\text { ANGLE } \\
\text { (DEG) }\end{array}$ & $\begin{array}{l}\text { AVERAC } \\
\text { VELOCI T } \\
(\mathrm{KM} / \mathrm{S})\end{array}$ \\
\hline 833 & $3017-c$ & $6061-16$ & 0.040 & 4 & YES & 2219-T87 & 0.125 & $A L-1100$ & 0.250 & 65 & 4.70 \\
\hline 876 & 3019-A & $6061-T 6$ & 0.032 & 4 & YES & 2219-T87 & 0.125 & $A L-1100$ & 0.187 & 0 & 4.25 \\
\hline 877 & 3019-8 & $6061-16$ & 0.032 & 4 & YES & 2219-T87 & 0.125 & $A L-1100$ & 0.187 & 0 & 4.76 \\
\hline 844 & $3020-A$ & $6061-T 6$ & 0.063 & 4 & YES & 2219-T87 & 0.125 & $A L-1100$ & 0.313 & 0 & 6.65 \\
\hline 834 & $3020-B$ & $6061-T 6$ & 0.063 & 4 & YES & 2219-T87 & 0.125 & $A L-1100$ & 0.313 & 0 & 7.05 \\
\hline 845 & 3021-A & $6061-16$ & 0.063 & 4 & YES & $2219-187$ & 0.125 & $A L-1100$ & 0.313 & 0 & 7.18 \\
\hline 836 & 3022-A & $6061-\mathrm{T} 6$ & 0.063 & 4 & YES & 2219-T87 & 0.125 & $A L-1100$ & 0.187 & 30 & 2.15 \\
\hline 835 & 3022-B & $6061-T 6$ & 0.063 & 4 & YES & $2219-T 87$ & 0.125 & $A L-1100$ & 0.187 & 30 & 3.25 \\
\hline 842 & $3022-c$ & $6061-16$ & 0.063 & 4 & YES & 2219-T87 & 0.125 & $A L=1100$ & 0.187 & 30 & 4.06 \\
\hline 843 & 3022-D & $6061-T 6$ & 0.063 & 4 & YES & 2219-T87 & 0.125 & $A L-1100$ & 0.187 & 30 & 4.86 \\
\hline 840 & 3023-A & $6061-T 6$ & 0.063 & 4 & YES & 2219-T87 & 0.125 & $A L-1100$ & 0.250 & 30 & 6.90 \\
\hline $\begin{array}{l}839 \\
841\end{array}$ & $\begin{array}{l}3023-B \\
3024-8\end{array}$ & $\begin{array}{l}6061-16 \\
6061-T 6\end{array}$ & $\begin{array}{l}0.063 \\
0.063\end{array}$ & $\begin{array}{l}4 \\
4\end{array}$ & $\begin{array}{l}\text { YES } \\
\text { YES }\end{array}$ & $\begin{array}{l}2219-T 87 \\
2219-T 87\end{array}$ & $\begin{array}{l}0.125 \\
0.125\end{array}$ & $\begin{array}{l}A L-1100 \\
A L-1100\end{array}$ & $\begin{array}{l}0.250 \\
0.313\end{array}$ & $\begin{array}{l}30 \\
30\end{array}$ & $\begin{array}{l}6.15 \\
7.02\end{array}$ \\
\hline 847 & 3027-A & $6061-16$ & 0.063 & 4 & YES & 2219-T87 & 0.125 & $A L-1100$ & 0.250 & 45 & 6.90 \\
\hline 846 & 3028-A & $6061-T 6$ & 0.063 & 4 & YES & $2219-\mathrm{T} 87$ & 0.125 & $A L-1100$ & 0.313 & 45 & 7.01 \\
\hline 848 & $3029-\mathrm{C}$ & $6061-T 6$ & 0.063 & 4 & YES & 2219-T87 & 0.125 & $A L-1100$ & 0.187 & 65 & 3.88 \\
\hline 849 & $3030-A$ & $6061-16$ & 0.063 & 4 & YES & 2219-T87 & 0.125 & $A L-1100$ & 0.187 & 65 & 3.49 \\
\hline 851 & $3031-B$ & $6061-T 6$ & 0.063 & 4 & YES & $2219-T 87$ & 0.125 & $A L-1100$ & 0.313 & 65 & 3.36 \\
\hline 850 & $3031-C$ & 6061-T6 & 0.063 & 4 & YES & $2219-T 87$ & 0.125 & $A L=1100$ & 0.313 & 65 & 6.99 \\
\hline 852 & $3033-A$ & $6061-T 6$ & 0.080 & 4 & YES & $2219-T 87$ & 0.125 & $A L-1100$ & 0.250 & 0 & 3.86 \\
\hline 853 & 3033-B & $6061-T 6$ & 0.080 & 4 & YES & $2219-187$ & 0.125 & $A L-1100$ & 0.250 & 0 & 3.40 \\
\hline 869 & $3033-c$ & $6061-T 6$ & 0.080 & 4 & YES & 2219-T87 & 0.125 & $A L-1100$ & 0.250 & 0 & 5.57 \\
\hline 854 & 3034-A & $6061-T 6$ & 0.080 & 4 & YES & 2219-โ87 & 0.125 & $A L-1100$ & 0.313 & 0 & 4.50 \\
\hline 855 & $3034-B$ & 6061-T6 & 0.080 & 4 & YES & 2219-T87 & 0.125 & $A L-1100$ & 0.313 & 0 & 3.63 \\
\hline 856 & 3034-C & $6061-16$ & 0.080 & 4 & YES & 2219-T87 & 0.125 & $A L-1100$ & 0.313 & 0 & 5.60 \\
\hline 863 & $3035-A$ & $6061-T 6$ & 0.080 & 4 & YES & 2219-T87 & 0.125 & $A L-1100$ & 0.313 & 45 & 5.28 \\
\hline 864 & 3035-B & 6061-T6 & 0.080 & 4 & YES & 2219-T87 & 0.125 & $A L-1100$ & 0.313 & 45 & 5.90 \\
\hline 857 & 3036-A & $6061-T 6$ & 0.080 & 4 & YES & 2219-T87 & 0.125 & $A L-1100$ & 0.250 & 45 & 5.53 \\
\hline 858 & 3036-B & $6061-T 6$ & 0.080 & 4 & YES & 2219-T87 & 0.125 & $A L-1100$ & 0.250 & 45 & 6.44 \\
\hline 861 & 3037-A & $6061-16$ & 0.080 & 4 & YES & $2219-T 87$ & 0.125 & $A L-1100$ & 0.313 & 45 & 7.12 \\
\hline $\begin{array}{l}870 \\
871\end{array}$ & $\begin{array}{l}3038-A \\
3038-B\end{array}$ & $\begin{array}{l}6061-T 6 \\
6061-16\end{array}$ & $\begin{array}{l}0.080 \\
0.080\end{array}$ & $\begin{array}{l}4 \\
4\end{array}$ & $\begin{array}{l}\text { YES } \\
\text { YES }\end{array}$ & $\begin{array}{l}2219-T 87 \\
2219-T 87\end{array}$ & $\begin{array}{l}0.125 \\
0.125\end{array}$ & $\begin{array}{l}A L-1100 \\
A L-1100\end{array}$ & $\begin{array}{l}0.187 \\
0.187\end{array}$ & $\begin{array}{l}65 \\
65\end{array}$ & $\begin{array}{l}5.01 \\
6.38\end{array}$ \\
\hline 866 & $3039-A$ & $6061-T 6$ & 0.080 & 4 & YES & 2219-T87 & 0.125 & $A L-1100$ & 0.250 & 65 & 5.66 \\
\hline 867 & $3039-B$ & $6061-T 6$ & 0.080 & 4 & YES & 2219-T87 & 0.125 & $A L-1100$ & 0.250 & 65 & 4.54 \\
\hline 868 & $3039-C$ & $6061-T 6$ & 0.080 & 4 & YES & $2219-T 87$ & 0.125 & $A L-1100$ & 0.250 & 65 & 6.26 \\
\hline 865 & 3040-A & 6061-T6 & 0.080 & 4 & YES & 2219-T87 & 0.125 & $A L-1100$ & 0.313 & 65 & 6.92 \\
\hline
\end{tabular}

P3000SER. WK1 (Continued) 
BUMPER BUMPER BUMPER SHOT NO. TEST NO. MATERIAL THICKNESS STANDOFF (IN) (IN)

$3120-8 \quad 6061-16 \quad 0.032$

$3121-A \quad 6061-16 \quad 0.032$

$\begin{array}{lll}3121-\mathrm{B} & 6061-16 & 0.032\end{array}$

3122-B $6061-16 \quad 0.032$

3122-C $6061-16 \quad 0.032$
MLI BaCKHALl BACKHALL PROJECTILE PROJECIIL IMPACt AVERAGE (Y/N)

MATERIAL THICKNE

$$
\text { (IN) }
$$

YES/0.25" O.B. 2219-187

YES/0.25" O.B. 2219-T87

YES/0.25" 0.8. 2219-187

YES/0.25" O.B. 2219-187

YES/0.25" 0.B. 2219-T87

YES/0.25" 0.8. 2219-187

YES/0.25" 0.8. 2219-T87

YES/0.25" 0.8. 2219- T87

YES/0.25" 0.B. 2219-T87

YES/0.25" O.B. 2219-T87

YES/0.25" 0.B. 2219-187

YES/0.25" 0.8. 2219-187

YES/0.25" 0.8. 2219- 887

YES/0.25" O.B. 2219-I87

3122-A 6061-16 0.032

3122-D 6061-16 $\quad 0.032$

3123-A 6061-16 0.032

3123-B $6061-16 \quad 0.032$

3124-A 6061-T6 0.032

3124-B 6061-16 0.032

3124-C $6061-16 \quad 0.032$

3128-A 6061-16 0.063

312B-B 6061-T6 0.063

3129-A 6061-16 $\quad 0.063$

3129-B 6061-T6 $\quad 0.063$

3130-A 6061-16 0.063

$\begin{array}{lll}3130-A & 6061-16 & 0.063 \\ 3131-A & 6061-16 & 0.063\end{array}$

3131-B 6061-T6 0.063

3131-C $6061-16 \quad 0.063$

3132-A 6061-T6 0.063

3132-B 6061-16 $\quad 0.063$

3132-C 6061-T6 0.063

3133-A 6061-T6 0.063

3133-B 6061-16 $\quad 0.063$

3133-C $6061-16 \quad 0.063$

3133-D 6061-16 $\quad 0.063$

$\begin{array}{lllll}0.188 & \text { AL-1100 } & 0.187 & 0 & 3.82 \\ 0.188 & \text { AL-1100 } & 0.187 & 0 & 4.32 \\ 0.188 & \text { AL-1100 } & 0.187 & 0 & 3.51 \\ 0.188 & \text { AL-1100 } & 0.250 & 0 & 3.77 \\ 0.188 & \text { AL-1100 } & 0.250 & 0 & 4.65 \\ 0.188 & \text { AL-1100 } & 0.250 & 0 & 5.25 \\ 0.188 & \text { AL-1100 } & 0.250 & 0 & 4.84 \\ 0.188 & \text { AL-1100 } & 0.250 & 0 & 5.14 \\ 0.188 & \text { AL-1100 } & 0.313 & 0 & 5.93 \\ 0.188 & \text { AL-1100 } & 0.313 & 0 & 5.79 \\ 0.188 & \text { AL-1100 } & 0.313 & 0 & 6.37 \\ 0.188 & \text { AL-1100 } & 0.313 & 0 & 6.5 \\ 0.188 & \text { AL-1100 } & 0.313 & 0 & 6.75 \\ 0.188 & \text { AL-1100 } & 0.250 & 45 & 4.87 \\ 0.188 & \text { AL-1100 } & 0.250 & 45 & 4.43 \\ 0.125 & \text { AL-1100 } & 0.250 & 0 & 4.95 \\ 0.125 & \text { AL-1100 } & 0.250 & 0 & 5.42 \\ 0.125 & \text { AL-1100 } & 0.313 & 0 & 5.6 \\ 0.125 & \text { AL-1100 } & 0.313 & 0 & 4.64 \\ 0.125 & \text { AL-1100 } & 0.187 & 45 & 7.41 \\ 0.125 & \text { AL-1100 } & 0.187 & 45 & 6.27 \\ 0.125 & \text { AL-1100 } & 0.187 & 45 & 4.93 \\ 0.125 & \text { AL-1100 } & 0.187 & 45 & 5.42 \\ 0.125 & \text { AL-1100 } & 0.250 & 45 & 7.18 \\ 0.125 & \text { AL-1100 } & 0.250 & 45 & 7.55 \\ 0.125 & \text { AL-1100 } & 0.313 & 45 & 4.96 \\ 0.125 & \text { AL-1100 } & 0.313 & 45 & 6.24 \\ 0.125 & \text { AL-1100 } & 0.313 & 45 & 6.62 \\ 0.125 & \text { AL-1100 } & 0.187 & 0 & 3.64 \\ 0.125 & \text { AL-1100 } & 0.187 & 0 & 4.23 \\ 0.125 & \text { AL-1100 } & 0.250 & 0 & 4.25 \\ 0.125 & \text { AL-1100 } & 0.250 & 0 & 4.75 \\ 0.125 & \text { AL-1100 } & 0.313 & 0 & 5.26 \\ 0.125 & \text { AL-1100 } & 0.313 & 0 & 4.57 \\ 0.125 & \text { AL-1100 } & 0.187 & 45 & 4.13 \\ 0.125 & \text { AL-1100 } & 0.187 & 45 & 3.91 \\ 0.125 & \text { AL-1100 } & 0.187 & 45 & 3.6 \\ 0.125 & \text { AL-1100 } & 0.250 & 45 & 5.36 \\ 0.125 & \text { AL-1100 } & 0.250 & 45 & 6.96 \\ 0.125 & \text { AL-1100 } & 0.250 & 45 & 6.42 \\ 0.125 & \text { AL-1100 } & 0.313 & 45 & 5.13 \\ 0.125 & \text { AL-1100 } & 0.313 & 45 & 6.36 \\ 0.125 & \text { AL-1100 } & 0.313 & 45 & 6.91 \\ 0.125 & \text { AL-1100 } & 0.313 & 45 & 6.78\end{array}$

P3100SER. WK1 
BUMPER BUMPER BUMPER SHOT NO. TEST NO. MATERIAL THICKNESS STANDOFF

(IN)

(IN)
MLI (Y/N) MATERIAL THICKNESS

(IN)
PROJECTILE PROJECTILE IMPACT MATERIAL DIAMETER
AVERAGE ANGLE VELOCITY (DEG) (KM/S)

$\begin{array}{lccc}966 & 3202 & 6061-\mathrm{T} 6 & 0.040 \\ 1010 & 3202-\mathrm{A} & 6061-\mathrm{T} 6 & 0.080 \\ 1011 & 3202-\mathrm{B} & 6061-\mathrm{T} 6 & 0.080 \\ 1012 & 3202-\mathrm{C} & 6061-\mathrm{T} 6 & 0.080 \\ 967 & 3205 & 6061-\mathrm{T} 6 & 0.040 \\ 969 & 3206 & 6061-\mathrm{T} 6 & 0.040 \\ 970 & 3207 & 6061-\mathrm{T} 6 & 0.032 \\ 971 & 3208 & 6061-\mathrm{T} 6 & 0.032 \\ 972 & 3209 & 6061-\mathrm{T} 6 & 0.040 \\ 983 & 3209-1 & 6061-\mathrm{T} 6 & 0.040 \\ 974 & 3210 & 6061-\mathrm{T} 6 & 0.032 \\ 973 & 3211 & 6061-\mathrm{T} 6 & 0.040 \\ 975 & 3212 & 6061-\mathrm{T} 6 & 0.040 \\ 982 & 3212-1 & 6061-\mathrm{T} 6 & .032 \\ 976 & 3213 & 6061-\mathrm{T} 6 & 0.040 \\ 977 & 3214 & 6061-\mathrm{T} 6 & 0.040 \\ 978 & 3215 & 6061-\mathrm{T} 6 & 0.040 \\ 980 & 3216 & 6061-\mathrm{T} 6 & 0.040 \\ 979 & 3217 & 6061-\mathrm{T} 6 & 0.032 \\ 981 & 3218 & 6061-\mathrm{T} 6 & 0.040 \\ 984 & 3220-\mathrm{A} & 6061-\mathrm{T} 6 & 0.032 \\ 985 & 3220-\mathrm{B} & 6061-\mathrm{T} 6 & 0.032 \\ 986 & 3221-\mathrm{A} & 6061-\mathrm{T} 6 & 0.032 \\ 987 & 3221-\mathrm{B} & 6061-\mathrm{T} 6 & 0.032 \\ 988 & 3222-\mathrm{A} & 6061-\mathrm{T} 6 & 0.032 \\ 991 & 3223-\mathrm{A} & 6061-\mathrm{T} 6 & 0.063 \\ 990 & 3224-\mathrm{A} & 6061-\mathrm{T} 6 & 0.063 \\ 989 & 3224-\mathrm{B} & 6061-\mathrm{T} 6 & 0.063 \\ 992 & 3225 & 6061-\mathrm{T} 6 & 0.032 \\ 993 & 3225-\mathrm{A} & 6061-\mathrm{T} 6 & 0.032 \\ 1009 & 3225-\mathrm{C} & 6061-\mathrm{T} 6 & 0.032 \\ 995 & 3226-\mathrm{A} & 6061-\mathrm{T} 6 & 0.063 \\ 994 & 3226-\mathrm{B} & 6061-\mathrm{T} 6 & 0.063 \\ 996 & 3226-\mathrm{C} & 6061-\mathrm{T} 6 & 0.063 \\ 997 & 3227-\mathrm{A} & 6061-\mathrm{T} 6 & 0.063 \\ 1902 & 3227-\mathrm{B} & 6061-\mathrm{T} 6 & 0.063 \\ 998 & 3227-\mathrm{C} & 6061-\mathrm{T} 6 & 0.063 \\ 1000 & 3227-\mathrm{O} & 6061-\mathrm{T} 6 & 0.063\end{array}$

$\begin{array}{cll}\text { YES } & 2219-\mathrm{T} 87 & 0.125 \\ \text { YES/0.B. } & 2219-\mathrm{T} 87 & 0.125 \\ \text { YES/O.B. } & 2219-\mathrm{T} 87 & 0.125 \\ \text { YES/0.B. } & 2219-\mathrm{T} 87 & 0.125 \\ \text { YES } & 2219-\mathrm{r} 87 & 0.125 \\ \text { YES } & 2219-\mathrm{T} 87 & 0.125 \\ \text { YES } & 2219-\mathrm{T} 87 & 0.125 \\ \text { YES } & 2219-\mathrm{T} 87 & 0.125 \\ \text { YES } & 2219-\mathrm{T} 87 & 0.125 \\ \text { YES } & 2219-\mathrm{r} 87 & 0.125 \\ \text { YES } & 2219-\mathrm{T} 87 & 0.125 \\ \text { YES } & 2219-\mathrm{T} 87 & 0.125 \\ \text { YES } & 2219-\mathrm{T} 87 & 0.125 \\ \text { YES } & 2219-\mathrm{T} 87 & 0.125 \\ \text { YES } & 2219-\mathrm{T} 87 & 0.125 \\ \text { YES } & 2219-\mathrm{T} 87 & 0.125 \\ \text { YES } & 2219-\mathrm{T} 87 & 0.125 \\ \text { YES } & 2219-\mathrm{T} 87 & 0.125 \\ \text { YES } & 2219-\mathrm{T} 87 & 0.125 \\ \text { YES } & 2219-\mathrm{r} 87 & 0.125 \\ \text { YES } & 2219-\mathrm{T} 87 & 0.125 \\ \text { YES } & 2219-\mathrm{T} 87 & 0.125 \\ \text { YES } & 2219-\mathrm{T} 87 & 0.125 \\ \text { YES } & 2219-\mathrm{T} 87 & 0.125 \\ \text { YES } & 2219-\mathrm{T} 87 & 0.125 \\ \text { YES } & 2219-\mathrm{T} 87 & 0.125 \\ \text { YES } & 2219-\mathrm{T} 87 & 0.125 \\ \text { YES } & 2219-\mathrm{T} 87 & 0.125 \\ \text { YES } & 2219-\mathrm{T} 87 & 0.125 \\ \text { YES } & 2219-\mathrm{T} 87 & 0.125 \\ \text { YES } & 2219-\mathrm{T} 87 & 0.125 \\ \text { YES } & 2219-\mathrm{T} 87 & 0.125 \\ \text { YES } & 2219-\mathrm{T} 87 & 0.125 \\ \text { YES } & 2219-\mathrm{T} 87 & 0.125 \\ \text { YES } & 2219-\mathrm{T} 87 & 0.125 \\ \text { YES } & 2219-\mathrm{T} 87 & 0.125 \\ \text { YES } & 2219-\mathrm{T} 87 & 0.125 \\ \text { YES/OB } & 2219-\mathrm{T} 87 & 0.125 \\ & & \end{array}$

\begin{tabular}{|c|c|}
\hline$A L-1100$ & 0.187 \\
\hline$A L-1100$ & 0.313 \\
\hline$A L-1100$ & 0.313 \\
\hline$A L-1100$ & 0.313 \\
\hline AL -1100 & 0.25 \\
\hline$A L-1100$ & 0.25 \\
\hline$A L-1100$ & 0.25 \\
\hline$A L-1100$ & 0.25 \\
\hline$A L-1100$ & 0.25 \\
\hline$A L-1100$ & 0.25 \\
\hline$A L-1100$ & 0.25 \\
\hline$A L-1100$ & 0.25 \\
\hline$A L-1100$ & 0.313 \\
\hline$A L-1100$ & 0.313 \\
\hline$A L-1100$ & 0.313 \\
\hline$A L-1100$ & 0.313 \\
\hline$A L-1100$ & 0.313 \\
\hline$A L-1100$ & 0.313 \\
\hline$A L-1100$ & 0.313 \\
\hline$A L-1100$ & 0.313 \\
\hline$A L-1100$ & 0.313 \\
\hline$A L-1100$ & 0.313 \\
\hline$A L-1100$ & 0.25 \\
\hline$A L-1100$ & 0.25 \\
\hline$A L=1100$ & 0.187 \\
\hline AL -1100 & 0.313 \\
\hline$A L-1100$ & 0.25 \\
\hline$A L-1100$ & 0.25 \\
\hline$A L-1100$ & 0.375 \\
\hline$A L-1100$ & 0.375 \\
\hline$A L-1100$ & 0.375 \\
\hline $\begin{array}{l}A L-1100 \\
A L-1100\end{array}$ & $\begin{array}{l}0.375 \\
0.375\end{array}$ \\
\hline$A L-1100$ & 0.375 \\
\hline$A L-1100$ & 0.375 \\
\hline$A L-1100$ & 0.375 \\
\hline$A L-1100$ & 0.375 \\
\hline$A L-1100$ & 0.375 \\
\hline
\end{tabular}

7.20

6.43

6.72

6.75

6.80

6.48

3.80

5.83

4.61

5.60

5.67

3.43

3.57

4.46

5.16

5.65

6.31

6.05

6.49

5.96

6.48

6.20

6.37

5.55

5.85

5.15

5.26

5.94

5.91

6.24

5.62

5.55

5.97

6.80

6.70

6.56

6.90 


\begin{tabular}{|c|c|c|c|c|c|c|c|c|c|}
\hline $\begin{array}{l}\text { BUMPER } \\
\text { MATERIAL }\end{array}$ & $\begin{array}{l}\text { BUMPER } \\
\text { THICKNESS } \\
\text { (IN) }\end{array}$ & $\begin{array}{l}\text { BUMPER } \\
\text { STANDOFF } \\
\text { (IN) }\end{array}$ & $\begin{array}{c}\text { MLI } \\
(Y / N)\end{array}$ & $\begin{array}{l}\text { BACKWALL } \\
\text { MATERIAL }\end{array}$ & $\begin{array}{l}\text { BACKWALL } \\
\text { THICKNESS } \\
\text { (IN) }\end{array}$ & $\begin{array}{l}\text { PROJECTILE } \\
\text { MATERIAL }\end{array}$ & $\begin{array}{l}\text { PROJECTIL } \\
\text { DIAMETER }\end{array}$ & $\begin{array}{l}\text { IMPACT } \\
\text { ANGLE } \\
\text { (DEG) }\end{array}$ & $\begin{array}{l}\text { AVERAGE } \\
\text { VELOCI TY } \\
\text { (KM/S) }\end{array}$ \\
\hline $6061-T 6$ & 0.08 & 4 & YES/O.B. & 2219-T87 & 0.125 & AL- 1100 & 0.250 & 0 & 3.93 \\
\hline $6061-T 6$ & 0.08 & 4 & YES/O.B. & 2219-T87 & 0.125 & AL-1100 & 0.250 & 0 & 4.27 \\
\hline $6061-T 6$ & 0.08 & 4 & YES/O.B. & 2219-T87 & 0.125 & $A L-1100$ & 0.250 & 0 & 6.27 \\
\hline $6061-16$ & 0.08 & 4 & YES/O.B. & 2219-T87 & 0.125 & $A L-1100$ & 0.250 & 0 & 5.48 \\
\hline $6061-T 6$ & 0.08 & 4 & YES/0.25" & $2219-187$ & 0.125 & AL- 1100 & 0.250 & 0 & 4.98 \\
\hline $6061-16$ & 0.08 & 4 & YES/0.25" & 2219-T87 & 0.125 & AL- -1100 & 0.313 & 0 & 6.22 \\
\hline $6061-16$ & 0.08 & 4 & YES/0.25" & $2219-T 87$ & 0.125 & AL- 1100 & 0.187 & 45 & 6.41 \\
\hline $6061-16$ & 0.08 & 4 & YES/0.25" & 2219-T87 & 0.125 & $A L-1100$ & 0.187 & 45 & 6.77 \\
\hline $6061-\mathrm{T} 6$ & 0.08 & 4 & YES/0.25" & $2219-\mathrm{T} 87$ & 0.125 & AL-1100 & 0.187 & 45 & 6.13 \\
\hline $6061-16$ & 0.08 & 4 & YES/0.25" & 2219-T87 & 0.125 & AL- 1100 & 0.187 & 45 & 5.65 \\
\hline $6061-16$ & 0.08 & 4 & YES/0.25" & 2219-T87 & 0.125 & AL -1100 & 0.250 & 45 & 6.2 \\
\hline $6061-T 6$ & 0.08 & 4 & YES/0.25" & 2219-T87 & 0.125 & $A L-1100$ & 0.250 & 45 & 6.28 \\
\hline $6061-16$ & 0.08 & 4 & YES/0.25" & 2219-T87 & 0.125 & $A L-1100$ & 0.250 & 45 & 6.84 \\
\hline $6061-\mathrm{T} 6$ & 0.08 & 4 & YES/0.25" & $2219-\mathrm{T} 87$ & 0.125 & AL -1100 & 0.250 & 45 & 6.91 \\
\hline $6061-T 6$ & 0.063 & 4 & YES/0.25" & $2219-\mathrm{T} 87$ & 0.125 & $A L-1100$ & 0.187 & 0 & 4.63 \\
\hline 6061-T6 & 0.063 & 4 & YES/0.25" & $2219-T 87$ & 0.125 & $A L-1100$ & 0.187 & 0 & 4.18 \\
\hline $6061-16$ & 0.063 & 4 & YES/0.25" & 2219-T87 & 0.125 & $A L-1100$ & 0.187 & 0 & 3.79 \\
\hline 6061-T6 & 0.063 & 4 & YES/0.25" & $2219-\mathrm{T} 87$ & 0.125 & $A L-1100$ & 0.250 & 0 & 5.22 \\
\hline $6061-T 6$ & 0.063 & 4 & YES/0.25" & 2219-T87. & 0.125 & $A L-1100$ & 0.250 & 0 & 6.98 \\
\hline $6061-T 6$ & 0.063 & 4 & YES/0.25" & 2219-T87 & 0.125 & AL- 1100 & 0.250 & 0 & 7.05 \\
\hline $6061-T 6$ & 0.063 & 4 & YES/0.25" & $2219-T 87$ & 0.125 & $A L-1100$ & 0.250 & 0 & 6.98 \\
\hline $6061-T 6$ & 0.063 & 4 & YES/0.25" & 2219-T87 & 0.125 & $A L-1100$ & 0.187 & 45 & 4.75 \\
\hline $6061-16$ & 0.063 & 4 & YES/0.25" & 2219-T87 & 0.125 & $A L-1100$ & 0.187 & 45 & 6.28 \\
\hline 6061-T6 & 0.063 & 4 & YES/0.25" & $2219-T 87$ & 0.125 & $A L-1100$ & 0.250 & 45 & 5.2 \\
\hline $6061-T 6$ & 0.063 & 4 & YES/0.25" & 2219-T87 & 0.125 & $A L-1100$ & 0.250 & 45 & 6.21 \\
\hline
\end{tabular}

P3300SER. WK1 


\begin{tabular}{|c|c|c|c|c|c|c|c|c|c|c|c|}
\hline SHOT NO. & TEST NO. & $\begin{array}{l}\text { BUMPER } \\
\text { MATERIALL }\end{array}$ & $\begin{array}{l}\text { BUMPER } \\
\text { THICKNESS } \\
\text { (IN) }\end{array}$ & $\begin{array}{l}\text { BUMPER } \\
\text { STANDOFF } \\
\text { (IN) }\end{array}$ & $\begin{array}{l}M L I \\
(Y / N)\end{array}$ & $\begin{array}{l}\text { BACKWALL } \\
\text { MATERIAL }\end{array}$ & $\begin{array}{c}\text { BACKWALL } \\
\text { THICKNESS } \\
\text { (IN) }\end{array}$ & $\begin{array}{l}\text { PROJECTILE } \\
\text { MATERIAL }\end{array}$ & $\begin{array}{l}\text { PROJECTILE } \\
\text { DIAMETER }\end{array}$ & $\begin{array}{r}\text { IMPACT } \\
\text { ANGLE } \\
\text { (DEG) }\end{array}$ & $\begin{array}{l}\text { AVERAGE } \\
\text { VELOCITY } \\
\text { (KM/S) }\end{array}$ \\
\hline 1140 & $3401-A$ & $6061-T 6$ & 0.063 & 4 & YES/2" O.B. & 2219-T87 & 0.125 & $A L-1100$ & 0.313 & 0 & 7.22 \\
\hline 1144 & $3401-B$ & $6061-16$ & 0.063 & 4 & YES/2" O.B. & 2219-T87 & 0.125 & AL -1100 & 0.313 & 0 & 7.09 \\
\hline 1139 & $3401-C$ & $6061-T 6$ & 0.063 & 4 & YES/2" O.B. & 2219-T87 & 0.125 & $A L-1100$ & 0.313 & 0 & 6.12 \\
\hline 1138 & $3401-D$ & $6061-T 6$ & 0.063 & 4 & YES/2" O.B. & $2219-T 87$ & 0.125 & $A L-1100$ & 0.313 & 0 & 5.25 \\
\hline 1143 & $3402-A$ & $6061-16$ & 0.063 & 4 & YES/2" O.B. & 2219-T87 & 0.125 & $A L-1100$ & 0.313 & 0 & 7.18 \\
\hline 1145 & $3402-B$ & $6061-T 6$ & 0.063 & 4 & YES/2" O.B. & $2219-T 87$ & 0.125 & $A L-1100$ & 0.313 & 0 & 7.1 \\
\hline 1142 & $3402-c$ & $6061-\mathrm{T} 6$ & 0.063 & 4 & YES/2" O.B. & 2219-T87 & 0.125 & $A L-1100$ & 0.313 & 0 & 6.17 \\
\hline 1141 & $3402-D$ & $6061-T 6$ & 0.063 & 4 & YES/2" O.B. & 2219-T87 & 0.125 & $A L-1100$ & 0.313 & 0 & 5.02 \\
\hline 1149 & 3403-A & $6061-T 6$ & 0.063 & 4 & YES/0.25" O.B. & 2219-T87 & 0.125 & AL -1100 & 0.313 & 0 & 7.15 \\
\hline 1148 & $3403-B$ & $6061-T 6$ & 0.063 & 4 & YES/0.25" O.B. & $2219-T 87$ & 0.125 & $A L-1100$ & 0.313 & 0 & 7.1 \\
\hline 1147 & $3403-C$ & $6061-16$ & 0.063 & 4 & YES/0.25" 0.8. & 2219-T87 & 0.125 & $A L-1100$ & 0.313 & 0 & 6.2 \\
\hline 1146 & $3403-0$ & $6061-T 6$ & 0.063 & 4 & YES/0.25" O.B. & $2219-T 87$ & 0.125 & $A L-1100$ & 0.313 & 0 & 5.03 \\
\hline 1152 & $3404-A$ & $6061-T 6$ & 0.063 & 4 & YES/2" 0.8 . & $2219-187$ & 0.125 & $A L-1100$ & 0.375 & 0 & 6.85 \\
\hline 1153 & $3404-8$ & $6061-\mathrm{T} 6$ & 0.063 & 4 & YES/2" O.B. & $2219-T 87$ & 0.125 & $A L-1100$ & 0.375 & 0 & 6.85 \\
\hline 1154 & $3404-C$ & $6061-\mathrm{T} 6$ & 0.063 & 4 & YES/2" O.B. & 2219-T87 & 0.125 & $A L-1100$ & 0.375 & 0 & 6.23 \\
\hline 1156 & $3404-0$ & $6061-T 6$ & 0.063 & 4 & YES/2" O.B. & 2219-T87 & 0.125 & $A L-1100$ & 0.375 & 0 & 5.5 \\
\hline 1165 & $3405-A$ & $6061-\mathrm{T} 6$ & 0.063 & 4 & YES/2" O.B. & 2219-T87 & 0.125 & $A L-1100$ & 0.250 & 0 & 3.03 \\
\hline 1166 & $3405-8$ & $6061-16$ & 0.063 & 4 & YES/2" O.B. & 2219-T87 & 0.125 & $A L-1100$ & 0.250 & 0 & 3.83 \\
\hline 1167 & $3405-C$ & $6061-\mathrm{T} 6$ & 0.063 & 4 & YES/2" O.B. & $2219-187$ & 0.125 & $A L-1100$ & 0.250 & 0 & 5.1 \\
\hline 1168 & $3405-D$ & $6061-16$ & 0.063 & 4 & YES/2" O.B. & 2219-T87 & 0.125 & $A L-1100$ & 0.250 & 0 & 6.2 \\
\hline 1161 & $3406-A$ & $6061-\mathrm{T} 6$ & 0.063 & 4 & YES/2" O.B. & 2219-T87 & 0.125 & $A L-1100$ & 0.250 & 0 & 3.06 \\
\hline 1162 & 3406-B & $6061-16$ & 0.063 & 4 & YES/2" O.B. & 2219-T87 & 0.125 & $A L-1100$ & 0.250 & 0 & 4.05 \\
\hline 1163 & $3406-C$ & $6061-T 6$ & 0.063 & 4 & YES/2" O.B. & 2219-T87 & 0.125 & $A L-1100$ & 0.250 & 0 & 5.16 \\
\hline 1164 & 3406-D & $6061-\mathrm{T} 6$ & 0.063 & 4 & YES/2" O.B. & 2219-T87 & 0.125 & $A L-1100$ & 0.250 & 0 & 5.58 \\
\hline 1169 & $3406-D 1$ & 6061-T6 & 0.063 & 4 & YES/2" O.B. & 2219-T87 & 0.125 & $A L=1100$ & 0.250 & 0 & 6.09 \\
\hline 1160 & $3407-A$ & $6061-T 6$ & 0.063 & 4 & YES/0.25" O.B. & $2219-187$ & 0.125 & $A L-1100$ & 0.250 & 0 & 2.91 \\
\hline 1159 & $3407-8$ & $6061-T 6$ & 0.063 & 4 & YES/0.25" O.B. & 2219-T87 & 0.125 & $A L-1100$ & 0.250 & 0 & 3.94 \\
\hline 1158 & $3407-C$ & $6061-16$ & 0.063 & 4 & YES/0.25": O.B. & 2219-T87 & 0.125 & $A L-1100$ & 0.250 & 0 & 4.81 \\
\hline 1157 & 3407-D & $6061-16$ & 0.063 & 4 & YES/0.25" 0.B. & $2219-T 87$ & 0.125 & $A L-1100$ & 0.375 & 0 & 5.81 \\
\hline
\end{tabular}

P3400SER. WK1 


\begin{tabular}{|c|c|c|c|c|c|c|c|c|c|c|c|c|}
\hline & SHOT NO. & TEST NO. & $\begin{array}{c}\text { BUMPER } \\
\text { MATERIAL }\end{array}$ & $\begin{array}{l}\text { BUMPER } \\
\text { THICKNESS } \\
\text { (IN) }\end{array}$ & $\begin{array}{l}\text { BUMPER } \\
\text { STANDOFF } \\
\text { (IN) }\end{array}$ & $\begin{array}{c}M L I \\
(Y / N)\end{array}$ & $\begin{array}{l}\text { BACK WALL } \\
\text { MATERIAL }\end{array}$ & $\begin{array}{c}\text { BACK WALL } \\
\text { THICKNESS } \\
\text { (IN) }\end{array}$ & $\begin{array}{c}\text { PROJECTILE } \\
\text { MATERIAL }\end{array}$ & $\begin{array}{l}\text { PROJECTILE } \\
\text { DIAMETER } \\
\text { (IN) }\end{array}$ & $\begin{array}{r}\text { IMPACT } \\
\text { ANGLE } \\
\text { (DEG) }\end{array}$ & $\begin{array}{l}\text { AVERAGE } \\
\text { VELOCITY } \\
(\mathrm{KM} / \mathrm{S})\end{array}$ \\
\hline \multirow{16}{*}{ ڤ̊ } & 1042 & $4001-A$ & 6061-T6 & 0.080 & 4 & YES/0.25"O.B. & 2219-T87 & 0.125 & $A L-1100$ & 0.313 & 45 & 3.15 \\
\hline & 1040 & 4001-B & $6061-T 6$ & 0.080 & 4 & YES/0.25"O.B. & 2219-T87 & 0.125 & $A L-1100$ & 0.313 & 45 & 4.29 \\
\hline & 1041 & $4001-C$ & $6061-T 6$ & 0.080 & 4 & YES/0.25"O.B. & $2219-187$ & 0.125 & $A L-1100$ & 0.313 & 45 & 6.12 \\
\hline & 1043 & 4001-D & $6061-\mathrm{T} 6$ & 0.080 & 4 & YES/0.25"0.B. & 2219-T87 & 0.125 & $A L-1100$ & 0.313 & 45 & 6.71 \\
\hline & 1046 & $4002-A$ & $6061-16$ & 0.080 & 4 & YES/0.25"O. B. & $2219-\mathrm{T} 87$ & 0.125 & $A L-1100$ & 0.313 & 75 & 3.20 \\
\hline & 1044 & $4002-8$ & $6061-T 6$ & 0.080 & 4 & YES/0.25"0.8. & 2219-T87 & 0.125 & $A L-1100$ & 0.313 & 75 & 3.97 \\
\hline & 1045 & $4002-c$ & $6061-T 6$ & 0.080 & 4 & YES/0.25"O.8. & 2219-T87 & 0.125 & $A L-1100$ & 0.313 & 75 & 6.30 \\
\hline & 1047 & 4002-D & $6061-16$ & 0.063 & 4 & YES/0.25"O.B. & 2219-T87 & 0.125 & $A L-1100$ & 0.313 & 75 & 7.14 \\
\hline & 1056 & $4002-E$ & $6061-T 6$ & 0.080 & 4 & YES/0.25"O.B. & $2219-187$ & 0.125 & $A L-1100$ & 0.313 & 75 & 6.41 \\
\hline & 1048 & 4003-A & $6061-T 6$ & 0.063 & 4 & YES/0.25"0.8. & 2219-T87 & 0.125 & $A L-1100$ & 0.313 & 45 & 3.43 \\
\hline & 1049 & 4003-8 & $6061-16$ & 0.080 & 4 & YES/0.25"O.B. & 2219-T87 & 0.125 & $A L-1100$ & 0.313 & 45 & 6.29 \\
\hline & 1051 & $4003-C$ & $6061-T 6$ & 0.080 & 4 & YES/0.25"0.8. & 2219-T87 & 0.125 & $A L-1100$ & 0.313 & 45 & 3.18 \\
\hline & 1050 & 4003-D & $6061-\mathrm{T} 6$ & 0.080 & 4 & YES/0.25"O.B. & 2219-T87 & 0.125 & $A L-1100$ & 0.313 & 45 & 6.22 \\
\hline & 1052 & $4004-A$ & $6061-T 6$ & 0.080 & 4 & YES/0.25"O.B. & 2219-T87 & 0.125 & $A L-1100$ & 0.313 & 75 & 3.19 \\
\hline & 1053 & 4004-B & $6061-T 6$ & 0.080 & 4 & YES/0.25"O.B. & 2219-T87 & 0.125 & $A L-1100$ & 0.313 & 75 & 6.08 \\
\hline & 1054 & $4004-C$ & $6061-16$ & 0.080 & 4 & YES/0.25"O.B. & $2219-T 87$ & 0.125 & $A L-1100$ & 0.313 & 75 & 6.19 \\
\hline
\end{tabular}

P4000SER . WK1 


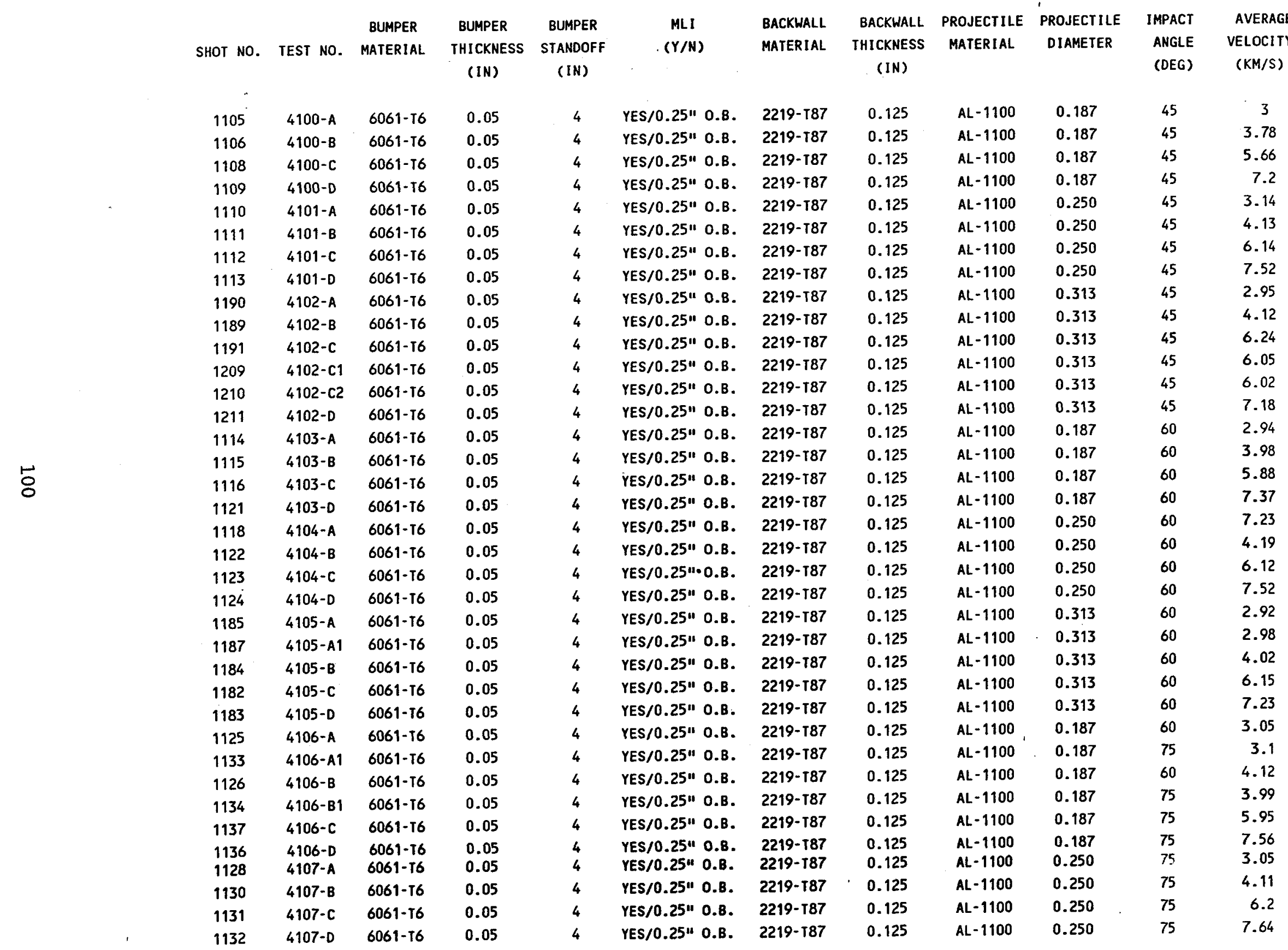




\begin{tabular}{|c|c|c|c|c|c|c|c|c|c|c|c|c|c|}
\hline & SHOT NO. & TEST NO. & $\begin{array}{l}\text { BUMPER } \\
\text { MATERIAL }\end{array}$ & $\begin{array}{l}\text { BUMPER } \\
\text { THICKNESS } \\
\text { (IN) }\end{array}$ & $\begin{array}{c}\text { BUMPER } \\
\text { STANDOFF } \\
\text { (IN) }\end{array}$ & $\begin{array}{c}M L I \\
(Y / N)\end{array}$ & & $\begin{array}{l}\text { BACKWALL } \\
\text { MATERIAL }\end{array}$ & $\begin{array}{l}\text { BACKWALL } \\
\text { IHICKNESS } \\
\text { (IN) }\end{array}$ & $\begin{array}{l}\text { PROJECTILE } \\
\text { MATERIAL }\end{array}$ & $\begin{array}{l}\text { PROJECTILE } \\
\text { DIAMETER }\end{array}$ & $\begin{array}{r}\text { IMPACT } \\
\text { ANGLE } \\
\text { (DEG) }\end{array}$ & $\begin{array}{c}\text { AVERAGE } \\
\text { VELOCITY } \\
(\mathrm{KM} / \mathrm{S})\end{array}$ \\
\hline & 1186 & 4108-A & $6061-T 6$ & 0.05 & 4 & YES/0.25" & O.B. & 2219-T87 & 0.125 & $A L-1100$ & 0.313 & 75 & 3.12 \\
\hline & 1188 & 4108-A1 & $6061-T 6$ & 0.05 & 4 & YES/0.25" & O.B. & 2219-T87 & 0.125 & $A L-1100$ & 0.313 & 75 & 2.95 \\
\hline & 1179 & $4108-8$ & $6061-T 6$ & 0.05 & 4 & YES/0.25" & 0.8. & 2219-T87 & 0.125 & $A L-1100$ & 0.313 & 75 & 3.97 \\
\hline & 1180 & 4108-C & $6061-T 6$ & 0.05 & 4 & YES/0.25" & 0.8. & 2219-ז87 & 0.125 & $A L-1100$ & 0.313 & 75 & 5.96 \\
\hline & 1181 & 4108-D & $6061-16$ & 0.05 & 4 & YES/0.25" & 0.8. & 2219-T87 & 0.125 & $A L-1100$ & 0.313 & 75 & 7.07 \\
\hline & 1058 & $4109-A$ & $6061-T 6$ & 0.08 & 4 & YES/0.25" & O.B. & 2219-T87 & 0.125 & $A L=1100$ & 0.187 & 45 & 3.27 \\
\hline & 1059 & $4109-B$ & $6061-T 6$ & 0.08 & 4 & YES/0.25" & O.B. & 2219-T87 & 0.125 & $A L=1100$ & 0.187 & 45 & 4.14 \\
\hline & 1060 & $4109-C$ & $6061-T 6$ & 0.08 & 4 & YES/0.25" & O.B. & 2219-T87 & 0.125 & $A L-1100$ & 0.187 & 45 & 6.53 \\
\hline & 1062 & $4109-0$ & $6061-T 6$ & 0.08 & 4 & YES/0.25" & 0.8 & 2219-T87 & 0.125 & $A L-1100$ & 0.187 & 45 & 7.46 \\
\hline & 1064 & $4110-A$ & $6061-T 6$ & 0.08 & 4 & YES/0.25" & 0.8 . & 2219-T87 & 0.125 & $A L-1100$ & 0.250 & 45 & 3.25 \\
\hline & 1065 & $4110-8$ & $6061-16$ & 0.08 & 4 & YES/0.25" & O.B. & $2219-\mathrm{T} 87$ & 0.125 & $A L-1100$ & 0.250 & 45 & 4 \\
\hline & $\begin{array}{l}1068 \\
1069\end{array}$ & $\begin{array}{l}4110-C \\
4110-0\end{array}$ & $\begin{array}{l}6061-\mathrm{T} 6 \\
6061-\mathrm{T} 6\end{array}$ & $\begin{array}{l}0.08 \\
0.08\end{array}$ & $\begin{array}{l}4 \\
4\end{array}$ & $\begin{array}{l}\text { YES/0.25" } \\
\text { YES/0.25" }\end{array}$ & O.B. & $\begin{array}{l}2219-187 \\
2219-\mathrm{T} 87\end{array}$ & $\begin{array}{l}0.125 \\
0.125\end{array}$ & $\begin{array}{l}A L-1100 \\
A L-1100\end{array}$ & $\begin{array}{l}0.250 \\
0.250\end{array}$ & $\begin{array}{l}45 \\
45\end{array}$ & $\begin{array}{l}5.76 \\
6.96\end{array}$ \\
\hline & 1070 & $4111-A$ & $6061-T 6$ & 0.08 & 4 & YES/0.25" & O.B. & 2219-T87 & 0.125 & $A L-1100$ & 0.313 & 45 & 2.85 \\
\hline & 1071 & 4111-B & $6061-T 6$ & 0.08 & 4 & YES/0.25" & 0.8 & 2219-T87 & 0.125 & $A L-1100$ & 0.313 & 45 & 3.94 \\
\hline & 1072 & $4111-\mathrm{C}$ & $6061-\mathrm{T} 6$ & 0.08 & 4 & YES/0.25" & 0.8 & 2219-T87 & 0.125 & $A L-1100$ & 0.313 & 45 & 5.97 \\
\hline & 1073 & 4111-D & $6061-T 6$ & 0.08 & 4 & YES/0.25" & O.B. & 2219-T87 & 0.125 & $A L-1100$ & 0.313 & 45 & 6.81 \\
\hline & 1074 & 4112-A & $6061-\mathrm{T} 6$ & 0.08 & 4 & YES/0.25" & 0.8 & 2219-T87 & 0.125 & $A L-1100$ & 0.187 & 60 & 3.33 \\
\hline & 1075 & 4112-B & $6061-T 6$ & 0.08 & 4 & YES/0.25" & 0.8 & 2219-T87 & 0.125 & $A L-1100$ & 0.187 & 60 & 4.05 \\
\hline$\stackrel{\circ}{\mapsto}$ & 1076 & $4112-C$ & $6061-T 6$ & 0.08 & 4 & YES/0.25" & O.B. & 2219-T87 & 0.125 & $A L-1100$ & 0.187 & 60 & 5.87 \\
\hline & 1077 & $4112-0$ & $6061-T 6$ & 0.08 & 4 & YES/0.25" & O.B. & 2219-T87 & 0.125 & $A L-1100$ & 0.187 & 60 & 7.5 \\
\hline & 1078 & 4113-A & $6061-T 6$ & 0.08 & 4 & YES/0.25" & O.B. & 2219-T87 & 0.125 & $A L-1100$ & 0.250 & 60 & 2.97 \\
\hline & 1079 & 4113-B & $6061-T 6$ & 0.08 & 4 & YES/0.25" & 0.8 . & 2219-T87 & 0.125 & $A L-1100$ & 0.250 & 60 & 3.77 \\
\hline & 1080 & 4113-C & 6061-T6 & 0.08 & 4 & YES/0.25" & 0.8 . & 2219-T87 & 0.125 & $A L-1100$ & 0.250 & 60 & 6.3 \\
\hline & 1082 & 4113-D & $6061-T 6$ & 0.08 & 4 & YES/0.25" & O.B. & 2219-T87 & 0.125 & AL -1100 & 0.250 & 60 & 7.12 \\
\hline & 1083 & 4114-A & $6061-T 6$ & 0.08 & 4 & YES/0.25" & O.B. & 2219-T87 & 0.125 & $A L-1100$ & 0.313 & 60 & 3.13 \\
\hline & 1084 & 4114-B & $6061-T 6$ & 0.08 & 4 & YES/0.25" & 0.8 . & $2219-187$ & 0.125 & $A L-1100$ & 0.313 & 60 & 3.98 \\
\hline & 1085 & 4114-C & $6061-T 6$ & 0.08 & 4 & YES/0.25" & O.B. & 2219-T87 & 0.125 & $A L-1100$ & 0.313 & 60 & 5.92 \\
\hline & 1086 & 4114-D & $6061-16$ & 0.08 & 4 & YES/0.25" & O.B. & 2219-T87 & 0.125 & $A L-1100$ & 0.313 & 60 & 7.4 \\
\hline & 1089 & 4115-A & $6061-T 6$ & 0.08 & 4 & YES/0.25" & O.B. & 2219-T87 & 0.125 & $A L-1100$ & 0.187 & 75 & 3.13 \\
\hline & $\begin{array}{l}1088 \\
1090\end{array}$ & $\begin{array}{l}4115-B \\
4115-C\end{array}$ & $\begin{array}{l}6061-T 6 \\
6061-T 6\end{array}$ & $\begin{array}{l}0.08 \\
0.08\end{array}$ & $\begin{array}{l}4 \\
4\end{array}$ & $\begin{array}{l}\text { YES/0.25" } \\
\text { YES/0.25" }\end{array}$ & O.B. & $\begin{array}{l}2219-T 87 \\
2219-T 87\end{array}$ & $\begin{array}{l}0.125 \\
0.125\end{array}$ & $\begin{array}{l}A L-1100 \\
A L-1100\end{array}$ & $\begin{array}{l}0.187 \\
0.187\end{array}$ & $\begin{array}{l}75 \\
75\end{array}$ & $\begin{array}{l}4.08 \\
6.06\end{array}$ \\
\hline & 1091 & 4115-D & $6061 \cdot T 6$ & 0.08 & 4 & YES/0.25" & O.B. & 2219-T87 & 0.125 & $A L-1100$ & 0.187 & 75 & 7.3 \\
\hline & 1092 & 4116-A & $6061-T 6$ & 0.08 & 4 & YES/0.25" & O.B. & 2219-T87 & 0.125 & $A L=1100$ & 0.250 & 75 & 2.92 \\
\hline & 1093 & 4116-B & $6061-16$ & 0.08 & 4 & YES/0.25" & 0.8. & $2219-T 87$ & 0.125 & $A L-1100$ & 0.250 & 75 & 4.48 \\
\hline & 1094 & $4116-C$ & $6061-T 6$ & 0.08 & 4 & YES/0.25" & O.B. & 2219-T87 & 0.125 & $A L-1100$ & 0.250 & 75 & 6.24 \\
\hline & 1095 & 4116-0 & $6061-T 6$ & 0.08 & 4 & YES/0.25" & 0.8 & 2219-T87 & 0.125 & $A L-1100$ & 0.250 & 75 & 7.36 \\
\hline & 1096 & 4117-A & $6061-16$ & 0.08 & 4 & YES/0.25" & 0.8 . & $2219-187$ & 0.125 & $A L-1100$ & 0.313 & 75 & 3.11 \\
\hline & 1097 & 4117-B & $6061-16$ & 0.08 & 4 & YES/0.25" & O.B. & 2219-T87 & 0.125 & $A L-1100$ & 0.313 & 75 & 4.05 \\
\hline & 1098 & 4117-C & $6061-16$ & 0.08 & 4 & YES/0.25" & O.B. & 2219-T87 & 0.125 & $A L-1100$ & 0.313 & 75 & 6.03 \\
\hline & 1103 & 4117-D & $6061-T 6$ & 0.08 & 4 & YES/0.25" & O.B. & $2219-187$ & 0.125 & $A L-1100$ & 0.313 & 75 & 7.2 \\
\hline
\end{tabular}




\begin{tabular}{|c|c|c|c|c|c|c|c|c|c|c|c|}
\hline SHOT NO. & TEST NO. & $\begin{array}{c}\text { BUMPER } \\
\text { MATERIAL }\end{array}$ & $\begin{array}{l}\text { BUMPER } \\
\text { THICKNESS } \\
\text { (IN) }\end{array}$ & $\begin{array}{l}\text { BUMPER } \\
\text { STANDOFF } \\
\text { (IN) }\end{array}$ & $\begin{array}{c}\text { MLI } \\
(Y / N)\end{array}$ & $\begin{array}{l}\text { BACK HALL } \\
\text { MATERIAL }\end{array}$ & $\begin{array}{l}\text { BACK HALL } \\
\text { THICKNESS } \\
\text { (IN) }\end{array}$ & $\begin{array}{l}\text { PROJECTILE } \\
\text { MATERIAL }\end{array}$ & $\begin{array}{l}\text { PROJECTILE } \\
\text { DIAMETER } \\
\text { (IN) }\end{array}$ & $\begin{array}{l}\text { IMPACT } \\
\text { ANGLE } \\
\text { (DEG) }\end{array}$ & $\begin{array}{c}\text { AVERAGE } \\
\text { VELOCITY } \\
\text { (KM/S) }\end{array}$ \\
\hline 1170 & $9001-1$ & $6061-16$ & 0.063 & 4 & YES/0.25"O.B. & 2219-T87 & 0.125 & $A L-1100$ & 0.250 & 45 & 6.00 \\
\hline 1171 & $9001-A$ & $6061-16$ & 0.050 & 4 & YES/0.25"0.B. & 2219-T87 & 0.125 & $A L-1100$ & 0.250 & 45 & 5.97 \\
\hline 1172 & $9001-B$ & 6061-T6 & 0.050 & 4 & YES/0.25"O.B. & 2219-T87 & 0.125 & AL -1100 & 0.250 & 45 & 5.92 \\
\hline 1173 & $9001-c$ & $6061-T 6$ & 0.050 & 4 & YES/0.25"O.B. & 2219-T87 & 0.125 & $A L-1100$ & 0.250 & 45 & 5.94 \\
\hline 1174 & 9001-D & $6061-16$ & 0.050 & 4 & YES/0.25"0.8. & $2219-\tau 87$ & 0.125 & AL-1100 & 0.250 & 45 & 6.11 \\
\hline 1175 & $9002-A$ & $6061-16$ & 0.050 & 4 & YES/0.25"O.B. & $2219-187$ & 0.125 & AL- 1100 & 0.250 & 45 & 6.39 \\
\hline 1176 & $9002-B$ & $6061-16$ & 0.050 & 4 & YES/0.25"O.8. & $2219-T 87$ & 0.125 & AL -1100 & 0.250 & 45 & 6.40 \\
\hline 1177 & $9002-C$ & $6061-16$ & 0.050 & 4 & YES/0.25"O.B. & 2219- T87 & 0.125 & $A L-1100$ & 0.250 & 45 & 6.35 \\
\hline 1178 & $9002-0$ & $6061-16$ & 0.050 & 4 & YES/0.25"O.B. & 2219-T87 & 0.125 & AL -1100 & 0.250 & 45 & 6.37 \\
\hline
\end{tabular}

P9000SER . WK1 


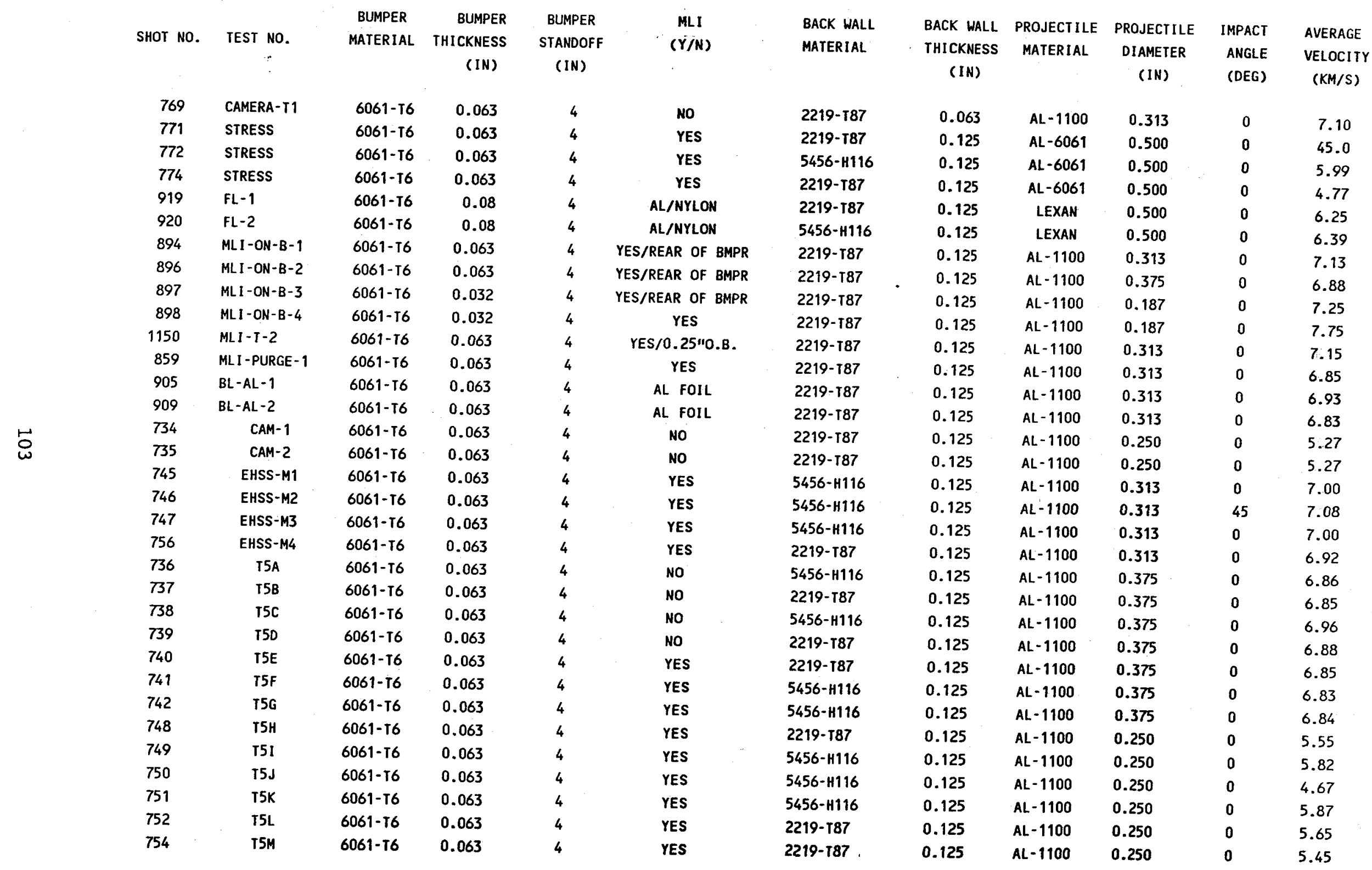




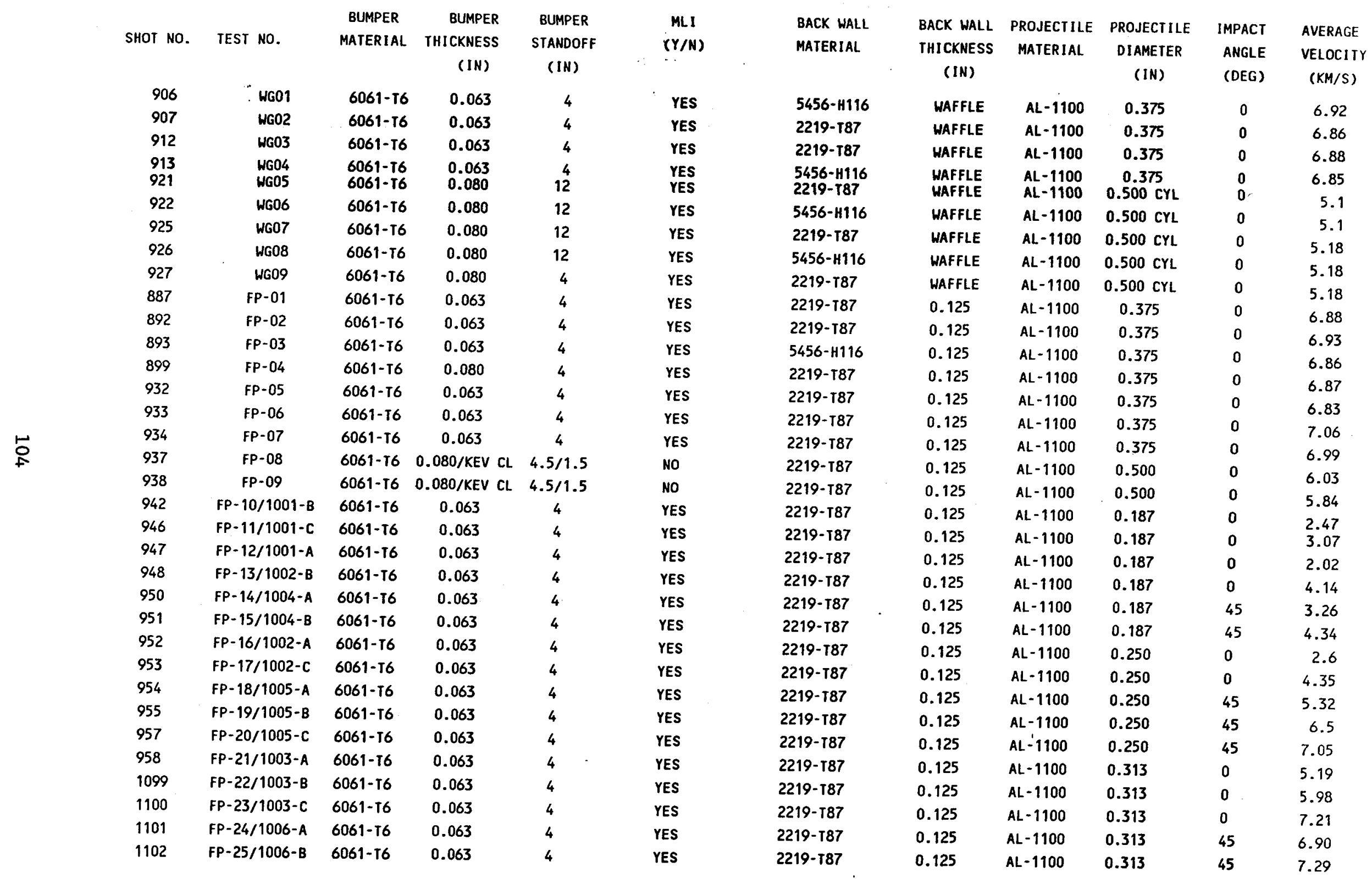

PMISC.WK1 (Continued) 
APPENDIX II -- PHASE C/D TESTING DAMAGE DATABASE 


\begin{tabular}{|c|c|c|c|c|c|c|c|c|c|c|c|c|c|c|c|c|c|}
\hline \multirow[t]{2}{*}{ SHOT NO. } & \multirow[t]{2}{*}{ TEST NO. } & \multirow{2}{*}{$\begin{array}{l}\text { BUMPER } \\
\text { DHIN }\end{array}$} & \multirow{2}{*}{$\begin{array}{l}\text { PLATE HOLE } \\
\text { DMAX }\end{array}$} & \multirow{2}{*}{$\begin{array}{l}\text { BACKWALLL } \\
\text { PERFORATED? }\end{array}$} & \multirow{2}{*}{$\begin{array}{l}\text { BACKWALL EO } \\
\text { HOLE DIAMETER } \\
\text { (IN) }\end{array}$} & \multirow{2}{*}{$\begin{array}{l}\text { BACKUALL } \\
\text { DAMAGE AREA } \\
\text { (SO. IN.) }\end{array}$} & \multirow{2}{*}{$\begin{array}{l}\text { BACKUALL } \\
\text { SPALLED? }\end{array}$} & \multirow{2}{*}{$\begin{array}{l}\text { BACKUALL } \\
\text { SPALL. AREA } \\
\text { (SO. IH.) }\end{array}$} & \multirow{2}{*}{$\begin{array}{l}\text { HOLE } 1 \\
\text { DIA } \\
\text { (IN) }\end{array}$} & \multirow{2}{*}{$\begin{array}{l}\text { HOLE } 2 \\
\text { DIA } \\
\text { (IN) }\end{array}$} & \multirow{2}{*}{$\begin{array}{l}\text { HOLE } 3 \\
\text { DIA } \\
\text { (IN) }\end{array}$} & \multicolumn{2}{|c|}{ CRATER I } & \multicolumn{2}{|c|}{ CRATER 2} & \multicolumn{2}{|c|}{ CRATER 3} \\
\hline & & & & & & & & & & & & $\begin{array}{l}\text { DIA } \\
\text { (IN) }\end{array}$ & $\begin{array}{l}\text { DEPIH } \\
\text { (IN) }\end{array}$ & $\begin{array}{l}\text { DIA } \\
\text { (IN) }\end{array}$ & $\begin{array}{c}\text { DEPTH } \\
\text { (IN) }\end{array}$ & $\begin{array}{l}\text { DIA } \\
\text { (IN) }\end{array}$ & $\begin{array}{r}\text { DEPTH } \\
\text { (IN) }\end{array}$ \\
\hline 960 & $2001-A$ & 0.353 & 0.353 & YES & 0.273 & 23.758 & No & & 0.172 & 0.212 & & 0.233 & 0.125 & 0.111 & 0.110 & 0.250 & 0.134 \\
\hline 962 & 2001-B & 0.350 & 0.350 & YES & 0.204 & 41.282 & YES & 0.035 & 0.121 & 0.164 & & 0.233 & 0.134 & 0.246 & 0.108 & 0.173 & 0.067 \\
\hline 961 & $2001-C$ & 0.377 & 0.377 & no & & 30.68 & YES & 0.010 & & & & 0.173 & 0.092 & 0.159 & 0.085 & 0.091 & 0.158 \\
\hline 929 & $2002-1$ & 0.503 & 0.503 & YES & 0.429 & 53.456 & YES & 0.153 & 0.218 & 0.229 & 0.180 & 0.179 & 0.119 & 0.201 & 0.132 & 0.192 & 0.129 \\
\hline 930 & $2002-B$ & 0.555 & 0.555 & YES & & 53.846 & YES & 0.026 & 0.122 & & & 0.156 & 0.105 & 0.170 & 0.094 & 0.145 & 0.107 \\
\hline 940 & $2002-c$ & 0.521 & 0.521 & YES & 0.288 & 27.155 & YES & 0.389 & 0.105 & 0.211 & 0.098 & 0.184 & 0.132 & 0.145 & 0.115 & 0.111 & 0.090 \\
\hline 949 & $2003-1$ & 0.542 & 0.542 & YES & 0.209 & 78.540 & YES & 0.24 & 0.130 & 0.098 & 0.085 & 0.255 & 0.133 & 0.121 & 0.082 & 0.170 & 0.120 \\
\hline 944 & 2003-B & 0.522 & 0.522 & YES & 0.296 & 70.882 & no & & 0.130 & 0.148 & 0.221 & 0.155 & 0.085 & 0.212 & 0.095 & 0.157 & 0.079 \\
\hline 945 & 2003-c & 0.544 & 0.544 & YES & 0.707 & 50.27 & no & & 0.707 & & & & & & & & \\
\hline 959 & 2003-A1 & 0.559 & 0.559 & NO & & 67.201 & no & & & & & 0.161 & 0.085 & 0.136 & 0.090 & 0.141 & 0.075 \\
\hline 956 & 2003-81 & 0.508 & 0.508 & YES & 0.556 & 60.132 & YES & 0.023 & 0.122 & 0.166 & 0.499 & 0.186 & 0.110 & 0.197 & 0.089 & 0.141 & 0.149 \\
\hline 941 & $2004-A$ & 0.542 & 0.542 & YES & 0.355 & 22.733 & YES & 0.570 & 0.106 & 0.301 & 0.122 & 0.173 & 0.096 & 0.163 & 0.060 & 0.128 & 0.070 \\
\hline 939 & 2004-8 & 0.546 & 0.546 & No & & 17.721 & YES & 0.494 & & & & 0.184 & 0.108 & 0.132 & 0.080 & 0.110 & 0.073 \\
\hline 931 & $2004-C$ & 0.514 & 0.514 & YES & 0.765 & 25.967 & YES & 0.029 & 0.765 & & & 0.181 & 0.075 & 0.173 & 0.097 & 0.134 & 0.068 \\
\hline
\end{tabular}




\begin{tabular}{|c|c|c|c|c|c|c|c|c|c|c|c|c|c|c|c|c|c|}
\hline \multirow[t]{2}{*}{ SHOT MO. } & \multirow[t]{2}{*}{ TEST KO. } & \multirow{2}{*}{$\begin{array}{l}\text { BUMPER PLATE } \\
\text { DMIN } \\
\text { (IN) }\end{array}$} & \multirow{2}{*}{$\begin{array}{l}\text { HOLE } \\
\text { DMAX } \\
\text { (IN) }\end{array}$} & \multirow{2}{*}{$\begin{array}{c}\text { BACKuALL } \\
\text { PERFoRAIED? }\end{array}$} & \multirow{2}{*}{$\begin{array}{l}\text { BACKHALL EO } \\
\text { HOLE DIAAEIER O) } \\
\text { (IM) }\end{array}$} & \multirow{2}{*}{$\begin{array}{l}\text { BACKUALL } \\
\text { OAMAGE AREA } \\
\text { (SO. III.) }\end{array}$} & \multirow[t]{2}{*}{$\begin{array}{l}\text { OACKMALL } \\
\text { SPALLEOT }\end{array}$} & \multirow{2}{*}{$\begin{array}{l}\text { BACKuALL } \\
\text { SPALL AREA } \\
\text { (SO. IM.) }\end{array}$} & \multirow{2}{*}{$\begin{array}{c}\text { HOLE }, \\
\text { DSA } \\
\text { (III) }\end{array}$} & \multirow{2}{*}{$\begin{array}{l}\text { MORMAL - } \\
\text { HOLE } 2 \\
\text { DIA } \\
\text { (IN) }\end{array}$} & \multirow{2}{*}{$\begin{array}{l}\text { HOLE } 3 \\
\text { DIA } \\
\text { (IW) }\end{array}$} & \multicolumn{2}{|c|}{ CRATER 1} & \multicolumn{2}{|c|}{ CRA ER 2} & \multicolumn{2}{|c|}{ CRATER 3} \\
\hline & & & & & & & & & & & & $\begin{array}{l}\text { DIA } \\
\text { (IM) }\end{array}$ & $\begin{array}{c}\text { DEPIK } \\
\text { (II) }\end{array}$ & $\begin{array}{l}\text { DIA } \\
\text { (1IN) }\end{array}$ & $\begin{array}{l}\text { DEPIH } \\
\text { (II) }\end{array}$ & $\begin{array}{l}\text { O1A } \\
\text { (III) }\end{array}$ & $\begin{array}{l}\text { DEPIH } \\
\text { (IK) }\end{array}$ \\
\hline 965 & 3001 & 0.328 & 0.39 & YES & 0.126 & 0.008 & no & & 0.126 & & & 0.068 & 0.042 & & & & \\
\hline 798 & $3001-A$ & 0.282 & 0.282 & YES & 0.384 & 3.98 & no & & 0.384 & & & 0.091 & 0.038 & 0.06 & 0.046 & 0.066 & 0.03 \\
\hline 799 & $3001-8$ & 0.334 & 0.334 & YES & 0.153 & 4.91 & No & & 0.153 & & & 0.11 & & 0.074 & 0.035 & 0.058 & 0.018 \\
\hline 800 & $3001-\mathrm{C}$ & 0.315 & 0.369 & YES & 0.176 & 1.72 & Mo & & 0.176 & & & 0.112 & 0.127 & $0.07 \pi$ & 0.029 & 0.105 & 0.019 \\
\hline 801 & $3009-0$ & 0.395 & 0.405 & no & & 0.196 & No & & 0.180 & 0.069 & 0.038 & 0.077 & 0.1 & 0.099 & 0.061 & 0.078 & 0.055 \\
\hline 802 & 3001-E & 0.32 & 0.345 & YES & 0.124 & 0.785 & No & & & & & 0.042 & 0.016 & 0.025 & 0.006 & & \\
\hline 803 & $3002-1$ & 0.463 & 0.463 & res & 1.0 & 2.41 & No & & $\begin{array}{r}0.124 \\
1.0\end{array}$ & & & 0.136 & 0.132 & 0.085 & 0.065 & 0.057 & 0.04 \\
\hline 804 & $3002-8$ & 0.385 & 0.385 & YES & 1.387 & 5.94 & no & & 1.0 & & & 0.081 & 0.06 & & & & \\
\hline 806 & 3002-C & 0.425 & 0.425 & no & & $1 . \pi$ & no & & 1.387 & 0.108 & & 0.061 & 0.021 & & & & \\
\hline 963 & 3003 & 0.397 & 0.442 & nо & & 3.142 & no & & & & & 0.128 & 0.09 & 0.081 & 0.027 & 0.065 & 0.019 \\
\hline 964 & 3004 & 0.38 & 0.539 & no & & 0.0 & no & & & & & 0.067 & 0.024 & 0.069 & 0.011 & 0.06 & 0.01 \\
\hline 807 & $3004-A$ & 0.355 & 0.431 & Ho & & 4.41 & nо & & & & & & & & & & \\
\hline 810 & $3004-8$ & 0.309 & 0.481 & No & & 1.23 & мо & & & & & 0.07 & 0.01 & & & & \\
\hline 808 & $3005-1$ & 0.67 & 0.614 & wo & & 0.196 & no & & & & & & $\begin{array}{l}0.002 \\
0.006\end{array}$ & 0.046 & 0.002 & & \\
\hline 811 & $3005-8$ & 0.461 & 0.636 & мо & & 1.767 & no & & & & & $\begin{array}{l}0.036 \\
0.071\end{array}$ & $\begin{array}{l}0.004 \\
0.019\end{array}$ & 0.031 & 0.006 & & \\
\hline 812 & $3006-1$ & 0.543 & 0.768 & wo & & 0.0 & мо & & & & & & & & & & \\
\hline 818 & $3007 \cdot 1$ & 0.408 & 0.882 & no & & 4.91 & мо & & & & & 0.115 & 0.031 & 0.082 & 0.03 & 0.093 & 0.03 \\
\hline 819 & $3007-8$ & 0.336 & 0.53 & No & & 4.91 & No & & & & & 0.103 & 0.052 & 0.106 & 0.024 & 0.081 & 0.009 \\
\hline 820 & $3007 \cdot c$ & 0.289 & 0.581 & no & & 19.635 & mo & & & & & 0.058 & 0.005 & & & & \\
\hline 821 & 3008-A & 0.431 & 0.862 & no & & 8.973 & no & & & & & 0.111 & 0.013 & 0.121 & 0.01 & 0.066 & 0.016 \\
\hline 822 & 3008-8 & 0.424 & 0.747 & wo & & 11.045 & mo & & & & & 0.088 & 0.019 & 0.065 & 0.012 & 0.098 & 0.011 \\
\hline 823 & $3009-1$ & 0.504 & 0.921 & Mo & & 8.301 & мо & & & & & 0.122 & 0.051 & 0.11 & 0.019 & 0.099 & 0.022 \\
\hline 824 & $3009 \cdot 8$ & 0.528 & 1.095 & mo & & 12.566 & мо & & & & & 0.098 & 0.03 & 0.078 & 0.015 & 0.118 & 0.09 \\
\hline 813 & $3010-A$ & 0.295 & 0.36 & YES & 0.122 & 3.53 & no & & 0.108 & 0.057 & & 0.112 & 0.086 & 0.108 & 0.062 & 0.075 & 0.035 \\
\hline 816 & $3010-8$ & 0.292 & 0.372 & YES & 0.153 & 2.087 & но & & 0.138 & 0.065 & & 0.062 & 0.082 & 0.067 & 0.053 & 0.065 & 0.066 \\
\hline 815 & $3010-c$ & 0.439 & 0.439 & YES & 0.068 & 1.767 & no & & 0.068 & & & 0.132 & 0.065 & 0.04 & 0.023 & 0.028 & 0.003 \\
\hline 816 & $3010-1-A$ & 0.508 & 0.508 & no & & 3.53 & No & & & & & 0.077 & 0.104 & 0.052 & 0.06 & 0.071 & 0.033 \\
\hline 817 & $3010-1.8$ & 0.429 & 0.456 & YES & 0.25 & 3.56 & мо & & 0.25 & & & 0.09 & 0.106 & 0.088 & 0.096 & 0.091 & 0.075 \\
\hline 826 & $3011-1$ & 0.524 & 0.524 & YES & 7.0 & 38.485 & no & & 7.0 & & & & & & & & \\
\hline 825 & $3011-8$ & 0.508 & 0.508 & YES & 7.5 & 44.89 & мо & & 7.5 & & & & & & & & \\
\hline 827 & $3012 \cdot 8$ & 0.289 & 0.327 & wo & & 3.563 & no & & & & & 0.115 & 0.004 & & & & \\
\hline 829 & $3012-c$ & 0.321 & 0.36 & mo & & 2.405 & no & & & & & 0.076 & 0.007 & 0.082 & 0.005 & 0.054 & 0.003 \\
\hline 828 & $3012-1$ & 0.327 & 0.369 & mo & & 2.53 & wo & & & & & 0.091 & 0.027 & 0.076 & 0.012 & 0.08 & 0.005 \\
\hline $\begin{array}{l}830 \\
831\end{array}$ & $\begin{array}{l}3013-A \\
3017-A\end{array}$ & $\begin{array}{l}0.426 \\
0.475\end{array}$ & $\begin{array}{l}0.478 \\
0.846\end{array}$ & $\omega_{0}^{0}$ & & & wo & & & & & 0.070 & 0.036 & & & & \\
\hline 832 & $3017-8$ & $\begin{array}{l}0.438 \\
0.436\end{array}$ & $\begin{array}{l}0.846 \\
0.796\end{array}$ & $\underset{\text { rES }}{\mathbf{N}}$ & 0.111 & 11.763 & wo & & & & & 0.21 & 0.07 & 0.115 & 0.031 & 0.097 & 0.03 \\
\hline 833 & $3017-\mathrm{c}$ & 0.456 & 0.808 & No & & $\begin{array}{r}9.621 \\
15.067\end{array}$ & no & & 0.111 & & & 0.097 & 0.04 & 0.108 & 0.036 & 0.088 & 0.029 \\
\hline 876 & $3019-1$ & 0.281 & 0.281 & YeS & 0.391 & $\begin{array}{l}15.067 \\
11.045\end{array}$ & no & & & & & 0.096 & 0.032 & 0.090 & 0.025 & 0.116 & 0.025 \\
\hline 877 & $3019 \cdot 8$ & 0.302 & 0.302 & * & & $\begin{array}{l}11.045 \\
25.428\end{array}$ & No & & 0.375 & 0.031 & & 0.146 & 0.031 & 0.131 & $0.0 \times 3$ & 0.067 & 0.016 \\
\hline 844 & $3020 \cdot A$ & 0.63 & 0.63 & YES & 8.16 & 63.62 & no & & 8.16 & & & 0.287 & 0.054 & 0.085 & 0.02 & 0.099 & 0.021 \\
\hline 834 & 3020.8 & 0.639 & 0.639 & YES & 7.12 & 39.76 & mo & & 7.12 & & & & & & & & \\
\hline
\end{tabular}




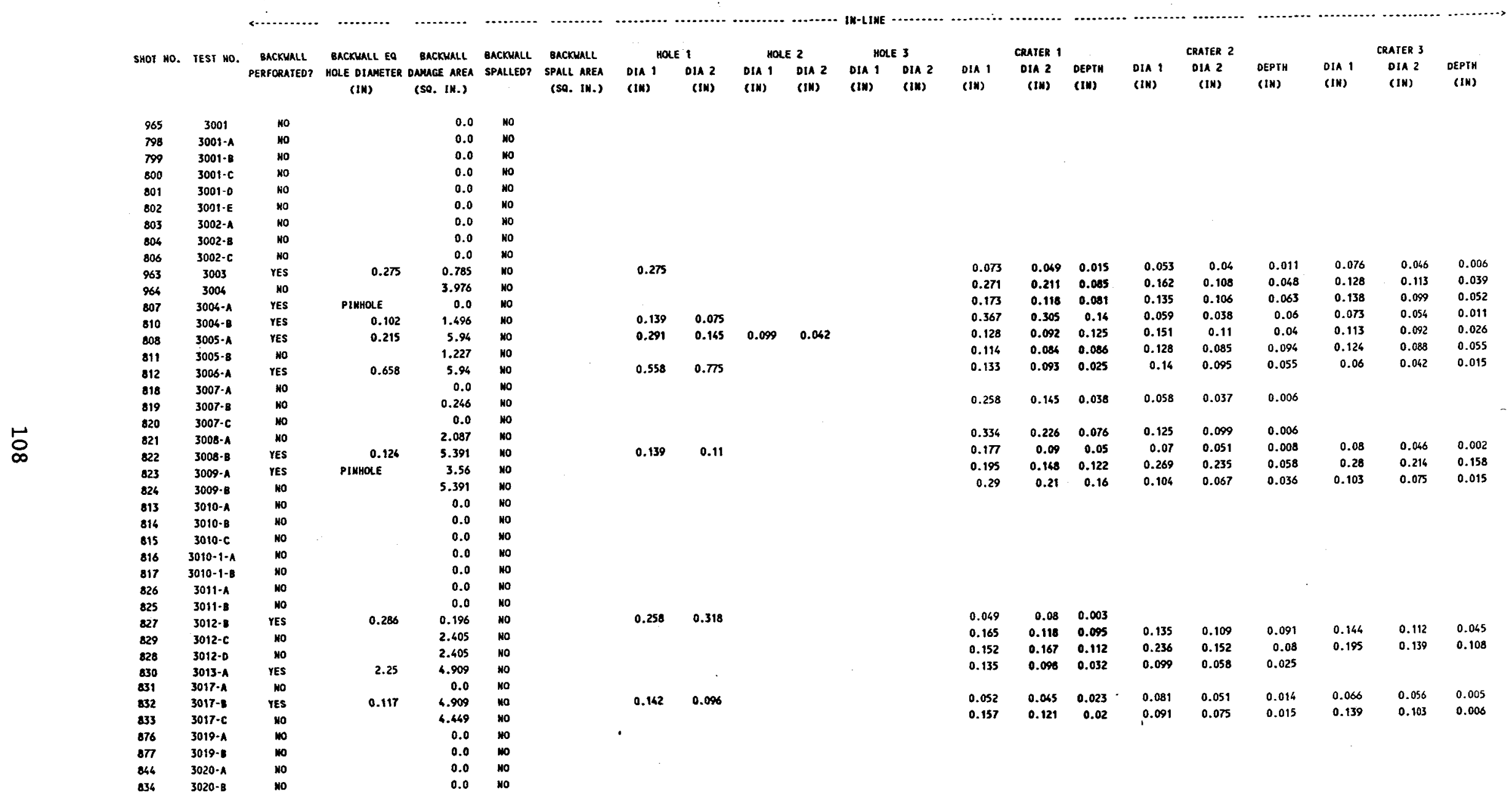

D3000SER.WK1 (Continued) 


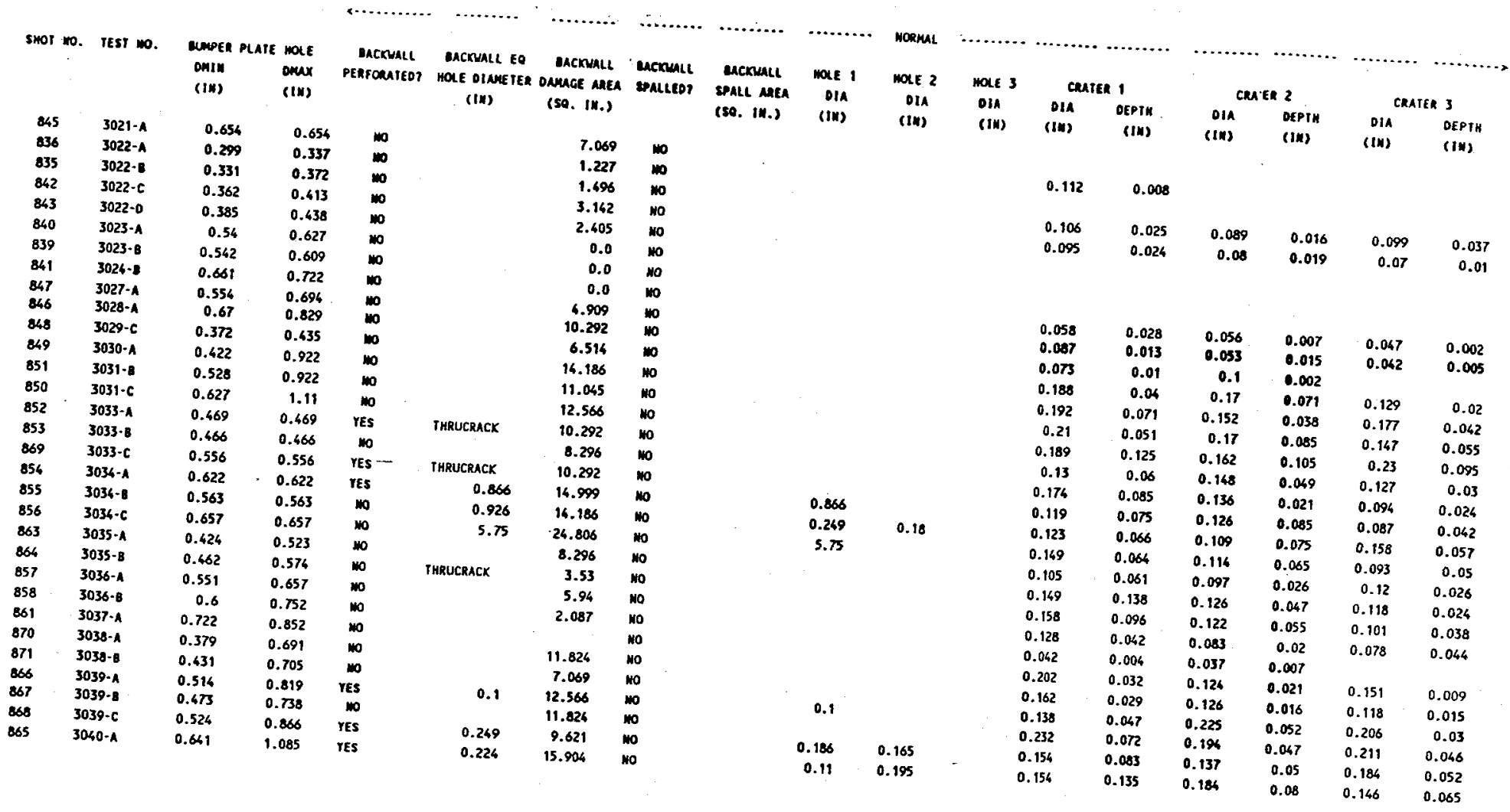

D3000SER.WKI (Continued) 


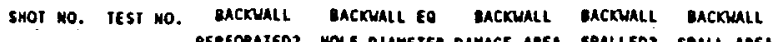

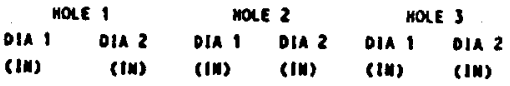

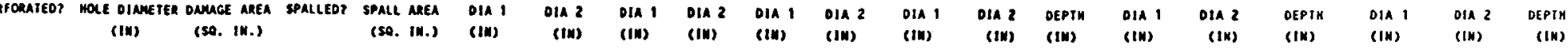

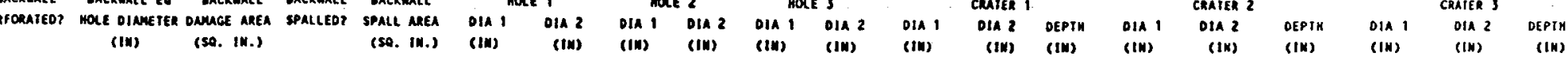

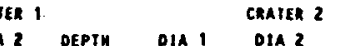

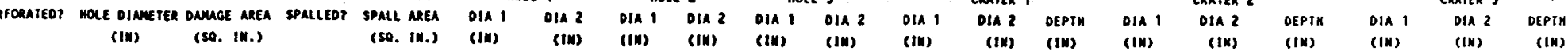

CaArer 3

\begin{tabular}{|c|c|c|c|c|}
\hline 845 & $3021-A$ & no & & 0.0 \\
\hline 036 & $3022-1$ & mo & & 1.003 \\
\hline 635 & $3022-8$ & no & & 2.405 \\
\hline$\alpha 2$ & $3022-c$ & YES & 0.232 & 2.087 \\
\hline$\alpha 3$ & 3022-D & res & 0.17 & 2.243 \\
\hline 840 & $3023-A$ & no & & 3.162 \\
\hline 839 & 3023-B & res & PIAHOLE/THRUCRA & 7.694 \\
\hline 841 & $3024-8$ & YES & 1.837 & 37.068 \\
\hline 847 & $3027-A$ & YES & 0.036 & 3.162 \\
\hline 868 & $3028-1$ & res & 1.2 & 6.469 \\
\hline 848 & $3029 \cdot c$ & No & & 2.405 \\
\hline 849 & $3030-A$ & mo & & 0.0 \\
\hline 851 & $3031-8$ & พo & & 0.108 \\
\hline 850 & $3031-\mathrm{c}$ & mo & & 7.686 \\
\hline 852 & 3033-A & мо & & 0.0 \\
\hline 853 & $3033-8$ & мо & & 0.0 \\
\hline 869 & $3033 \cdot c$ & mo & & 0.0 \\
\hline 856 & $3036-A$ & wo & & 0.0 \\
\hline 855 & $3036-1$ & no & & 0.0 \\
\hline 856 & $3036-c$ & No & & 0.0 \\
\hline 863 & $3035-A$ & res & 0.189 & 2.746 \\
\hline 264 & $3035-8$ & No & & 4.412 \\
\hline 857 & $3036-1$ & YES & 0.392 & 6.449 \\
\hline 858 & $3036-8$ & no & & 3.733 \\
\hline 861 & $3037-1$ & YES & 0.081 & 4.909 \\
\hline 870 & $3038-1$ & ผо & & 0.0 \\
\hline 871 & 3038-8 & HO & & 0.0 \\
\hline sss & $3038 \cdot-1$ & мо & & 0.0 \\
\hline 867 & 3039.1 & no & & 0.0 \\
\hline 868 & $3039-c$ & mo & & 0.0 \\
\hline 865 & $3060-1$ & no & & 0.0 \\
\hline
\end{tabular}

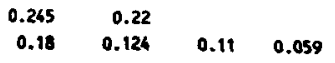

1.837

0.036
1.2

$0.212 \quad 0.169$

$\begin{array}{llll}0.339 & 0.369 & 0.17 & 0.17\end{array}$

$0.07 \quad 0.093$

$\begin{array}{ccccccccc}0.078 & 0.07 & 0.02 & 0.084 & 0.079 & 0.026 & 0.064 & 0.056 & 0.024 \\ 0.121 & 0.096 & 0.026 & 0.076 & 0.099 & 0.023 & 0.086 & 0.066 & 0.01 \\ 0.198 & 0.166 & 0.133 & 0.124 & 0.111 & 0.055 & 0.156 & 0.128 & 0.073 \\ 0.145 & 0.129 & 0.063 & 0.13 & 0.111 & 0.034 & 0.14 & 0.089 & 0.038 \\ 0.15 & 0.125 & 0.038 & 0.112 & 0.107 & 0.085 & 0.129 & 0.114 & 0.088\end{array}$

$\begin{array}{lllllllll}0.178 & 0.112 & 0.057 & 0.141 & 0.077 & 0.036 & 0.09 & 0.11 & 0.045 \\ 0.270 & 0.257 & 0.09 & 0.125 & 0.098 & 0.038 & 0.105 & 0.069 & 0.01 \\ 0.128 & 0.097 & 0.026 & 0.172 & 0.135 & 0.09 & 0.112 & 0.098 & 0.028 \\ 0.099 & 0.083 & 0.065 & 0.096 & 0.066 & 0.0421 & 0.101 & 0.079 & 0.046 \\ 0.142 & 0.119 & 0.075 & 0.078 & 0.11 & 0.065 & 0.131 & 0.106 & 0.123 \\ 0.256 & 0.202 & 0.14 & 0.186 & 0.167 & 0.105 & 0.139 & 0.11 & 0.069 \\ 0.165 & 0.099 & 0.056 & 0.088 & 0.068 & 0.039 & 0.156 & 0.116 & 0.067 \\ 0.163 & 0.137 & 0.101 & 0.155 & 0.128 & 0.063 & 0.165 & 0.135 & 0.107 \\ 0.255 & 0.2 & 0.075 & 0.133 & 0.109 & 0.032 & 0.208 & 0.123 & 0.104 \\ 0.158 & 0.129 & 0.068 & 0.113 & 0.107 & 0.026 & 0.09 & 0.112 & 0.043 \\ & & & & & & & & \\ 0.212 & 0.133 & 0.015 & & & & & & \\ 0.09 & 0.066 & 0.012 & 0.064 & 0.09 & 0.007 & 0.131 & 0.116 & 0.008\end{array}$

D3000SER.WK1 (Continued) 
SHOT NO. TEST NO.

BUMPER PLATE HOLE BACKHALL BACKHALL EQ BACKUALL BACKMALL.

DHIM. DMAX PERFORATED? HOLE DINMETER DAMAGE AREA SPALLED? BACKUALL HOLE 1

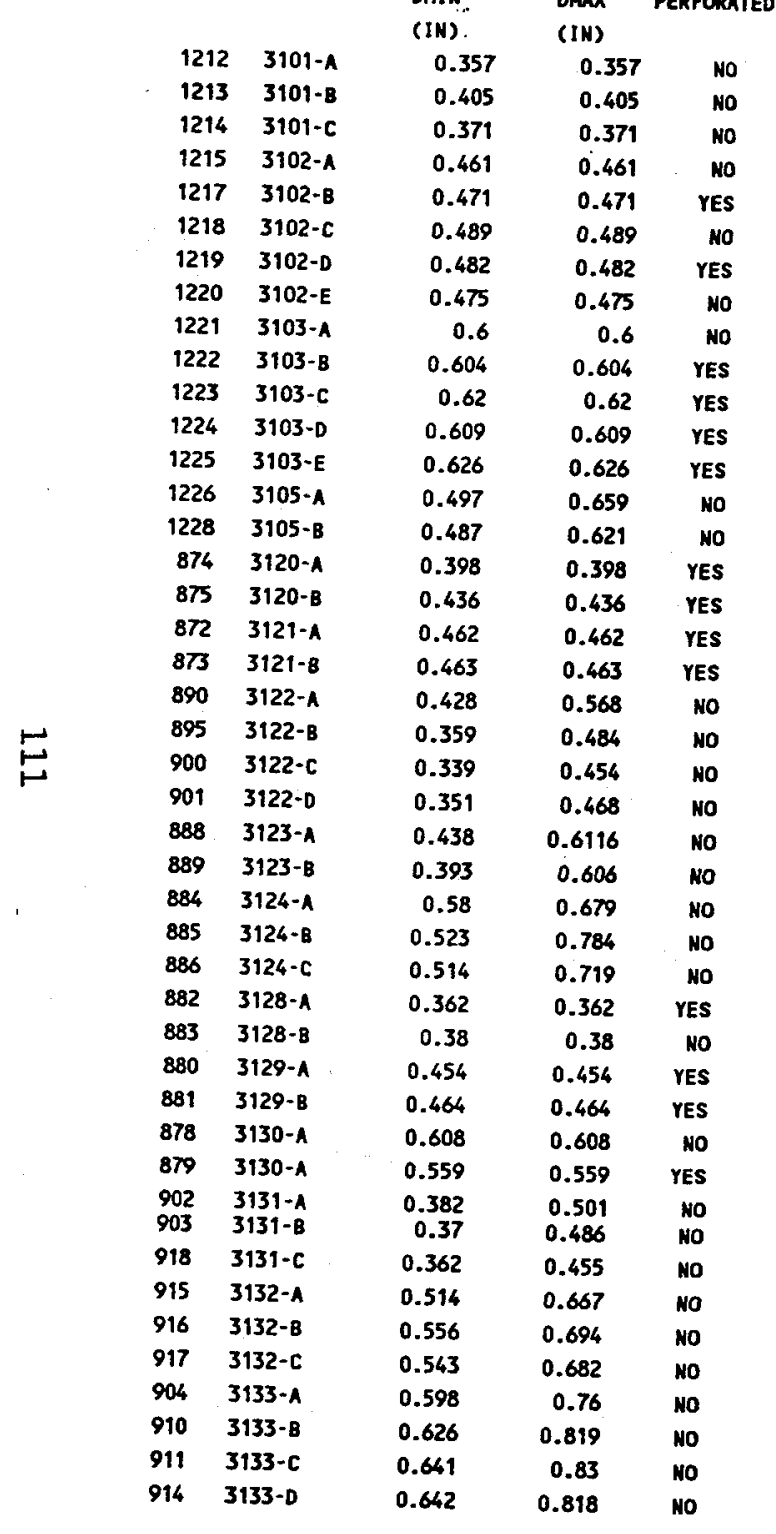

\begin{tabular}{|c|c|}
\hline (IN) & (sa. IN.) \\
\hline & 3.98 \\
\hline & 6.51 \\
\hline & 7.07 \\
\hline & 9.62 \\
\hline 0.176 & 4.41 \\
\hline & 7.69 \\
\hline 0.31 & 4.91 \\
\hline & 5.94 \\
\hline & 12.57 \\
\hline 0.186 & 12.57 \\
\hline 0.325 & 7.07 \\
\hline 0.237 & 7.07 \\
\hline THRUCRACK & 9.62 \\
\hline & 7.07 \\
\hline & 4.49 \\
\hline 0.228 & 16.403 \\
\hline 0.092 & 47.173 \\
\hline 0.089 & 33.183 \\
\hline 0.515 & 42.776 \\
\hline & 8.296 \\
\hline & 15.904 \\
\hline & 16.331 \\
\hline & 6.469 \\
\hline & 33.183 \\
\hline & 11.045 \\
\hline & 0 \\
\hline 0.204 & 37.828 \\
\hline & 38.485 \\
\hline 0.369 & 42.776 \\
\hline 0.268 & 39.815 \\
\hline & 67.201 \\
\hline 0.407 & 38.485 \\
\hline & $\begin{array}{l}54.367 \\
17.721\end{array}$ \\
\hline & 9.621 \\
\hline & 11.045 \\
\hline & 19.635 \\
\hline & 9.621 \\
\hline & 21.237 \\
\hline & 24.806 \\
\hline & 16.764 \\
\hline & 8.296 \\
\hline
\end{tabular}

HOLE 1 HOLE 2 HOLE 3 CRATER 1

$\begin{array}{lll}\text { (SO. IN.) } & \text { DIA } & \text { OIA }\end{array}$

ois

\begin{tabular}{llclccc} 
DIA & DEPTH & DIA & DEPTH & \multicolumn{2}{c}{ DIA } & DEPTH \\
(IN) & (IN) & (IN) & (IN) & (IN) & (IN) \\
0.206 & 0.143 & 0.196 & 0.125 & 0.163 & 0.045 \\
0.167 & 0.068 & 0.092 & 0.035 & 0.137 & 0.049
\end{tabular}

$\begin{array}{llllll}0.14 & 0.068 & 0.092 & 0.035 & 0.163 & 0.045 \\ 0.003 & 0.04 & 0.11 & 0.05 & 0.137 & 0.049\end{array}$

$0.603 \quad 0.163$

$\begin{array}{llllll}0.209 & 0.137 & 0.16 & 0.118 & 0.188 & 0.115\end{array}$

$0.38 \quad 0.194$

0.31

$0.49 \quad 0.186$

0.17 THRUCRACK

$0.48 \quad 0.237$

0.36

\begin{tabular}{|c|c|c|c|c|c|c|c|c|}
\hline 0.171 & 0.124 & 0.086 & 0.207 & 0.135 & 0.151 & 0.075 & 0.153 & 0.08 \\
\hline 0.092 & & & 0.11 & 0.055 & 0.078 & 0.051 & 0.09 & 0.02 \\
\hline 0.082 & 0.035 & & 0.141 & 0.065 & 0.168 & 0.077 & 0.146 & 0.063 \\
\hline \multirow[t]{7}{*}{0.431} & 0.201 & 0.162 & 0.162 & 0.093 & 0.145 & 0.075 & 0.129 & 0.111 \\
\hline & & & 0.11 & 0.029 & 0.088 & 0.023 & 0.041 & 0.003 \\
\hline & & & 0.148 & 0.037 & 0.118 & 0.044 & 0.11 & 0.029 \\
\hline & & & 0.147 & 0.048 & 0.104 & 0.049 & 0.106 & 0.034 \\
\hline & & & 0.062 & 0.024 & 0.055 & 0.019 & 0.035 & 0.005 \\
\hline & & & 0.107 & 0.052 & 0.094 & 0.032 & 0.073 & 0.018 \\
\hline & & & 0.093 & 0.009 & 0.074 & 0.005 & 0.034 & 0.001 \\
\hline \multirow[t]{2}{*}{0.204} & & & 0.104 & 0.015 & 0.181 & 0.052 & 0.112 & 0.04 \\
\hline & & & 0.155 & 0.099 & 0.126 & 0.025 & 0.094 & 0.026 \\
\hline 0.198 & 0.125 & 0.175 & 0.194 & 0.061 & 0.155 & 0.04 & 0.118 & 0.047 \\
\hline \multirow[t]{2}{*}{0.228} & 0.138 & 0.031 & 0.138 & 0.042 & 0.151 & 0.054 & 0.111 & 0.067 \\
\hline & & & 0.167 & 83 & 0.197 & 0.061 & 0.182 & 0.05 \\
\hline \multirow[t]{11}{*}{0.166} & 0.28 & 0.226 & 0.211 & 0.108 & 0.151 & 0.079 & 0.186 & 0.107 \\
\hline & & & 0.136 & 0.04 & 0.139 & 0.015 & 0.114 & 0.017 \\
\hline & & & 0.19 & 0.056 & 0.17 & 0.04 & 0.133 & 0.029 \\
\hline & & & 0.148 & 0.028 & 0.103 & 0.005 & 0.133 & 0.01 \\
\hline & & & 0.2 & 0.055 & 0.107 & 0.043 & 0.088 & 0.02 \\
\hline & & & 0.132 & 0.024 & 0.075 & 0.026 & 0.112 & 0.021 \\
\hline & & & 0.096 & 0.046 & 0.079 & 0.021 & 0.117 & 0.012 \\
\hline & & & 0.178 & 0.05 & 0.148 & 0.025 & 0.1 & 0.025 \\
\hline & & & 0.085 & 0.02 & 0.098 & 0.022 & 0.091 & 0.026 \\
\hline & & & 0.171 & 0.063 & 0.075 & 0.014 & 0.059 & 0.016 \\
\hline & & & 0.086 & 0.015 & 0.05 & 0.025 & 0.13 & 0.032 \\
\hline
\end{tabular}




\begin{tabular}{|c|c|c|c|c|c|c|c|c|c|c|c|c|c|c|c|c|c|c|c|c|c|}
\hline \multirow{2}{*}{ SHOT NO. } & \multirow{2}{*}{ TEST mo. } & \multirow{2}{*}{$\begin{array}{l}\text { BACKUALL } \\
\text { PERFORATED? }\end{array}$} & \multirow{2}{*}{$\begin{array}{l}\text { BACKHALL EQ } \\
\text { HOLE DINMETER } \\
\text { (IN) }\end{array}$} & \multirow{2}{*}{$\begin{array}{l}\text { DACKuALL } \\
\text { OAMAGE AREA } \\
\text { (SO. IH.) }\end{array}$} & \multirow{2}{*}{$\begin{array}{l}\text { BACKMALL } \\
\text { SPALLED? }\end{array}$} & \multirow{2}{*}{$\begin{array}{l}\text { BACKUALL } \\
\text { SPALL AREA } \\
\text { (SQ. IN.) }\end{array}$} & \multicolumn{2}{|c|}{ HOLE 1} & \multicolumn{2}{|c|}{ MOLE 2} & \multicolumn{2}{|c|}{ HOLE 3} & \multicolumn{3}{|c|}{ CRATER 1} & \multicolumn{3}{|c|}{ CRATER 2} & \multicolumn{3}{|c|}{ CRATER 3} \\
\hline & & & & & & & $\begin{array}{l}\text { orA } 1 \\
\text { (IN) }\end{array}$ & $\begin{array}{l}\text { DIA } 2 \\
\text { (III) }\end{array}$ & $\begin{array}{l}\text { DIA I } \\
\text { (IM) }\end{array}$ & $\begin{array}{l}\text { DIA } 2 \\
\text { (III) }\end{array}$ & $\begin{array}{l}\text { DIA I } \\
\text { (III) }\end{array}$ & $\begin{array}{l}\text { Dif } 2 \\
\text { (IM) }\end{array}$ & $\begin{array}{l}\text { DIA } 1 \\
\text { (III) }\end{array}$ & $\begin{array}{r}\text { olf } 2 \\
\text { (IN) }\end{array}$ & $\begin{array}{l}\text { DEPTH } \\
\text { (III) }\end{array}$ & $\begin{array}{l}\text { DIA } 1 \\
\text { (IN) }\end{array}$ & $\begin{array}{r}\text { DIA } 2 \\
\text { (IN) }\end{array}$ & $\begin{array}{l}\text { DEPTH } \\
\text { (IN) }\end{array}$ & $\begin{array}{l}\text { DIA } 1 \\
\text { (IN) }\end{array}$ & $\begin{array}{l}\text { DIA } 2 \\
\text { (IN) }\end{array}$ & $\begin{array}{l}\text { DEPTH } \\
\text { (IN) }\end{array}$ \\
\hline 1212 & $3101-A$ & & & & & & & & & & & & & & & & & & & & \\
\hline 1213 & $\begin{array}{l}3101-8 \\
3101-c\end{array}$ & & & & & & & & & & & & & & & & & & & & \\
\hline 1214 & $\begin{array}{l}3101-C \\
3102-A\end{array}$ & & & & & & & & & & & & & & & & & & & & \\
\hline $\begin{array}{l}1215 \\
1217\end{array}$ & $\begin{array}{l}3102-1 \\
3102-8\end{array}$ & & & & & & & & & & & & & & & & & & & & \\
\hline $\begin{array}{l}1217 \\
1218\end{array}$ & $\begin{array}{l}3102-8 \\
3102-C\end{array}$ & & & & & & & & & & & & & & & & & & & & \\
\hline $\begin{array}{l}1218 \\
1219\end{array}$ & $\begin{array}{l}3102-C \\
3102-D\end{array}$ & & & & & & & & & & & & & & & & & & & & \\
\hline $\begin{array}{l}1219 \\
1220\end{array}$ & 3102-E & & & & & & & & & & & & & & & & & & & & \\
\hline 1221 & $3103-1$ & & & & & & & & & & & & & & & & & & & & \\
\hline 1222 & 3103-8 & & & & & & & & & & & & & & & & & & & & \\
\hline 1223 & $3103-c$ & & & & & & & & & & & & & & & & & & & & \\
\hline 1224 & 3103-0 & & & & & & & & & & & & & & & & & & & & \\
\hline $\begin{array}{l}1225 \\
1226\end{array}$ & $\begin{array}{l}\text { 3103-E } \\
3105-\AA\end{array}$ & mo & & 3.14 & no & & & & & & & & 0.336 & 0.259 & 0.137 & 0.321 & 0.226 & 0.176 & 0.289 & 0.298 & 0.136 \\
\hline 1228 & 3105-8 & no & & 2.41 & no & & & & & & & & 0.285 & 0.285 & 0.078 & 0.18 & 0.18 & 0.053 & 0.238 & 0.238 & 0.072 \\
\hline 874 & $3120-1$ & & & & & & & & & & & & & & & & & & & & \\
\hline 875 & $3120-8$ & & & & & & & & & & & & & & & & & & & & \\
\hline 872 & $3121-1$ & & & & & & & & & & & & & & & & & & & & \\
\hline 873 & $3121-8$ & MO & & 6.514 & No & & & & & & & & 0.141 & 0.134 & 0.025 & 0.053 & 0.033 & 0.002 & & & \\
\hline $\begin{array}{l}890 \\
895\end{array}$ & $\begin{array}{l}3122-\lambda \\
3122-8\end{array}$ & Mo & & 39.927 & No & & & & & & & & 0.18 & 0.137 & 0.048 & 0.212 & 0.16 & 0.04 & 0.12 & 0.07 & 0.057 \\
\hline 900 & $3122-c$ & YES & 0.289 & 5.147 & No & & 0.301 & $0.2 \pi$ & & & & & 0.211 & 0.108 & 0.011 & 0.246 & 0.115 & 0.029 & 0.192 & 0.154 & 0.048 \\
\hline 901 & $3122-0$ & no & & 0.694 & nO & & & & & & & & 0.218 & 0.138 & 0.065 & 0.184 & 0.115 & 0.059 & 0.28 & 0.186 & 0.048 \\
\hline 888 & $3123-1$ & YES & 0.331 & 47.173 & NO & & 0.376 & 0.291 & & & & & 0.387 & 0.227 & 0.121 & 0.212 & 0.224 & 0.087 & 0.273 & 0.196 & 0.055 \\
\hline 889 & 3123.8 & YES & 0.235 & 37.068 & no & & 0.255 & 0.179 & 0.108 & 0.088 & & & 0.235 & 0.161 & 0.117 & 0.22 & 0.193 & 0.047 & 0.197 & 0.095 & 0.053 \\
\hline 824 & $3124-1$ & YES & 0.718 & 19.635 & No & & 0.693 & 0.744 & & & & & 0.124 & 0.11 & 0.034 & 0.289 & 0.213 & 0.095 & 0.224 & 0.212 & 0.12 \\
\hline 885 & 3124-8 & YES & 0.674 & 17.721 & HO & , & 0.368 & 0.298 & 0.611 & 0.682 & 0.261 & 0.201 & 0.2 & 0.159 & 0.065 & 0.176 & 0.143 & 0.108 & 0.177 & 0.16 & 0.087 \\
\hline 886 & $3124-c$ & YES & 0.66 & 13.332 & No & & 0.181 & 0.077 & 0.255 & 0.136 & 0.159 & 0.126 & 0.165 & 0.122 & 0.07 & 0.229 & 0.112 & 0.042 & 0.144 & 0.087 & 0.035 \\
\hline 882 & $3128-1$ & & & & & & & & & & & & & & & & & & & & \\
\hline 883 & 3128-8 & & & & & & & & & & & & & & & & & & & & \\
\hline 880 & $3120-1$ & & & & & & & & & & & & & & & & & & & & \\
\hline 881 & $\begin{array}{l}3129-8 \\
3130-8\end{array}$ & & & & & & & & & & & & & & & & & & & & \\
\hline $\begin{array}{l}878 \\
879\end{array}$ & $\begin{array}{l}3130-A \\
3130-A\end{array}$ & & & & & & & & & & & & & & & & & & & & \\
\hline 902 & $3131-A$ & $\begin{array}{l}\text { No } \\
\text { No }\end{array}$ & & $\begin{array}{l}9.621 \\
4.909\end{array}$ & $\begin{array}{l}\text { No } \\
\text { Ho }\end{array}$ & & & & & & & & 0.358 & 0.204 & 0.055 & & & & & & \\
\hline $\begin{array}{l}903 \\
918\end{array}$ & $\begin{array}{l}3131-8 \\
3131-\mathrm{C}\end{array}$ & No & & 9.624 & $\begin{array}{l}\text { No } \\
\text { no }\end{array}$ & & & & & & & & 0.306 & 0.347 & 0.11 & 0.125 & 0.075 & 0.011 & 0.115 & 0.091 & 0.015 \\
\hline 918 & $\begin{array}{l}3131-c \\
3132-A\end{array}$ & YES & 0.234 & 33.183 & NO & & & & & & & & 0.338 & 0.284 & 0.039 & 0.193 & 0.122 & 0.007 & 0.129 & 0.087 & 0.003 \\
\hline 915 & $3132-A$ & & & $\begin{array}{r}33.00 \\
7.645\end{array}$ & $\begin{array}{l}\text { No } \\
\text { nO }\end{array}$ & & 0.237 & 0.231 & & & & & 0.208 & 0.189 & 0.086 & 0.279 & 0.198 & 0.042 & 0.254 & 0.189 & 0.064 \\
\hline & & & & 44.179 & No & & 0.149 & 0.12 & . & & & & 0.241 & 0.279 & 0.11 & 0.227 & 0.212 & 0.105 & 0.175 & 0.268 & 0.126 \\
\hline 904 & $3133-A$ & YES & 0.636 & 38.485 & NO & & 0.367 & 0.206 & 0.429 & 0.275 & 0.412 & 0.3 & 0.245 & 0.176 & 0.055 & 0213 & 0.16 & 0.053 & 0.206 & 0.261 & 0.109 \\
\hline 910 & $3133-8$ & YES & 0.297 & 22.732 & No & & 0.107 & 0.098 & 0.286 & 0.271 & & & 0.236 & 0.18 & 0.071 & $0.2+8$ & m & 0.076 & 0.194 & 0.151 & 0.075 \\
\hline 911 & $3133-c$ & YES & 0.422 & 11.045 & no & & 0.261 & 0.31 & 0.18 & 0.252 & 0.25 & 0.208 & 0.242 & 0.203 & 0.076 & 0.522 & b. & 0.098 & 0.206 & 0.12 & 0.031 \\
\hline 914 & $3133-0$ & YES & 0.518 & 38.485 & no & & 0.105 & 0.071 & 0.358 & 0.628 & 0.205 & 0.174 & 0.188 & 0.208 & 0.08 & 0.238 & 0.196 & 0.065 & 0.282 & 0.211 & 0.128 \\
\hline
\end{tabular}


SHOT NO. TEST NO.

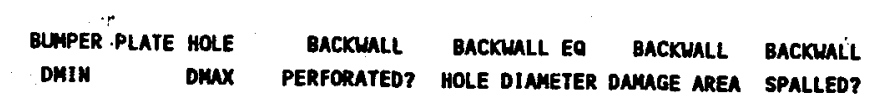

$\begin{array}{ccccc}\text { QACKUALL } & \text { HOLE 1 } & \text { HOLE } 2 & \text { HOLE } 3 & \text { CRATER } 1 \\ \text { SPALL AREA DIA } & \text { DIA } & \text { DIA } & \text { DIA DEP }\end{array}$

(IN) (SO. IN.)

(SO. IN.)

(II)

(IN)

(IN) (IN) DEPTH
(III)

CRATER 2

CRATER 3

$\begin{array}{ccc}0.424 & 0.424 & \text { NO } \\ 0.682 & 0.682 & \text { YES } \\ 0.637 & 0.637 & \text { YES } \\ 0.724 & 0.724 & \text { YES } \\ 0.489 & 0.489 & \text { NO } \\ 0.54 & 0.54 & \text { YES } \\ 0.442 & 0.552 & \text { NO } \\ 0.387 & 0.777 & \text { NO } \\ 0.451 & 0.798 & \text { NO } \\ 0.44 & 0.873 & \text { NO } \\ 0.448 & 0.982 & \text { NO } \\ 0.46 & 0.797 & \text { NO } \\ 0.492 & 0.922 & \text { NO } \\ 0.505 & 1.018 & \text { NO } \\ 0.512 & 1.047 & \text { NO } \\ 0.513 & 0.978 & \text { NO } \\ 0.575 & 1.06 & \text { NO } \\ 0.568 & 1.033 & \text { NO } \\ 0.548 & 1.057 & \text { NO } \\ 0.55 & 1.101 & \text { NO } \\ 0.474 & 0.474 & \text { YES } \\ 0.466 & 0.466 & \text { YES } \\ 0.386 & 0.386 & \text { YES } \\ 0.381 & 0.381 & \text { YES } \\ 0.308 & 0.308 & \text { YES } \\ 0.595 & 0.595 & \text { NO } \\ 0.486 & 0.486 & \text { YES } \\ 0.521 & 0.521 & \text { NO } \\ 0.493 & 0.493 & \text { YES } \\ 0.483 & 0.483 & \text { YES } \\ 0.587 & 0.587 & \text { NO } \\ 0.618 & 0.618 & \text { YES } \\ 0.638 & 0.638 & \text { YES } \\ 0.638 & 0.638 & \text { NO } \\ 0.696 & 0.696 & \text { YES } \\ 0.645 & 0.645 & \text { YES } \\ 0.654 & 0.656 & \text { NO } \\ 0.674 & 0.674 & \text { YES } \\ & & \end{array}$

\begin{tabular}{|c|c|c|}
\hline & 4.909 & \\
\hline 0.298 & 3.14 & \\
\hline 0.51 & 8.29 & \\
\hline \multirow[t]{2}{*}{0.506} & 9.62 & \\
\hline & 7.645 & \\
\hline \multirow[t]{15}{*}{0.236} & 3.142 & \\
\hline & 0.785 & \\
\hline & 9.621 & \\
\hline & 11.763 & \\
\hline & 9.621 & \\
\hline & 5.94 & \\
\hline & 22.648 & \\
\hline & 17.721 & \\
\hline & 9.621 & \\
\hline & 13.396 & \\
\hline & 9.621 & \\
\hline & 11.824 & \\
\hline & 5.433 & \\
\hline & 4.909 & \\
\hline & 3.53 & \\
\hline 0.073 & 30.68 & \\
\hline 0.23 & 29.513 & $\pi$ \\
\hline 0.336 & 8.973 & \\
\hline 0.299 & 12.566 & \\
\hline \multirow[t]{2}{*}{0.111} & 17.721 & w \\
\hline & 45.723 & w \\
\hline \multirow[t]{2}{*}{0.115} & 47.173 & Y \\
\hline & 41.282 & NC \\
\hline 7.79 & 88.748 & $N$ \\
\hline \multirow[t]{2}{*}{6.63} & 34.524 & no \\
\hline & 54.19 & NC \\
\hline 0.187 & 88.581 & r \\
\hline \multirow[t]{2}{*}{0.624} & 35.785 & we \\
\hline & 48.769 & YE \\
\hline 8.5 & 88.748 & No \\
\hline \multirow[t]{2}{*}{3.742} & 48.645 & No \\
\hline & 51.912 & NO \\
\hline 2.387 & 11.045 & NO \\
\hline
\end{tabular}

\begin{tabular}{|c|c|c|c|c|c|c|c|c|c|}
\hline & 0.298 & & & 0.032 & 0.003 & & & & \\
\hline & $\begin{array}{l}0.806 \\
0.506\end{array}$ & & & 0.056 & 0.05 & 0.096 & 0.034 & 0.082 & 0.032 \\
\hline & & & & 0.069 & 0.025 & 0.048 & 0.014 & 0.082 & 0.034 \\
\hline & 0.183 & 0.081 & 0.097 & 0.129 & 0.064 & 0.077 & 0.065 & 0.091 & 0.035 \\
\hline & & & & 0.13 & 0.035 & 0.059 & 0.004 & 0.075 & 0.021 \\
\hline & & & & 0.07 & 0.005 & 0.104 & 0.008 & 0.125 & 0.004 \\
\hline & & & & 0.166 & 0.058 & 0.117 & 0.042 & 0.107 & 0.05 \\
\hline & & & & 0.126 & 0.035 & 0.228 & 0.06 & 0.133 & 0.033 \\
\hline & & & & 0.149 & 0.03 & 0.125 & 0.033 & 0.105 & 0.014 \\
\hline & & & & 0.105 & 0.026 & 0.152 & 0.027 & 0.163 & 0.025 \\
\hline & & & & 0.157 & 0.032 & 0.16 & 0.027 & 0.205 & 0.025 \\
\hline & & & & 0.115 & 0.047 & 0.123 & 0.036 & 0.134 & 0.008 \\
\hline & & & & 0.147 & 0.075 & 0.162 & 0.067 & 0.165 & 0.038 \\
\hline & & & & 0.171 & 0.082 & 0.122 & 0.059 & 0.159 & 0.055 \\
\hline & & & & 0.162 & 0.096 & 0.187 & 0.065 & 0.111 & 0.088 \\
\hline & & & & 0.254 & 0.125 & 0.155 & 0.065 & 0.132 & 0.062 \\
\hline & & & & 0.178 & 0.134 & 0.155 & 0.048 & 0.158 & 0.056 \\
\hline & & & & 0.183 & 0.045 & 0.154 & 0.056 & 0.186 & 0.05 \\
\hline 0.008 & 0.066 & 0.031 & & 0.153 & 0.077 & 0.13 & 0.106 & 0.149 & 0.076 \\
\hline & 0.161 & 0.144 & 0.078 & 0.141 & 0.063 & 0.113 & 0.073 & 0.103 & 0.062 \\
\hline 0.052 & 0.064 & 0.183 & 0.24 & 0.126 & 0.065 & 0.171 & 0.104 & 0.205 & 0.085 \\
\hline & 0.094 & 0.16 & 0.108 & 0.188 & 0.077 & 0.2 & 0.136 & 0.09 & 0.05 \\
\hline & 0.111 & & & 0.113 & 0.053 & 0.124 & 0.055 & 0.156 & 0.05 \\
\hline & & & & 0.175 & 0.07 & 0.119 & 0.058 & 0.153 & 0.042 \\
\hline 0.007 & 0.115 & & & 0.199 & 0.1 & 0.181 & 0.067 & 0.16 & 0.063 \\
\hline & & & & 0.099 & 0.039 & 0.13 & 0.037 & 0.137 & 0.032 \\
\hline & 7.79 & & & 0.11 & 0.053 & 0.138 & 0.065 & 0.196 & 0.056 \\
\hline & 6.63 & & & 0.221 & 0.0085 & 0.1177 & 0.082 & 0.139 & 0.069 \\
\hline & & & & 0.157 & 0.124 & 0.063 & 0.055 & 0.064 & 0.026 \\
\hline 0.089 & 0.11 & 0.12 & 0.092 & 0.18 & 0.126 & 0.152 & 0.061 & 0.259 & 0.13 \\
\hline & 0.24 & 0.281 & 0.425 & 0.173 & 0.125 & 0.157 & 0.066 & 0.17 & 0.075 \\
\hline 0.006 & & & & 0.178 & 0.052 & 0.226 & 0.077 & 0.157 & 0.063 \\
\hline & 8.5 & & & 0.148 & 0.072 & 0.16 & 0.065 & 0.1 & 0.086 \\
\hline & 3.742 & & & & & & & & \\
\hline & & & & 0.147 & 0.045 & 0.166 & 0.075 & 0.134 & 0.096 \\
\hline & 2.382 & 0.149 & & 0.132 & 0.037 & 0.125 & 0.06 & 0.188 & 0.059 \\
\hline
\end{tabular}




\begin{tabular}{|c|c|c|c|c|c|c|c|c|}
\hline \multirow{2}{*}{ SHOT No. } & \multirow{2}{*}{ TEST MO. } & \multirow{2}{*}{$\begin{array}{l}\text { BACKMALL } \\
\text { PERFORATED? }\end{array}$} & \multirow{2}{*}{$\begin{array}{l}\text { BACKHALL EQ } \\
\text { HOLE DINMETER } \\
\text { (IN) }\end{array}$} & \multirow{2}{*}{$\begin{array}{l}\text { BACKMALL } \\
\text { DAMAGE AREA } \\
\text { (SQ. IH.) }\end{array}$} & \multirow{2}{*}{$\begin{array}{l}\text { BACKUALL } \\
\text { SPALLED? }\end{array}$} & \multirow{2}{*}{$\begin{array}{l}\text { BACKUALL } \\
\text { SPALL AREA } \\
\text { (SQ. IN.) }\end{array}$} & \multicolumn{2}{|c|}{ HOLE 1} \\
\hline & & & & & & & $\begin{array}{l}\text { DIA } 1 \\
\text { (II) }\end{array}$ & $\begin{array}{l}\text { DIA } 2 \\
\text { (IM) }\end{array}$ \\
\hline 966 & 3202 & & & & & & & \\
\hline 1010 & $3202-1$ & & & & & & & \\
\hline 1011 & $3202-8$ & & & & & & & \\
\hline 1012 & $3202-c$ & & & & & & & \\
\hline 967 & 3205 & & & & & & & \\
\hline 969 & 3206 & & & & & & & \\
\hline 970 & 3207 & YES & 0.453 & 2.747 & No & & 0.512 & 0.4 \\
\hline 971 & 3208 & nо & & 1.227 & No & & & \\
\hline 972 & 3200 & NO & & 2.061 & NO & & & \\
\hline 983 & $3209-1$ & NO & & 11.763 & NO & & & \\
\hline 974 & 3210 & No & & 7.645 & NO & & & \\
\hline 973 & 3211 & мо & & 0.302 & Ho & & & \\
\hline 975 & 3212 & VES & 0.161 & 0.705 & No & & 0.151 & 0.172 \\
\hline 982 & $3212-1$ & YES & 0.28 & 2.405 & no & & 0.263 & 0.276 \\
\hline 976 & 3213 & No & & 3.53 & wo & & & \\
\hline 977 & 3216 & No & & 0.642 & mo & & & \\
\hline 978 & 3215 & No & & 5.931 & No & & & \\
\hline 980 & 3216 & NO & & 3.976 & YES & 0.016 & & \\
\hline 979 & 3217 & NO & & 3.976 & No & & & \\
\hline 981 & 3218 & No & & 2.405 & NO & & & \\
\hline 984 & $3220-A$ & & & & & & & \\
\hline 985 & $3220-8$ & & & & & & & \\
\hline 986 & $3221-1$ & & & & & & & \\
\hline 987 & $3221-8$ & & & & & & & \\
\hline 988 & $3222-1$ & & & & & & & \\
\hline 991 & $3223-1$ & & & & & & & \\
\hline 990 & $3226-A$ & & & & & & & \\
\hline 989 & $3226-8$ & & & & & & & \\
\hline 992 & 3225 & & & & & & & \\
\hline 993 & $3225-1$ & & & & & & & \\
\hline 1009 & $3225-\mathrm{C}$ & & & & & & & \\
\hline 895 & $3226-A$ & & & & & & & \\
\hline 996 & $3226-8$ & & & & & & & \\
\hline $\begin{array}{l}996 \\
997\end{array}$ & $\begin{array}{l}3226-C \\
3227-A\end{array}$ & & & & & & & \\
\hline 1002 & $3227-8$ & & & & & & & \\
\hline 996 & $3227-\mathrm{C}$ & & & & & & & \\
\hline 1000 & $3227-D$ & & & & & & & \\
\hline
\end{tabular}

\begin{tabular}{|c|c|c|c|c|c|c|c|c|c|c|}
\hline \multicolumn{2}{|c|}{ HOLE 3} & \multicolumn{3}{|c|}{ CRATER 1} & \multicolumn{3}{|c|}{ CRATER 2} & \multicolumn{3}{|c|}{ CRATER 3} \\
\hline $\begin{array}{l}\text { In I } \\
\text { IM) }\end{array}$ & $\begin{array}{l}\text { DiA } 2 \\
\text { (II) }\end{array}$ & $\begin{array}{l}\text { DIA } 1 \\
\text { (IN) }\end{array}$ & $\begin{array}{l}\text { DIA } 2 \\
\text { (II) }\end{array}$ & $\begin{array}{l}\text { DEPIH } \\
\text { (IN) }\end{array}$ & $\begin{array}{l}\text { DIA } 1 \\
\text { (IN) }\end{array}$ & $\begin{array}{r}\text { DIA } 2 \\
\text { (IN) }\end{array}$ & $\begin{array}{l}\text { DEPTH } \\
\text { (IN) }\end{array}$ & $\begin{array}{l}\text { DIA } 1 \\
\text { (IH) }\end{array}$ & $\begin{array}{l}\text { DIA } 2 \\
\text { (IN) }\end{array}$ & $\begin{array}{l}\text { DEPTH } \\
\text { (IN) }\end{array}$ \\
\hline
\end{tabular}

(IN)

(IH)

(IN)

(II)

$\begin{array}{rrrrrrrrr}0.111 & 0.102 & 0.038 & 0.149 & 0.1 & 0.03 & 0.175 & 0.092 & 0.08 \\ 0.232 & 0.181 & 0.017 & 0.322 & 0.22 & 0.01 & & & \\ 0.172 & 0.16 & 0.027 & 0.17 & 0.096 & 0.013 & & & \\ 0.164 & 0.153 & 0.029 & 0.238 & 0.145 & 0.02 & & & \\ 0.174 & 0.161 & 0.034 & 0.186 & 0.133 & 0.039 & 0.15 & 0.127 & 0.045 \\ & & & & & & & & \\ 0.145 & 0.074 & 0.023 & & & & & & \\ 0.175 & 0.126 & 0.01 & 0.175 & 0.119 & 0.008 & 0.081 & 0.052 & 0.01 \\ 0.49 & 0.3 & 0.094 & 0.266 & 0.229 & 0.07 & 0.205 & 0.128 & 0.045 \\ 0.394 & 0.236 & 0.068 & 0.228 & 0.142 & 0.035 & & & \\ 0.356 & 0.238 & 0.105 & 0.116 & 0.079 & 0.044 & 0.147 & 0.124 & 0.058 \\ 0.321 & 0.232 & 0.08 & 0.14 & 0.096 & 0.025 & 0.132 & 0.09 & 0.028 \\ 0.227 & 0.192 & 0.054 & 0.242 & 0.144 & 0.057 & 0.27 & 0.148 & 0.056 \\ 0.298 & 0.177 & 0.041 & 0.18 & 0.152 & 0.03 & 0.162 & 0.109 & 0.025\end{array}$

D3200SER.WK1 (Continued) 


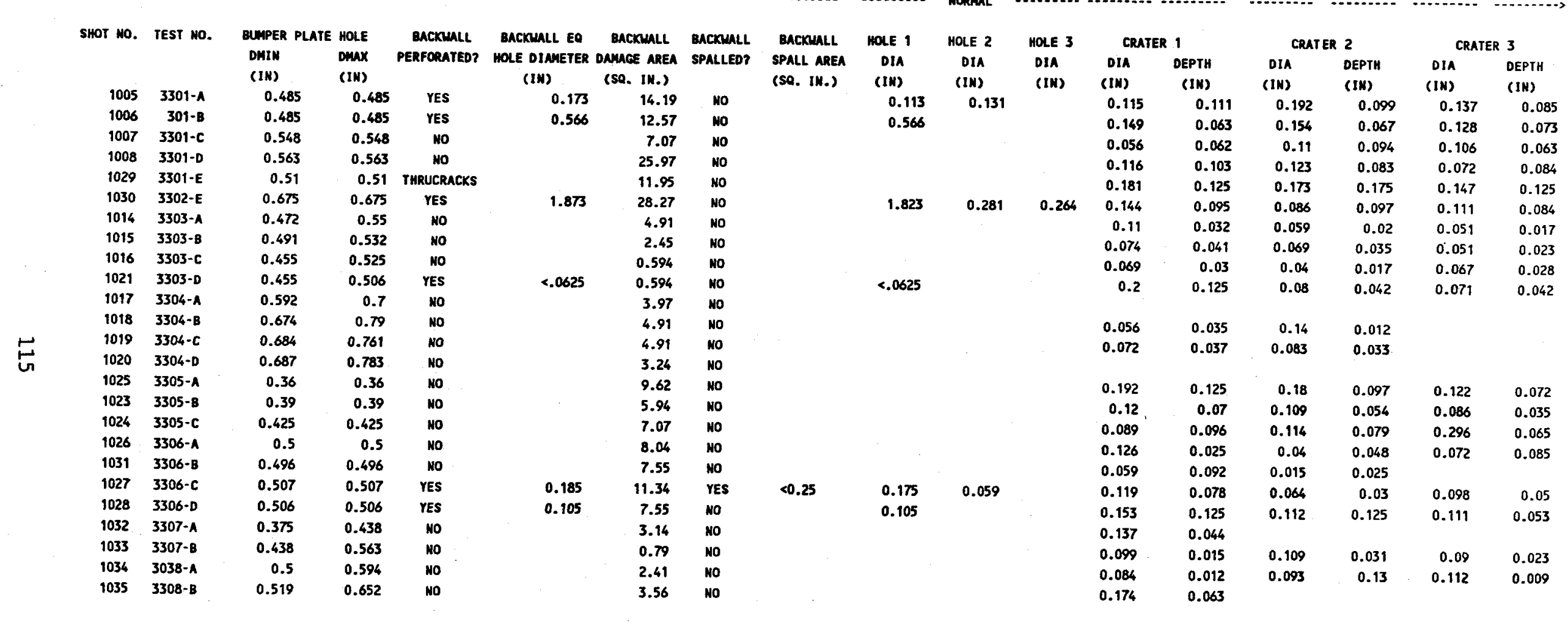




\begin{tabular}{|c|c|c|c|c|c|c|c|c|c|c|c|c|c|c|c|c|c|c|c|c|c|}
\hline \multirow{2}{*}{ smor мо. } & \multirow{2}{*}{ TEST MO. } & \multirow{2}{*}{$\begin{array}{l}\text { BaCRuALL } \\
\text { PERForatedo? }\end{array}$} & \multirow{2}{*}{$\begin{array}{l}\text { BACKUALL EO } \\
\text { HOLE DIAMETER } \\
\text { (IN) }\end{array}$} & \multirow{2}{*}{$\begin{array}{c}\text { BACKLALL } \\
\text { DAMUCE AREA } \\
\text { (SO. IN.) }\end{array}$} & \multirow{2}{*}{$\begin{array}{l}\text { BACKMALL } \\
\text { SPALLED? }\end{array}$} & \multirow{2}{*}{$\begin{array}{l}\text { BACKWHLL } \\
\text { SPALL AREA } \\
\text { (SO. IH.) }\end{array}$} & \multicolumn{2}{|c|}{ HOLE 1} & \multicolumn{2}{|c|}{ HOLE 2} & \multicolumn{2}{|c|}{ HOLE 3} & \multicolumn{3}{|c|}{ CRATER 1} & \multicolumn{3}{|c|}{ CRATER 2} & \multicolumn{3}{|c|}{ CRATER 3} \\
\hline & & & & & & & $\begin{array}{l}\text { OIA } 1 \\
\text { (IN) }\end{array}$ & $\begin{array}{r}\text { DIA } 2 \\
\text { (IN) }\end{array}$ & $\begin{array}{l}\text { DIA I } \\
\text { (IB) }\end{array}$ & $\begin{array}{l}\text { DIA } 2 \\
\text { (IM) }\end{array}$ & $\begin{array}{l}\text { DIA } 1 \\
\text { (II) }\end{array}$ & $\begin{array}{l}\text { DIA } 2 \\
\text { (IN) }\end{array}$ & $\begin{array}{l}\text { DIA } 1 \\
\text { (III) }\end{array}$ & $\begin{array}{c}\text { DIA } 2 \\
\text { (III) }\end{array}$ & $\begin{array}{l}\text { DEPTH } \\
\text { (IN) }\end{array}$ & $\begin{array}{l}\text { DIA } 1 \\
\text { (IN) }\end{array}$ & $\begin{array}{l}\text { DIA } 2 \\
\text { (IN) }\end{array}$ & $\begin{array}{l}\text { DEPIH } \\
\text { (IN) }\end{array}$ & $\begin{array}{l}\text { DIA } 1 \\
\text { (IN) }\end{array}$ & $\begin{array}{l}\text { oIA } 2 \\
\text { (IN) }\end{array}$ & $\begin{array}{l}\text { DEPTH } \\
\text { (1N) }\end{array}$ \\
\hline 1005 & $3301-1$ & & & & & & & & & & & & & & & & & & & & \\
\hline 1006 & $301-8$ & & & & & & & & & & & & & & & & & & & & \\
\hline 1007 & $3301-c$ & & & & & & & & & & & & & & & & & & & & \\
\hline 1008 & 3301-D & & & & & & & & & & & & & & & & & & & & \\
\hline 1029 & 3301-E & & & & & & & & & & & & & & & & & & & & \\
\hline 1030 & 3302-E & & & & & & & & & & & & 0.242 & 0.153 & 0.125 & 0.11 & 0.105 & 0.075 & & 0.083 & 0.03 \\
\hline 1016 & $3303-1$ & No & & 4.91 & no & & & & & & & & 0.107 & 0.099 & 0.062 & 0.119 & 0.087 & 0.029 & 0.057 & 0.055 & 0.01 \\
\hline 1015 & $3303-8$ & no & & 2.45 & no & & & & & & & & 0.144 & 0.107 & 0.07 & 0.072 & 0.079 & 0.061 & 0.085 & 0.11 & 0.045 \\
\hline 1016 & $3303-c$ & no & & 4.91 & $\begin{array}{l}\text { No } \\
\text { No }\end{array}$ & & & & & & & & 0.145 & 0.193 & 0.1 & 0.083 & 0.08 & 0.045 & 0.096 & 0.129 & 0.032 \\
\hline 1021 & $3303-0$ & $\begin{array}{l}\text { NO } \\
\text { YES }\end{array}$ & 0.05 & $\begin{array}{l}3.98 \\
3.14\end{array}$ & no & & 0.27 & 0.209 & & & & & 0.111 & 0.163 & 0.104 & 0.117 & 0.141 & 0.106 & 0.116 & 0.116 & 0.058 \\
\hline $\begin{array}{l}1017 \\
1018\end{array}$ & $\begin{array}{l}3304-A \\
3304-8\end{array}$ & $\begin{array}{l}\text { YES } \\
\text { YES }\end{array}$ & 0.08 & 4.91 & MO & & 0.321 & 0.369 & & & & & 0.087 & 0.121 & 0.059 & 0.063 & 0.132 & 0.052 & 0.055 & 0.098 & 0.022 \\
\hline $\begin{array}{l}1018 \\
1019\end{array}$ & $\begin{array}{l}3304-8-1 \\
3304-C\end{array}$ & YES & 0.014 & 5.96 & nO & & 0.282 & 0.271 & 0.132 & 0.263 & 0.274 & 0.293 & 0.091 & 0.107 & 0.125 & 0.053 & 0.053 & 0.086 & 0.071 & 0.083 & 0.032 \\
\hline $\begin{array}{l}1019 \\
1020\end{array}$ & $330<-0$ & YES & $<.0625$ & 4.91 & No & & PINHOLE & PINHOLE & & & & & 0.166 & 0.15 & 0.125 & 0.144 & 0.181 & 0.125 & 0.162 & 0.276 & 0.125 \\
\hline 1025 & $3305-\AA$ & & & & & & & & & & & & & & & & & & & & \\
\hline 1023 & $3305-8$ & & & & мо & & & & & & & & & & & & & & & & \\
\hline 1026 & $3305-c$ & & & & & & & & & & & & & ' & & & & & & & \\
\hline 1026 & $3306-A$ & & & & & & & & & & & & & & & & & & & & \\
\hline 1031 & $3306-8$ & & & & & & & & & & & & & & & & & & & & \\
\hline 1027 & $3306-c$ & & & & & & & & & & $\cdots$ & & & & & & & & & & \\
\hline 1028 & $3306-0$ & & & & & & & & & & & & 0.214 & 0.214 & 0.045 & 0.207 & 0.182 & 0.039 & 0.214 & 0.214 & 0.045 \\
\hline 1032 & $3307-1$ & no & & $\begin{array}{l}7.07 \\
2.06\end{array}$ & NO & & & & & & & & 0.126 & 0.124 & 0.014 & 0.133 & $\begin{array}{l}0.102 \\
0.09\end{array}$ & 0.033 & 0.2614 & & \\
\hline 1033 & $3307-8$ & no & & $\begin{array}{l}2.06 \\
1.77\end{array}$ & $\begin{array}{l}\text { No } \\
\text { No }\end{array}$ & & & & & & & & 0.155 & 0.114 & .139 & 0.208 & 0.146 & 139 & 0.196 & 0.112 & 0.084 \\
\hline 1034 & $3038-A$ & No & $0<08$ & $\begin{array}{l}1.77 \\
2.77\end{array}$ & YES & 0.04 & 0.352 & 0.234 & 0.334 & 0.242 & 0.056 & 0.056 & 0.329 & 0.202 & 0.11 & 0.235 & 0.14 & 0.042 & 0.229 & 0.156 & 0.076 \\
\hline
\end{tabular}




\begin{tabular}{|c|c|c|c|c|c|c|c|c|c|c|c|c|c|c|c|c|c|}
\hline HOT No. & TEST NO. & $\begin{array}{l}\text { BUMPER PLA } \\
\text { DMIN }\end{array}$ & $\begin{array}{l}\text { FE HOLE } \\
\text { DMMX }\end{array}$ & $\begin{array}{l}\text { BACKUALLL } \\
\text { PERFORATED? }\end{array}$ & $\begin{array}{l}\text { BACKUALL EQ } \\
\text { MOLE OIAMETER D }\end{array}$ & $\begin{array}{l}\text { BACKUALL } \\
\text { DAMAGE AREA }\end{array}$ & $\begin{array}{l}\text { BACKUALL } \\
\text { SPALLEO? }\end{array}$ & $\begin{array}{l}\text { BACKUALL } \\
\text { SPALL }\end{array}$ & HOLE 1 & HOLE 2 & HOLE 3 & & & CRAT & & CRA & R 3 \\
\hline 1140 & $3401-A$ & (IN) & (IN) & & (IN) & (sa. IH.) & SPALLEU? & $\begin{array}{l}\text { SPALL. AREA } \\
\text { (SO. IN.) }\end{array}$ & $\begin{array}{l}\text { DIA } \\
\text { (III) }\end{array}$ & $\begin{array}{l}\text { DIA } \\
\text { (IH) }\end{array}$ & $\begin{array}{l}\text { DIA } \\
\text { (IN) }\end{array}$ & DIA & DEPTH & DIA & DEPIH & DIA & DEPTH \\
\hline 1144 & $\begin{array}{l}3401-A \\
3401-B\end{array}$ & 0.686 & 0.686 & YES & 2.96 & 8.3 & nо & & 6.87 & & & & (IN) & (IM) & (IN) & (IN) & (IN) \\
\hline 1139 & $3401-C$ & 0.653 & 0.653 & YES & 2.81 & 7.07 & No & & 2.81 & & & & & & & & \\
\hline 1138 & 3401-D & 0.62 & 0.62 & YES & 2.43 & 8.97 & No & & 2.43 & & & & & & & & \\
\hline 1143 & $3402-\lambda$ & 0.579 & 0.579 & YES & 1.63 & 8.3 & No & & 1.63 & & & & & & & & \\
\hline 1145 & $3402-8$ & 0.673 & 0.673 & YES & 2.41 & 7.07 & no & & 2.4 & & & & & & & & \\
\hline 1142 & $3402-c$ & 0.674 & 0.674 & YES & 2.09 & 7.07 & MO & & 2.09 & & & & & & & & \\
\hline 1141 & $3402-D$ & $\begin{array}{r}0.61 \\
0.561\end{array}$ & 0.61 & YES & 2.55 & 7.07 & No & & 2.55 & & & & & & & & \\
\hline 1149 & $3403-1$ & 0.561 & 0.561 & YES & 1.5 & 8.97 & พо & & 1.5 & & & & & & & & \\
\hline 1148 & $3403-8$ & $\begin{array}{l}0.636 \\
0.639\end{array}$ & 0.636 & YES & 0.806 & 16.76 & YES & 0.67 & 0.806 & & & & & & & & \\
\hline 1147 & $3403-c$ & $\begin{array}{r}0.639 \\
0.62\end{array}$ & 0.639 & YES & 0.731 & 18.7 & YES & 0.64 & 0.731 & & & & & & & & \\
\hline 1146 & 3403-D & $\begin{array}{r}0.62 \\
0.573\end{array}$ & 0.62 & YES & 2.49 & 15.9 & No & & 2.49 & & & & & & & & \\
\hline 1152 & $3404-A$ & $\begin{array}{l}0.573 \\
0.654\end{array}$ & 0.573 & YES & 0.852 & 14.19 & No & & 0.852 & & & & & & & & \\
\hline 1153 & $3404-8$ & $\begin{array}{l}0.654 \\
0.654\end{array}$ & 0.654 & YES & 8 & 50.27 & NO & & 8 & & & & & & & & \\
\hline 1154 & $3404-C$ & $\begin{array}{l}0.654 \\
0.641\end{array}$ & 0.654 & YES & 5.75 & 25.97 & no & & 5.75 & & & & & & & & \\
\hline 1156 & $3404-0$ & $\begin{array}{l}0.641 \\
0.623\end{array}$ & 0.641 & YES & 5.5 & 23.76 & no & & 5.5 & & & & & & & & \\
\hline 1165 & $3405-A$ & $\begin{array}{l}0.623 \\
0.407\end{array}$ & $\begin{array}{l}0.623 \\
0.407\end{array}$ & YES & 4.5 & 15.9 & No & & 4.5 & & & & & & & & \\
\hline 1166 & $3405-8$ & 0.46 & $\begin{array}{r}0.407 \\
0.46\end{array}$ & YES & 0.261 & 5.39 & no & & 0.261 & & & 0.151 & 0.073 & 0.12 & 0.056 & 0.119 & 0.076 \\
\hline 1167 & $3405-c$ & 0.494 & $\begin{array}{l}0.46 \\
0.494\end{array}$ & $\begin{array}{l}\text { YES } \\
\text { NO }\end{array}$ & 0.169 & 8.92 & NO & & 0.169 & & & 0.126 & 0.047 & 0.109 & 0.018 & & \\
\hline 1168 & $3405-0$ & 0.516 & 0.516 & $\begin{array}{l}\text { No } \\
\text { NO }\end{array}$ & & $\begin{array}{l}9.62 \\
8.97\end{array}$ & No & & & & & & & & & & \\
\hline 1161 & $3406-A$ & 0.42 & 0.42 & YES & & $\begin{array}{l}8.97 \\
4.91\end{array}$ & No & & 0.231 & & & & & & & & \\
\hline 1162 & $3406-8$ & 0.456 & 0.456 & no & 0.231 & $\begin{array}{r}4.91 \\
8.3\end{array}$ & $\begin{array}{l}\text { Ho } \\
\text { No }\end{array}$ & & 0.231 & & & 0.195 & 0.13 & 0.181 & 0.062 & 0.198 & 0.121 \\
\hline 1163 & $3406-c$ & 0.459 & 0.459 & No & & $\begin{array}{r}8.3 \\
10.29\end{array}$ & $\begin{array}{l}\text { NO } \\
\text { NO }\end{array}$ & & & & & 0.16 & 0.039 & 0.149 & 0.097 & 0.167 & 0.082 \\
\hline 1164 & $3406-D$ & 0.478 & 0.478 & No & & $\begin{array}{r}10.29 \\
7.07\end{array}$ & $\begin{array}{l}\text { NO } \\
\text { NO }\end{array}$ & & & & & 0.076 & 0.047 & 0.119 & 0.038 & 0.115 & 0.031 \\
\hline 1169 & 3406-01 & 0.485 & 0.485 & YES & 0.265 & 5.94 & no & & 0.26 & & & 0.125 & 0.118 & & & & \\
\hline 1160 & $3407-1$ & 0.414 & 0.414 & YES & 0.445 & 5.94 & no & & $\begin{array}{r}0.26 \\
0.445\end{array}$ & 0.05 & & & & & & & \\
\hline 1159 & $3407-B$ & 0.431 & 0.431 & YES & 0.638 & 7.07 & No & & $\begin{array}{l}0.445 \\
0.638\end{array}$ & & & 0.129 & 0.096 & 0.164 & 0.087 & 0.214 & 0.085 \\
\hline 1158 & $3407-c$ & 0.477 & 0.477 & YES & 0.109 & 11.04 & ผо & & $\begin{array}{l}0.638 \\
0.109\end{array}$ & & & 0.169 & 0.112 & 0.158 & 0.064 & 0.132 & 0.056 \\
\hline 1157 & $3407-D$ & 0.503 & 0.503 & No & & 15.9 & No & & & & & $\begin{array}{l}0.124 \\
0.138\end{array}$ & $\begin{array}{l}0.039 \\
0.109\end{array}$ & $\begin{array}{l}0.135 \\
0.136\end{array}$ & $\begin{array}{l}0.029 \\
0.107\end{array}$ & 0.122 & 0.03 \\
\hline
\end{tabular}




\begin{tabular}{|c|c|c|c|c|c|c|c|c|c|c|c|c|c|c|c|c|c|}
\hline \multirow{2}{*}{ SHOT No. } & \multirow{2}{*}{ IESI NO. } & \multirow{2}{*}{$\begin{array}{l}\text { BUMPER PLATE } \\
\text { DHIN } \\
\text { (IW) }\end{array}$} & \multirow[b]{2}{*}{$\begin{array}{l}\text { HOLE } \\
\text { DMAXX } \\
\text { (III) }\end{array}$} & \multirow{2}{*}{$\begin{array}{l}\text { BACKUALL } \\
\text { PERFORATEO? }\end{array}$} & \multirow{2}{*}{$\begin{array}{l}\text { BACKHALL EQ } \\
\text { HOLE DINAETER } \\
\text { (IN) }\end{array}$} & \multirow{2}{*}{$\begin{array}{l}\text { BACKUALL } \\
\text { DAMGE AREA } \\
\text { (sO. IN.) }\end{array}$} & \multirow{2}{*}{$\begin{array}{l}\text { 8ACKUALL } \\
\text { SPALLED? }\end{array}$} & \multirow{2}{*}{$\begin{array}{l}\text { BACKUALL } \\
\text { SPALL AREA } \\
\text { (50. III.) }\end{array}$} & \multirow{2}{*}{$\begin{array}{l}\text { MOLE I } \\
\text { DIA } \\
\text { (IN) }\end{array}$} & \multirow{2}{*}{$\begin{array}{l}\text { MOLE } 2 \\
\text { DIA } \\
\text { (IN) }\end{array}$} & \multirow{2}{*}{$\begin{array}{l}\text { HOLE } 3 \\
\text { DIA } \\
\text { (IN) }\end{array}$} & \multicolumn{2}{|c|}{ CRATER 1} & \multicolumn{2}{|c|}{ CRATER 2} & \multicolumn{2}{|c|}{ CRAIER 3} \\
\hline & & & & & & & & & & & & $\begin{array}{l}\text { DIA } \\
\text { (IN) }\end{array}$ & $\begin{array}{l}\text { DEPTH } \\
\text { (III) }\end{array}$ & $\begin{array}{l}\text { DIA } \\
\text { (III) }\end{array}$ & $\begin{array}{l}\text { DEPTH } \\
\text { (IN) }\end{array}$ & $\begin{array}{l}\text { DIA } \\
\text { (III) }\end{array}$ & $\begin{array}{l}\text { DEPTH } \\
\text { (IN) }\end{array}$ \\
\hline 1042 & $4001-A$ & 0.535 & 0.704 & No & & 3.56 & YES & 0.25 & & & & 0.165 & 0.024 & 0.122 & 0.018 & 0.254 & 0.015 \\
\hline 1040 & $4001-B$ & 0.596 & 0.755 & No & & 3.98 & no & & & & & 0.128 & 0.043 & 0.158 & 0.015 & 0.121 & 0.023 \\
\hline 1041 & $4001-C$ & 0.655 & 0.851 & No & & 3.14 & No & & & & & 0.135 & 0.027 & 0.11 & 0.03 & 0.077 & 0.019 \\
\hline 1043 & $4001-0$ & 0.665 & 0.81 & No & & 5.39 & No & & & & & & & & & & \\
\hline 1046 & $4002-1$ & 0.46 & 1.041 & мо & & 5.49 & No & & & & & & & & & & \\
\hline 1044 & $4002-8$ & 0.482 & 1.057 & No & & 2.49 & No & & & & & & & & & & \\
\hline 1045 & $4002-C$ & 0.533 & 1.349 & YES & 0.162 & 4.91 & No & & 0.162 & & & 0.197 & 0.032 & 0.223 & 0.062 & 0.243 & 0.105 \\
\hline 1047 & $4002-0$ & 0.571 & 1.41 & No & & 7.07 & no & & & & & & & & & & \\
\hline 1056 & $4002-E$ & 0.561 & 1.191 & No & & 8.3 & No & & & & & & & & & & \\
\hline 1048 & $4003-1$ & 0.519 & 0.696 & no & & 7.07 & No & & & & & & & & & & \\
\hline 1049 & $4003 \cdot B$ & 0.622 & 0.795 & so & & 5.94 & NO & & & & & & & & & & \\
\hline 1051 & $4003-c$ & 0.511 & 0.674 & No & & 3.98 & No & & & & & 0.18 & 0.05 & 0.104 & 0.015 & & \\
\hline 1050 & 4003-0 & 0.617 & 0.887 & No & & NO DAMAGE & No & & & & & & & & & & \\
\hline 1052 & $4004-\AA$ & 0.427 & 1.042 & nо & & 7.07 & NO & & & & & & & & & 0.90 & 0058 \\
\hline 1053 & 4004-B & 0.673 & 1.366 & YES & 0.105 & 7.69 & No & & 0.105 & & & 0.158 & 0.034 & 0.135 & 0.053 & $\begin{array}{l}0.169 \\
0.159\end{array}$ & $\begin{array}{l}0.058 \\
0.073\end{array}$ \\
\hline 1056 & $4004-c$ & 0.552 & 1.315 & мо & & 5.39 & No & & & & & 0.167 & 0.1 & 0.11 & 0.125 & 0.159 & 0.073 \\
\hline
\end{tabular}

$\underset{\infty}{\varpi}$

\begin{tabular}{|c|c|c|c|c|c|c|c|c|c|c|c|c|c|c|c|c|c|c|c|c|c|}
\hline \multirow{2}{*}{ SHOT мо. } & \multirow[t]{2}{*}{ TEST nO. } & \multirow{2}{*}{$\begin{array}{l}\text { OACKMALL } \\
\text { PERForated? }\end{array}$} & \multirow{2}{*}{$\begin{array}{l}\text { BACKLALL EQ } \\
\text { HOLE DINMETER D } \\
\text { (IN) }\end{array}$} & \multirow{2}{*}{$\begin{array}{l}\text { BACKUALL } \\
\text { DAMUCE AREA } \\
\text { (SQ. IN.) }\end{array}$} & \multirow{2}{*}{$\begin{array}{l}\text { BACKWALL } \\
\text { SPALLED? }\end{array}$} & \multirow{2}{*}{$\begin{array}{l}\text { BACKUALL } \\
\text { SPALL AREA } \\
\text { (SO. IN.) }\end{array}$} & \multicolumn{2}{|c|}{ HOLE 1} & \multicolumn{2}{|c|}{ HOLE 2} & \multicolumn{2}{|c|}{ HOLE 3} & \multicolumn{3}{|c|}{ CRATER 1} & \multicolumn{3}{|c|}{ CRATER 2} & \multicolumn{3}{|c|}{ CRATER 3} \\
\hline & & & & & & & $\begin{array}{l}\text { DIA I } \\
\text { (III) }\end{array}$ & $\begin{array}{c}\text { DIA } 2 \\
\text { (III) }\end{array}$ & $\begin{array}{l}\text { DIA } 1 \\
\text { (1N) }\end{array}$ & $\begin{array}{l}\text { DIA } 2 \\
\text { (III) }\end{array}$ & $\begin{array}{l}\text { ola } 1 \\
\text { (II) }\end{array}$ & $\begin{array}{l}\text { oin } 2 \\
\text { (III) }\end{array}$ & $\begin{array}{l}\text { DIA } 1 \\
\text { (IN) }\end{array}$ & $\begin{array}{r}\text { DIA } 2 \\
\text { (IM) }\end{array}$ & $\begin{array}{l}\text { DEPTH } \\
\text { (II) }\end{array}$ & $\begin{array}{l}\text { DIA } 1 \\
\text { (IN) }\end{array}$ & $\begin{array}{c}\text { DIA } 2 \\
\text { (IN) }\end{array}$ & $\begin{array}{l}\text { DEPTH } \\
\text { (IN) }\end{array}$ & $\begin{array}{l}\text { DIA } 1 \\
\text { (IN) }\end{array}$ & $\begin{array}{l}\text { DIA } 2 \\
\text { (IH) }\end{array}$ & $\begin{array}{l}\text { DEPYH } \\
\text { (IN) }\end{array}$ \\
\hline 1042 & $6001-A$ & YES & 0.445 & 3.56 & No & & 0.445 & 0.455 & & & & & 0.304 & 0.26 & 0.083 & 0.313 & 0.274 & 0.038 & 0.14 & 0.105 & 0.01 \\
\hline 1040 & $4001-8$ & YES & 0.633 & 4.45 & no & & 0.9 & 0.4 & 0.6 & 0.3 & & & 0.231 & 0.191 & 0.054 & 0.234 & 0.204 & 0.061 & 0.164 & 0.131 & 0.029 \\
\hline 1041 & 6001-C & YES & 0.523 & 4.91 & no & & 0.8 & 0.34 & & & & & 0.156 & 0.127 & 0.017 & 0.191 & 0.131 & 0.052 & 0.244 & 0.147 & 0.056 \\
\hline 1043 & $6001-0$ & YES & 0.434 & 4.91 & HO & & 0.323 & 0.251 & 0.242 & 0.27 & 0.178 & 0.125 & & & & & & & & & \\
\hline 1046 & $4002-A$ & NO & & NO DAMAGE & No & & & & & & & & & & & & & & & & \\
\hline 1044 & $4002-8$ & No & & HO DAMAGE & No & & & & & & & & & & & & & & & & \\
\hline 1045 & $4002-C$ & no & & NO DAMAGE & NO & & & & & & & & & & & & & & & & \\
\hline 1047 & $4002-0$ & No & & NO DNMAGE & No & & & & & & & & & & & & & & & & \\
\hline 1056 & $4002-E$ & No & & NO DAMAGE & NO & & & & & & & & & & & & & & & & \\
\hline 1048 & $4003 \cdot \AA$ & YES & 0.602 & 2.41 & NO & & 0.71 & 0.51 & & & & & & & & & & & & & \\
\hline 1049 & $4003-8$ & YES & 0.711 & 3.98 & No & & 0.6 & 0.4 & 0.49 & 0.36 & 0.3 & 0.3 & 0.146 & 0.146 & 0.053 & 0.171 & $\ldots$ & 0.030 & 0.18 & 0.131 & 0.079 \\
\hline 1051 & $4003-c$ & YES & 0.504 & 2.41 & No & & 0.504 & 0.504 & & & & & 0.151 & 0.174 & 0.048 & 0.123 & 0.207 & 0.073 & & & \\
\hline 1050 & $6003-0$ & YES & 0.51 & 6.47 & no & & 0.6 & 0.33 & 0.25 & 0.25 & & & 0.192 & 0.208 & 0.063 & 0.138 & 0.174 & 0.065 & 0.167 & 0.148 & $\therefore \quad 0.129$ \\
\hline 1052 & $4004-A$ & No & & NO DNMAGE & No & & & & & & & & & & & & & & & & \\
\hline 1053 & $4004-8$ & no & & NO DNMAGE & No & & & & & & & & & & & & & & & & E. \\
\hline 1054 & $4004-C$ & NO & & NO DAMAGE & NO & & & & & & & & & & & & & & & & \\
\hline
\end{tabular}




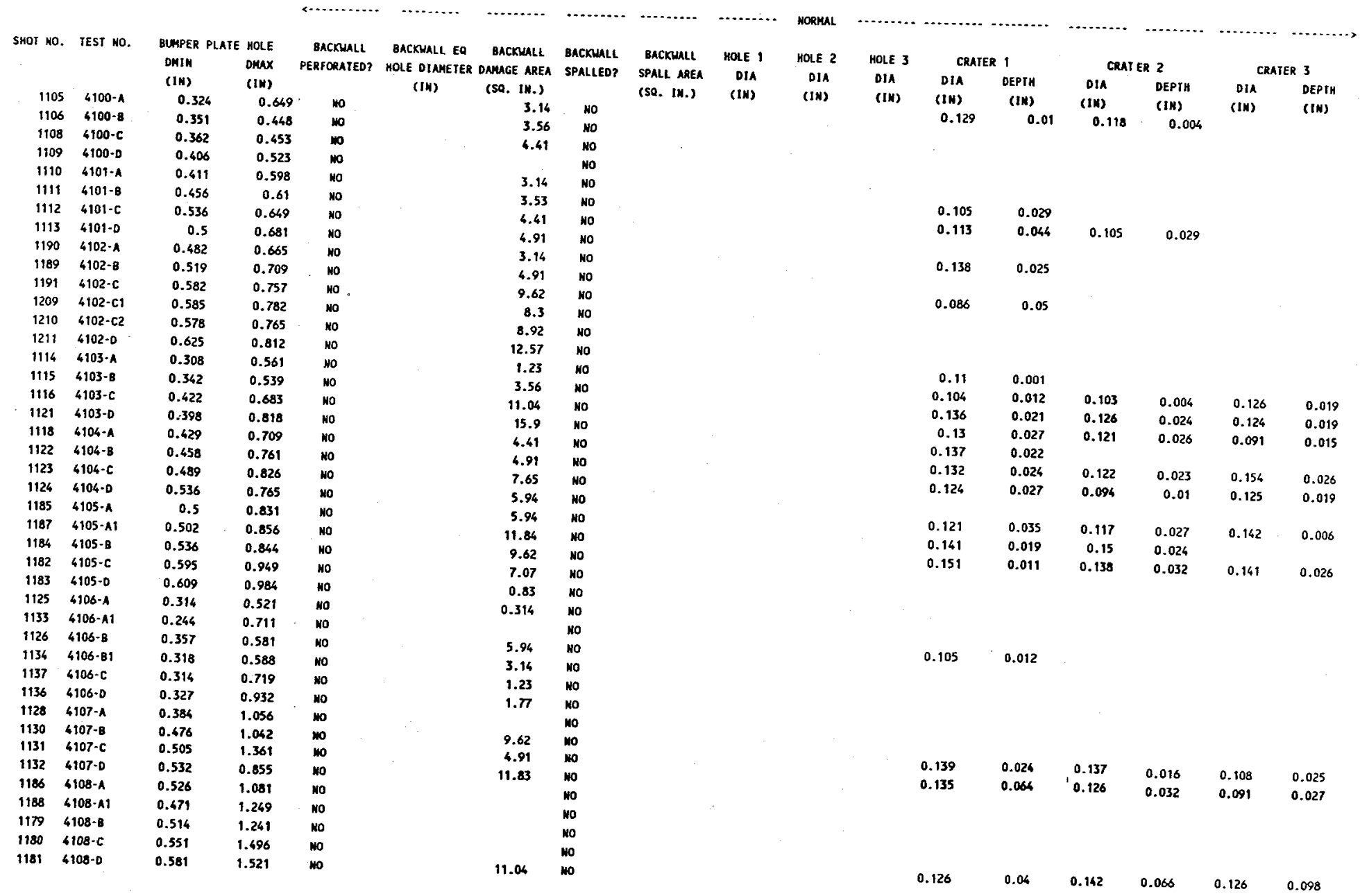

D4100SER. WK1 


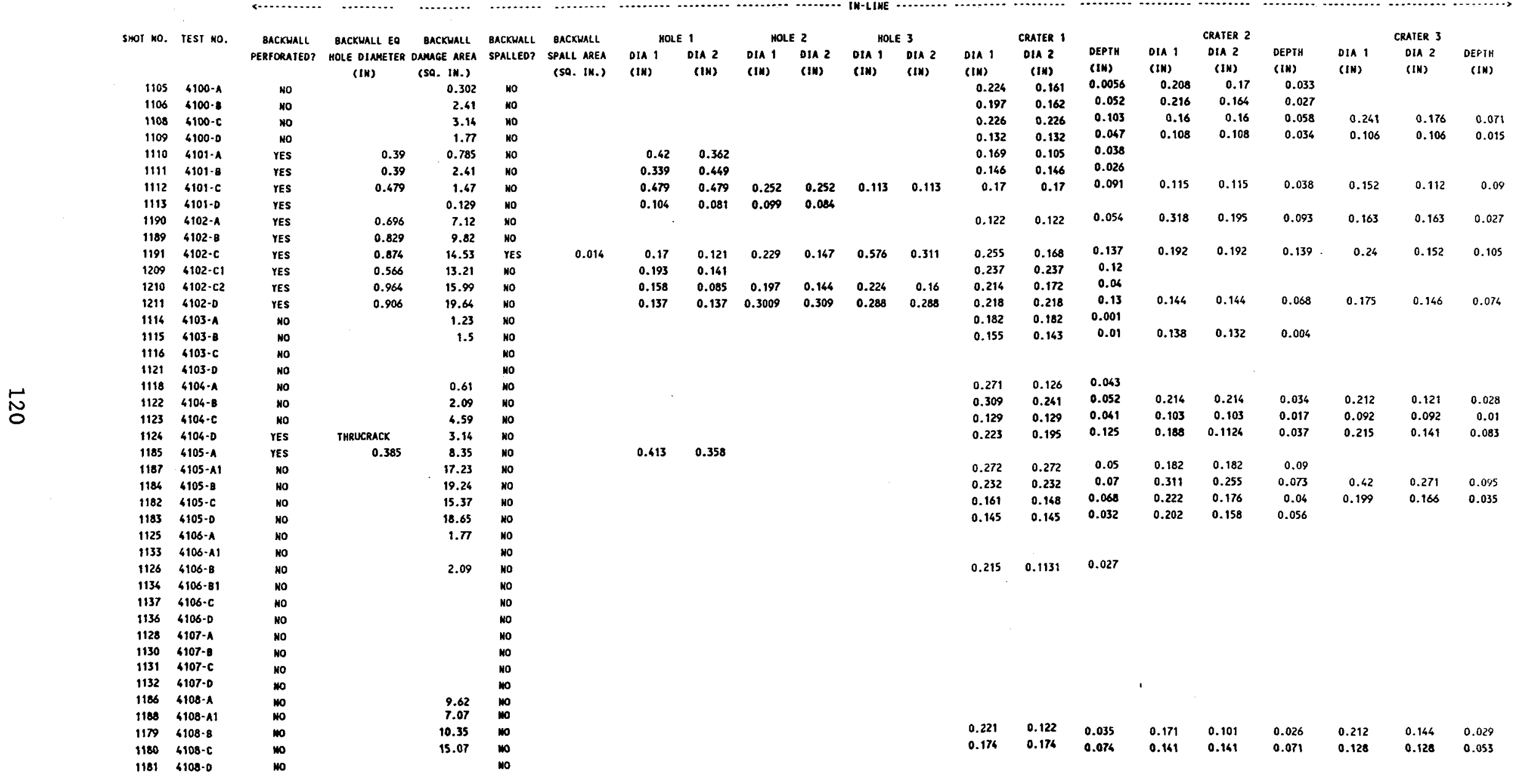

D4100SER.WK1 (Continued) 


\begin{tabular}{|c|c|c|c|c|c|c|c|c|c|c|c|c|c|c|c|c|c|}
\hline mo. & IEST wO. & $\begin{array}{l}\text { IMAPER PL } \\
\text { OHIN } \\
\text { (IW) }\end{array}$ & $\begin{array}{l}\text { Late mole } \\
\text { omax } \\
\text { (in) }\end{array}$ & 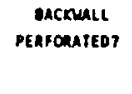 & $\begin{array}{l}\text { BACRUAL EQ } \\
\text { HOLE OINMETER D } \\
\text { (III) }\end{array}$ & $\begin{array}{l}\text { MacrunLL } \\
\text { DNMCE AREA } \\
\text { (SO. IM.) }\end{array}$ & $\begin{array}{l}\text { macnuale } \\
\text { spatizo? }\end{array}$ & $\begin{array}{l}\text { mecrull } \\
\text { spall mere } \\
\text { (so. In.) }\end{array}$ & $\begin{array}{l}\text { MoLE I } \\
\text { Dis } \\
\text { (III) }\end{array}$ & $\begin{array}{l}\text { MOLE } 2 \\
\text { DIA } \\
\text { (III) }\end{array}$ & $\begin{array}{l}\text { Mole } 3 \\
\text { ois } \\
\text { (III) }\end{array}$ & $\begin{array}{c}\text { CRAI } \\
\text { Din } \\
\text { (III) }\end{array}$ & $\begin{array}{l}1 \\
\text { DEPTH } \\
\text { (III) }\end{array}$ & $\begin{array}{l}\text { 'cal } \\
\text { oin } \\
\text { (III) }\end{array}$ & $\begin{array}{l}\text { OE } 2 \\
\text { OEPTM } \\
\text { (II) }\end{array}$ & $\begin{array}{c}\text { com } \\
\text { oin } \\
\text { (III) }\end{array}$ & $\begin{array}{l}\text { ER } 3 \\
\text { OEP I K } \\
\text { (III) }\end{array}$ \\
\hline 1058 & $4109-\AA$ & 0.361 & 0.456 & 10 & & 3.14 & wo & $\cdots$ & & & & 0.178 & 0.062 & & & & \\
\hline 1059 & $6109-8$ & 0.414 & 0.466 & mo & & 3.98 & mo & & - & & & 0.165 & 0.043 & 0.226 & 0.048 & 0.132 & 0.041 \\
\hline 1050 & \$109-c & 0.482 & 0.55 & wo & & 5.94 & mo & & & & & 0.11 & 0.017 & 0.1 & 0.041 & 0.08 & 0.011 \\
\hline 1062 & $4109-D$ & 0.494 & 0.58 & mo & & 10.35 & mo & & & & & 0.114 & 0.032 & 0.1 & 0.023 & 0.096 & 0.004 \\
\hline 1064 & $4190-A$ & 0.468 & 0.569 & No & & 2.49 & мо & & & & & 0.188 & 0.034 & 0.119 & 0.043 & 0.1 & 0.019 \\
\hline 1065 & $4110-\mathrm{B}$ & 0.502 & 0.61 & no & & 2.41 & mo & & & & & 0.345 & 0.082 & 0.215 & 0.115 & & \\
\hline 1068 & \$110-c & 5.62 & 7.51 & no & & 4.71 & no & & & & & 0.119 & 0.062 & & & & \\
\hline 1059 & $4110-0$ & 0.586 & 0.689 & No & & 5.39 & mo & & & & & & & & & & \\
\hline $\begin{array}{l}1070 \\
1071\end{array}$ & $\begin{array}{l}4111-1 \\
4111-8\end{array}$ & $\begin{array}{l}0.515 \\
5.575\end{array}$ & $\begin{array}{l}0.693 \\
0.721\end{array}$ & No & & $\begin{array}{r}3.53 \\
8.3\end{array}$ & $\begin{array}{l}\text { No } \\
\text { No }\end{array}$ & & & & & $\begin{array}{l}0.148 \\
0.116\end{array}$ & $\begin{array}{l}0.026 \\
0.029\end{array}$ & $\begin{array}{l}0.102 \\
0.135\end{array}$ & $\begin{array}{l}0.015 \\
0.036\end{array}$ & 0.132 & 0.041 \\
\hline $\begin{array}{l}1071 \\
1072\end{array}$ & $\begin{array}{l}4111-8 \\
4111-c\end{array}$ & 0.66 & 0.821 & no & & 8.3 & No & & & & & & & & & & \\
\hline 1073 & 4111-D & 0.681 & 0.76 & no & & 6.47 & мо & & & & & & & & & & \\
\hline 1074 & $4112-a$ & 0.33 & 0.544 & мо & & $1 . \pi$ & No & & & & & 0.206 & 0.011 & 0.109 & 0.001 & 0.28 & 0.021 \\
\hline 1075 & $4112-8$ & 0.455 & 0.309 & wo & & 7.07 & мо & & & & & 0.111 & 0.03 & 0.1 & 0.015 & 0.067 & 0.007 \\
\hline 1076 & $4112-c$ & 0.429 & 0.6 & no & & 3.14 & MO & & & & & 0.114 & 0.036 & 0.161 & 0.033 & 0.139 & 0.027 \\
\hline $10 \pi$ & $4112-0$ & 0.556 & 0.78 & mo & & 5.94 & mo & & & & & 0.147 & 0.033 & 0.1 & 0.048 & 0.118 & 0.049 \\
\hline 1078 & 41133-A & 0.4 & 0.785 & no & & 9.62 & mo & & & & & 0.22 & 0.007 & 0.16 & 0.007 & & \\
\hline 1079 & $4113-8$ & 0.446 & 0.79 & No & & 3.14 & no & & & & & 0.183 & 0.035 & 0.121 & 0.037 & 0.09 & 0.05 \\
\hline 1080 & (\$113-c & 0.668 & 0.872 & res & 0.053 & 2.41 & мo & & 0.053 & & & 0.133 & 0.06 & 0.136 & 0.057 & 0.123 & 0.023 \\
\hline 1082 & 4113-D & 0.601 & 0.778 & no & & 2.41 & мо & & & & & 0.166 & 0.043 & 0.162 & 0.024 & 0.125 & 0.021 \\
\hline 1083 & 4116-A & 0.532 & 0.827 & No & & 4.91 & No & & & & & 0.151 & 0.016 & 0.197 & 0.024 & 0.164 & 0.011 \\
\hline 1084 & $4114-8$ & 0.559 & 0.897 & No & & 7.07 & mo & & & & & 0.181 & 0.056 & 0.201 & 0.106 & 0.185 & 0.076 \\
\hline 1085 & $4114-c$ & 0.659 & 0.956 & no & & 9.62 & No & & & & & 0.179 & 0.104 & 0.131 & 0.028 & 0.145 & 0.033 \\
\hline 1086 & 4114-D & 0.7 & 1.039 & мо & & 11.04 & no & & & & & 0.183 & 0.077 & 0.174 & 0.097 & 0.189 & 0.125 \\
\hline 1089 & \$115-A & $\begin{array}{l}0.207 \\
0.259\end{array}$ & $\begin{array}{l}0.238 \\
0.354\end{array}$ & $\begin{array}{l}\text { No } \\
\text { no }\end{array}$ & & & $\begin{array}{l}\text { mo } \\
\text { wo }\end{array}$ & & & & & & & & & & \\
\hline $\begin{array}{l}1088 \\
1090\end{array}$ & $\begin{array}{l}4115-8 \\
4115-c\end{array}$ & $\begin{array}{l}0.251 \\
0.348\end{array}$ & $\begin{array}{l}0.354 \\
0.461\end{array}$ & $\begin{array}{l}\text { No } \\
\text { mo }\end{array}$ & & 2.41 & $\begin{array}{l}\text { No } \\
\text { wo }\end{array}$ & & & & & 0.181 & & & & & \\
\hline $\begin{array}{l}1090 \\
1091\end{array}$ & $\begin{array}{l}4115-c \\
4115-0\end{array}$ & $\begin{array}{l}0.348 \\
0.391\end{array}$ & 0.509 & wo & & $\begin{array}{l}2.41 \\
7.69\end{array}$ & mo & & & & & $\begin{array}{l}0.181 \\
0.968\end{array}$ & 0.017 & 0.112 & 0.016 & & \\
\hline $\begin{array}{l}1091 \\
1092\end{array}$ & 4116-A & 0.277 & 0.623 & mo & & & wo & & & & & 0.168 & 0.019 & 0.136 & 0.012 & & \\
\hline 1093 & $4116-8$ & 0.366 & 0.837 & mo & & & mo & & & & & & & & & & \\
\hline 1094 & $4116-c$ & 0.678 & 0.942 & wo & & 1.77 & No & & & & & 0.275 & 0.036 & 0.19 & 0.011 & 0.204 & 0.003 \\
\hline 1095 & $4116-0$ & $.518 / .218$ & $.75 / .37$ & no & & 5.96 & $\begin{array}{l}\text { No } \\
\text { No }\end{array}$ & & & & & 0.165 & 0.009 & 0.106 & 0.025 & 0.151 & 0.021 \\
\hline 1096 & $4117-A$ & 0.446 & 0.909 & no & & 2.09 & $\begin{array}{l}\text { No } \\
\text { mo }\end{array}$ & & & & & & & & & & \\
\hline 1097 & $4117-8$ & 0.474 & 1.162 & no & & & Mo & & & & & 0.375 & 0.062 & & & & \\
\hline 1098 & $4117-c$ & 0.55 & 1.232 & mo & & 6.51 & "No & & & & & 0.183 & 0.108 & 0.209 & 0.073 & 0.178 & 0.064 \\
\hline 1103 & 6117-0 & 0.692 & 1.443 & но & & 8.29 & no & & & & & 0.176 & 0.078 & 0.209 & 0.059 & 0.184 & 0.046 \\
\hline
\end{tabular}

D4100SER.WK1 (Continued) 


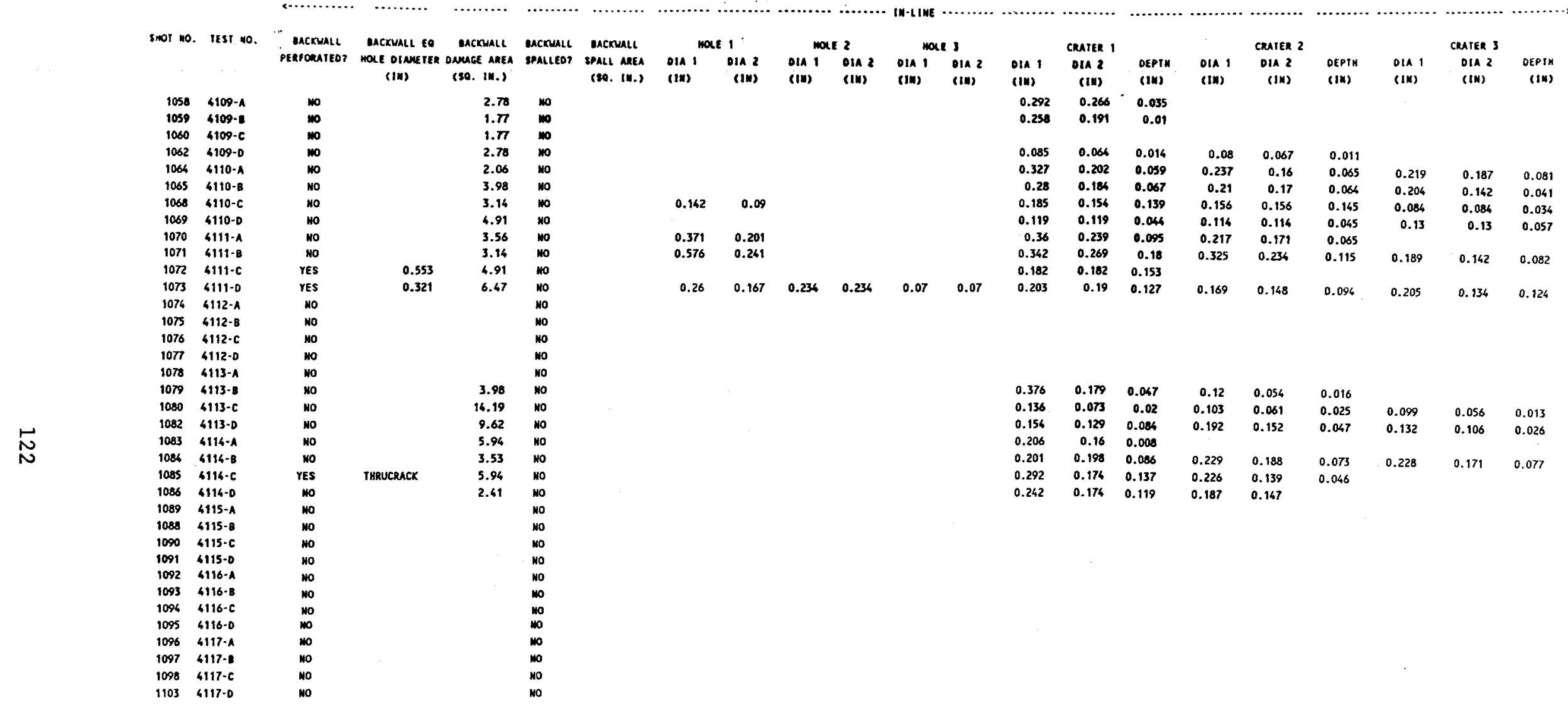

D4100SER.WK1 (Continued) 


\begin{tabular}{|c|c|c|c|c|c|c|c|c|c|c|c|c|c|c|c|c|c|}
\hline sHor mo. & rEST NO. & $\begin{array}{l}\text { BUMPER } \\
\text { DHIN }\end{array}$ & $\begin{array}{l}\text { PLATE HOLE } \\
\text { DHiAX }\end{array}$ & $\begin{array}{l}\text { BACKUALL } \\
\text { PERFORATED? }\end{array}$ & BACRELLL EQ & BACKUALL & BACKUALL & BACKLALL & MOLE 1 & HOLE 2 & HOLE 3 & & 1 & & & & \\
\hline & & (IN) & (IW) & & $\begin{array}{l}\text { HOLE DIMMETER } \\
\text { (IN) }\end{array}$ & $\begin{array}{l}\text { DAMAGE AREA } \\
\text { (SQ. IN.) }\end{array}$ & & $\begin{array}{l}\text { SPALL AREA } \\
\text { (SQ. IN.) }\end{array}$ & $\begin{array}{l}\text { DIA } \\
\text { (IN) }\end{array}$ & $\begin{array}{l}\text { DIA } \\
\text { (II) }\end{array}$ & $\begin{array}{l}\text { DIA } \\
\text { (IX) }\end{array}$ & $\begin{array}{l}\text { DIA } \\
\text { (IN) }\end{array}$ & $\begin{array}{c}\text { DEPYH } \\
\text { (II) }\end{array}$ & $\begin{array}{l}\text { DIA } \\
\text { (IN) }\end{array}$ & $\begin{array}{l}\text { DEPIH } \\
\text { (IN) }\end{array}$ & $\begin{array}{l}\text { DIA } \\
\text { (IN) }\end{array}$ & $\begin{array}{l}\text { OEPTH } \\
\text { (IN) }\end{array}$ \\
\hline 1170 & $9001-1$ & 0.538 & 0.711 & No & & 8.30 & No & & & & & & & & & & \\
\hline 1171 & $9001-A$ & 0.593 & 0.636 & No & & & NO & & & & & & & & & & \\
\hline 1172 & 9001-B & 0.464 & 0.625 & No & & 7.69 & NO & & & & & & & & & & \\
\hline 1173 & $9001-\mathrm{C}$ & 0.506 & 0.661 & Ho & & 8.92 & no & & & & & & & & & & \\
\hline 1174 & 9001-D & 0.460 & 0.639 & no & & 7.07 & No & & & & & & & & & & \\
\hline $11 \pi 5$ & $9002-A$ & 0.489 & 0.624 & No & & 4.91 & no & & & & & & & & & & \\
\hline 1176 & $9002-8$ & 0.502 & 0.685 & no & & 8.30 & $\begin{array}{l}\text { MO } \\
\text { No }\end{array}$ & & & & & & & & & & \\
\hline 1177 & $9002-c$ & $\begin{array}{l}0.514 \\
0.510\end{array}$ & $\begin{array}{l}0.686 \\
0.624\end{array}$ & $\begin{array}{l}\text { NO } \\
\text { NO }\end{array}$ & & $\begin{array}{l}9.62 \\
7.07\end{array}$ & $\begin{array}{l}\text { No } \\
\text { NO }\end{array}$ & & & & & & & & & & \\
\hline
\end{tabular}

\begin{tabular}{|c|c|c|c|c|c|c|c|c|c|c|c|c|c|c|c|c|c|c|c|c|c|}
\hline \multirow{2}{*}{ SHOY nO. } & \multirow{2}{*}{ TEST NO. } & \multirow{2}{*}{$\begin{array}{c}\text { BACKUALL } \\
\text { PERFORATED? }\end{array}$} & \multirow{2}{*}{$\begin{array}{l}\text { BACKHALL EO } \\
\text { HOLE DIMMETER } \\
\text { (IN) }\end{array}$} & \multirow{2}{*}{$\begin{array}{l}\text { BACKHALL } \\
\text { DAMGGE AREA } \\
\text { (SO. IN.) }\end{array}$} & \multirow{2}{*}{$\begin{array}{l}\text { BACKMALL } \\
\text { SPALLED? }\end{array}$} & \multirow{2}{*}{$\begin{array}{l}\text { BACKUALL } \\
\text { SPALL AREA } \\
\text { (SQ. IN.) }\end{array}$} & \multicolumn{2}{|c|}{ HOLE 1} & \multicolumn{2}{|c|}{ HOLE 2} & \multicolumn{2}{|c|}{ HOLE 3} & \multicolumn{3}{|c|}{ CRATER 1} & \multicolumn{3}{|c|}{ CRATER 2} & \multicolumn{3}{|c|}{ CRATER 3} \\
\hline & & & & & & & $\begin{array}{l}\text { DIA } 1 \\
\text { (IN) }\end{array}$ & $\begin{array}{c}\text { orA } 2 \\
\text { (III) }\end{array}$ & $\begin{array}{l}\text { DIA } 1 \\
\text { (III) }\end{array}$ & $\begin{array}{l}\text { DIA } 2 \\
\text { (III) }\end{array}$ & $\begin{array}{l}\text { DIA } 4 \\
\text { (II) }\end{array}$ & $\begin{array}{l}\text { DIA } 2 \\
\text { (IM) }\end{array}$ & $\begin{array}{l}\text { DIA I } \\
\text { (III) }\end{array}$ & $\begin{array}{c}\text { DIA } 2 \\
\text { (IN) }\end{array}$ & $\begin{array}{l}\text { DEPIH } \\
\text { (IN) }\end{array}$ & $\begin{array}{l}\text { DIA } 1 \\
\text { (III) }\end{array}$ & $\begin{array}{r}\text { DIA } 2 \\
\text { (IN) }\end{array}$ & $\begin{array}{l}\text { DEPTH } \\
\text { (II) }\end{array}$ & $\begin{array}{l}\text { OIA } 1 \\
\text { (IN) }\end{array}$ & $\begin{array}{l}\text { DiA } 2 \\
\text { (IH) }\end{array}$ & $\begin{array}{r}\text { DEPIH } \\
\text { (IN) }\end{array}$ \\
\hline 1170 & $9001-1$ & YES & 1.12 & 0.99 & no & & & & & & & & 0.339 & 0.201 & 0.104 & 0.204 & 0.165 & 0.088 & 0.174 & 0.122 & 0.021 \\
\hline 1171 & $9001-A$ & YES & 0.195 & & No & & 0.250 & 0.152 & & & & & 0.178 & 0.160 & 0.041 & 0.198 & 0.145 & 0.068 & 0.205 & 0.133 & 0.067 \\
\hline 1172 & $9001-8$ & YES & 0.474 & 3.56 & YES & 0.016 & 0.095 & 0.095 & 0.636 & 0.340 & & & 0.325 & 0.271 & 0.131 & 0.214 & 0.200 & 0.129 & & & \\
\hline 1173 & $9001-\mathrm{C}$ & Hо & & 1.23 & no & & & & & & & & 0.192 & 0.158 & 0.049 & 0.154 & 0.154 & 0.050 & 0.258 & 0.181 & 0.108 \\
\hline 1176 & 9001-D & YES & 0.197 & 5.39 & Mo & & 0.218 & 0.179 & & & & & 0.216 & 0.146 & 0.123 & 0.196 & 0.185 & 0.101 & 0.195 & 0.162 & 0.097 \\
\hline 1175 & $9002-A$ & YES & 0.433 & 3.56 & Mo & & 0.287 & 0.337 & 0.224 & 0.269 & & & & 0.133 & 0.088 & 0.239 & & & & & \\
\hline 1176 & $9002 \cdot \mathrm{B}$ & No & & 3.14 & No & & & & & & & & 0.172 & 0.135 & 0.00 & 0.0 .08 & 0.144 & 0.106 & 0.159 & 0.159 & 0.087 \\
\hline 1177 & $9002-\mathrm{c}$ & NO & & 2.78 & No & & & & & & & & 0.196 & 0.196 & 0.128 & 0.154 & 0.137 & 0.096 & 0.217 & 0.133 & 0.103 \\
\hline 1178 & $9002-D$ & No & & 3.53 & NO & & & & & & & & 0.174 & 0.174 & 0.043 & 0.158 & 0.146 & 0.085 & 0.158 & 0.158 & 0.069 \\
\hline
\end{tabular}




\begin{tabular}{|c|c|c|c|c|c|c|c|c|c|c|c|c|c|c|c|c|c|}
\hline \multirow[t]{2}{*}{ SHOT MO. } & \multirow[t]{2}{*}{ TEST NO. } & \multirow{2}{*}{$\begin{array}{l}\text { BLAPPER PLATE } \\
\text { DMIN }\end{array}$} & \multirow{2}{*}{$\begin{array}{l}\text { HOLE } \\
\text { DMAX }\end{array}$} & \multirow{2}{*}{$\begin{array}{l}\text { BACKUALL } \\
\text { PERFORATED? }\end{array}$} & \multirow{2}{*}{$\begin{array}{l}\text { BACKHALL EQ } \\
\text { HOLE DIAMETER } \\
\text { (IN) }\end{array}$} & \multirow{2}{*}{$\begin{array}{l}\text { BACKWALL : } \\
\text { DAMAGE AREA } \\
\text { (SQ. IN.) }\end{array}$} & \multirow{2}{*}{$\begin{array}{l}\text { BACKUALLL } \\
\text { SPALLED? }\end{array}$} & \multirow{2}{*}{$\begin{array}{l}\text { BACKUALL } \\
\text { SPALL AREA } \\
\text { (SO. IN.) }\end{array}$} & \multirow{2}{*}{$\begin{array}{l}\text { HOLE } 1 \\
\text { DIA } \\
\text { (IN) }\end{array}$} & \multirow{2}{*}{$\begin{array}{l}\text { HOLE } 2 \\
\text { DIA } \\
\text { (II) }\end{array}$} & \multirow{2}{*}{$\begin{array}{l}\text { HOLE } 3 \\
\text { DIA } \\
\text { (IN) }\end{array}$} & \multicolumn{2}{|c|}{ CRATER 1} & \multicolumn{2}{|c|}{ CRATER 2} & \multicolumn{2}{|c|}{ CRATER 3} \\
\hline & & & & & & & & & & & & $\begin{array}{l}\text { DIA } \\
\text { (IN) }\end{array}$ & $\begin{array}{l}\text { DEPIH } \\
\text { (IN) }\end{array}$ & $\begin{array}{l}\text { DIA } \\
\text { (IN) }\end{array}$ & $\begin{array}{l}\text { DEPTH } \\
\text { (IN) }\end{array}$ & $\begin{array}{l}\text { DIA } \\
\text { (IN) }\end{array}$ & $\begin{array}{l}\text { DEPTH } \\
\text { (IH) }\end{array}$ \\
\hline 769 & CAMERA-TI & 0.583 & 0.583 & YES & 1.31 & 32.81 & YES & 1.30 & 1.313 & & & 0.1 & 0.077 & 0.085 & 0.063 & 0.095 & 0.064 \\
\hline$\pi 71$ & STRESS & 0.688 & 0.76 & YES & 2.87 & 6.5 & nO & & 2.87 & & & & & & & & \\
\hline 772 & STRESS & 0.586 & 0.664 & YES & 1.15 & 21.65 & NO & & 1.15 & & & & & & & & \\
\hline 774 & STRESS & 0.628 & 0.786 & YES & 1.86 & 19.65 & nо & & 1.86 & & & & & & & & \\
\hline 919 & FL-1 & 0.838 & 1.019 & YES & 4.77 & 44.18 & No & & 4.77 & & & & & & & & \\
\hline 920 & $\mathrm{FL}-2$ & 0.86 & 0.98 & YES & 5.267 & 44.18 & nO & & 5.27 & & & & & & & & \\
\hline 894 & MLI-ON-B1 & 0.651 & 0.651 & YES & 1.84 & 6.54 & NO & & 1.84 & & & 0.075 & 0.016 & 0.136 & 0.051 & 0.094 & 0.035 \\
\hline 896 & MLI -ON-B2 & 0.738 & 0.738 & YES & 3.74 & 13.4 & MO & & 3.74 & & & 0.141 & 0.051 & 0.15 & 0.05 & 0.101 & 0.053 \\
\hline 897 & MLI-OW-B3 & 0.338 & 0.338 & YES & 0.301 & 7.07 & No & & 0.115 & 0.195 & 0.156 & 0.113 & 0.022 & 0.091 & 0.038 & 0.01 & 0.023 \\
\hline 898 & MLI-OH-B4 & 0.342 & 0.342 & NO & 0.342 & 5.64 & YES & 0.018 & & & & 0.097 & 0.092 & 0.101 & 0.053 & 0.166 & 9.097 \\
\hline 1150 & MLI -T-2 & 0.655 & 0.655 & YES & 0.774 & 12.56 & YES & 0.45 & 0.774 & & & & & & & & \\
\hline 859 & MLI - PURGE-1 & 0.692 & 0.692 & YES & 8.38 & 55.03 & No & & 8.38 & & & 0.206 & 0.07 & 0.146 & 0.065 & 0.048 & 0.077 \\
\hline 905 & $B L-A L-1$ & 0.674 & 0.674 & YES & 0.782 & 7.69 & No & & 0.782 & & & 0.082 & 0.024 & 0.084 & 0.02 & 0.073 & 0.01 \\
\hline 909 & $B L-A L-2$ & & & VES & 5.91 & 45.36 & NO & & 5.91 & & & & & & & & \\
\hline 734 & CAM-1 & 0.531 & 0.531 & YES & 0.517 & 15.9 & YES & 0.253 & 0.527 & & & 0.11 & 0.055 & 0.112 & 0.07 & 0.126 & 0.066 \\
\hline 735 & CAM-2 & 0.5 & 0.51 & No & & 10.99 & No & & & & & 0.125 & 0.076 & 0.104 & 0.108 & 0.122 & 0.062 \\
\hline 745 & EHSS-M1 & 0.73 & 0.73 & YES & 1.22 & 44.18 & No & & 1.22 & & & & & & & & \\
\hline 746 & EHSS-H2 & 0.682 & 0.852 & YES & 0.4 & 1 & No & & 0.4 & & & & & & & & \\
\hline 747 & EHSS-M3 & 0.647 & 0.647 & No & & 12.56 & no & & & & & 0.15 & 0.02 & 0.15 & 0.02 & 0.15 & 0.02 \\
\hline 756 & EHSS-M4 & 0.636 & 0.636 & YES & 0.8 & 31 & Nо & & 0.8 & & & & & & & & \\
\hline 736 & T5A & 0.656 & 0.688 & YES & 2.23 & 32.99 & YES & 9.74 & 2.23 & & & 0.1 & 0.126 & 0.106 & 0.058 & 0.075 & 0.092 \\
\hline 737 & 158 & 0.625 & 0.656 & YES & 2.19 & 38.29 & YES & 1.28 & 2.17 & 0.108 & 0.24 & 0.102 & 0.035 & 0.1 & 0.135 & 0.108 & 0.135 \\
\hline 738 & TSC & 0.656 & 0.656 & YES & 2.18 & 35.74 & YES & 1.47 & 2.16 & 0.23 & 0.138 & 0.1 & 0.125 & 0.097 & 0.071 & 0.075 & 0.075 \\
\hline 739 & T5D & 0.625 & 0.688 & YES & 2.47 & 28.27 & YES & 1.2 & 2.462 & 0.1163 & 0.075 & 0.17 & 0.108 & 0.102 & 0.076 & 0.063 & 0.042 \\
\hline 740 & TSE & 0.656 & 0.688 & YES & 11.5 & 103.67 & No & & & & & & & & & & \\
\hline 741 & TSF & 0.625 & 0.625 & YES & 7.5 & 43.98 & nO & & & & & & & & & & \\
\hline 742 & T5G & 0.625 & 0.625 & YES & 6.5 & 32.98 & NO & & & & & & & & & & \\
\hline 748 & T5H & 0.5 & 0.5 & YES & 0.12 & 6.87 & No & & 0.12 & & & 0.105 & 0.031 & 0.167 & 0.089 & 0.149 & 0.05 \\
\hline 749 & 151 & 0.531 & 0.563 & NO & & 7.66 & мо & & & & & & & & & & \\
\hline 750 & I5J & 0.469 & 0.469 & YES & 0.267 & 8.25 & NO & & 0.267 & & & 0.11 & 0.05 & 0.1 & 0.041 & 0.12 & 0.033 \\
\hline 751 & T5K & 0.469 & 0.5 & No & & 5.89 & No & & & & & 0.135 & 0.095 & 0.085 & 0.017 & 0.1 & 0.045 \\
\hline 752 & $T 5 L$ & 0.5 & 0.5 & No & & 7.66 & No & & & & & 0.063 & 0.03 & 0.075 & 0.024 & 0.086 & 0.02 \\
\hline 754 & TSM & 0.5 & 0.5 & NO & & 10.31 & No & & & & & 0.08 & 0.055 & 0.102 & 0.078 & 0.12 & 0.032 \\
\hline
\end{tabular}


SHOT nO. TEST nO.

BUMPER PLATE HOLE

BACKuALL BACKUALL EO (IN)

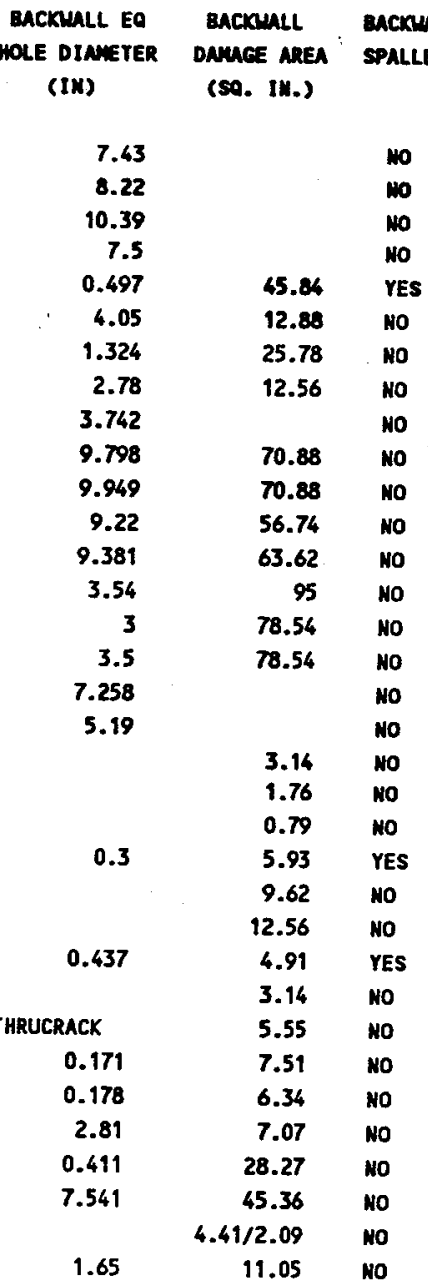

BACREALL

$\begin{array}{lccc}\text { HOLE } 1 & \text { HOLE } 2 & \text { HOLE } 3 & \text { CRATER } 1 \\ \text { DIA DIA } & \text { DIA } & \text { DIA }\end{array}$

(sa. III.)

(III)

(IN)

(IN)

(IN) (IN)

CRATER 2

DIA DEPTH

CRATER 3

\begin{tabular}{|c|c|c|c|c|}
\hline 906 & MGOI & 0.673 & 0.673 & YES \\
\hline 907 & MG02 & 0.671 & 0.671 & res \\
\hline $\begin{array}{l}912 \\
913\end{array}$ & $\begin{array}{l}\text { WG03 } \\
\text { WGO4 }\end{array}$ & $\begin{array}{l}0.665 \\
0.669\end{array}$ & $\begin{array}{l}0.665 \\
0.669\end{array}$ & $\begin{array}{l}\text { YES } \\
\text { YES }\end{array}$ \\
\hline 921 & HGO5 & 0.805 & 0.805 & YES \\
\hline 922 & WGO6 & 0.807 & 0.807 & YES \\
\hline 925 & HG07 & 0.621 & 0.973 & YES \\
\hline 926 & WG08 & 0.683 & 0.998 & YES \\
\hline 927 & 4609 & 0.673 & 0.997 & YES \\
\hline 887 & FP-01 & 0.687 & 0.687 & YES \\
\hline 892 & $\mathrm{FP}-02$ & 0.688 & 0.688 & YES \\
\hline 893 & fP-03 & 0.678 & 0.678 & YES \\
\hline 899 & FP-04 & 0.678 & 0.678 & YES \\
\hline 932 & FP- 5 & 0.656 & 0.656 & YES \\
\hline 933 & FP-6 & 0.656 & 0.656 & YES \\
\hline 934 & FP-7 & 0.656 & 0.656 & YES \\
\hline 937 & $F P-08$ & 0.878 & 0.878 & YES \\
\hline 938 & $F P-\infty Q$ & 0.868 & 0.868 & YES \\
\hline $\begin{array}{l}942 \\
946\end{array}$ & $\begin{array}{l}1001-B / F P-1 \\
1001-C / F P-1\end{array}$ & $\begin{array}{r}0.3125 \\
0.344\end{array}$ & $\begin{array}{c}0.3125 \\
0.344\end{array}$ & $\begin{array}{l}\text { No } \\
\text { No }\end{array}$ \\
\hline 947 & 1001-A/FP-1 & 0.25 & 0.25 & no \\
\hline 948 & $1002-B / F P-1$ & 0.4375 & 0.4375 & YES \\
\hline 950 & $1004-A / F P-1$ & 0.344 & 0.438 & no \\
\hline 951 & 1004-B/FP-1 & 0.375 & 0.438 & No \\
\hline 952 & 1002-A/EP-1 & 0.375 & 0.375 & YES \\
\hline 953 & $1002-C / F P-1$ & 0.468 & 0.468 & No \\
\hline 954 & $1005-\mathrm{A} / \mathrm{FP}-1$ & 0.5 & 0.656 & YES \\
\hline 955 & $1005-8 / F P-1$ & 0.656 & 0.688 & YES \\
\hline 957 & $1005-C / F P-2$ & 0.563 & 0.688 & YES \\
\hline 958 & $1003-A / F P-2$ & 0.5625 & 0.5625 & YES \\
\hline 1099 & 1003-B/FP-2 & 0.565 & 0.565 & YES \\
\hline 1100 & $1003-C / F P-2$ & 0.631 & 0.631 & YES \\
\hline 1101 & $1006-A / F P-2$ & 0.65 & 0.778 & NO/YES \\
\hline 1102 & $1006-B / F P-2$ & 0.654 & 0.86 & N \\
\hline
\end{tabular}

$\begin{array}{rrrr}7.43 & & \\ 8.22 & & \\ 10.39 & & \\ 7.5 & & \\ 0.262 & 0.25 & 0.162 \\ 4.05 & & \\ 0.841 & 0.899 & 0.252 \\ 2.78 & & \\ 9.798 & & \\ 9.949 & & \\ 9.22 & & \\ 9.381 & & \\ 3.54 & & \\ 3 & & \\ 3.5 & & \\ 7.258 & & \\ 5.19 & & \end{array}$

0.055

$\begin{array}{rrrrrr}0.16 & 0.053 & 0.14 & 0.022 & 0.19 & 0.023 \\ 0.154 & 0.03 & 0.121 & 0.034 & 0.14 & 0.026\end{array}$

$\begin{array}{llllll}0.23 & 0.037 & 0.236 & 0.054 & 0.11 & 0.012\end{array}$

$\begin{array}{llllllll}0.055 & 0.203 & 0.11 & 0.115 & 0.111 & 0.65 & 0.084 & 0.04 \\ & & 0.17 & 0.05 & 0.168 & 0.054 & 0.124 & 0.034\end{array}$

$\begin{array}{llllllll}0.16 & 0.437 & 0.06 & 0.034 & 0.073 & 0.031 & 0.084 & 0.013\end{array}$

$\begin{array}{llllll}0.246 & 0.029 & 0.073 & 0.044 & 0.069 & 0.012\end{array}$

$\begin{array}{llllll}0.1 & 0.125 & 0.073 & 0.057 & 0.09 & 0.049\end{array}$

$\begin{array}{lcccccc}0.171 & .311 / .311 & >0.125 & .236 / .145 & >.125 & .251 / .157 & 0.06\end{array}$

$\begin{array}{rrrrrrr}0.171 & 0.114 & 0.066 & 0.167 & 0.054 & 0.058 & 0.027 \\ 0.178 & 0.1 & 0.07 & 0.078 & 0.058 & 0.15 & 0.028\end{array}$

$\begin{array}{rrrrrrr}2.81 & 0.1 & 0.07 & 0.078 & 0.058 & 0.15 & 0.028 \\ 1.62 & 0.155 & 0.035 & 0.09 & 0.05 & 0.053 & 0.048\end{array}$

1.62

7.54

INLINE $=.64 \quad .276 / .276 \quad 0.113 / 0.113$

IMLINE $=.4 / .4$

DMISC.WK1 (Continued) 
